\title{
EVALUATION OF THE GEOTHERMAL RESOURCE IN THE AREA OF \\ ALBUQUERQUE, NEW MEXICO
}

George R. Jiracek

July 1983

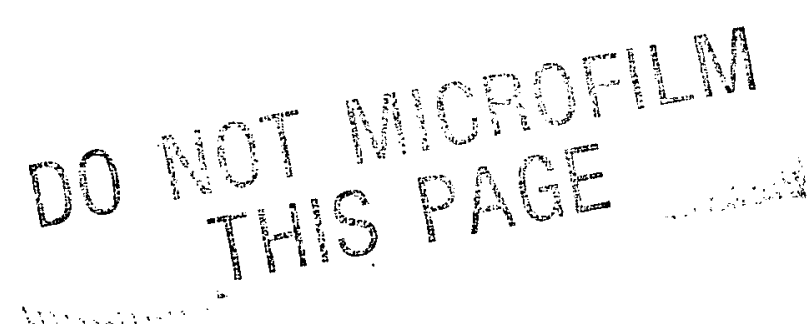

$\left(\frac{1}{6}\right.$

\section{MASTER}

New Mexico Energy Research and Development Institute 


\section{DISCLAIMER}

This report was prepared as an account of work sponsored by an agency of the United States Government. Neither the United States Government nor any agency Thereof, nor any of their employees, makes any warranty, express or implied, or assumes any legal liability or responsibility for the accuracy, completeness, or usefulness of any information, apparatus, product, or process disclosed, or represents that its use would not infringe privately owned rights. Reference herein to any specific commercial product, process, or service by trade name, trademark, manufacturer, or otherwise does not necessarily constitute or imply its endorsement, recommendation, or favoring by the United States Government or any agency thereof. The views and opinions of authors expressed herein do not necessarily state or reflect those of the United States Government or any agency thereof. 


\section{DISCLAIMER}

Portions of this document may be illegible in electronic image products. Images are produced from the best available original document. 


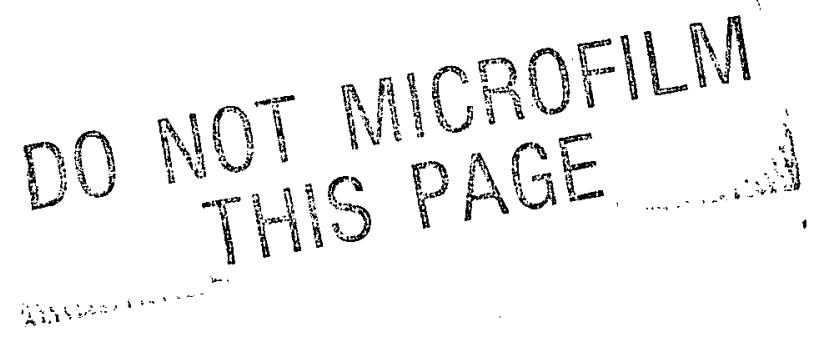

NOTICE

This report was sponsored by the State of New Mexico. Neither the State of New Mexico nor any agency thereof, nor any of their employees, makes any warranty, expressed or implied, or assumes any legal liability or responsibility for any third party's use of the results of such information, apparatus, product or process disclosed in this report, or represents that its use by such third party would not infringe privately owned rights.

The New Mexico Energy Research and Development Program is funded by the New Mexico State Legislature and is administered by the New Mexico Energy Research and Development Institute, Pinon Building, Room 358, 1220 South St. Francis Drive, Santa Fe, New Mexico 87501. 


\title{
EVALUATION \\ OF THE
}

GEOTHERMAL RESOURCE

IN THE AREA OF

ALBUQUERQUE, NEW MEXICO

\author{
George R. Jiracek \\ Department of Geological Sciences \\ San Diego State University \\ San Diego, California 92182-0337 \\ Chandler A. Swanberg \\ Departments of Physics/Earth Sciences \\ New Mexico State University \\ Las Cruces, New Mexico 88003 \\ Paul Morgan \\ Lunar and Planetary Institute \\ 3303 NASA Road 1 \\ Houston, Texas 77058 \\ Mark D. Parker \\ Law Engineering Testing Company \\ 2749 Delk Road, SE \\ Marietta, Georgia 30067 \\ July 1983
}

The work from which this material is drawn was conducted with the support of the New Mexico Energy and Minerals Department. However, the authors remain solely responsible for the content of this material.

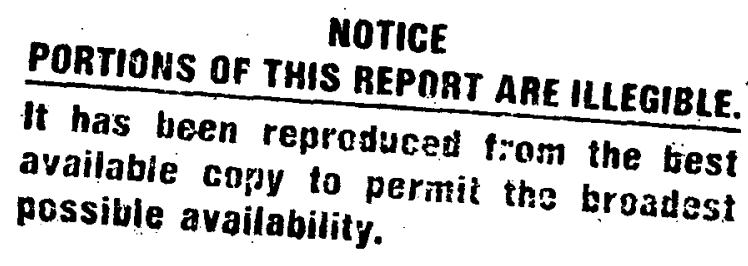

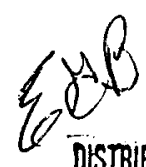

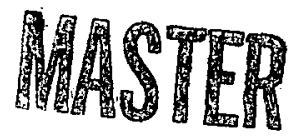

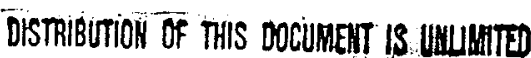


BIBLICORAPGIC DATA SFIEFT

for reports sponsored by the

New Mexico Energy Research and Development Institute

Santa Fe, NM 87501

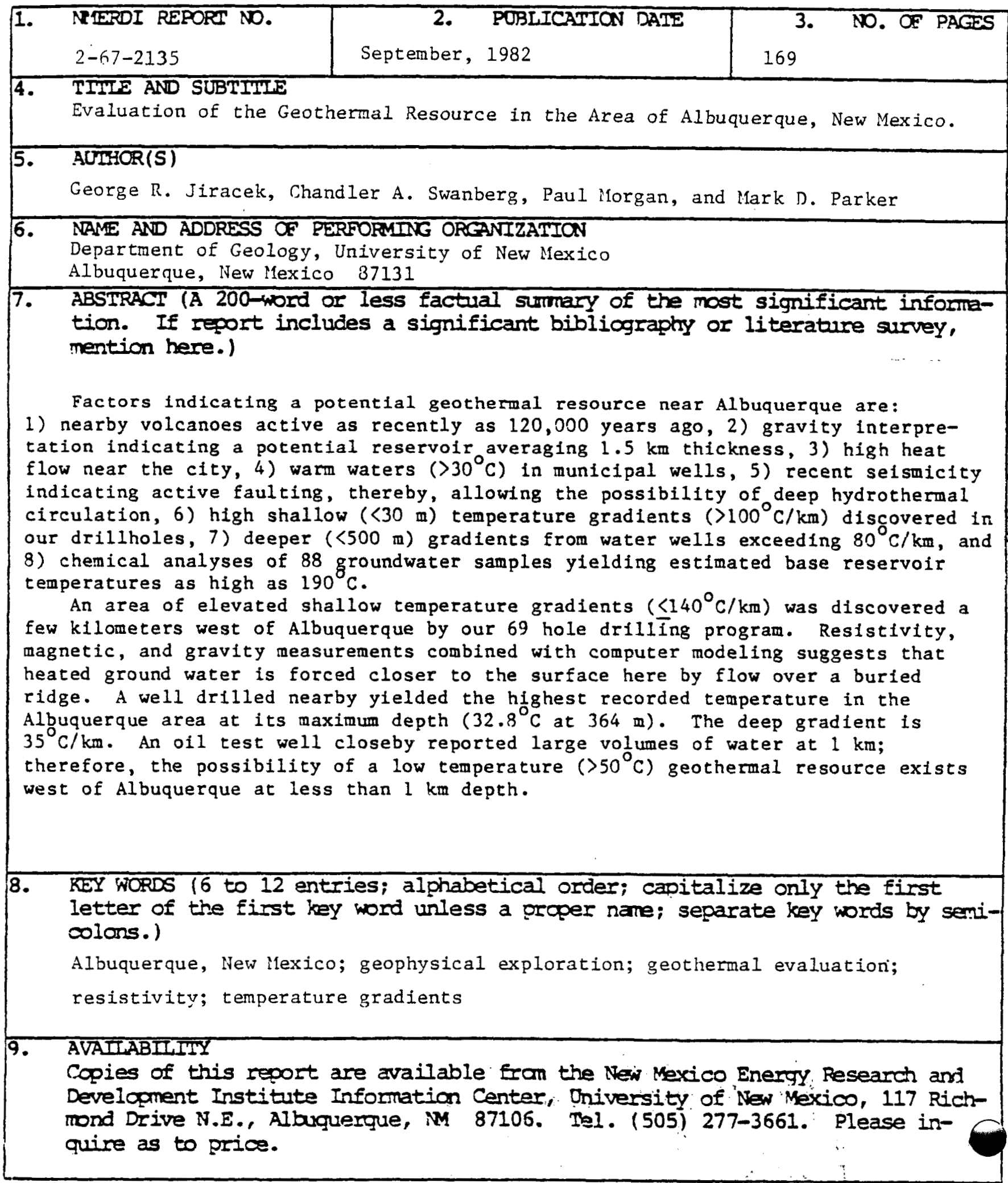




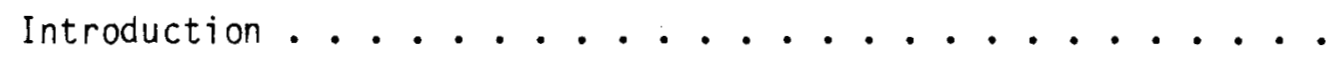

Geologic Setting . . . . . . . . . . . . . . . .

Hydrology. . . . . . . . . . . . . . . . . . .

Geothermal Occurrences .................

Regional Geophysical Studies

Introduction ..................... 23

Gravity. . . . . . . . . . . . . . . . . 24

Seismicity... . . . . . . . . . . . . . . . 30

Thermal

Heat Flow................ . . . . 35

Bottom Hole Temperatures. . . . . . . . . 35

Temperature Logging - Available Wells . . . . . . . 46

Temperature Logging - Drilled Holes . . . . . . . 55

Geothermometry ................ . . 59

Resistivity Methods in Geothermal Exploration. . . . . . . 65

Llano De Atrisco Anomaly

Introduction ........................... 74

Temperature Gradient Survey. . . . . . . . . . . . 78

Resistivity Measurements . . . . . . . . . . 81

Magnetic Survey. . . . . . . . . . . . . . . 93

Conclusions. . . . . . . . . . . . . . . 98

References . . . . . . . . . . . . . . . 104 Appendices

A. Shallow Temperature Gradient Measurements in the

Albuquerque Area. . . . . . . . . . . .

B. Geochemical Temperatures and Chemical Data for Ground

Waters in the Albuquerque Area........... 


\section{LIST OF ILLUSTRATIONS}

Figure 1. Tectonic map of upper Rio Grande rift area near

Page

Albuquerque (from Hiss et al., 1975) ........

Figure 2. West-east structure sections across Albuquerque basin (from Kelley, 1977)............... 6

Figure 3. Tectonic map showing faults mapped in Albuquerque basin near Albuquerque (from Kelley, 1977) . . . . . 8

Figure 4. Location of volcanic features in the Albuquerque basin. Basin border marked by hatchured line; cones and vents located by solid black spots (from Kelley and Kudo, 1978).

Figure 5. Schematic diagram of geohydrologic regimes in Rio Grande rift near Albuquerque (from Hiss et al., 1975) .... .

Figure 6. Water-table elevation map (in feet) in Albuquerque area (after Bjorklund and Maxwe11, 1961)........ 16

Figure 7. Possible geothermal occurrences in Albuquerque area:

a) conductive thermal refraction and $b$ ) thermal ground-water convection along basin bounding fault (from Blackwell and Chapman, 1977) ..........

Figure 8. Hypothetical Rio Grande rift forced ground-water

convection system and expected surface heat flow
profile. Relative temperatures in arbitrary units
indicated in circles (from Morgan and Daggett, 1981).

convection system and expected surface heat flow
profile. Relative temperatures in arbitrary units
indicated in circles (from Morgan and Daggett, 1981).

convection system and expected surface heat flow
profile. Relative temperatures in arbitrary units
indicated in circles (from Morgan and Daggett, 1981)...

Figure 9. Distribution of point sources of pressure used to model uplift from hypothesized magma bodies at $19 \mathrm{~km}$ depth between Socorro and Albuquerque (from Reilinger et al., 1980). . . . . . . . . . . . . .

Figure 10. Complete Bouguer anomaly gravity map of Albuquerque basin (from Cordell et a?., 1973) and locations of profiles modeled by Birch $(1980,1982) \ldots . . .$.

Figure 11. Modeled gravity profile 2 passing through Shell-Santa Fe Pacific No. 1 (S\#1 SFP) oil test well. Circles mark density layer interfaces $\left(\mathrm{g} / \mathrm{cm}^{3}\right)$ inferred from well data (from Birch, 1980; 1982) ........... 
Figure 12. Modeled gravity profile 1 passing through Carpenter No. 1 Atrisco (C\#1A) oil test well. Circles mark density layer interfaces $\left(\mathrm{g} / \mathrm{cm}^{3}\right)$ inferred from well data (from Birch, 1980; 1982) ..............

Figure 13. Thickness of $2.20 \mathrm{~g} / \mathrm{cm}^{3}$ low density fill in Albuquerque basin calculated by gravity modeling (from Birch 1980, 1982). . . . . . . . . . . . . . .

Figure 14. Map of microearthquake area near Albuquerque volcanoes (from Jaksha et al., 1981) ............ 32

Figure 15. Map of epicenters of microearthquakes (left) and section with earthquake focal depths (right) near Albuquerque volcanoes (from Jaksha et al., 1981) ........ 33

Figure 16. $0 i 1$ and gas well bottom hole temperature data near Albuquerque. . . . . . . . . . . . . .

Figure 17. Location map showing oil and gas wells yielding bottom hole temperature data near Albuquerque (base map from Kelley and Kudo, 1978) ...............

Figure 18. Water well bottom hole temperature data in Albuquerque: C4, L4, VA3, VA4, VA5, VC1, VC3, WM2, and W1 are Charles \#4, Love \#4, Vol-Andia \#3, \#4, \#5, Volcano Cliffs \#1, \#3, West Mesa \#2, and Walker \#1 wells, respectively .................. 4 43

Figure 19. Location map showing Albuquerque municipal water well fields indicating thermal gradients over $40^{\circ} \mathrm{C} / \mathrm{km}$. . .

Figure 20. Location map showing 25 water wells (triangles) and 8 commercial driliholes (circles), exclusive of the Llano de Atrisco, which were temperature logged in Albuquerque area .....................

Figure 21. Temperature versus depth in water wells in Albuquerque with depths of less than $100 \mathrm{~m}$...........

Figure 22. Temperature versus depth in water wells of greater than $100 \mathrm{~m}$ depth in the inner Rio Grande valley and East mesa areas of Albuquerque . . . . . . . . . . . 
Figure 23. Temperature versus depth in water wells of greater than $100 \mathrm{~m}$ depth on the West mesa and Llano de Atrisco areas of Albuquerque . . . . . . . . . . . .

Figure 24. Location map of West mesa and Llano de Atrisco showing 8 holes (A1 - A8) drilled in 1978 by New Mexico State University . . . . . . . . . . . . . . .

Figure 25. Location map of Albuquerque area, Bernalillo County showing locations of ground waters used for geochemical analyses . . . . . . . . . . . . . .

Figure 26. Location map of Albuquerque area, Bernalillo County showing heat flow data. Numbers near dots are traditional heat flow values (Reiter et al., 1975). Numbers in blocks are silica predicted heat flow values. Heat flow values in HFU. . . . . . . . . . 64

Figure 27. Schematic of possible hydrothermal target and corresponding resistivity model. . . . . . . . 66

Figure 28. Use of resistivity in hydrothermal exploration . . . • 68 Figure 29. Resistivity techniques and common arrays . . . . . . 70 Figure 30 . Common collinear resistivity arrays. . . . . . . . 70

Figure 31 . Common areal resistivity arrays. . . . . . . . . 72

Figure 32. Pseudosection method of plotting dipole-dipole apparent resistivity results. . . . . . . . . . . 72

Figure 33. Base map of Llano de Atrisco area west of Albuquerque. RS and $B$ are radar site and Benavides water wells; C1A is Carpenter \#1 Atrisco oil test well. Faults after Kelley (1977)................. . .

Figure 34. Shallow temperature gradient map of Llano de Atrisco in Albuquerque area. Contours in ${ }^{\mathrm{O}} \mathrm{C} / \mathrm{km}$.........

Figure 35. Shallow temperatures measured in test holes located on Line 0 , Stations $5 \mathrm{~W}$ and $6 \mathrm{~W}$ of Llano de Atrisco....

Figure 36. Observed and calculated Schlumberger sounding S2 - $78^{\circ}$ on Llano de Atrisco in Albuquerque area and interpreted eight-layer resistivity model. . . . . . . . . 82 
Figure 37. Observed and calculated Schlumberger sounding $53-90^{\circ}$ on Llano de Atrisco in Albuquerque area and interpreted eleven-layer resistivity model . . . . . . . . .

Figure 38. Observed total field apparent resistivity map derived from NS BDI transmitter on Llano de Atrisco in Albuquerque area . . . . . . . . . . 85

Figure 39. Calculated BD1 total field apparent resistivity map derived from layered earth estimated from Schlumberger S2 and equatorial $\$ 3-90^{\circ}$ results .........

Figure 40. Observed total field apparent resistivity map derived from NS BD2 transmitter on Llano de Atrisco in Albuquerque area............. . .

Figure 41. Calculated BD2 total field apparent resistivity map derived from layered earth estimated from Schlumberger $\mathrm{S} 2$ and equatorial $\mathrm{S} 3-90^{\circ}$ results ..........

Figure 42. Observed and calculated dipole-dipole DD1 pseudosections and calculated two-dimensional resistivity model along Line 0 of Llano de Atrisco in Albuquerque area . . .

Figure 43. Observed and calculated dipole-dipole DD2 pseudosections and calculated two-dimensional resistivity model along Line $1.75 \mathrm{~N}$ of Llano de Atrisco in Albuquerque area . .

Figure 44. Total magnetic field map of Llano de Atrisco in Albuquerque area. Contours in nanoteslas. . . . . . 94

Figure 45. Magnetic prism model . . . . . . . . . . . . 96

Figure 46. Calculated magnetic anomaly crossed on Line $4 \mathrm{~N}$ of Llano de Atrisco in Albuquerque area. Hatchured area is plan view of prism body .. . . . . . . . . 9 96

Figure 47. Complete Bouguer gravity map of Liano de Atrisco in Albuquerque area. Contours in milligals (after Birch, 1980; 1982). . . . . . . . . . . .

Figure 48. Profiles of shallow thermal gradient, magnetic, gravity, and resistivity surveys on Llano de Atrisco in Albuquerque area............... 100 
Page

Table 1. Generalized section of geologic formations in the Albuquerque area including water-bearing characteristics (from Bjorklund and Maxwel1, 1961) ......... 14

Table 2. Summary of heat flow data near Albuqueruqe, New Mexico (from Reiter et al., 1975) ........... 36

Table 3. $0 i 1$ and gas well bottom hole temperatures and thermal gradients near Albuquerque, New Mexico . . . . . . 37

Table 4. Water well bottom hole temperatures and thermal gradients in Albuquerque, New Mexico . . . . . . . 41

Appendix A

Table 1a. Geochemical temperatures for ground waters in the Albuquerque area. Data from this report . . . . 152

Table 1b. Geochemical temperatures for ground waters in the Albuquerque area. Data from USGS WATSTORE file. • 153

Table 1c. Geochemical temperatures for ground waters in the Albuquerque area. Data from the City of Albuquerque 155

Table 2a. Chemical data for ground waters in the Albuquerque area. Data from this report ......... 161

Table 2b. Chemical data for ground waters in the Albuquerque area. Data from USGS WATSTORE file. . . . . 162

Table 2c. Chemical data for ground waters in the Albuquerque area. Data from the City of Albuquerque ...... 164 


\section{ACKNOWLEDGMENTS}

The breadth of the investigations undertaken to evaluate the geothermal potential in the area of Albuquerque required the cooperation of numerous organizations and individuals as well as the able assistance of many students. Students from the University of New Mexico were J. Coney, E. Dunn, S. Ganoe, M. Gerety, M. Herman, T. Holcombe, B. Honea, C. Hudson, R. Lawrence, M. Mahoney, S. Raeuchle, T. Summers, Jr., M. Vaughn, R. Wasserman, and C. Zimmeman. E. Gustafson from San Diego State University and J. Gilkey, A. Hooker, R. Montman, and D. Stokes from New Mexico State University also helped in the data collection and interpretation.

Access to various properties on the west side of Albuquerque was graciously provided by A. Candelaria of Westland Development Company, F. Bond of Volcano Ranch, the City of Albuquerque Parks Department, A. Smrcka of the University of Albuquerque, A. Brown of Top Brand Western Land Company, and landowners G. Bennett and F. Meggers. Commercial drilling operations were arranged through W. Turner of American Groundwater Consultants and utilized drillrigs operated by $C$. White and $J$. Garner from the Grants, New Mexico area. The city of Albuquerque Water Resources Department, in particular D. MacRae and his staff, and Chief Martinez of the Fire Department, permitted our entrance into city water wells and the usage of fire hydrant water for drilling purposes, respectively. 
Many beneficial discussions were held with F. S. Birch of the University of New Hampshire while he was on sabbatical leave at the University of New Mexico, J. Callender of the University of New Mexico, A. Ramo of Sunoco Energy Development Company, G. Hammock and J. Sorell of Gordon Herkenhoff and Associates, D. Wilkins, B. Scott, S. Anderholm, and J. Hudson at the U. S. Geological Survey Water Resources Division in Albuquerque, L. Jaksha of the U. S. Geological Survey Seismological Laboratory in Albuquerque, B. Grant, Jr. of Energy Resources Exploration, and $k$. Hatton of the State of New Mexico Energy and Minerals Department in Santa Fe. A. P. Shaw, III, a consulting geologist in Albuquerque, geologically logged the U.S. Geological Survey's water monitor wells. Water chemical analyses were performed by A. Bristol and his staff at the Soil and Water Testing Laboratory, Department of Agronomy, New Mexico State University. Two Geometrics G-816 magnetometers loaned to us by Sandia Laboratories aided our operation. We also wish to thank E. Strawn, S. Fenby, C. Peterson, and L. Hunt who assisted in the preparation of the manuscript at San Diego State University.

The work presented in this report was funded by New Mexico Energy and Minerals Department Grant No. 78-2135, New Mexico Energy Institute/ Department of Energy Subcontracts Nos. 1-4-23406-X1 and X2, and U. S. Geological Survey Contract No. 14-08-0001-17879. 


\section{INTRODUCTION}

The energy future of New Mexico depends heavily on utilization in the Albuquerque area, where roughly one-third of the State's one million plus inhabitants reside. Albuquerque is situated within the Albuquerque basin, the largest of several deep, fault-controlled basins which comprise the Rio Grande rift, a structure with recognized geothermal resources. Although there are no hot springs or hot wells in the immediate vicinity of the city, the proximity of young volcanoes, warm temperatures in nearby water and oil wells, and high heat flow to the west of the city suggest the presence of geothemal fluids in the basin.

A summary of the factors which indicate a potential geothermal resource in or near Albuquerque are:

1) A group of fissure-controlled basaltic volcanoes, active as recently as 120,000 years before present (Machette, 1978), are within Albuquerque's city limits and form its western skyline. Other young volcanoes and magnetic indications of subsurface igneous bodies dot the Albuquerque basin.

2) Available gravity maps (Cordell et al., 1978) show the Albuquerque basin to be very deep and extensively faulted. Gravity modeling by Birch $(1980,1982)$ places the average depth of high porosity, water saturated rift fill at $1.5 \mathrm{~km}$. Such fill, which locally exceeds $2.5 \mathrm{~km}$ in thickness, provides an excellent geothermal reservoir. 
3) A band of elevated heat flow (averaging about $\left.105 \mathrm{~mW} / \mathrm{m}^{2} ; 2.5 \mathrm{HFU} ; 1 \mathrm{HFU}=1 \mu \mathrm{cal} / \mathrm{cm}^{2} / \mathrm{sec}\right)$ trends north-south to the west of the Rio Grande (Reiter et al., 1975). A locally high value of $130 \mathrm{~mW} / \mathrm{m}^{2}$ (3.1 HFU) was obtained in the Rio Puerco valley, $35 \mathrm{~km}$ west of Albuquerque.

4) Anomalously warm waters $\left(32^{\circ} \mathrm{C}\right)$ have been reported issuing from Albuquerque's municipal West Mesa well field (e.g. Summers, 1976).

5) The U. S. Geological Survey Seismology Laboratory in Albuquerque (Jaksha et al., 1981) detected microseismic activity about $3 \mathrm{~km}$ west of the Albuquerque volcanoes. The swarm activity resulted in about 300 earthquakes between September, 1978 and April, 1979. The average focal depth of the microearthquake sequence was calculated to be $9.5 \mathrm{~km}$. Contemporary seismic activity provides evidence that fault zones are active and may be available as conduits for or control deep hydrothermal circulation.

6) Anomalously high shallow $(<30 \mathrm{~m})$, temperature gradients $\left(>100^{\circ} \mathrm{C} / \mathrm{km}\right)$ were discovered by our drilling program west of the city. The high values are localized in a region having a background gradient of about $60^{\circ} \mathrm{C} / \mathrm{km}$ in the shallow subsurface.

7) Deeper gradients $(<500 \mathrm{~m})$ measured in isolated water wells have exceeded $80^{\circ} \mathrm{C} / \mathrm{km}$ compared to the estimated deep background gradient of about $30^{\circ} \mathrm{C} / \mathrm{km}$.

8) Eighty-eight ground-water samples analyzed by silica and alkali geothermometer methods yielded estimated base reservoir temperatures as high as $190^{\circ} \mathrm{C}$.

The first phase of our investigation was to assimilate current knowledge of the area's geology, hydrology, and geophysics. A complete account of all of these data sets would fill many volumes. The current report provides brief sumaries of the most pertinent results. 
This report mainly emphasizes and details the new results obtained by our program. Our original proposal described a program of low cost reconnaissance and high cost detailing possibly leading to follow-up exploration. Low cost data acquisition consisted of geochemistry on nearly ninety water samples and thermal gradient measurements in twenty-five existing water wells. Supplementary ground magnetic surveying was utilized instead of additional gravity collection as initially planned. High cost detailing combined a thermal gradient drilling program with deep electrical resistivity investigations. The discovery of anomalously high shallow temperature gradients west of Albuquerque during our initial drilling program and fortuitous drilling economics led to the drilling of sixty-nine gradient holes rather than the five to ten boreholes originally proposed. Results of the temperature gradient, resistivity, magnetic, and gravity results west of Albuquerque have al ready been described by Parker and Jiracek (1980), Jiracek (1982), and Jiracek et al. (1982). Regional gravity calculations bearing on the lateral and depth extent of possible geothermal reservoirs were published by Birch (1980, 1982).

This report includes results obtained under Grant No. 78-2135 from the New Mexico Energy and Minerals Department and Department of Energy/New Mexico Energy Institute Subcontract No.1-4-23406. A U. S. Geological Survey Water Resources Division Contract (No. 14-08-000117879) provided additional support extending the field program. 


\section{GEOLOGIC SETTING}

Albuquerque lies in the Albuquerque basin (also called the Albuquerque-Belen basin), in the central Rio Grande rift (Figure 1). The basin is approximately $160 \mathrm{~km}$ long and up to $60 \mathrm{~km}$ wide and is one of a long line of basins which collectively form the Rio Grande rift. Details of the geology of the basin have been given by Kelley (1977).

Figure 1 from Hiss et al. (1975) illustrates the major tectonic aspects of the Albuquerque basin. The basin is bordered on the east by the dramatic Manzano and Sandia uplifts which are tilted blocks dipping eastward. The western margin of the basin is more variable with the Lucero uplift, the Puerco fault zone, and the southern end of the Nacimiento uplift forming a much more subdued border.

The structural cross-sections located in Figure 1 and shown in Figure 2 illustrate the deeply faulted nature of the basin and the bounding uplifts. Whether or not the normal faults are steeply dipping over their entire depth extent, as shown in Figure 2, or decrease in dip with depth (so-called listric faulting) has been the source of some controversy (Russell, 1978; Brown et al., 1980). From our standpoint it is only important that the faults penetrate to sufficient depth so that deep basin circulation of water may result in elevated temperatures near-surface.

More than $2.5 \mathrm{~km}$ of Tertiary clastic sediments, mostly composed of sands, silts, and gravels, fill the central basin depression $\left(T_{s}\right.$ in Figure 2). Locally this material may exceed over $3 \mathrm{~km}$ thickness as established by deep oil test wells in the basin (Birch, 1980; 1982). 


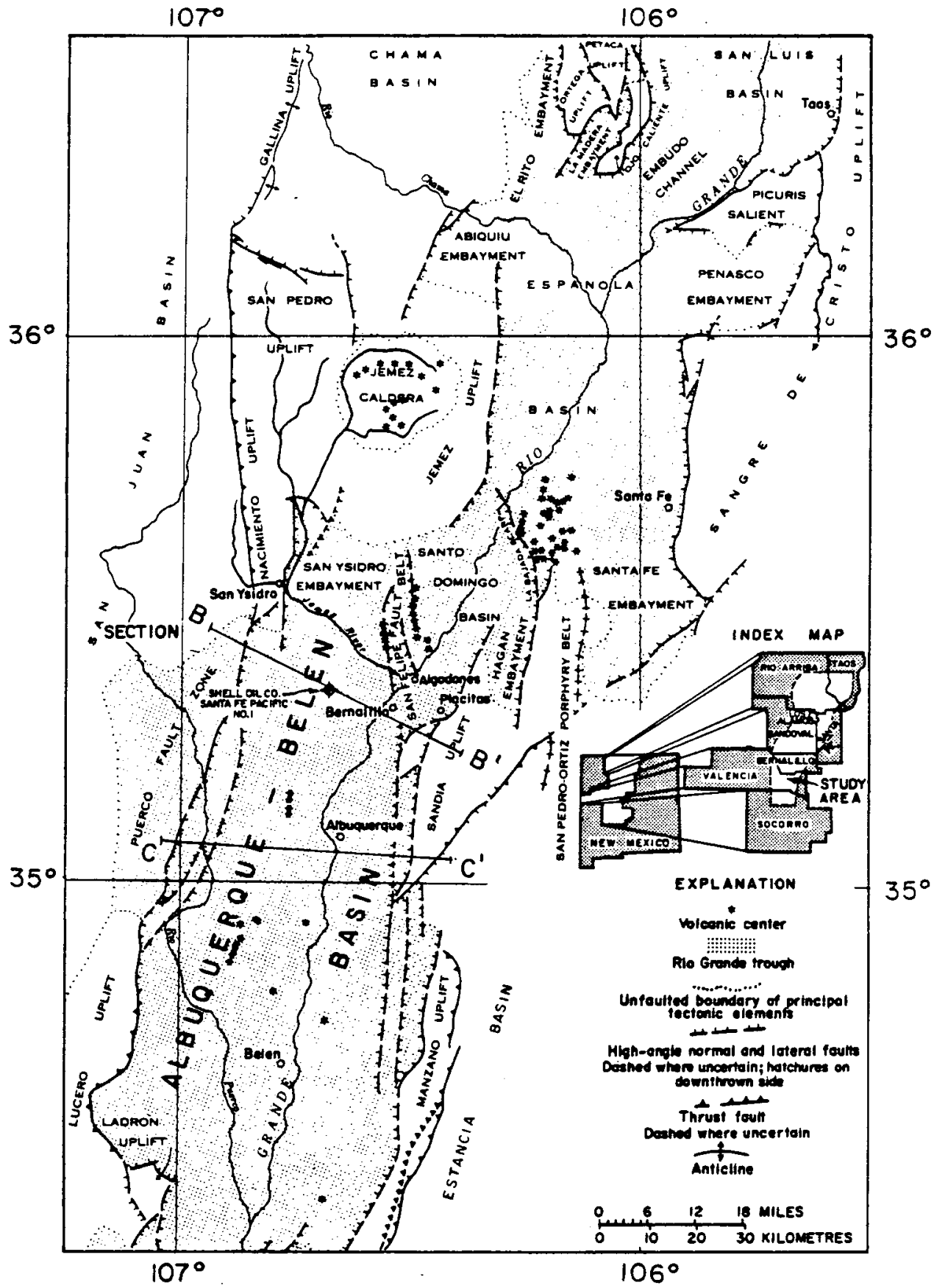

Figure 1. Tectonic map of upper Rio Grande rift area near Albuquerque (from Hiss et al., 1975). 

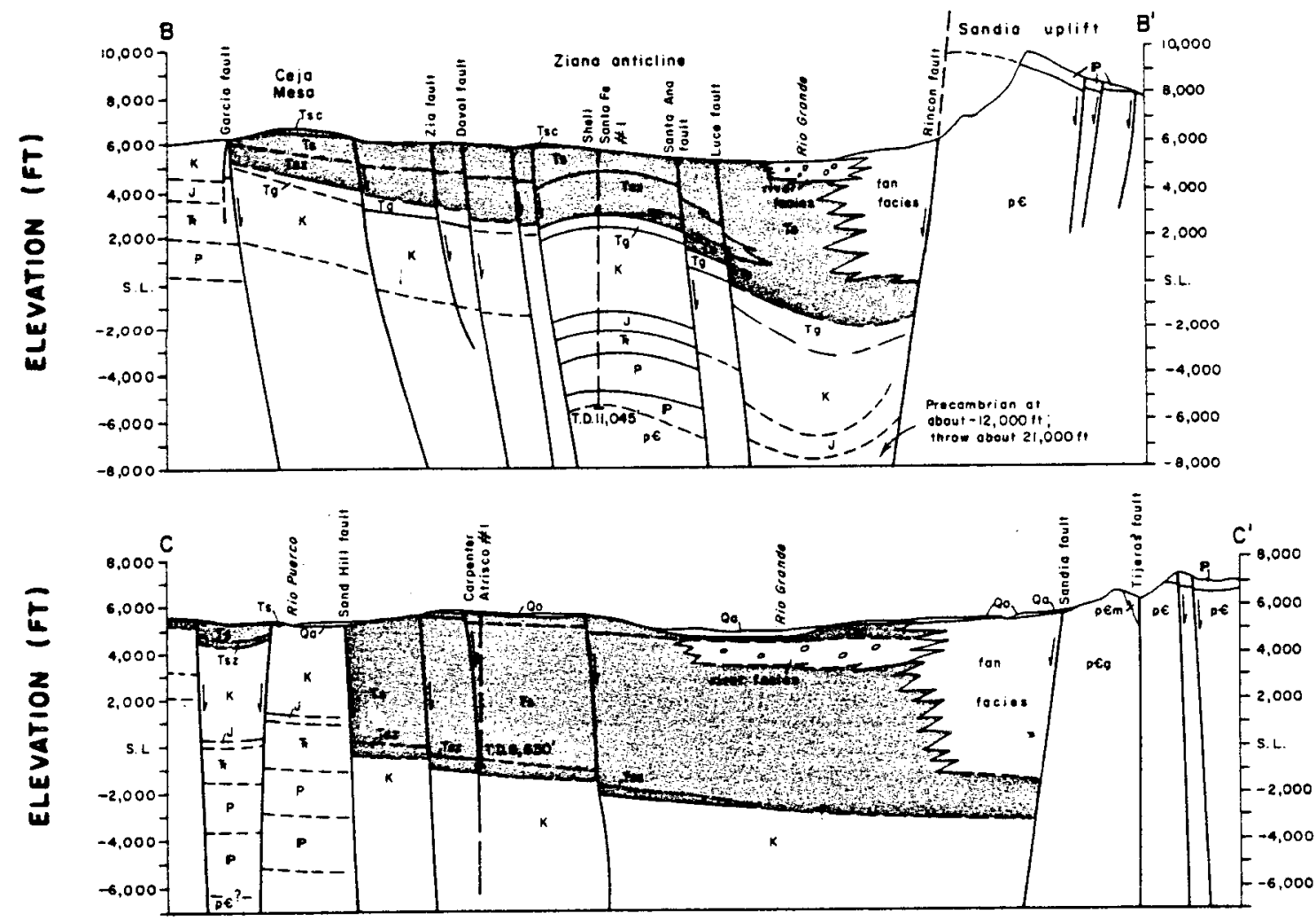

SCALE :

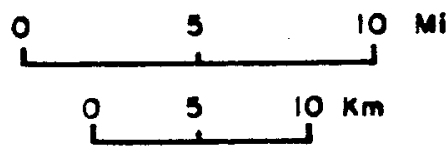

Figure 2. West-east structure sections across Albuquerque basin (from Kelley, 1977). 
The basin fill is saturated with water below the water table and generally yields large quantities of water of good quality (Bjorklund and Maxwe11, 1961). It is, therefore, a prime candidate for a deep, vast storage reservoir for geothermal waters.

Because of very active late Cenozoic geomorphic processes in the Albuquerque basin, very few faults have a surface expression within the depression itself (Figure 3). The uplifted blocks (e.g. Sandia uplift) and the Puerco fault belt are intensely faulted (Figure 3), hence similar disruption is expected in the basement rocks as hypothesized in the sections of Figure 2. Kelley (1977) delineated the position of the major gravity inflection on either side of the rift (Figure 3 ); this provides a method of inferring the location of buried faults, which can be undertaken by gravity modeling, as described in the subsequent Gravity section.

Numerous young volcanic centers (Figure 4), 0.12 - 3.0 million years in age (Bachman and Mehnert, 1978; Machette, 1978; Kelley and Kudo, 1978; Kudo, 1982), are located along the west bounding faults of the Albuquerque basin. These have extruded significant volumes of mainly basaltic lava which cover, or interfinger with, the basin sediments. The oldest volcanic feature in the Albuquerque basin is Black Butte (Figure 4). Dated to be 24.3 million years old (Bachman and Mehnert, 1978), this andesitic occurrence is typical of the early rift volcanism (Kudo, 1982). The north-south alignment of the Cat Hills, Wind Mesa, Albuquerque, and the San Felipe fields appears to mark a structural flaw in the Albuquerque basin. The olivine tholeiite basalt at the Albuquerque volcanoes could have differentiated at depths less than 24 km; however, the alkali basalts at Cat Hills, Isleta, and Wind Mesa 


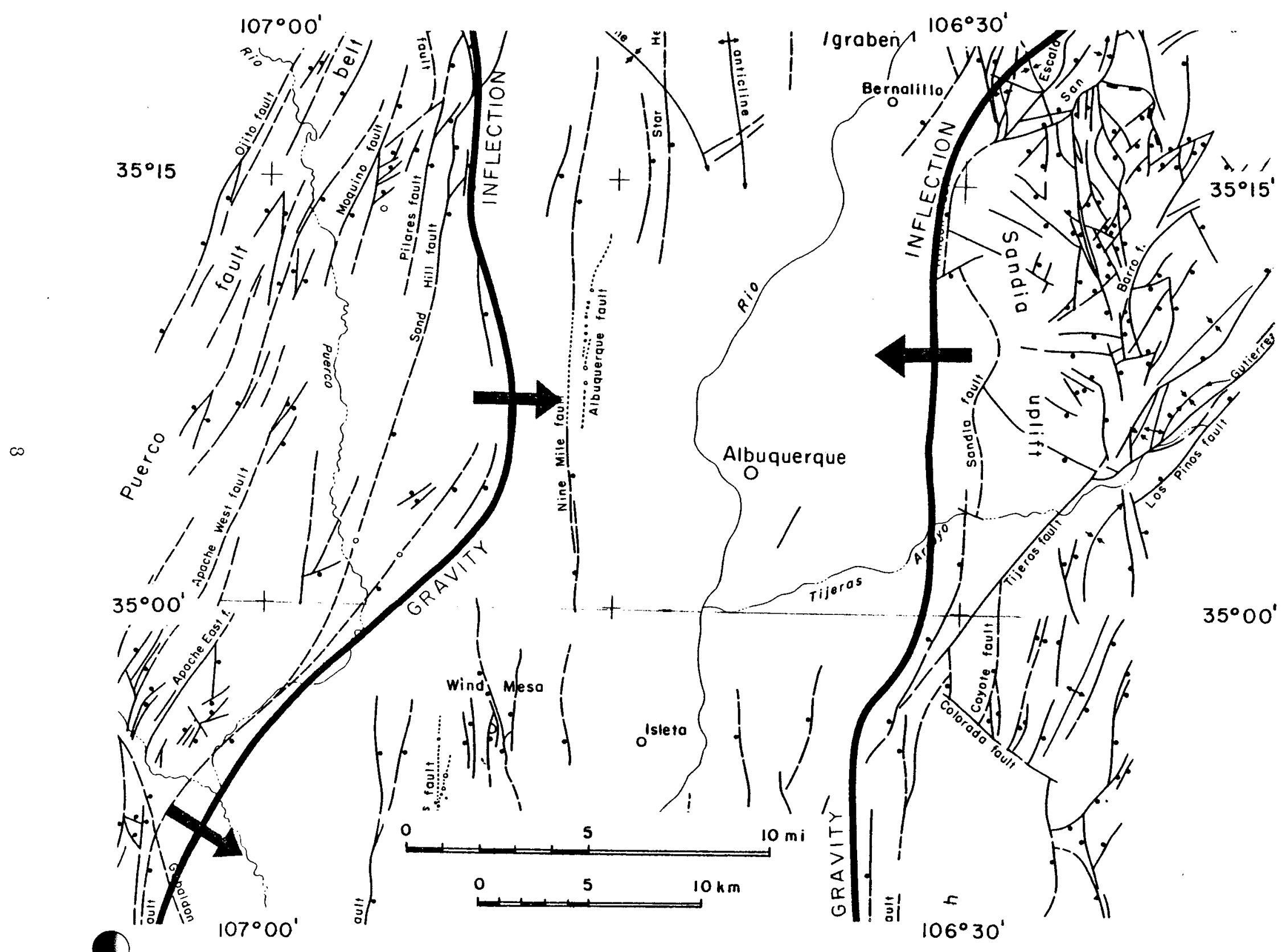




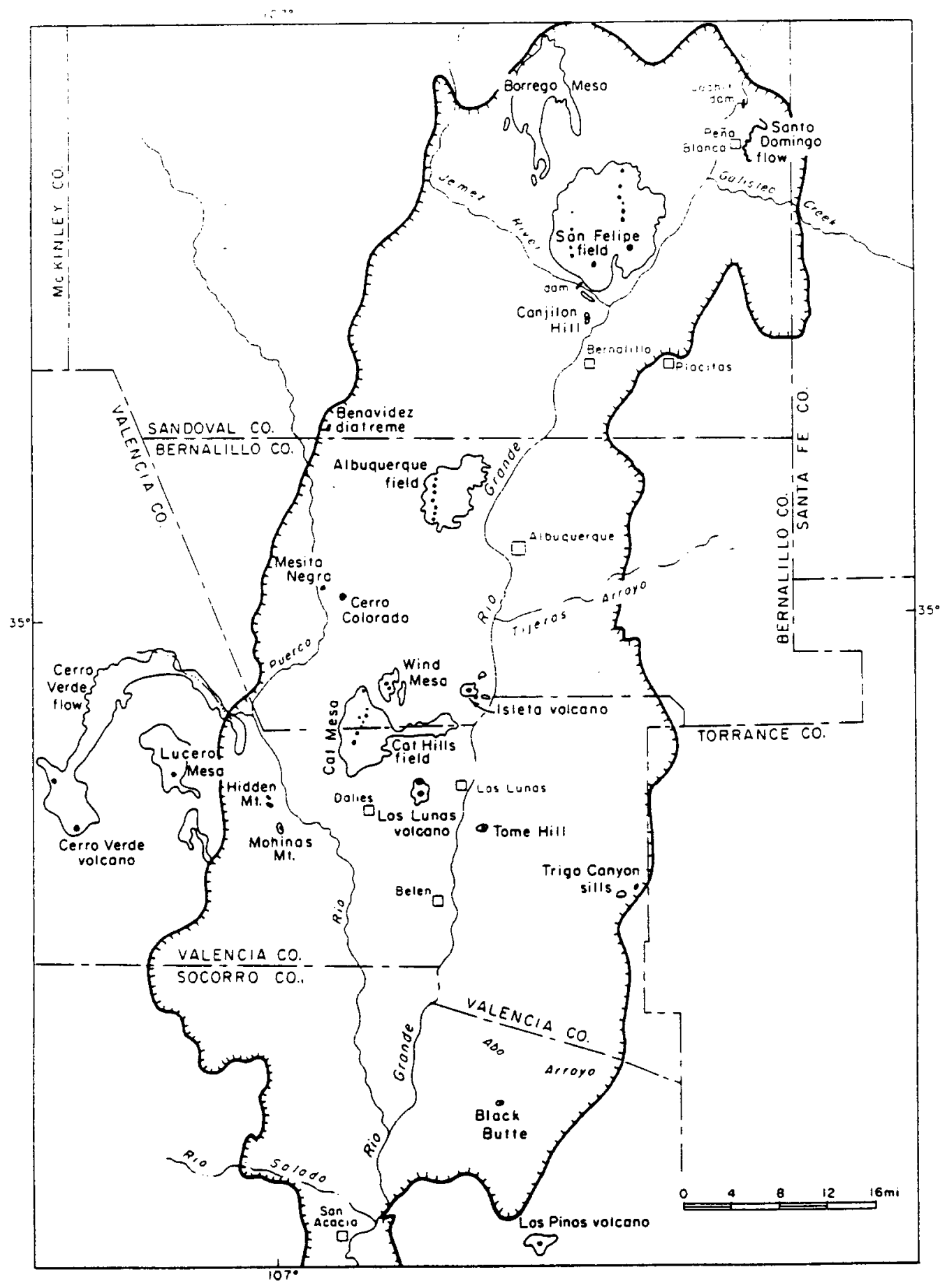

Figure 4. Location of volcanic features in the Albuquerque basin. Basin border marked by hatchured line; cones and vents located by solid black spots (from Kelley and Kudo, 1978). 
indicate deeper tapping of mantle magma (Kelley and Kudo, 1978; Kudo, 1982). Andesitic centers at Los Lunas, Tome Hill, and Black Butte (Figure 4) are estimated to have shallower crustal origin, perhaps under hydrous conditions (Kasten, 1977; Kelley and Kudo, 1978; Kudo, 1982). The fact that volcanism has been active episodically for three million years raises the possibility that small, secondary magma heat sources may reside at shallow crustal depths. Such plutons with areal extents of roughly one $\mathrm{km}^{2}$ are thought to exist at 4 to $10 \mathrm{~km}$ depth in the Socorro area (Chapin et a1., 1978).

A final geologic feature bearing on the geothermal aspects of the Albuquerque area is the evidence (Callender and Zilinski, 1976) of a "fossil" geothemal system along the Lucero uplift (Figure 1). Detailed geologic mapping (Zilinski, 1976) of spring deposits has established at least four periods of hot and cold-spring activity in the last two million years. The present springs are cold but a geothermal component may be mixed in the discharging waters (Trainer and Lyford, 1979). Riddle and Grant (1981) and Grant (1982) have described extensive travertine deposits mapped even nearer to Albuquerque on the eastern side of the basin, on Kirtland Air Force Base. Most of these deposits are not associated with present day springs but their depositional character suggests spring origin. 


\section{HYDROLOGY}

Since natural occurring underground water is the obvious heat transfer medium for geothermal exploitation in the Albuquerque area, its characterization is an ultimate goal. Characteristics such as the depths, thicknesses, specific yields, recharge sources, salinities, pressure conditions, and temperatures of all aquifers are clearly desirable. The U. S. Geological Survey, Water Resources Division in Albuquerque is a major source of information regarding the occurrence, quantity, quality, distribution, and movement of surface and underground waters in the area. Publications by Bjorklund and Maxwell (1961), Reeder et al. (1967), Hiss et al. (1975), and Wright (1978) are a few of the key reports orginating from this group. A further update of the hydrologic characteristics of the Albuquerque area will be included in the U. S. Geological Survey's program reports on the Southwest Alluvial Basins Project (D. Wilkins, personal communications, 1979-1982). Other sources of water-resource information in the Albuquerque area are the New Mexico State Engineers Office in Santa Fe, the U. S. Army Corps of Engineers Office in Albuquerque, and the City of Albuquerque, Department of Water Resources. In addition, Gordon Herkenhoff and Associates, Inc., in Albuquerque supervise most of the drilling of Albuquerque's municipal water wells and have provided us with much current information. A history of the ground-water use in the Albuquerque area has recently been presented by Kelly (1982). 
This section of our report briefly describes the general hydrologic resource in the Albuquerque area. The city of Albuquerque is centrally located in the $160 \mathrm{~km}$ long Albuquerque basin (Figure 1). The area is drained by the Rio Grande system. The extent of the vast subsurface water supply associated with this system can be appreciated by considering the simplified west-east block diagram in Figure 5 . Table 1 contains the generalized geologic formations in the Albuquerque area and their water-bearing characteristics. Alluvium of Recent age underlies the flood plain of the inner Rio Grande valley. This is a very shallow source of water with some wells yielding as much as 3,000 gal/min (189.2 1/sec) (Bjorklund and Maxwel1, 1961).

The Santa Fe group (Formation) underlies the surficial deposits in the Rio Grande valley and crops out on the East and West mesas (Figure 5). It is by far the most productive aquifer in the Albuquerque area and is the source of most municipal and industrial water. Gravity interpretations (to be described later in the Gravity section) yield an average thickness of Santa Fe sediments of about $1.5 \mathrm{~km}$ beneath most of the city of Albuquerque. The pumped yield of eighty-three large Albuquerque water wells producing in the Santa Fe ranged from 240 to $2,200 \mathrm{gal} / \mathrm{min}$ (15.1 to $138.8 \mathrm{l} / \mathrm{sec}$ ) and averaged $860 \mathrm{gal} / \mathrm{min}(54.2$ 1/sec). Possible deeper aquifers occur in the Mesozoic and older formations. For example, the San Andres limestone of Permian age has yielded as much as 3,000 gal/min (189.2 1/sec) near Grants, New Mexico from fracture and solution-channel permeability (Kelly et al., 1974). Very little quantitative data are known about the ground water in the deeper aquifers in the Albuquerque basin. Some water quality data have been reported from the $3,339 \mathrm{~m}$ deep Santa Fe Pacific No. 1 oil test 

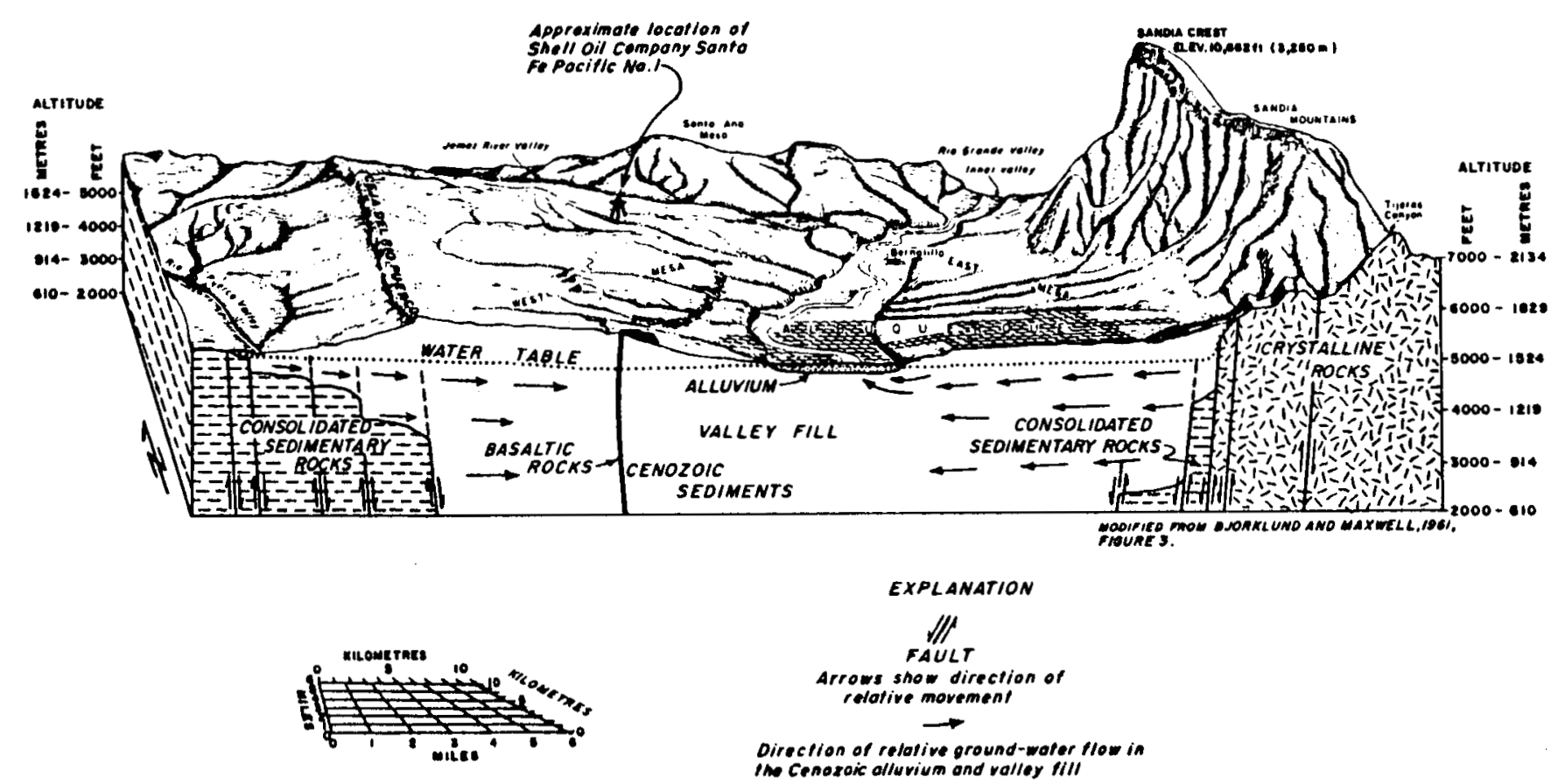

Figure 5. Schematic diagram of geohydrologic regimes in Rio Grande rift near Albuquerque (from Hiss et al., 1975). 
GENERALIZED SECTION OF GEOLOGIC FORMATIONS

IN THE ALBUQUERQUE AREA INCLUDING WATER-BEARING

CHARACTERISTICS

(From Bjorklund and Maxwe11, 1961)

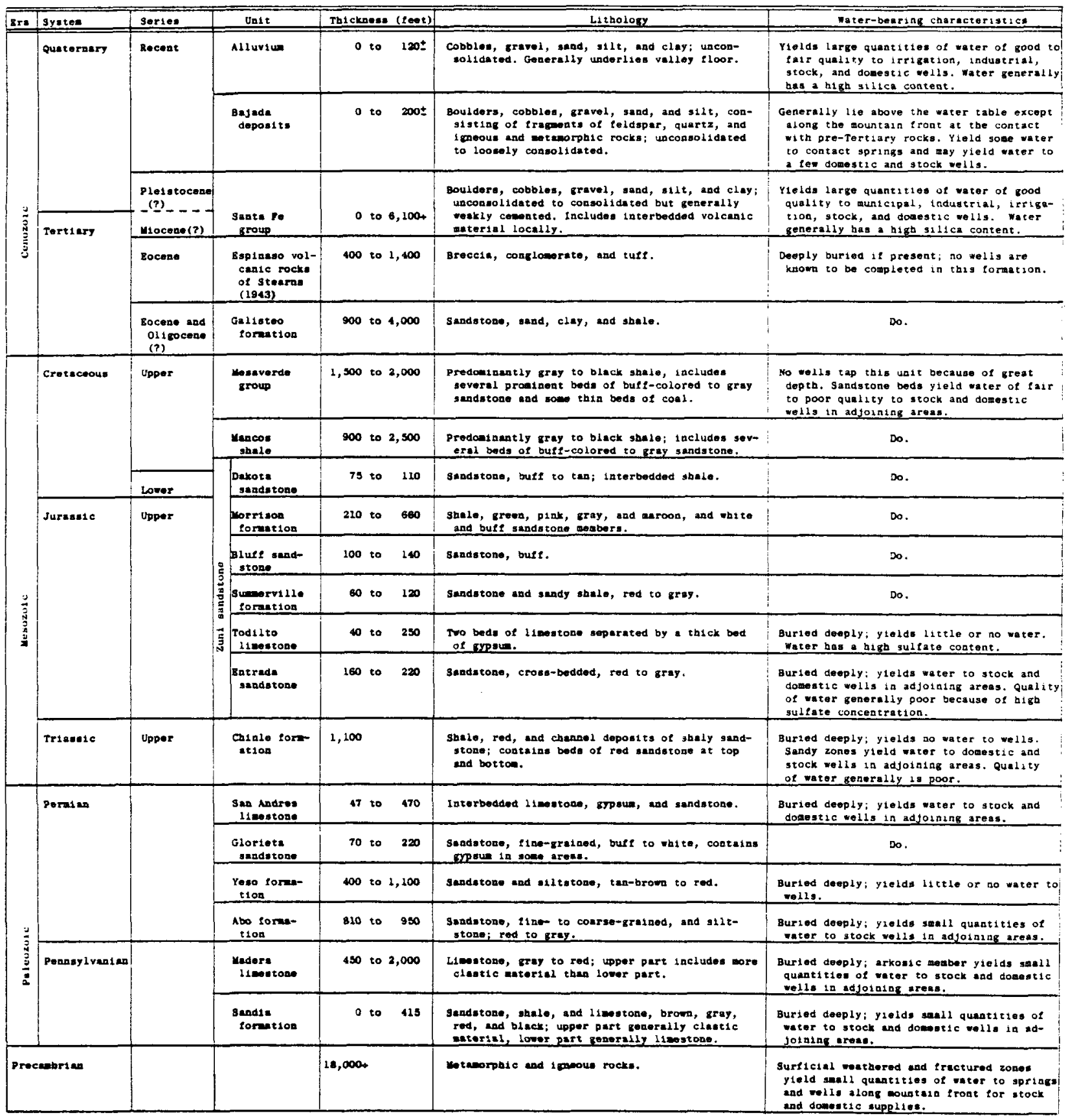


well drilled about $30 \mathrm{~km}$ north-northwest of Albuquerque (Hiss et al., 1975). Water was recovered from potential aquifers ranging from the shallowest sample $(472 \mathrm{~m})$ in the Santa Fe Formation to a deeper one in the Yeso Formation at 2,863 m depth (Table 1). The total dissolved solids in the deeper formation were measured between $3,300-9,680 \mathrm{mg} / 1$. Measurements in the Santa Fe Formation ranged from 868 to $1,570 \mathrm{mg} / 1$. Hiss et a1. (1975) infer that the upper fresh-water zone may be a relatively thin lens only 150 to $245 \mathrm{~m}$ thick in this part of the Albuquerque basin. Water quality generally deteriorates below this lens with some minor interfingering of fresh and saline waters below, e.g. salinity of water was calculated to be only $500 \mathrm{mg} / \mathrm{l}$ at about $260 \mathrm{~m}$ depth.

Hiss et al. (1975) listed sources from which the ground water in the Albuquerque basin is derived: 1) precipitation within the lowland part of the basin; 2) underflow from the Rio Grande valley upstream from the basin, and infiltration from the Rio Grande; 3) inflow from the Jemez uplift, to the north (Figure 1); 4) inflow from outside the trough, from both the east and west. Figure 5 shows arrows representative of ground-water flow due to the latter source.

Figure 6 shows the water table contours in the Albuquerque area as given by Bjorklund and Maxwell (1961). The U. S. Geological Survey has updated this map using additional control data (D. Wilkins, personal communications, 1981); however, the major patterns remain unchanged. The slope of the water table beneath the inner valley (Figure 5) is essentially the same as the downstream slope of the Rio Grande; this slope is approximately $1.1 \mathrm{~m} / \mathrm{km}$ near Albuquerque (Hiss et al., 1975). On the East mesa the water table slopes generally southwestward from the 


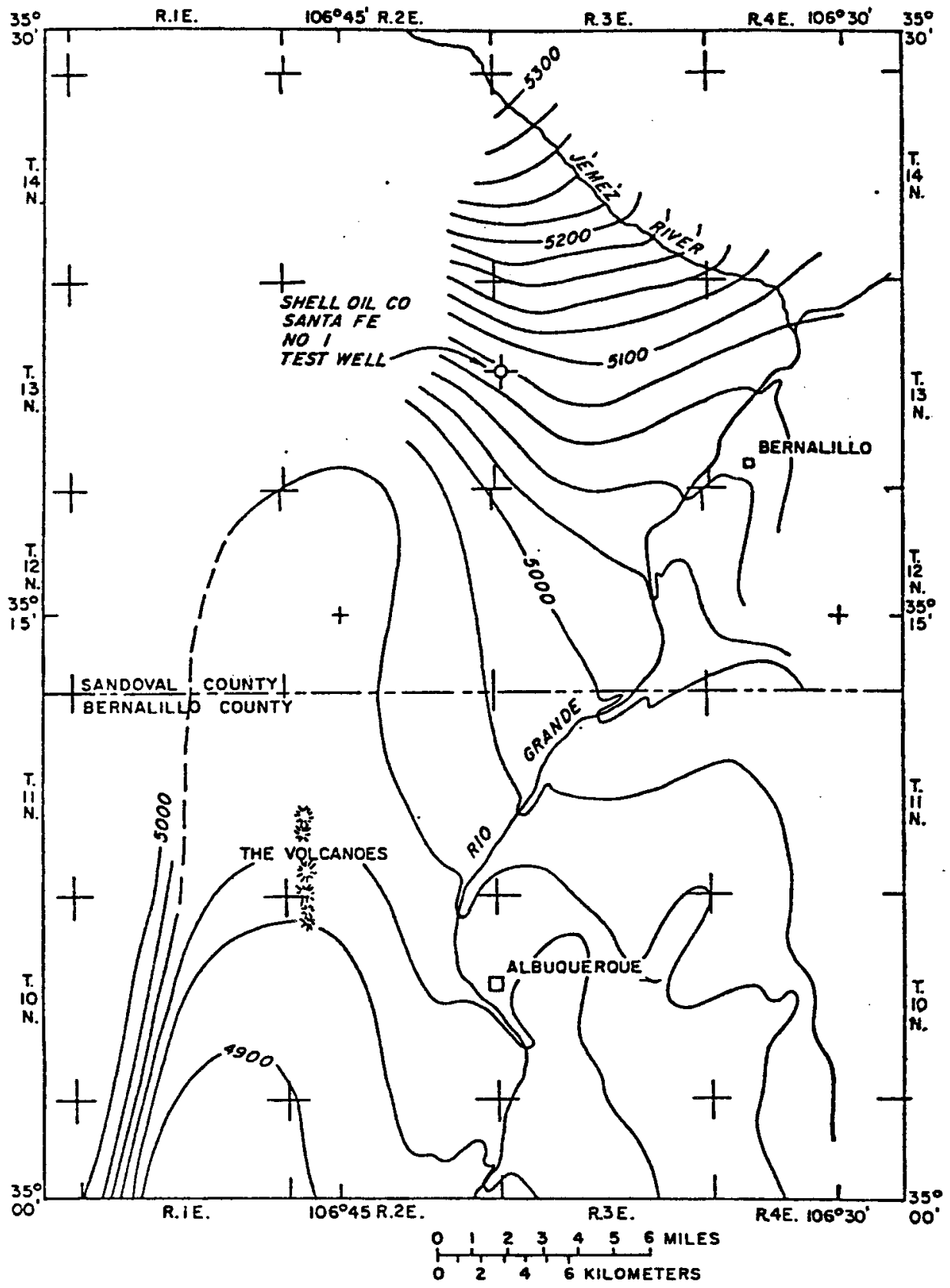

Figure 6. Water-table elevation map (in feet) in Albuquerque area (after Bjorkl und and Maxwell, 1961). 
Sandia Mountains (Figure 5) at a rate of about 1 to $4 \mathrm{~m} / \mathrm{km}$ (Bjorklund and Maxwel1, 1961); however, this gentle gradient is proceeded by an abrupt water level change where water crosses the bounding rift faults (Titus, 1963). This is illustrated on the east side of Figure 5 where water moving to the west from the Sandia Mountains cascades abruptly to a lower level into the permeable sediments of the Santa Fe Formation. The water table on the West mesa slopes eastward from the Rio Puerco valley. The steep gradient (as much as $10 \mathrm{~m} / \mathrm{km}$ ) is thought to be due to less permeable, finer-grain water-bearing materials ( $D$. Wilkins, personal communications, 1981).

A broad, linear downwarp or trough in the water table, extending southward from the Jemez River, through Bernalillo County, into Valencia County is evident west of Albuquerque (Figure 6). The lowest part of the trough is over $10 \mathrm{~m}$ below the Rio Grande; it is approximately 10 to $15 \mathrm{~km}$ wide to the west of the city. Several causes for this trough have been proposed (Bjorklund and Maxwell, 1961) and are still being debated. Pumped water well temperatures in Albuquerque range from 11 to $32^{\circ} \mathrm{C}$ (Bjorklund and Maxwell, 1961). The warmest well was that of municipal West Mesa well \#l which was drilled to a depth of $360 \mathrm{~m}$ in 1960 . The $32^{\circ} \mathrm{C}$ water still represents the highest pumped temperature in a city water well despite many additional wells, some drilled near the Albuquerque volcanoes. A report on the geothermal resources in New Mexico by Stone and Mizell (1977) lists only the West Mesa well in Albuquerque and three other wells (Tome, Isleta, and Mesita) south of Albuquerque as being warm $\left(>30^{\circ} \mathrm{C}\right)$. The Tome well was listed earlier by 
Summers (1976) as having $80^{\circ} \mathrm{C}$ water in a $219 \mathrm{~m}$ well. Efforts to locate this well south of Albuquerque as listed revealed that the positioning of this well in Bernalillo County was incorrect. It is actually in Valencia County much farther south. Although the Tome well was never field checked in our work, we believe that the $80^{\circ} \mathrm{C}$ listed is a typographical error; it should be $80^{\circ} \mathrm{F}$. Many temperature measurements were made in deep water wells and shallow boreholes in the course of our study. These are reported upon in detail in later sections.

GEOTHERMAL OCCURRENCES

Expected geothermal occurrences in the Albuquerque area can be classified according to the four mechanisms for producing thermal anomalies discussed by Harder et al. (1980). These are namely:

1) conductive thermal refraction, 2) thermal ground-water convection, 3) forced ground-water convection, and 4) igneous intrusion.

Conductive thermal refraction occurs at a basin margin and is due to the contrast in themal conductivity between bedrock and valley fill. This effect is illustrated in Figure $7 a$, following the work of Blackwell and Chapman (1977), where increased heat flow is evident over the bedrock adjacent to the basin. Spacing of the isotherms in Figure $7 \mathrm{a}$ show that higher geothermal gradients are present over the margins of the valley fill. In considering the refraction hypothesis for the Rio Grande rift, Harder et al. (1980) conclude that it may explain a portion of the regional thermal anomaly but it can not explain the observed local anomalies.

Blackwell and Chapman (1977) have also studied the effects of thermal convection (water circulation) along basin bounding faults 

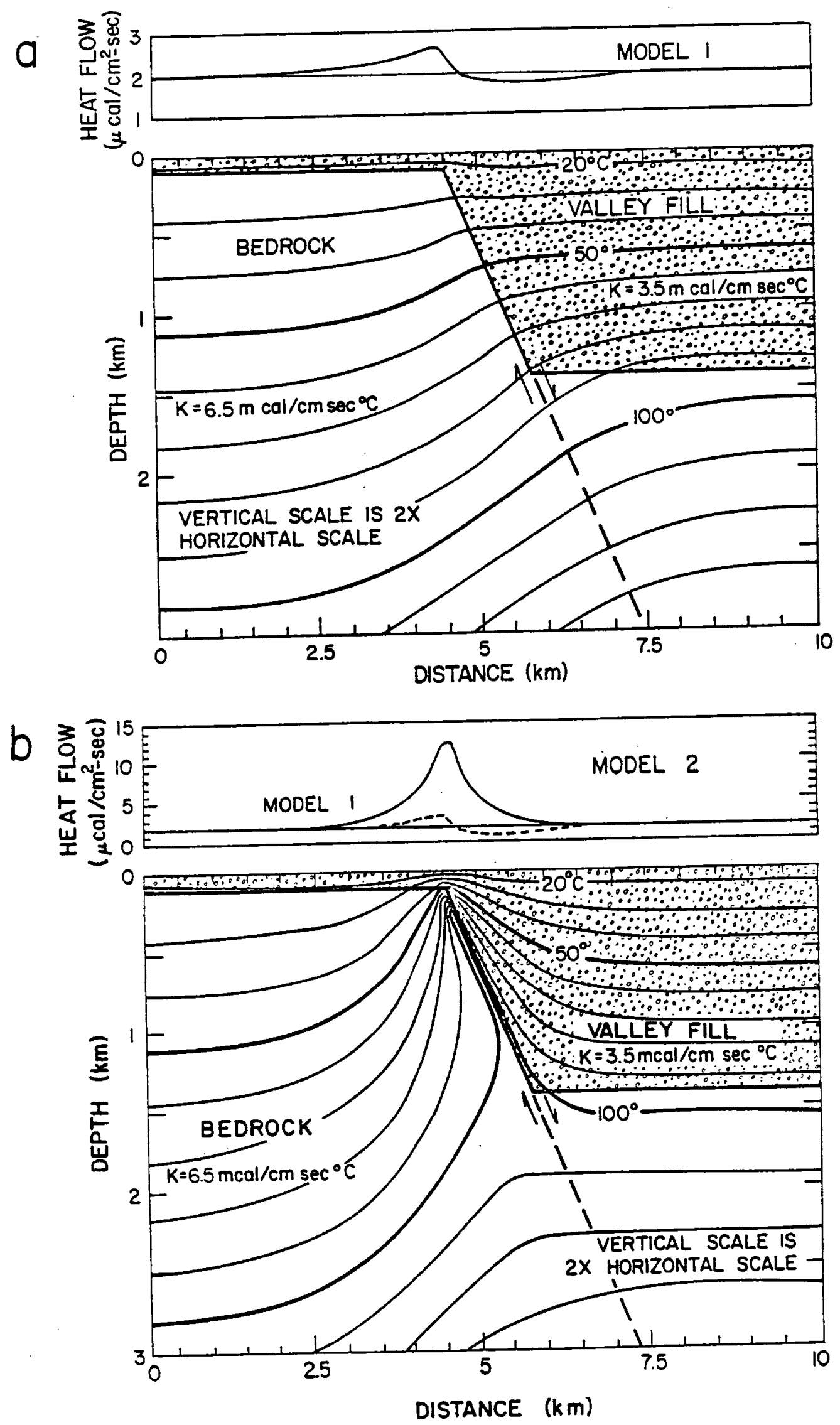

Figure 7. Possible geothermal occurrences in Albuquerque area: a) conductive thermal refraction and b) thermal ground-water convection along basin bounding fault (from Blackwell and Chapman, 1977). 
(Figure 7b). The differences between refraction and thermal convection are clearly shown in Figure $7 b$ where the highest geothermal gradients would be located directly over a convecting fault zone. Convection is a much more effective heat transfer mechanism than conduction, hence, large heat flow anomalies can be obtained. For example, heat flow as high as $490 \mathrm{~mW} / \mathrm{m}^{2}$ (11.7 HFU) has been reported in the Socorro area where thermal convection probably dominates (Reiter and Smith, 1977). The question of the possible initiation of thermal convection along a fault zone has been discussed by Harder et al. (1980). They cite theoretical studies which indicated that such convection is unlikely at thermal gradients less than $50^{\circ} \mathrm{C} / \mathrm{km}$; therefore, it would not occur at normal Rio Grande rift gradients $\left(\sim 30^{\circ} \mathrm{C} / \mathrm{km}\right)$.

Since typical geothermal gradients are deemed insufficient to drive thermal convection in the Rio Grande rift, Harder et al. (1980) considered forced ground-water convection as the most common source of rift geothermal anomalies. This mechanism has been elaborated on by Morgan and Daggett (1981) and by Morgan et al. (1981) and is schematically depicted in Figure 8. In this model, heated ground water from depth is brought closer to the surface by hydraulically forced flow over subsurface constrictions or barriers. Lower maximum temperatures are expected in this situation compared to thermal convection (Figure 7b). This is so because water may circulate into the basement in a thermal convection system; temperature in the forced convection system is limited by the maximum depth of water circulation in the basin.

The presence of a crustal magma heat source would, of course, provide considerable energy for increased thermal conduction and convection. Harder et al. (1980) have estimated that shallow intrusives 


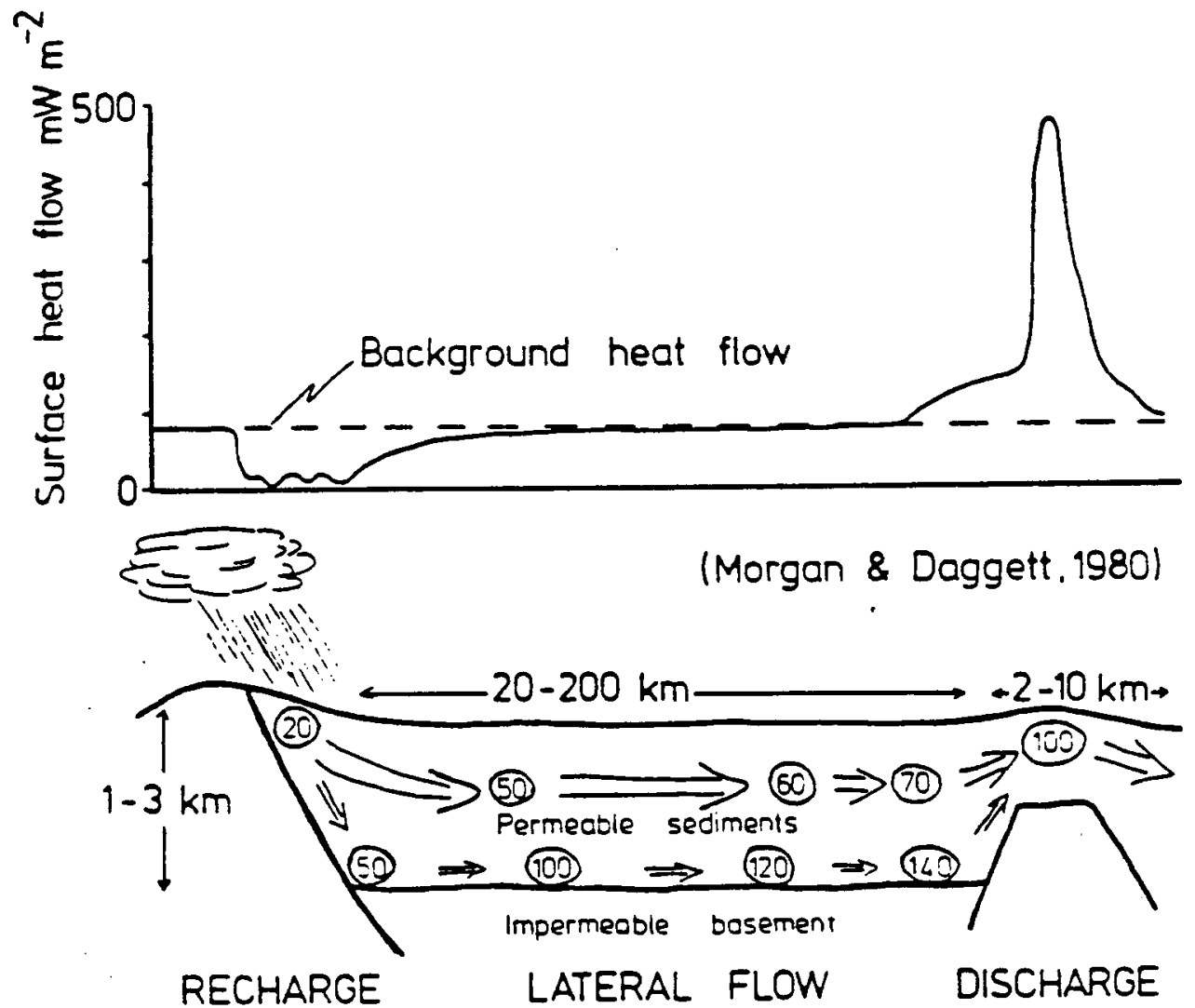

Figure 8. Hypothetical Rio Grande rift forced ground-water convection system and expected surface heat flow profile. Relative temperatures in arbitrary units indicated in circles (from Morgan and Daggett, 1981).

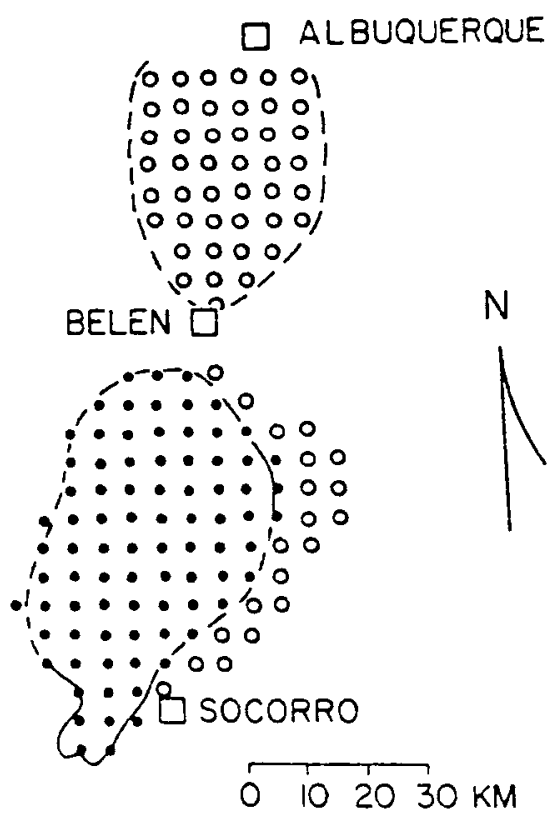

Figure 9. Distribution of point sources of pressure used to model uplift from hypothesized magma bodies at $19 \mathrm{~km}$ depth between Socorro and Albuquerque (from Reilinger et al., 1980). 
(1 - $2 \mathrm{~km}$ depth) of modest volumes $\left(\sim 100 \mathrm{~km}^{3}\right)$ would have to be less than 50,000 years old to be major factors in producing Rio Grande rift geothermal anomalies. The youngest volcanic date in the Albuquerque area is 140,000 years at the Cat Hills volcanic field (Kelley and Kudo, 1978) although Machette (1978) estimated that the Albuquerque volcanoes have been episodically active from 200,000 to 120,000 years before present. The youngest volcanoes are basaltic in composition so that it is unlikely that their magma chambers were (are) at shallow crustal levels. Consequently, young, shallow magma intrusion does not seem a likely possibility for geothemal anomalies in the Albuquerque area. Considerable discussion has been generated regarding the association of contemporary magma bodies and geothermal potential in the Socorro area (e.g. Reiter and Smith, 1977; Chapin et al., 1978; Reilinger et a1., 1980). Compelling seismic data (Sanford et al., 1977; Brown et al., 1980) and releveling measurements (Reilinger et al., 1980) strongly support the existence of both shallow $(\sim 4-10 \mathrm{~km}$ deep) and deep $(\sim 20$ $\mathrm{km}$ ) bodies. Until the recent work of Reilinger et al. (1980) the bodies were referred to as the "Socorro magma body" but as sketched in Figure 9, there is now releveling evidence suggesting a separate magma body extending from Belen to Albuquerque. It is clear that the possible existence of a present day molten heat source beneath the Albuquerque area would modify our perception of the possible geothermal manifestations. Reilinger et al. (1980) have suggested additional leveling observations and detailed seismic studies to determine if such an active magma body is present between Albuquerque and Belen. As concluded by Harder et al. (1980), however, a deep ( $20 \mathrm{~km}$ ) magma chamber would not represent a geothermal resource, although it would indicate a potential for shallower magma heat sources. 
REGIONAL GEOPHYSICAL STUDIES

\section{Introduction}

Our study of the geothermal potential in the Albuquerque area concentrated on geophysical measurements which provide pertinent data for exploration, discovery, and assessment of the resource. Of obvious, primary importance is the collection of reliable temperature data at depth. Temperature data were obtained from oil test measurements, from bottom hole results recorded on geophysical logs run in municipal water wells, from our own measurements in available water wells, and in shallow gradient holes drilled as a part of our program. Estimates of base reservoir temperatures were obtained by geothermometry calculations based on water chemistry.

Modeling of existing gravity data provided regional estimates of potential reservoir locations and thicknesses. Regional seismicity, recently recorded in the Albuquerque area, revealed activity along faults which could act as conduits for thermal convection.

The application of resistivity methods in geothermal exploration is discussed and results are presented in a subsequent section on the Llano de Atrisco thermal anomaly. A surface magnetic survey is also included in the section on the assessment of the Llano de Atrisco area. 
Gravity

Gravity modeling was used primarily to determine the extent and thicknesses of the various aquifers present in the Albuquerque area (Table 1). Such aquifers would ultimately provide the reservoirs for geothermal waters and are thus a necessary requisite for a resource. A large thickness of highly porous and permeable sediments is an obvious asset since a large fluid storage volume would allow more total heat to be extracted and at greater depths higher temperatures are available. Our geothermal project fortuitously ran concurrent with another project supported by the U. S. Geological Survey aimed at geophysical evaluation of hydrological characteristics in the Albuquerque area. Gravity evaluations were completed and published by Birch (1980, 1982) as a part of this latter study. Birch compiled available gravity, geology, and deep well data and computer modeled fourteen gravity profiles through the Albuquerque basin (Figure 10). Profiles marked \#1 and \#2 are nearly coincident with geologic profiles $C$ and $B$ included in Figure 2. Figure 11 shows Birch's gravity model passing through the Carpender \#1 Atrisco (C\#1 A) well and Figure 12 represents results passing through the Shell \#l Santa Fe Pacific (S\#1 SFP) well.

Figures 11 and 12 both show profiles of the complete Bouguer anomaly (obtained from Figure 10) and the regional gravity field which was subtracted from it. The residual anomaly so obtained was modeled with blocks of various crustal densities using all available constraints (i.e. basement outcrops, geologic horizons reported from deep wells, and density results from geophysical logs). Densities used in the models 


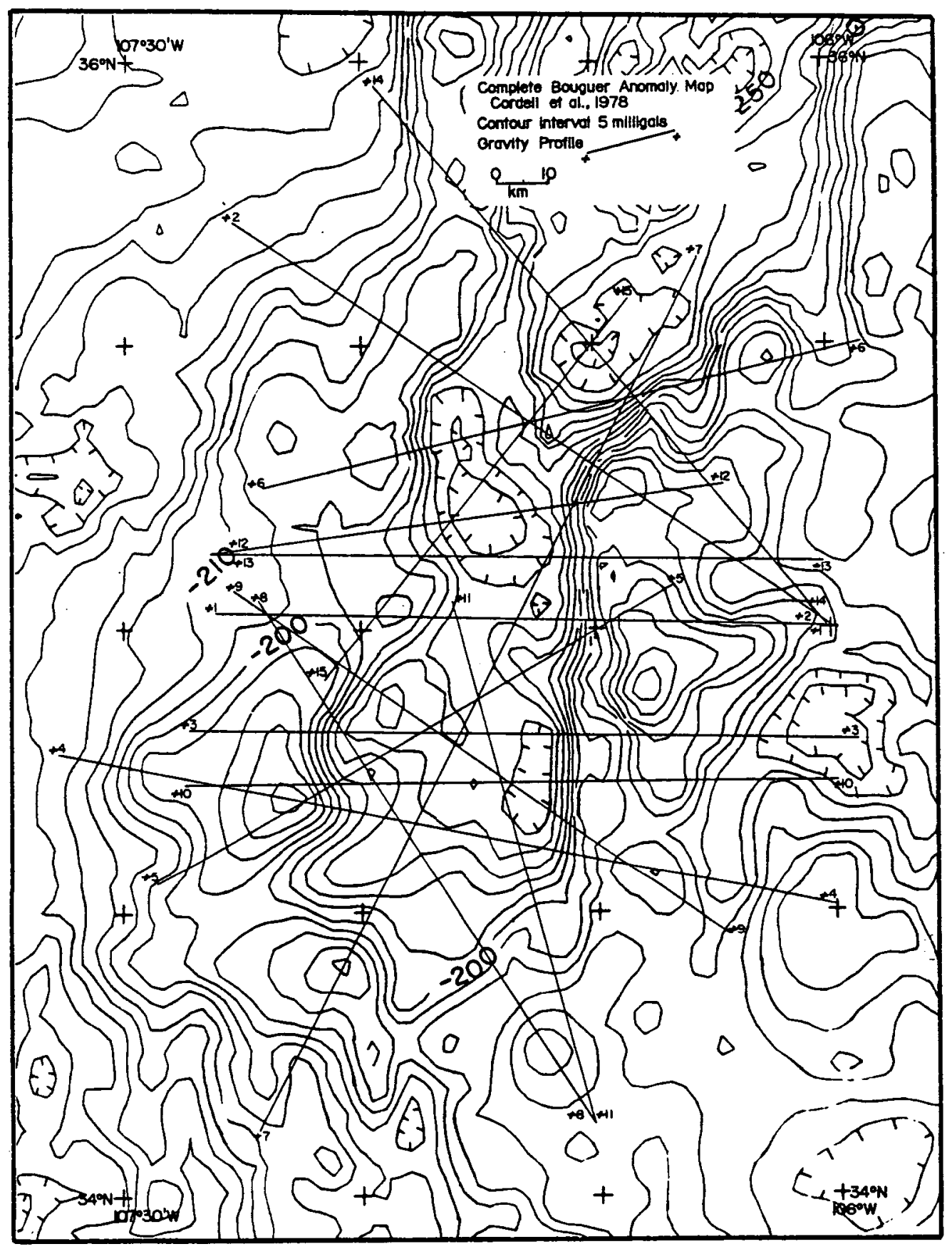

Figure 10. Complete Bouguer anomaly gravity map of Albuquerque basin (from Cordell et al., 1978) and locations of profiles modeled by Birch (1980, 1982). 
PROFILE $\# 2$

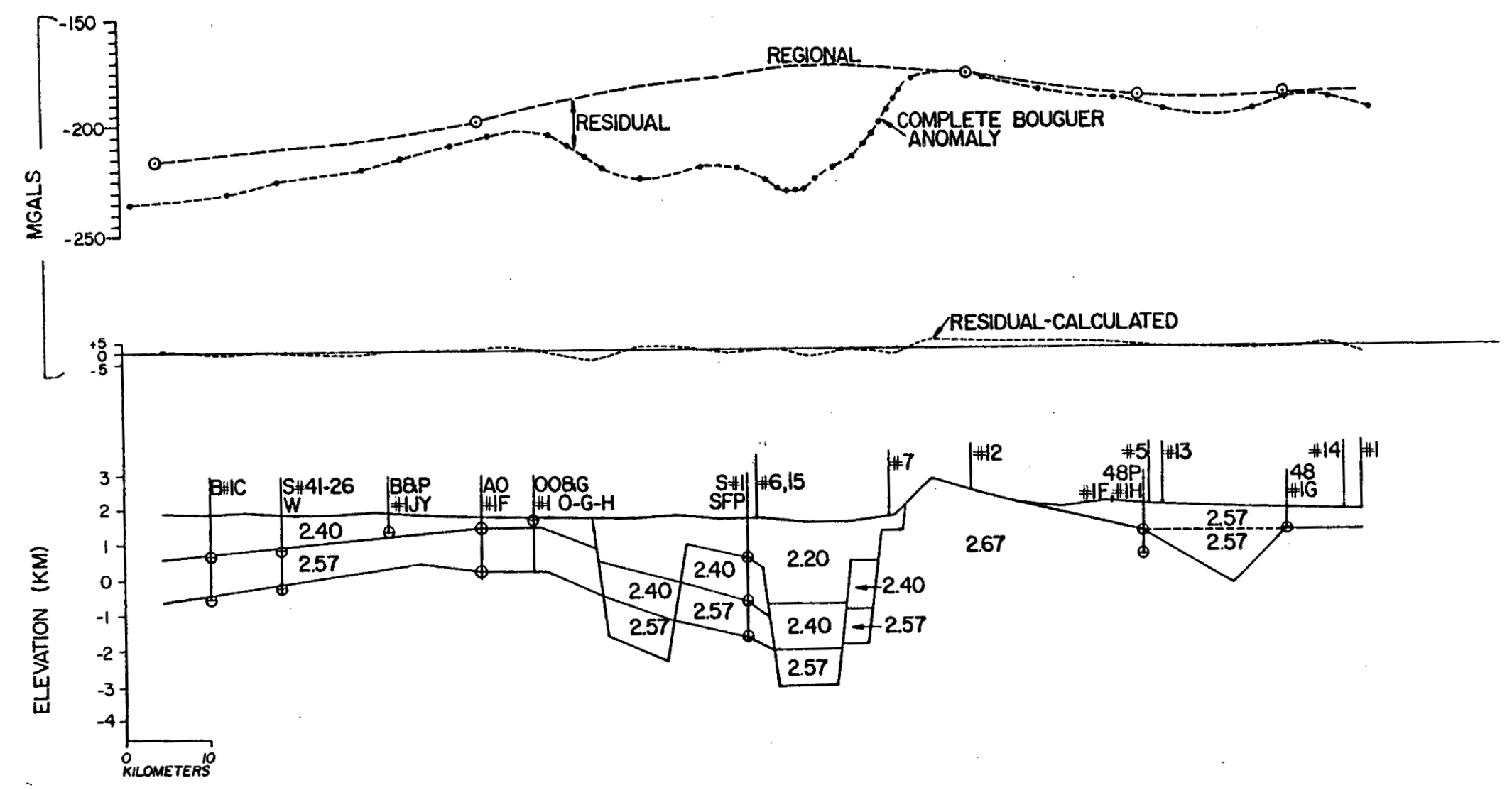

Figure 11. Modeled gravity profile 2 passing through Shell-Santa Fe Pacific No. 1 (S\#1 SFP) oil test well. Circles mark density layer interfaces $\left(\mathrm{g} / \mathrm{cm}^{3}\right.$ ) inferred from well data (from Birch, 1980; 1982). 


\section{PROFILE*I}
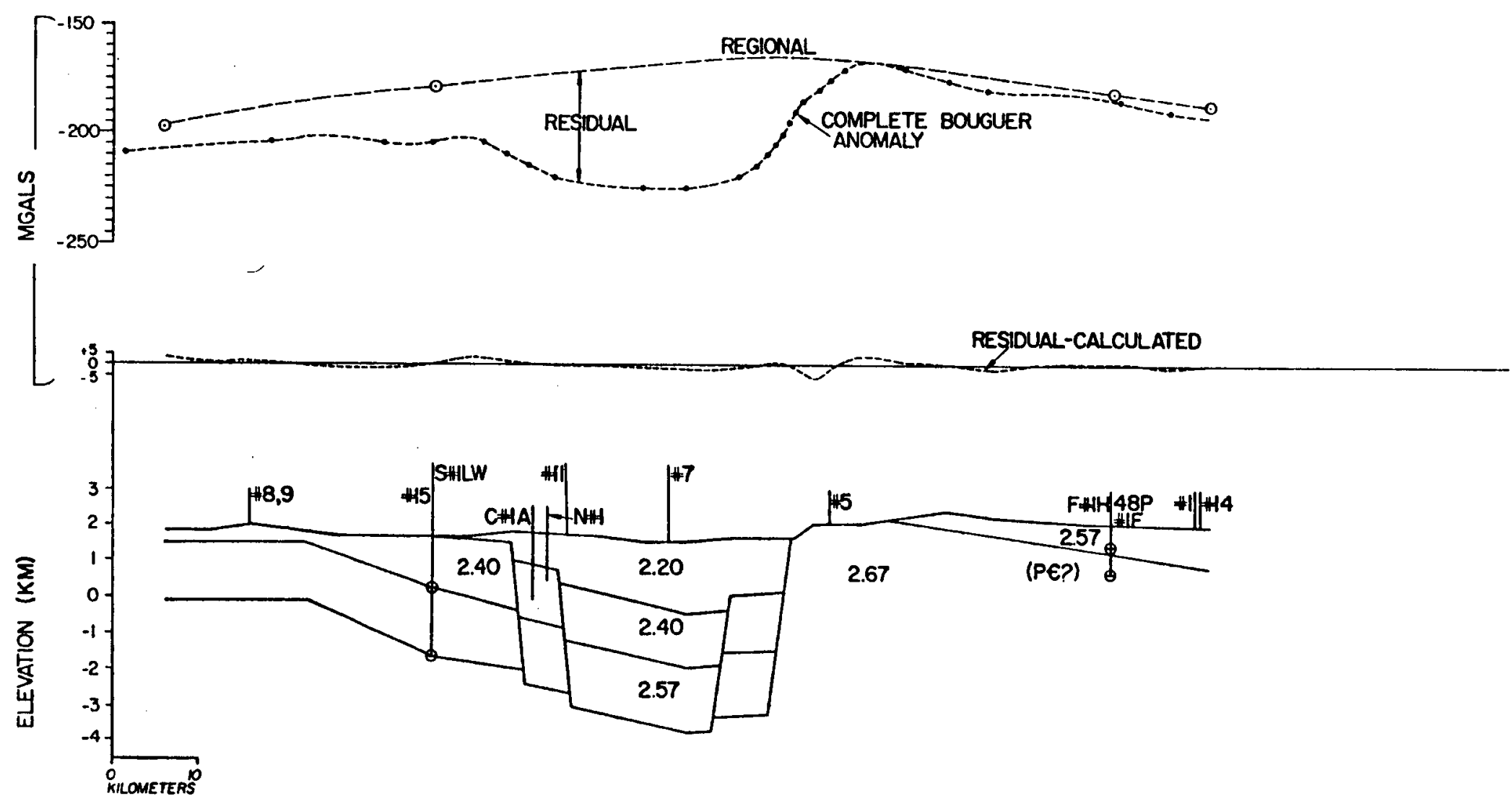

Figure 12. Modeled gravity profile 1 passing through Carpenter 3 No. 1 Atrisco (C\#1A) oil test well. Circles mark density layer interfaces $\left(\mathrm{g} / \mathrm{cm}^{3}\right)$ inferred fram well data (from Birch, 1980; 1982). 
and their correspondence to the aquifer age series listed in Table 1 are: Recent to Miocene (Neogene), $2.20 \mathrm{~g} / \mathrm{cm}^{3} ; 01$ igocene, Eocene, Cretaceous, and Jurassic, $2.40 \mathrm{~g} / \mathrm{cm}^{3}$; Triassic and Paleozoic, $2.57 \mathrm{~g} / \mathrm{cm}^{3}$, and Precambrian, $2.67 \mathrm{~g} / \mathrm{cm}^{3}$. Of these units the Santa Fe Formation $\left(2.20 \mathrm{~g} / \mathrm{cm}^{3}\right)$ is by far the most important aquifer available for potential geothermal fluid storage. Deeper strata including the Precambrian basement yield little or no water under typical conditions. They, therefore, would not be considered as potential geothermal reservoirs except under unusually favorable circumstances.

Gravity modeling in Figures 11 and 12 clearly shows that several kilometers of low density $\left(2.20 \mathrm{~g} / \mathrm{cm}^{3}\right)$, permeable Santa Fe sediments are present in the Albuquerque area. Noteworthy in these profiles are the deep normal faults, in general agreement with Kelley's projections (Figure 2). Precise location and depth of unexposed, deep faults cannot be inferred from gravity alone; however, the geologic (Figure 2) and gravity modeling (Figures 11 and 12) certainly suggests the likelihood that faults are available for deep thermal convection.

Modeling results from all fourteen gravity profiles have been combined to produce Figure 13, a map of the thickness of the $2.20 \mathrm{~g} / \mathrm{cm}^{3}$ deposits in the Albuquerque basin. Over most of the basin the unit is about $1.5 \mathrm{~km}$ thick. As expected, the layer is thin along the basin margins; it is also less than $0.5 \mathrm{~km}$ thick at the southern terminus of the basin. The greatest thickness of Santa Fe sediments (over $2.5 \mathrm{~km}$ ) is estimated to occur west of the Manzano Mountains and in the northeastern section of the basin. Most of the city of Albuquerque is underlain by an average of $1.5 \mathrm{~km}$ of Santa Fe sediments with some thicknesses exceeding $2.0 \mathrm{~km}$. Birch (1982) has calculated the total 


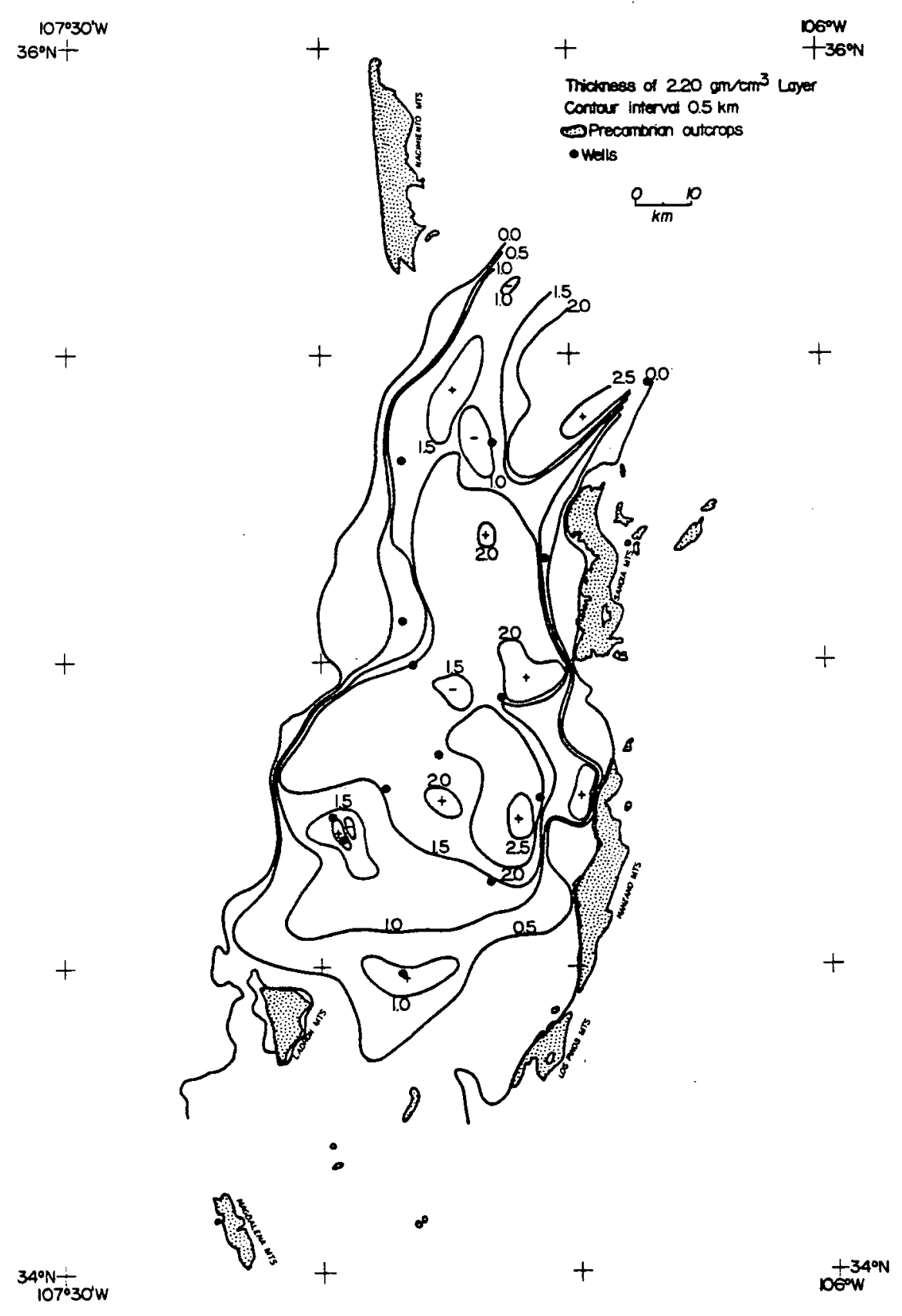

Figure 13. Thickness of $2.20 \mathrm{~g} / \mathrm{cm}^{3}$ low density fill in Albuquerque basin calculated by gravity modeling (from Birch 1980, 1982). 
volume of Santa Fe deposits to be about $7000 \mathrm{~km}^{3}$ which upon using $27 \%$ water saturated porosity yields about $1900 \mathrm{~km}^{3}$ total water volume. This is obviously a vast reservoir of fluid; the fraction of this heat transfer medium that has geothermal significance is, of course, unknown.

\section{Seismicity}

Earthquake activity may be an important factor in locating prospective geothermal sites as active faulting, which may control fluid flow and igneous intrusion, would be associated with seismicity. Contemporary seismic activity provides evidence that fault zones are active and, therefore, are likely to be open (not sealed or cemented). They may, consequently, act as conduits for deep ground-water circulation or convection. Magma intrusion has long been known to be associated with swarm earthquake activity. Approximately 75 percent of the recent microearthquake activity in the Socorro area, about $100 \mathrm{~km}$ south of Albuquerque, has occurred in swarms (Sanford et al., 1979). Thus, Sanford et a1. (1979) suggest that earthquake activity and unusually high heat flow in the Socorro area can be explained by intrusion of magma into the mid- to upper crust.

Earthquake activity in the Albuquerque area from the beginning of instrumental studies in New Mexico in 1962 until 1977 has been much less than the Socorro area. Seismicity increased dramatically in 1978-79 when about 300 small earthquakes of local magnitudes up to 2.5 were observed near the Albuquerque volcanoes (Jaksha et al., 1981). The earthquake sequence between September, 1978 and Apri1, 1979 was generated in a small epicentral region about $2.5 \mathrm{~km}$ west of the 
southernmost volcanic cone (Figure 14). The activity was studied using the permanent 13-element U. S. Geological Survey seismic array in the Albuquerque basin and a small network of portable stations.

Jaksha et al. (1981) selected 93 of the earthquakes which passed certain "goodness" criteria to estimate epicenter and hypocenter locations. These epicentral locations are plotted in Figure 15 which aiso shows the variation in hypocenter depths as a function of longitude. The source region for the earthquakes is obviously quite small; inherent location errors (estimated to be about $1 \mathrm{~km}$ in epicentral location) result in no significance to the distinct east-west trend of epicenters just above $35.124^{\circ} \mathrm{N}$ in Figure 15. The average hypocenter for the events is latitude $35.124^{\circ} \mathrm{N}$, longitude $106.800^{\circ} \mathrm{W}$ at a depth of $9.5 \mathrm{~km}$. A composite fault plane solution for the earthquakes (Jaksha et al., 1981) suggests a close correlation with the County Dump fault and the fissure of the Albuquerque volcanoes (Figure 14). Although the 1978-79 microearthquake sequence occurred in swarms, Jaksha et a1. (1981) consider the actual cause of the activity to be uncertain. It is thought to be associated with a small buried fault auxiliary to the surface features.

An interesting aspect of the present seismicity in the Albuquerque area and in the most seismically active segment of the Rio Grande rift near Socorro is that major young rift bounding faults are seismically inactive. An example of these faults would be those bordering the rift along the Sandia Mountains (Figure 2). Sanford et al. (1979) suggest that such observations indicate that seismic activity may not be the result of simple east-west extension of the rift but may be associated with magma injection at the present time. The shallow distribution of 


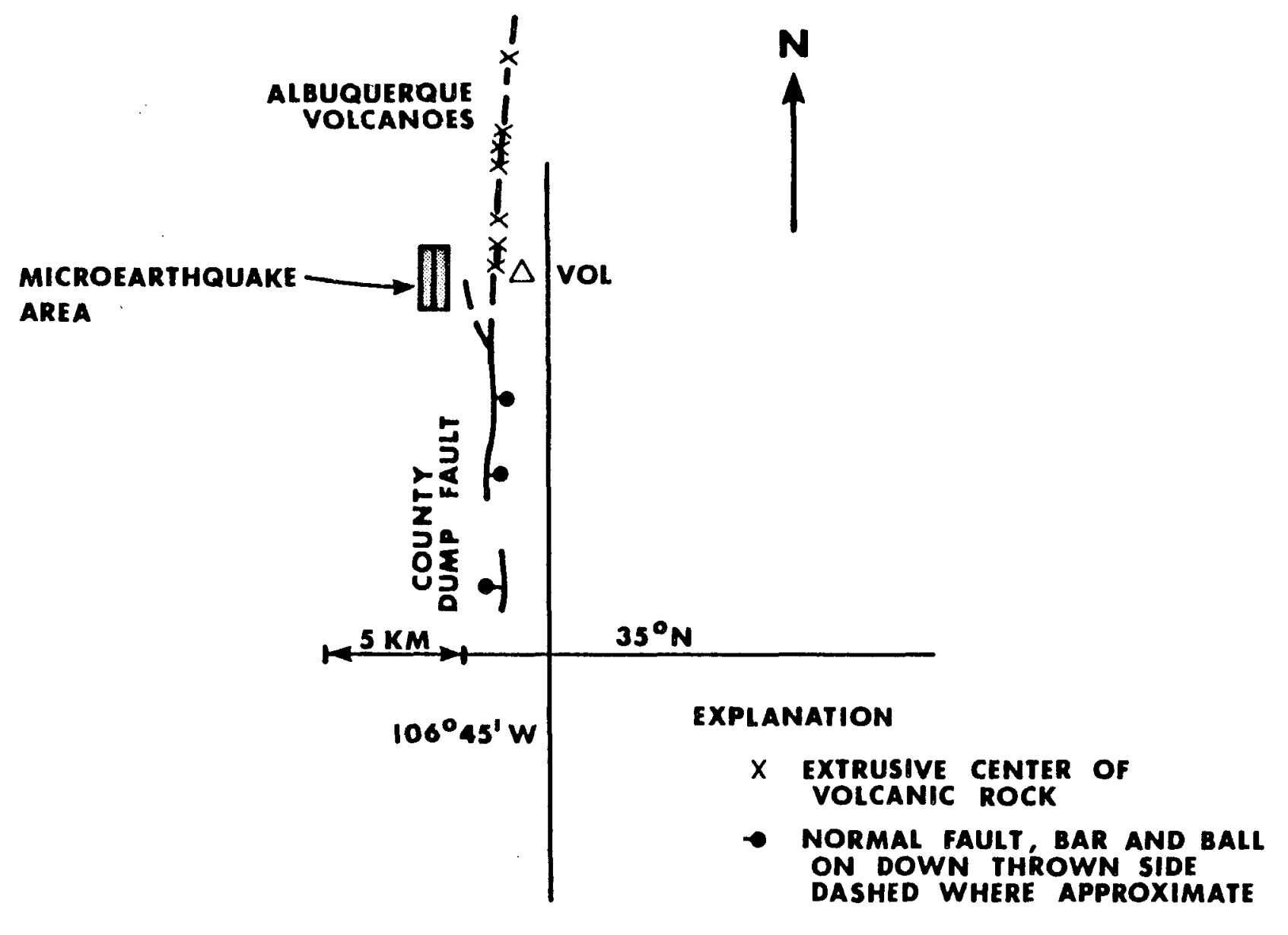

$\triangle$ PERMANENT SEISMIC

Figure 14. Map of microearthquake area near Albuquerque volcanoes (from Jaksha et a].., 1981 ). 


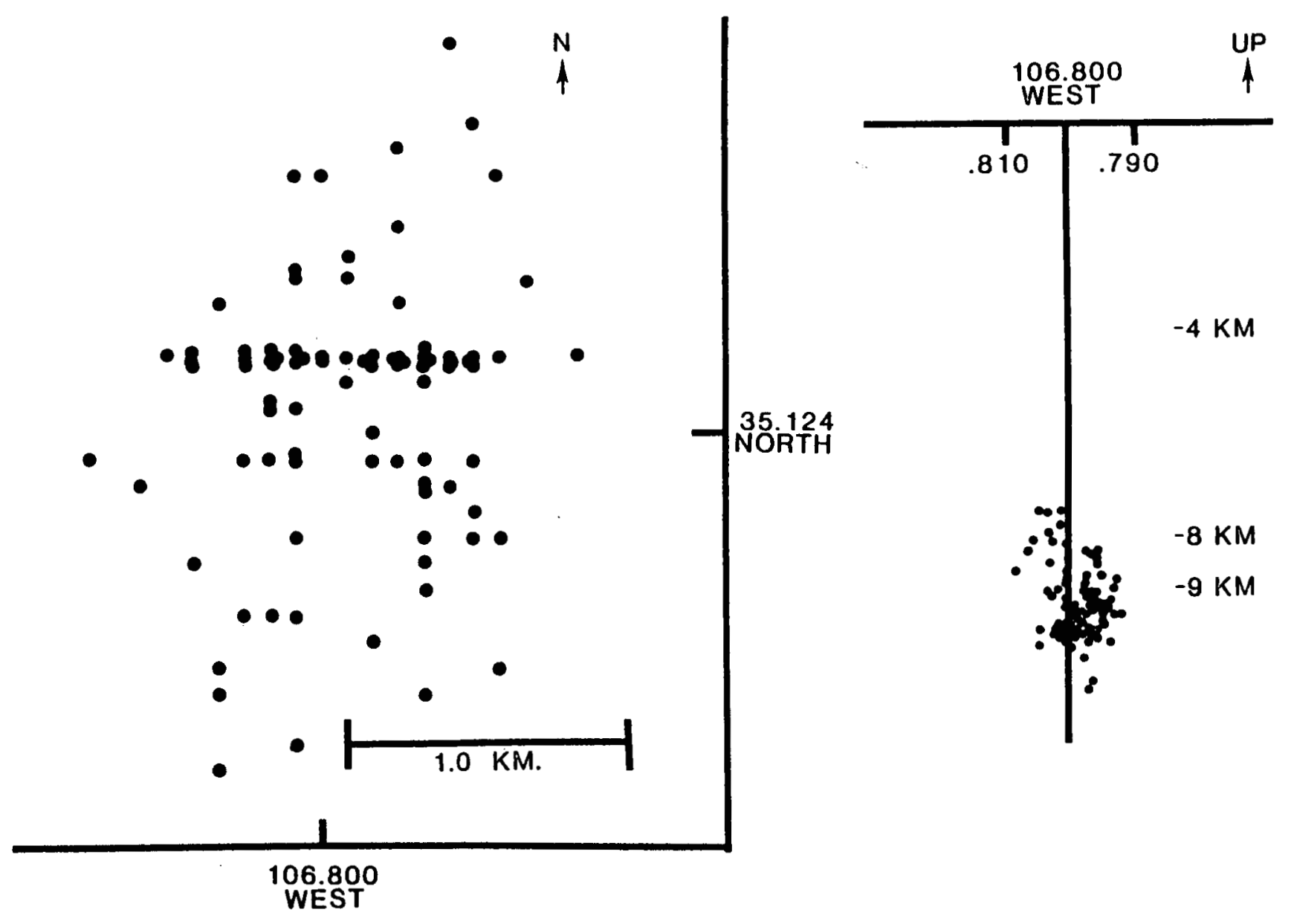

Figure 15. Map of epicenters of microearthquakes (left) and section with earthquake focal depths (right) near Albuquerque volcanoes (from Jaksha et al., 1981). 
well determined hypocentral depths, all less than $13.5 \mathrm{~km}$ in the Socorro area, suggests abnormally high temperatures at depth (Sanford et al., 1979). Deeper deformation would take place by ductile flow rather than by brittle fracturing. The shallow focal depths computed for the 1978-79 Albuquerque earthquakes $(<11 \mathrm{~km})$ are in agreement with this hypothesis. 
Thermal

Ultimate emphasis in any geothermal evaluation program must be placed on thermal data including heat flow, bottom hole temperatures, and temperature logging.

Heat Flow

A major heat flow anomaly with heat flow greater than $105 \mathrm{~mW} / \mathrm{m}^{2}(2.5$ HFU) has been delineated along the western portion of the Rio Grande rift (Reiter et al., 1975; 1978; 1979). This trend of enhanced heat flow on the western margin of the rift is consistent with the heat flow values in the vicinity of Albuquerque. These data are tabulated in Table 2 where fourteen values are listed (Reiter et al., 1975). The data locations are shown (Figure 26) in the subsequent section on Geothermometry. The mean of these heat flow data is $84 \pm 25 \mathrm{~mW} / \mathrm{m}^{2}(2.0$ $\pm 0.6 \mathrm{HFU})$. The six western heat flow values average $105 \pm 17 \mathrm{~mW} / \mathrm{m}^{2}$ $(2.5 \pm 0.4 \mathrm{HFU})$, whereas, the eight eastern values average only $63 \pm 13$ $\mathrm{mW} / \mathrm{m}^{2}(1.5 \pm 0.3 \mathrm{HFU})$. The highest value of heat flow $\left(129 \mathrm{~mW} / \mathrm{m}^{2} ; 3.1\right.$ $\mathrm{HFU}$ ) is in the Rio Puerco valley, $35 \mathrm{~km}$ west of Albuquerque; the lowest value of $45 \mathrm{~mW} / \mathrm{m}^{2}(1.1 \mathrm{HFU})$ occurs just outside the Albuquerque city limits to the southwest. Bottom Hole Temperatures

Bottom hole temperatures from oil test wells were collected from the well log files of the State of New Mexico $0 i 1$ Conservation Division as one of the first steps in our exploration program. These initial data, and three newer results, are listed in Table 3 and plotted in Figure 16. The three most recent data were obtained through personal communications 


\section{TABLE 2}

SUMMARY OF HEAT FLOW DATA

NEAR ALBUQUERQUE, NEW MEXICO

(From Reiter et al., 1975)

Locality

Location

Locality
Albuquerque
Albuquerque/SE \#1
Albuquerque/SE \#2
Bibo/North
Holweg
Marquez
Marquez/SE
Ortiz Mtn.
Rio Puerco \#1
Rio Puerco \#2
Rio Puerco \#3
San Felipe/East
San Pedro \#1
San Pedro \#2

Lat. Long.

Heat Flow

$\left(\mathrm{mW} / \mathrm{m}^{2}\right)$

(HFU)

$\begin{array}{llrl}35^{\circ} 03^{\prime} & 106^{\circ} 31^{\prime} & 45 & 1.08 \\ 34^{\circ} 56^{\prime} & 106^{\circ} 33^{\prime} & 65 & 1.56 \\ 33^{\circ} 56^{\prime} & 106^{\circ} 33^{\prime} & 60 & 1.43 \\ 35^{\circ} 13^{\prime} & 107^{\circ} 19^{\prime} & 108 & 2.58 \\ 35^{\circ} 09^{\prime} & 106^{\circ} 16^{\prime} & 66 & 1.58 \\ 35^{\circ} 17^{\prime} & 107^{\circ} 15^{\prime} & 90 & 2.14 \\ 35^{\circ} 15^{\prime} & 107^{\circ} 13^{\prime} & 88 & 2.11 \\ 35^{\circ} 20^{\prime} & 106^{\circ} 11^{\prime} & 74 & 1.76 \\ 35^{\circ} 13^{\circ} & 107^{\circ} 01^{\prime} & 129 & 3.08 \\ 35^{\circ} 12^{\prime} & 107^{\circ} 01^{\prime} & 95 & 2.27 \\ 35^{\circ} 12^{\prime} & 107^{\circ} 05^{\prime} & 111 & 2.66 \\ 35^{\circ} 18^{\prime} & 106^{\circ} 15^{\prime} & 78 & 1.86 \\ 35^{\circ} 15^{\prime} & 106^{\circ} 11^{\prime} & 56 & 1.34 \\ 35^{\circ} 15^{\circ} & 106^{\circ} 11^{\prime} & 54 & 1.29\end{array}$




\section{TABLE 3}

OIL AND GAS WELL BOTTOM HOLE TEMPERATURES AND

THERMAL GRADIENTS NEAR ALBUQUERQUE, NEW MEXICO

(Temperatures recorded on borehole logs; gradients computed using $15^{\circ} \mathrm{C}$ mean annual surface temperature.)

Well Name Location Spudding Depth Temperature Gradient

\begin{tabular}{|c|c|c|c|c|c|c|c|}
\hline & $\left(T_{\bullet} / R_{0} / \mathrm{Sec}.\right)$ & Date & $(f t)$ & $(m)$ & $\left({ }^{O} F\right)$ & $\left({ }^{\circ} \mathrm{C}\right)$ & $\left({ }^{\mathrm{O}} \mathrm{C} / \mathrm{km}\right)$ \\
\hline Long Dalies No. 1 & $7 N / 1 E / 31$ & $4 / 11 / 52$ & 6091 & 1856 & 153 & 67 & 28 \\
\hline \multicolumn{8}{|l|}{ Shell-Santa $\mathrm{Fe}$} \\
\hline \multirow[t]{2}{*}{ Pacific No. 1} & $13 N / 3 E / 18$ & $6 / 19 / 72$ & 7683 & 2342 & 179 & 82 & 29 \\
\hline & & & 9375 & 2857 & 212 & 100 & 30 \\
\hline \multicolumn{8}{|l|}{ Shell-Laguna- } \\
\hline \multirow[t]{2}{*}{ Wilson No. 1} & $9 N / 1 W / 8$ & $9 / 21 / 72$ & 3982 & 1214 & 136 & 58 & 35 \\
\hline & & & 10975 & 3345 & 245 & 118 & 31 \\
\hline \multicolumn{8}{|l|}{ Shell-Santa Fe } \\
\hline Pacific No. 2 & $6 N / 1 W / 29$ & $3 / 29 / 74$ & 14020 & 4273 & 322 & 161 & 34 \\
\hline Shell-Isleta No. 1 & $7 N / 2 E / 7$ & $10 / 25 / 74$ & 16346 & 4982 & 374 & 190 & 35 \\
\hline \multicolumn{8}{|l|}{ Transocean } \\
\hline Isleta No. 1 & $8 N / 3 E / 8$ & $10 / 4 / 78$ & 10370 & 3161 & 235 & 113 & 31 \\
\hline Shell-Isleta No. 2 & $8 N / 2 E / 16$ & $11 / 23 / 79$ & 21266 & 6482 & 450 & 232 & 33 \\
\hline \multicolumn{8}{|l|}{ Shell West Mesa } \\
\hline Federal No. 1-24A & $11 N / 1 E / 24$ & $12 / 30 / 80$ & 19366 & 5902 & 380 & 193 & 30 \\
\hline
\end{tabular}




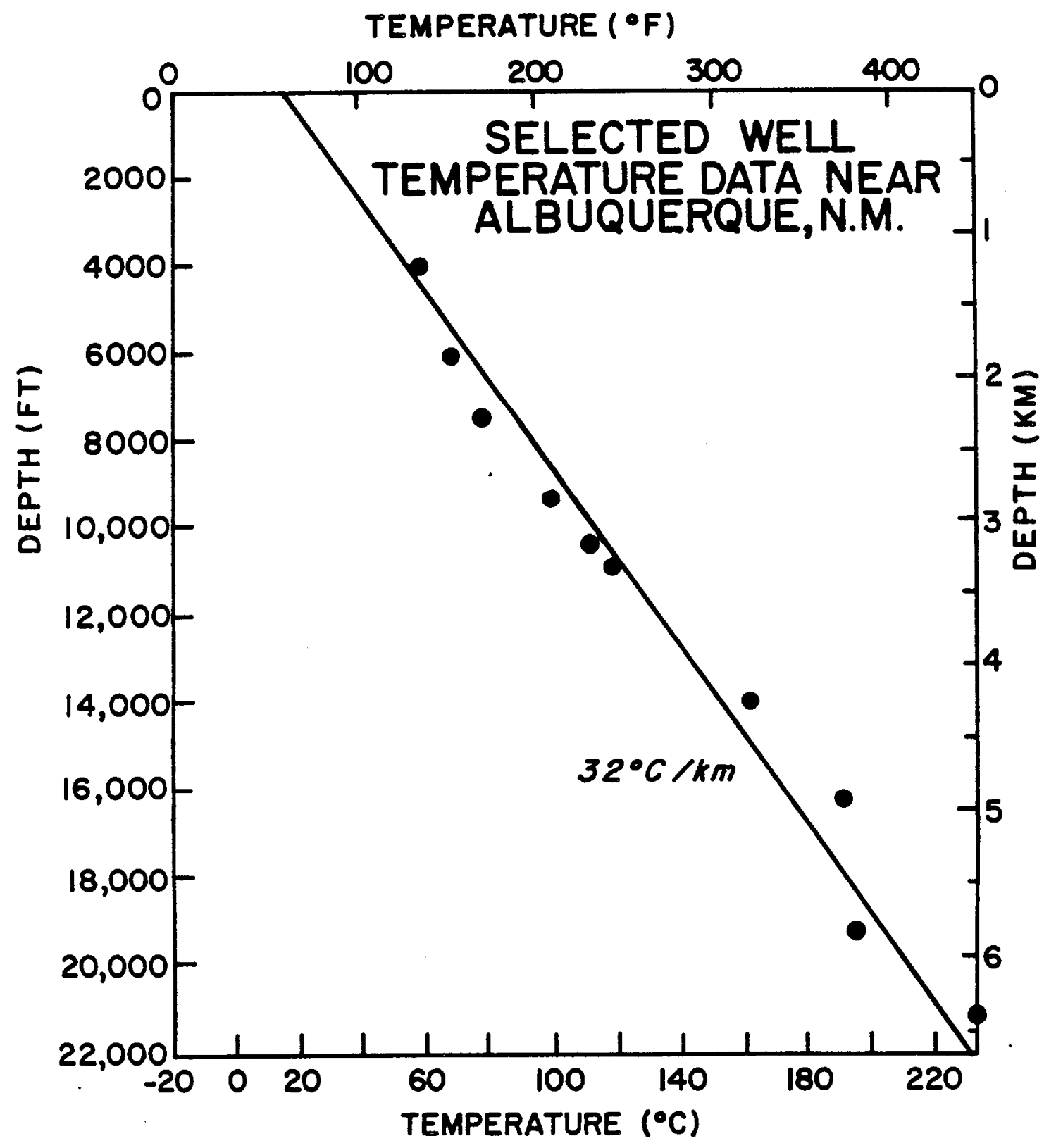

Figure 16. $0 i 1$ and gas well bottom hole temperature data near Albuquerque. 
with K. Hatton of the State of New Mexico Energy and Minerals Department in Santa Fe. The locations of the wells are given on the map in Figure 17. The results from the eight wells tabulated in Table 3 and plotted in Figure 16 are characterized by temperature gradients calculated using a mean annual surface temperature of $15^{\circ} \mathrm{C}$ for all wells. This is near the average value calculated from records of the U. S. Weather Service at the Albuquerque airport from July 1978 to June $1980\left(14.1^{\circ} \mathrm{C}\right)$. The gradients listed in Table 3 vary from 28 to $35^{\circ} \mathrm{C} / \mathrm{km}$ and average $32^{\circ} \mathrm{C} / \mathrm{km}$. Thus, we have considered temperature gradients to be about normal if they are approximately $30^{\circ} \mathrm{C} / \mathrm{km}$ in the Albuquerque area.

Approximately one hundred municipal water wells have been drilled in the Albuquerque area in twenty-seven well fields. Many of the wells were commercially logged with conventional downhole geophysical tools, typically induction-electric, microlog, and formation density logs. The logging tools often included a maximum reading thermometer. The maximum readings were assumed to represent the bottom hole temperature and were recorded as such on the well log records. A search of the archives containing the logs at Gordon Herkenhoff and Associates, Inc. yielded bottom hole temperatures from nearly every municipal well field. These values were converted to temperature gradients by assuming a linear gradient and using a mean annual temperature estimate of $15^{\circ} \mathrm{C}$ at the surface. Bottom hole temperature data and temperature gradients thus determined are listed in Table 4. Figure 18 is a plot of the bottom hole temperatures versus depth with an arbitrary reference temperature gradient of $40^{\circ} \mathrm{C} / \mathrm{km}$ indicated. Well depths range from 300 to over $600 \mathrm{~m}$; 


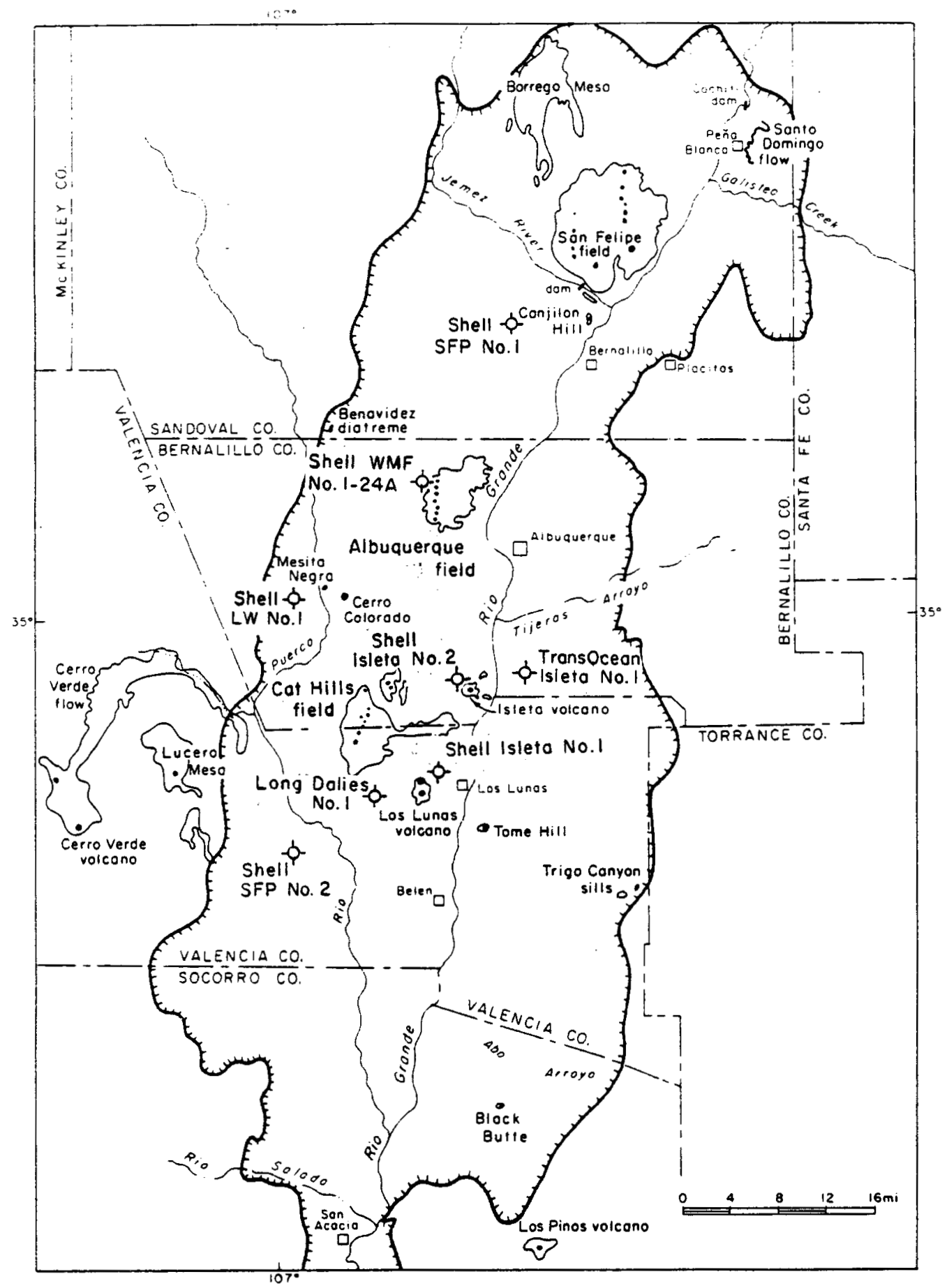

Figure 17. Location map showing oil and gas wells yielding bottom hole temperature data near Albuquerque (base map from Kelley and Kudo, 1978). 


\section{TABLE 4}

WATER WELL BOTTOM HOLE TEMPERATURES AND

THERMAL GRADIENTS IN ALBUQUERQUE, NEW MEXICO

(Temperatures recorded on borehole logs; gradients computed using $15^{\circ} \mathrm{C}$ mean annual surface temperature.)

\begin{tabular}{|c|c|c|c|c|c|}
\hline \multirow[t]{2}{*}{ Well Name } & \multicolumn{2}{|c|}{ Depth } & \multicolumn{2}{|c|}{ Temperature } & \multirow{2}{*}{$\begin{array}{l}\text { Gradient } \\
\left({ }^{\circ} \mathrm{C} / \mathrm{km}\right)\end{array}$} \\
\hline & $(\mathrm{ft})$ & $(m)$ & $\left({ }^{0} \mathrm{~F}\right)$ & $\left({ }^{\circ} \mathrm{C}\right)$ & \\
\hline Almeda \#1 & 1382 & 421 & 88 & 31 & 38 \\
\hline Atrisco $\# 5$ & 1420 & 433 & 88 & 31 & 37 \\
\hline Charles \#1 & 1065 & 325 & 81 & 27 & 37 \\
\hline Charles \#2 & 1033 & 315 & 81 & 27 & 38 \\
\hline Charles \#4 & 1053 & 321 & 90 & 32 & 53 \\
\hline College \#2 Zone 2 & 1630 & 498 & 88 & 31 & 32 \\
\hline College \#3 Zone $1 \mathrm{~W}$ & 1488 & 454 & 82 & 28 & 29 \\
\hline Don \#1 & 1607 & 490 & 81 & 27 & 24 \\
\hline Duranes \#1 & 1021 & 311 & 76 & 24 & 29 \\
\hline Levitt \#1 & 1221 & 372 & 74 & 23 & 22 \\
\hline Levitt \#2 & 1241 & 378 & 72 & 22 & 19 \\
\hline Leyendecker \#2 & 1014 & 309 & 75 & 24 & 29 \\
\hline Leyendecker \#3 & 1026 & 313 & 70 & 21 & 19 \\
\hline Leyendecker \#4 & 1017 & 310 & 70 & 21 & 19 \\
\hline Lomas \#1 & 1343 & 409 & 72 & 22 & 17 \\
\hline Lomas \#2 & 1582 & 482 & 80 & 26 & 23 \\
\hline Lomas \#3 & 1616 & 493 & 80 & 26 & 22 \\
\hline Lomas \#7 & 1708 & 521 & 88 & 31 & 31 \\
\hline Lomas \#8 & 1704 & 519 & 82 & 27 & 23 \\
\hline Love \#3 & 1274 & 388 & 83 & 28 & 34 \\
\hline Love \#4 & 1282 & 391 & 95 & 35 & 51 \\
\hline Love \#5 & 1252 & 382 & 80 & 26 & 29 \\
\hline Paradise Hilles \#1 & 1201 & 366 & 74 & 23 & 22 \\
\hline Ponderosa \#4 & 1753 & 534 & 78 & 25 & 19 \\
\hline Ponderosa \#9 & 1808 & 551 & 95 & 35 & 36 \\
\hline Ridgecrest \#2 & 1552 & 473 & 76 & 24 & 19 \\
\hline Ridgecrest \#4 & 1448 & 441 & 69 & 20 & 11 \\
\hline Rio Rancho \#8 & 2006 & 611 & 88 & 31 & 26 \\
\hline
\end{tabular}




$$
\frac{\text { TABLE } 4}{\text { continued }}
$$

\begin{tabular}{|c|c|c|c|c|c|}
\hline \multirow[t]{2}{*}{ Well Name } & \multicolumn{2}{|c|}{ Depth } & \multicolumn{2}{|c|}{ Temperature } & \multirow{2}{*}{$\begin{array}{l}\text { Gradie } \\
\left({ }^{\circ} \mathrm{C} / \mathrm{km}\right)\end{array}$} \\
\hline & $(f t)$ & $(m)$ & $\left({ }^{O} \mathrm{~F}\right)$ & $\left({ }^{0} \mathrm{C}\right)$ & \\
\hline San Jose \#7 & 1014 & 309 & 75 & 24 & 29 \\
\hline San Jose \#10 & 1200 & 366 & 77 & 25 & 27 \\
\hline Santa Barbara \#1 & 1011 & 308 & 71 & 21 & 19 \\
\hline Thomas \#1 & 1097 & 334 & 81 & 27 & 36 \\
\hline Thomas \#2 & 1225 & 373 & 82 & 27 & 32 \\
\hline Thomas \#3 & 1192 & 363 & 80 & 26 & 30 \\
\hline Thomas \#4 & 1014 & 309 & 80 & 26 & 36 \\
\hline Vol-Andia \#2 & 1030 & 314 & 73 & 23 & 25 \\
\hline Vol-Andia \#3 & 1027 & 313 & 100 & 38 & 73 \\
\hline Vol-Andia \#4 & 1022 & 311 & 85 & 29 & 45 \\
\hline Vol-Andia \#5 & 1031 & 314 & 100 & 38 & 73 \\
\hline Volcano Cliffs \#1 & 1204 & 367 & 92 & 33 & 49 \\
\hline Volcano $\mathrm{Cliffs} \# 3$ & 1648 & 502 & 116 & 46 & 62 \\
\hline West Mesa \#1 & 1181 & 360 & 80 & 26 & 31 \\
\hline West Mesa \#2 & 1445 & 440 & 115 & 46 & 70 \\
\hline West Mesa \#3 & 1424 & 434 & 75 & 24 & 21 \\
\hline Yale \#1 & 1008 & 307 & 78 & 26 & 36 \\
\hline Walker \#1 & 1786 & 544 & 100 & 38 & 42 \\
\hline Walker \#2 & 1739 & 530 & 90 & 32 & 32 \\
\hline
\end{tabular}




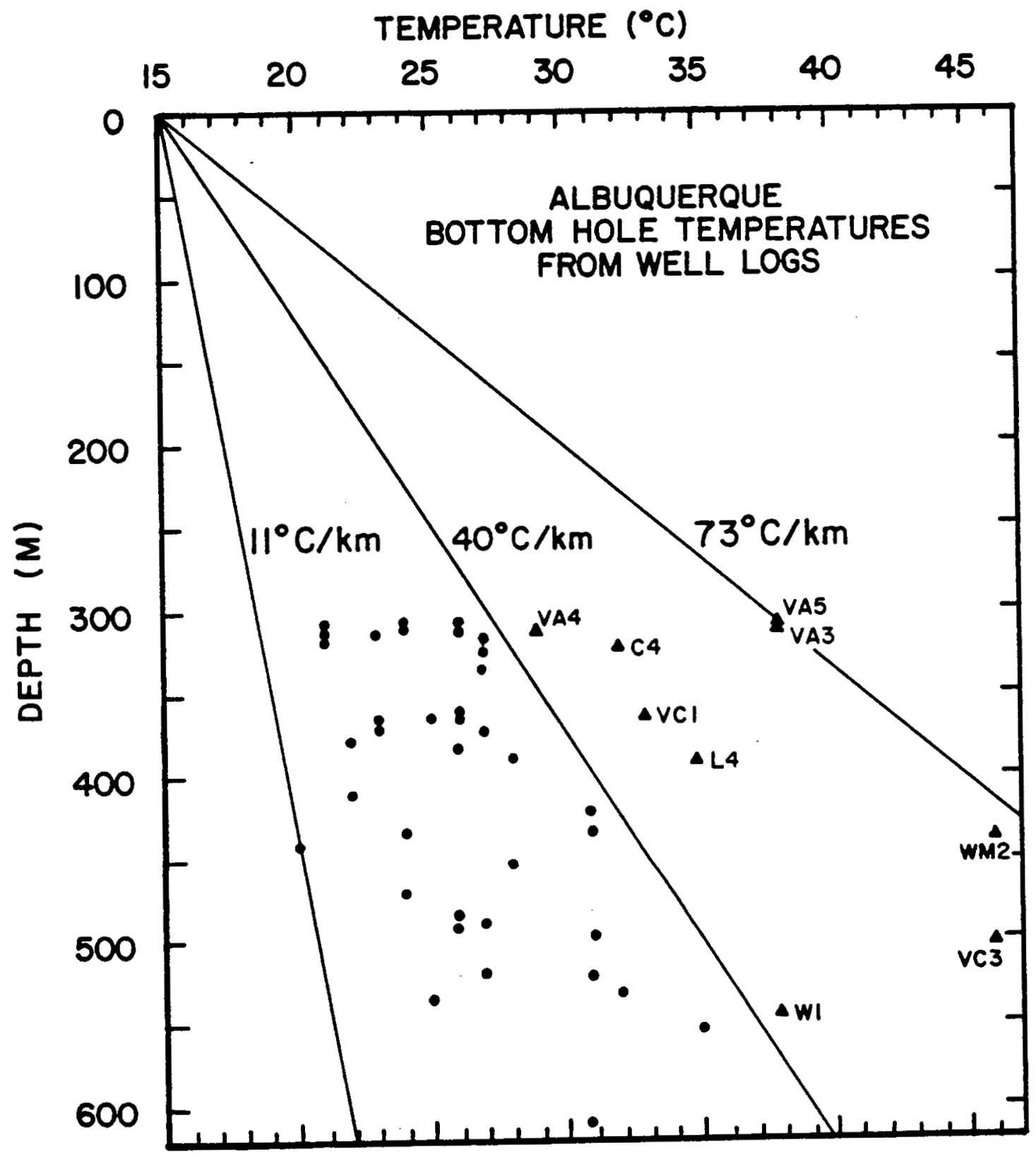

Figure 18. Water well bottom hole temperature data in Albuquerque: C4, L4, VA3, VA4, VA5, VC1, VC3, WM2, and W1 are Charles \#4, Love \#4, Vol-Andia \#3, \#4, \#5, Volcano Cliffs \#1, \#3, West Mesa \#2, and Walker \#1 wells, respectively. 


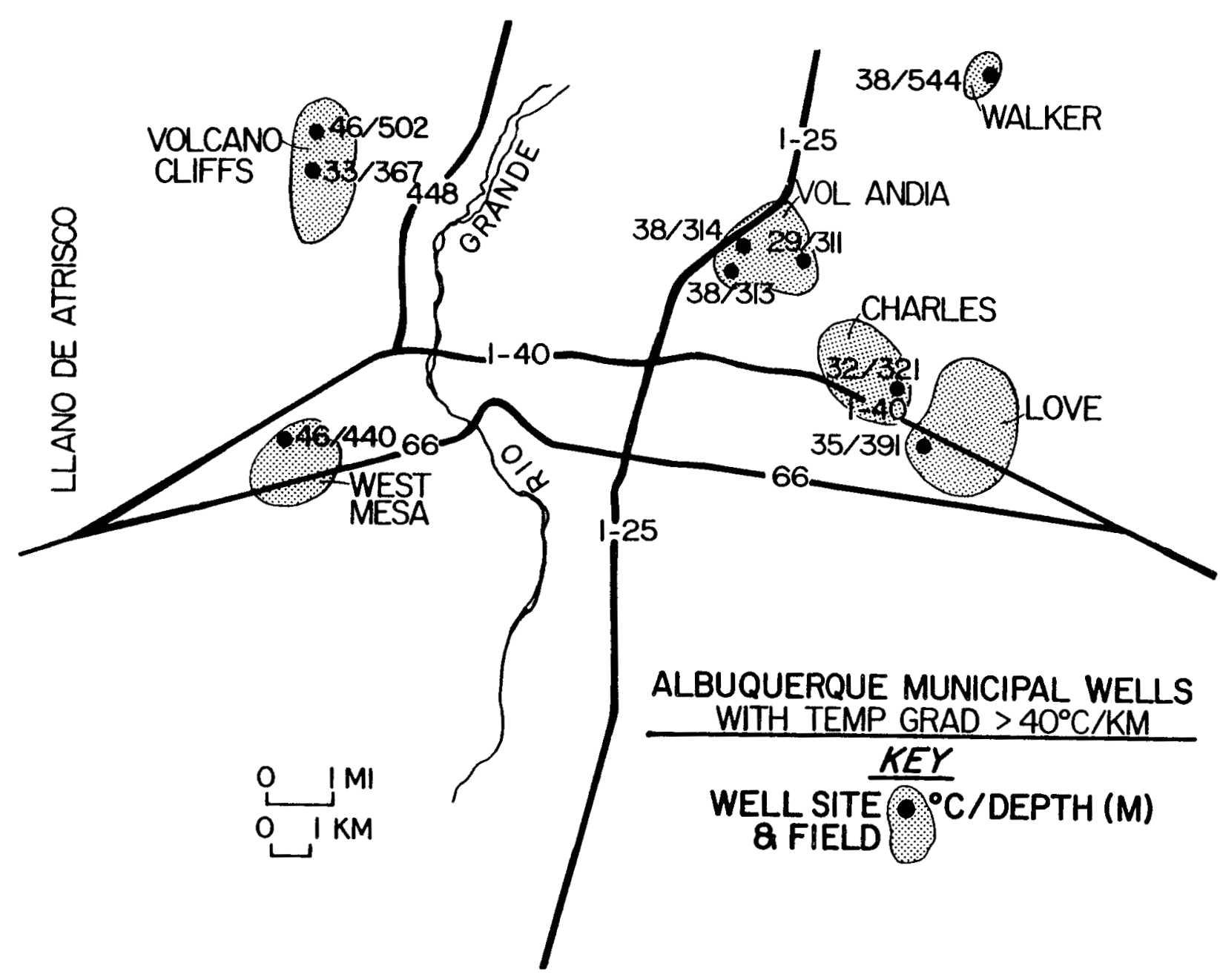

Figure 19. Location map showing Albuquerque municipal water well fields indicating thermal gradients over $40^{\circ} \mathrm{C} / \mathrm{km}$. 
calculated temperature gradients vary considerably from $11^{\circ} \mathrm{C} / \mathrm{km}$ to over $70^{\circ} \mathrm{C} / \mathrm{km}$. Mapped in Figure 19 are the six well fields where temperature gradients exceeding $40^{\circ} \mathrm{C} / \mathrm{km}$ were calculated by the above procedure. Two basic trends, evident in Figure 19, are a thermal anomaly on the west side of Albuquerque (Volcano Cliffs - West Mesa fields) and one to the east (Vol Andia to Love fields). Data as presented in Figures 18 and 19 are very valuable free geothermal targeting information; however, there are several pitfalls evident in dealing with commercial well logs. Wells are usually logged before thermal equilibrium is reached and recording discrepancies are often noted on the 1 og headings themselves. A more serious, and thus far enigmatic, aspect of using bottom hole well temperatures obtained from geophysical logs is the marked contrast between temperatures at similar depths within a given well field. For example, West Mesa well \#2 lists $46^{\circ} \mathrm{C}$ at $440 \mathrm{~m}$ depth compared to $24^{\circ} \mathrm{C}$ recorded at West Mesa \#3 at $434 \mathrm{~m}$ only $1.6 \mathrm{~km}$ away. We have measured temperature differences at similar depths in nearby wells in our own temperature logging program (to be described in the following section) but not of the magnitude seen in the bottom hole temperature data. We have noticed that many of the discrepancies such as observed in the West Mesa field can be correlated with the time of the year when the wells were logged. For example, the West Mesa \#2 high temperature reading of $46^{\circ} \mathrm{C}$ was made in the summer on July 21,1962 , whereas, the much cooler West Mesa \#3 value of $24^{\circ} \mathrm{C}$ was recorded on February 18, 1974. Such a correlation casts considerable suspicion on bottom hole temperature data. Correspondence with personnel from logging companies has confimed the possibility that bottom hole thermometers may not have been properly centrifuged prior to insertion into a well. Such an operation is required to assure that the initial temperature reading on 
the thermometer is less than that in the well. The temperature on a hot July day can obviously exceed values in the borehole and the bottom hole temperature recorded on the well log may have nothing to do with the actual well temperature. In the future, special efforts should be made to insure reliable temperature data in municipal water wells. Dependable bottom hole values can form an extremely important, free data base which would otherwise be expensive and difficult to acquire.

In passing, it should be mentioned that the City of Albuquerque Department of Water Resources provided water temperature measurements obtained at many municipal well heads during flow tests. These data, which are presented in Appendix B, Table 1C, were originally compiled by Leonard Resources Inc. of Albuquerque in 1976. The use of these temperatures for geothermal evaluation was considered to be very limited after we found unexplainable descrepancies between these values and our own temperature logging program. For example, reported well head temperatures in the municipal San Jose field were 1 isted as $26.1^{\circ} \mathrm{C}$ in wells \#2 and 3 which are only 144 and $154 \mathrm{~m}$ deep, respectively. Our actual measurements in San Jose wells \#4, 5, 9, and 10 were all less than $22^{\circ} \mathrm{C}$ from the surface to as deep as $230 \mathrm{~m}$ depth (see below). Temperature Logging - Available Wells

The excellent cooperation of several public and private concerns enabled us to carryout a program of temperature logging in available water wells in the Albuquerque area. The cooperating groups are listed in the acknowledgements. The triangles on the map of Figure 20 show the locations of eight wells with measured depths of 30 to $100 \mathrm{~m}$ and seventeen wells exceeding $100 \mathrm{~m}$. Temperature data from these wells are plotted in Figures 21,22 , and 23. In most instances the wells were recently drilled water wells which had not yet been fitted with downhole 


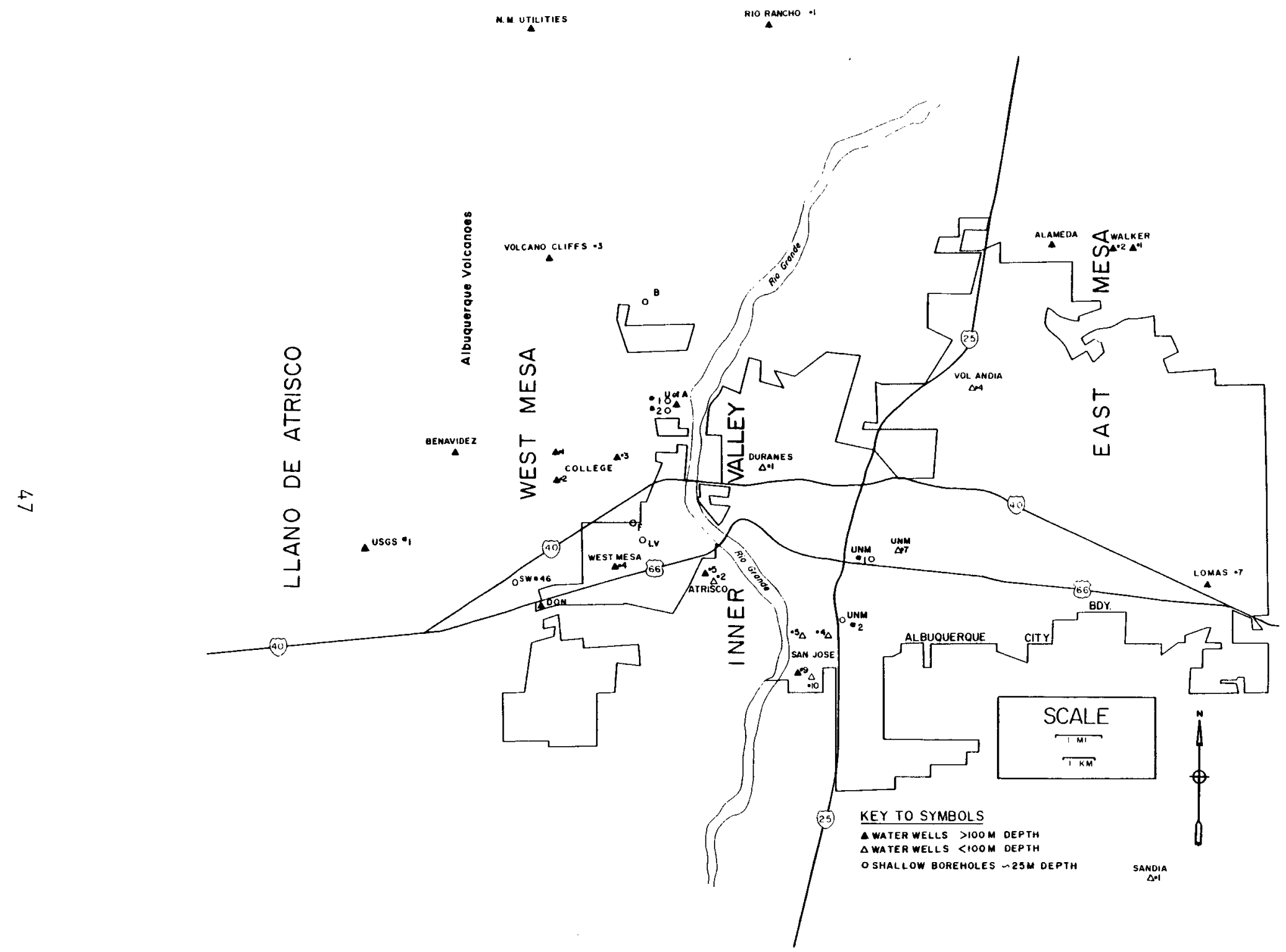

Figure 20. Location map showing 25 water wells (triangles) and 8 commercial drillholes (circles), exclusive of the Llano de Atrisco, which were temperature logged in Albuquerque area. 


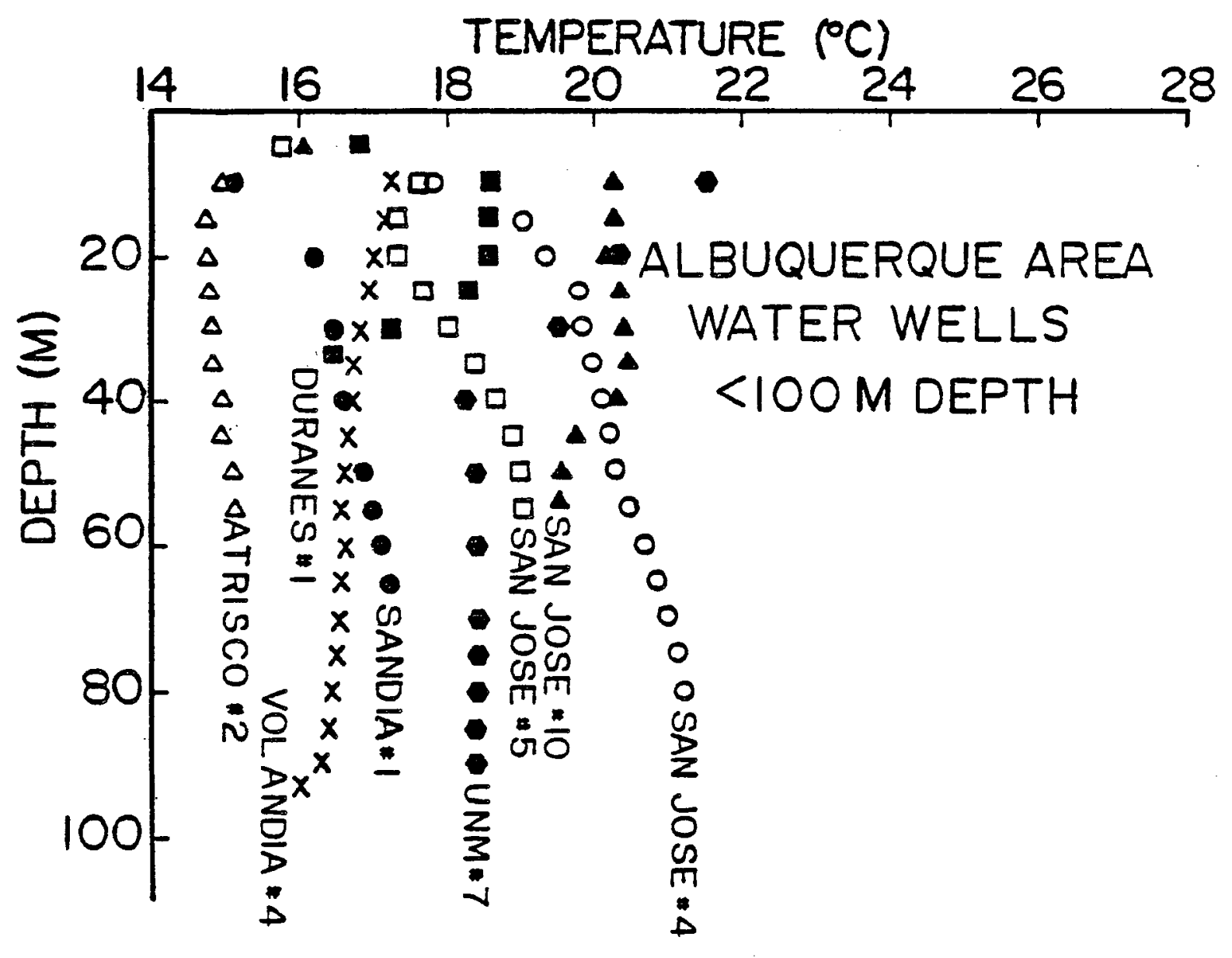

Figure 21. Temperature versus depth in water wells in Albuquerque with depths of less than $100 \mathrm{~m}$. 


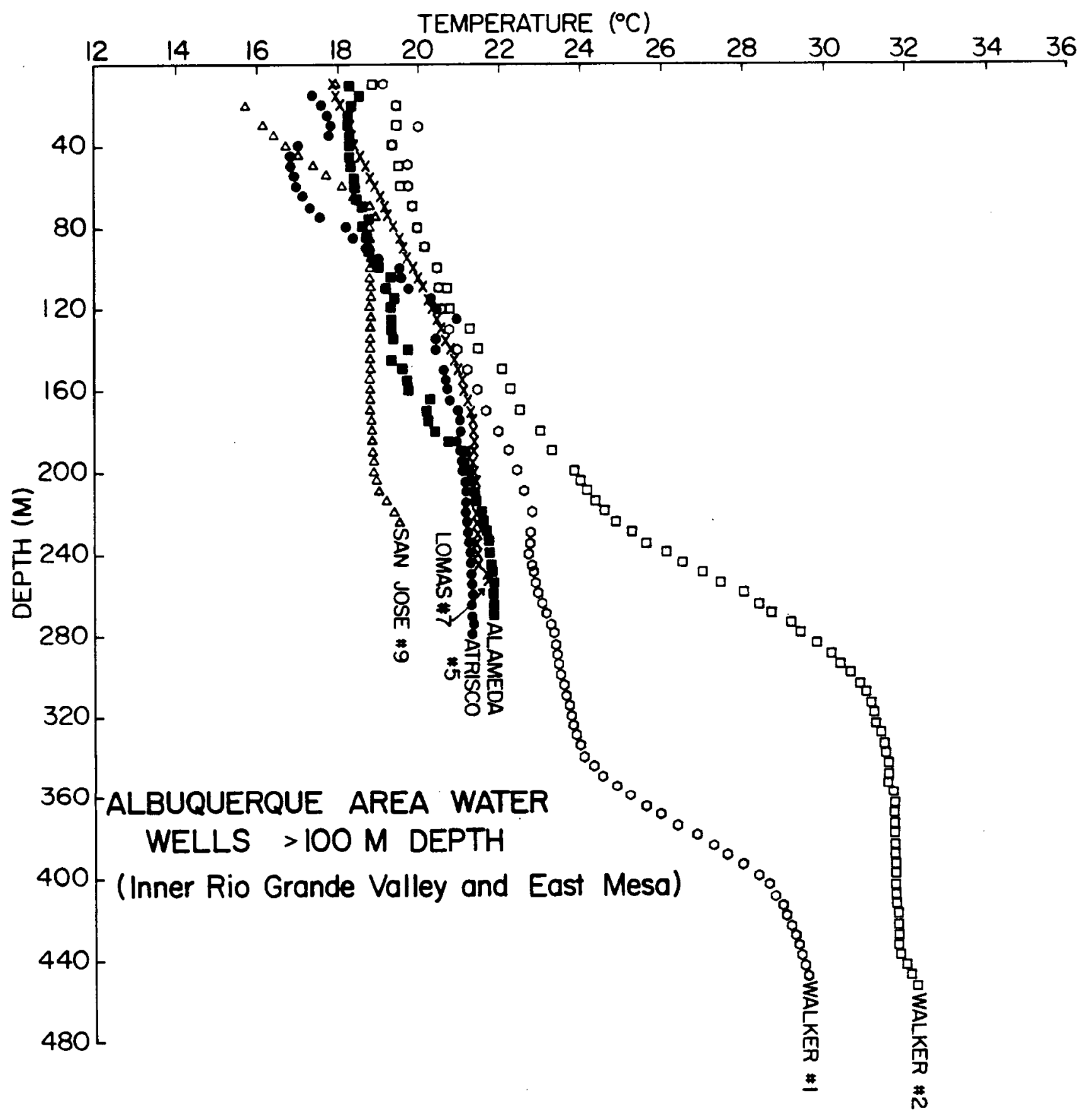

Figure 22. Temperature versus depth in water wells of greater than $100 \mathrm{~m}$ depth in the inner Rio Grande valley and East mesa areas of Albuquerque. 


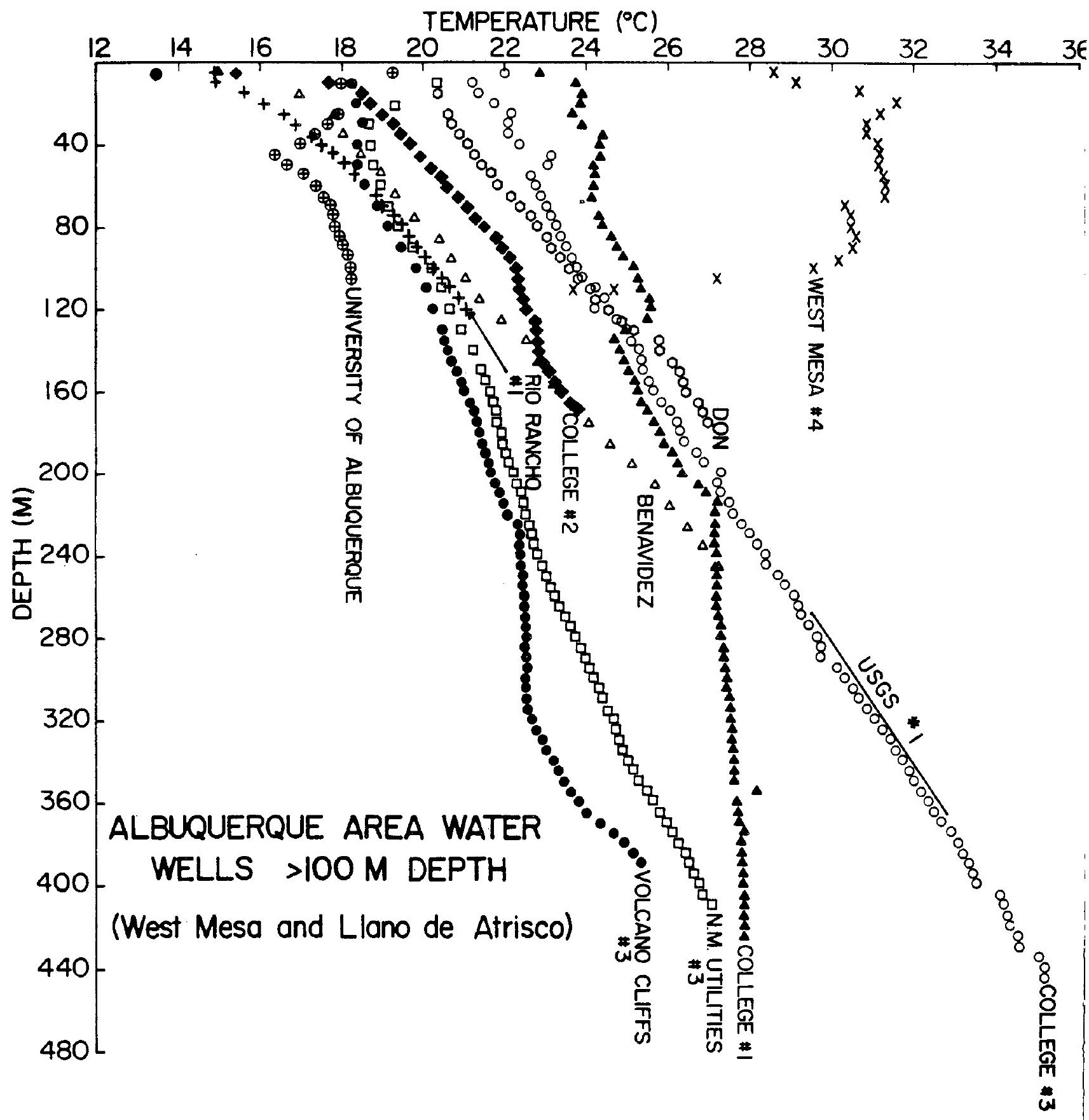

Figure 23. Temperature versus depth in water wells of greater than $100 \mathrm{~m}$ depth on the West mesa and Llano de Atrisco areas of Albuquerque. 
equipment, e.g. UNM \#7, Atrisco \#5, Walker \#1 and \#2, Volcano Cliffs \#3, NM Utilities \#3, College \#1 and \#3. In all of these cases, drilling had been completed a month or more before our measurements so the wells were close to equilibrium.

Some municipal water wells already in operation were accessed via a one inch diameter test port and monitoring tube running parallel to the well casing and extending to a depth just below the water table. At this point the tubes connect through the well casing into the well itself. A sharp bend in the tube at the connection prevented the penetration of our temperature probe into the main well. In all instances, except the measurement in West Mesa \#4, the wells had not been pumped for long periods of time so they were assumed to be in equilibrium.

The private Benavidez well is an abandoned stock water well and the University of Albuquerque well was measured during a time of removal and repair of the downhole pump. USGS \#1 result was measured by the U.S. Geological Survey in a water monitor well drilled in 1981; the line shown in Figure 23 is from continuous logging only below the water table $(268 \mathrm{~m})$ where the thermocouple probe was at the proper equilibrium temperature.

Our temperature measurements were made using thermister temperature probes. One tool had a depth capability of $100 \mathrm{~m}$; the other system had $440 \mathrm{~m}$ of cable. The latter unit is a high precision, high resolution instrument built by R. Spafford, of Mt. Baldy, California, for New Mexico State University. It is calibrated to $0.01{ }^{\circ} \mathrm{C}$. The shallow monitoring system is a commercial laboratory unit (Cole-Parmer Model 8502-20) which we extended for measurement to $100 \mathrm{~m}$. The thermister 
probe lists an accuracy of $\pm 0.57^{\circ} \mathrm{C}$ in the -30 to $+50^{\circ} \mathrm{C}$ range used in our work. The measurements are of higher precision; the digital output was displayed to $0.01^{\circ} \mathrm{C}$. All measurements above the water table, in air, represent values obtained by extrapolating eight minutes of recorded temperatures to their asymptotic values. Temperatures in water are actual readings since the themistor probes equilibrate within a few tens of seconds in water.

Figures 21, 22, and 23 present temperature versus depth values measured in twenty-five water wells in the Albuquerque area. The high variability in the surface temperatures $\left(\sim 13\right.$ to $28^{\circ} \mathrm{C}$ ) evident from extrapolating the curves to zero depth can be due to several effects. The highest value, at West Mesa \#4, is due to disturbance from recent pumping as discussed below. An overlying effect on all of the data is the decrease in ambient temperature with elevation (the adiabatic lapse rate) which we estimated to be about $10^{\circ} \mathrm{C} / \mathrm{km}$ in the area. The wells are within a range of $250 \mathrm{~m}$ elevation; therefore, other variables must influence the near-surface temperatures. Local disturbance due to ground-water movement and climatic perturbations may be important as well as other factors such as topography, soil moisture, vegetation, and evaporation rates (Roy et al., 1972; Blackwell et al., 1980; Lange et a1., 1982).

There is nothing noteworthy in the temperature gradient data measured at less than $100 \mathrm{~m}$, illustrated in Figure 21 . However, the results from both the Vol Andia and San Jose well fields discount the anomalously high temperatures reported from bottom hole temperatures (Figures 18 and 19) and pump tests in these well fields, respectively.

The highest temperatures within and east of the inner Rio Grande valley were measured at the Walker well field (Figures 20 and 22). Walker wells \#1 and \#2 are $5 \mathrm{~km}$ and $6 \mathrm{~km}$, respectively, from the bottom of the prominent front of the Sandia Mountains. Both wells in this 
field exhibit temperature gradients which deviate significantly below about $200 \mathrm{~m}$ (Figure 22). At Walker \#1 there is only a slight increase in temperature from $\sim 200$ to $350 \mathrm{~m}$ depth. Below this nearly isothermal zone, temperatures increase sharply $\left(\sim 80^{\circ} \mathrm{C} / \mathrm{km}\right)$ to about $420 \mathrm{~m}$ depth and then return to around $30^{\circ} \mathrm{C} / \mathrm{km}$ as above $200 \mathrm{~m}$. At Walker \#2, situated about $1 \mathrm{~km}$ west of well \#1, the high gradient zone is shallower, from about 200 to $300 \mathrm{~m}$, and the well is nearly isothermal below this zone.

By linearly extending the shallow (<200 m) gradients in Walker wells $\# 1$ and \#2 (Figure 22) it is evident that the deepest portions (>400 $\mathrm{m}$ and $>440 \mathrm{~m}$, respectively) fit the extrapolated shallow gradients. This permits us to recognize the anomalous regions in each well as a cooling influx of water in Walker \#l from $\sim 220 \mathrm{~m}$ to $400 \mathrm{~m}$ and a warm flow of water affecting Walker \#2 from $\sim 220 \mathrm{~m}$ to $440 \mathrm{~m}$.

A possible cause for these trends is hydraulically forced convection (Harder et al., 1980; Morgan and Daggett, 1981). Cold water moving westward from the Sandia Mountains over buried, impermeable fault blocks extending west of the visible front descends rapidly after traversing this bench (Figure 5). The cooling trend observed from $220 \mathrm{~m}$ to $400 \mathrm{~m}$ in Walker \#1 may reflect this cool descending flow. Hydraulic pressure produced by the descending cold water would displace water heated in a normal thermal gradient upward to the west. Such a mechanism could force warmer water to shallower than normal depths (220 to $440 \mathrm{~m}$ depth) at Walker well \#2.

All of the observed water wells in the inner Rio Grande valley and on the East mesa have nearly isothermal zones although the Walker wells are clearly warmer at corresponding depths (Figure 22). Temperature gradients in water wells near the Rio Grande, such as Atrisco \#5 and San 
Jose \#9, are undoubtedly influenced by shallow ground-water movement. A nearly constant temperature gradient of $20^{\circ} \mathrm{C} / \mathrm{km}$ is evident above the water table ( $180 \mathrm{~m}$ depth) at the easternmost well logged in our study, Lomas \#7 (Figure 18). The decrease in gradient below the water table is probably due to water movement (convection) and an increase in thermal conductivity in the saturated zone. Conductive heat flow is the product of the thermal conductivity of the material and the thermal gradient. Consequently, for a constant conductive heat flow, an increase in thermal conductivity is accompied by a decrease in temperature gradient.

Temperature measurements west of the Rio Grande (Figure 23) are generally higher at corresponding depths than those to the east (Figure 22). For example, nearly all well data plotted in Figure 23 exhibit temperatures greater than $22^{\circ} \mathrm{C}$ at $200 \mathrm{~m}$ depth whereas in Figure 22 the corresponding values are nearly all less than $22^{\circ} \mathrm{C}$. West Mesa well \#4 had the highest water discharge temperature of any operating well measured in our program, $32.1^{\circ} \mathrm{C}$. This was higher than West Mesa well \#1 $\left(26.5^{\circ} \mathrm{C}\right)$ which had been listed by Bjorklund and Maxwell (1961) at $32^{\circ} \mathrm{C}$. Temperature measurements in the test port of West Mesa \#4 from the surface to over $100 \mathrm{~m}$ depth are highly distorted (Figure 23) due to pumping prior to our measurements. To better assess the undisturbed temperature distribution at West Mesa \#4, the well was shut down and monitored over a two week period. The systematic decrease in temperature values above $100 \mathrm{~m}$ during this time interval indicated the influence of deep, warm water brought to the surface during pumping. The well has a total depth of $\sim 440 \mathrm{~m}$; the water table is at about $55 \mathrm{~m}$. The highest water temperature measured in our program in the 
Albuquerque area was $35.1^{\circ} \mathrm{C}$ at $445 \mathrm{~m}$ depth at municipal College \#3 well. The gradient from the water table $(\sim 90 \mathrm{~m})$ to this level was a nearly constant $33^{\circ} \mathrm{C} / \mathrm{km}$. U. S. Geological Survey well \#1 (Figures 20 and 23) exhibited a slightly higher gradient below the water table of $35^{\circ} \mathrm{C} / \mathrm{km}$ and the highest temperature $\left(32.8^{\circ} \mathrm{C}\right)$ in the Albuquerque area at $364 \mathrm{~m}$ (the maximum depth, Figure 23). The siting of this well on the Llano de Atrisco (Figure 20) was determined with our cooperation. The subsequent section on the Llano de Atrisco describes the relation of this well and our temperature gradient drilling program on the Llano.

Our deep downhole measurements in municipal water wells shown in Figures 22 and 23 allowed us to evaluate the corresponding bottom hole temperatures from well logs (Table 4 and Figure 18). In all cases we have observed a perplexing disagreement. Consider the following examples: 1) our measurement of College \#3 is $35^{\circ} \mathrm{C}$ at $444 \mathrm{~m}$ depth, well logs gave $28^{\circ} \mathrm{C}$ at $454 \mathrm{~m} ; 2$ ) our measurement of the Don well gave $27^{\circ} \mathrm{C}$ at $160 \mathrm{~m}$, well logs gave $27^{\circ} \mathrm{C}$ at $490 \mathrm{~m}$; 3) our deepest measurement in Volcano Cliffs $\# 3$ yielded $26^{\circ} \mathrm{C}$ at $400 \mathrm{~m}$, well logs gave 46 and $49^{\circ} \mathrm{C}$ at $502 \mathrm{~m}$. The latter value would require a gradient of nearly $200^{\circ} \mathrm{C} / \mathrm{km}$ in Volcano Cliffs \#3 below our final $400 \mathrm{~m}$ depth. These examples illustrate serious problems with bottom hole temperatures recorded on geophysical logs. The importance of making proper temperature measurements as a function of depth is clearly emphasized. Temperature Logging - Drilled Holes

A major part of our geothermal evaluation project in the Albuquerque area was the drilling, completing, and logging of shallow temperature gradient holes. During the duration of our project we drilled 69 holes; the maximum depth was $53 \mathrm{~m}$. Most holes were drilled to provide $25 \mathrm{~m}$ temperature measurement holes. 
The drilling activities began in July, 1979, with the positioning of eight holes (AI through A8), the locations of which are shown in Figure 24. The temperature versus depth results of these initial wells are given in Appendix $A$. Boreholes $A 1, A 2$, and $A 3$ were positioned near municipal West Mesa wells \#4,2, and 1, respectively. The remaining five holes were located in an area which we designated as the Llano de Atrisco. This area is discussed in detail in a subsequent section.

Boreholes Al-A8 were drilled by personnel from New Mexico State University using a shallow, portable drilling tool (Deep Rock Hydrodrill). This system was not well suited for drilling holes greater than $15 \mathrm{~m}$ since progress was slow and collapse of the $17 / 8$ " diameter hole often occurred. Consequently, only five holes (A1, A2, A3, A4, and A7) provided the minimum depth range of $15-20 \mathrm{~m}$ considered necessary to obtain a gradient free from the influence of the annual temperature wave. These temperature gradients $\left(88,60,73,60\right.$, and $\left.75^{\circ} \mathrm{C} / \mathrm{km}\right)$ were considerably higher than the measured deeper gradients (e.g. Figures 21 , 22, and 23); this, we discovered, is a characteristic of nearly all shallow gradients in the Albuquerque area. The phenomenon is due to the lower thermal conductivity in the near-surface material which is relatively less compacted and drier than deeper sediments. Therefore, these high temperature gradients do not represent enhanced heat flow. Subsequent drilling established that a shallow gradient $(<25 \mathrm{~m})$ of about $60^{\circ} \mathrm{C} / \mathrm{km}$ represented the background, or average value, above the water table on the western side of Albuquerque. All temperature measurements in drillholes Al-A8 were made in 1 inch diameter PVC pipe capped at the bottom, inserted in the holes, and filled with water. Equilibrium temperatures were achieved after the holes sat for several days. 


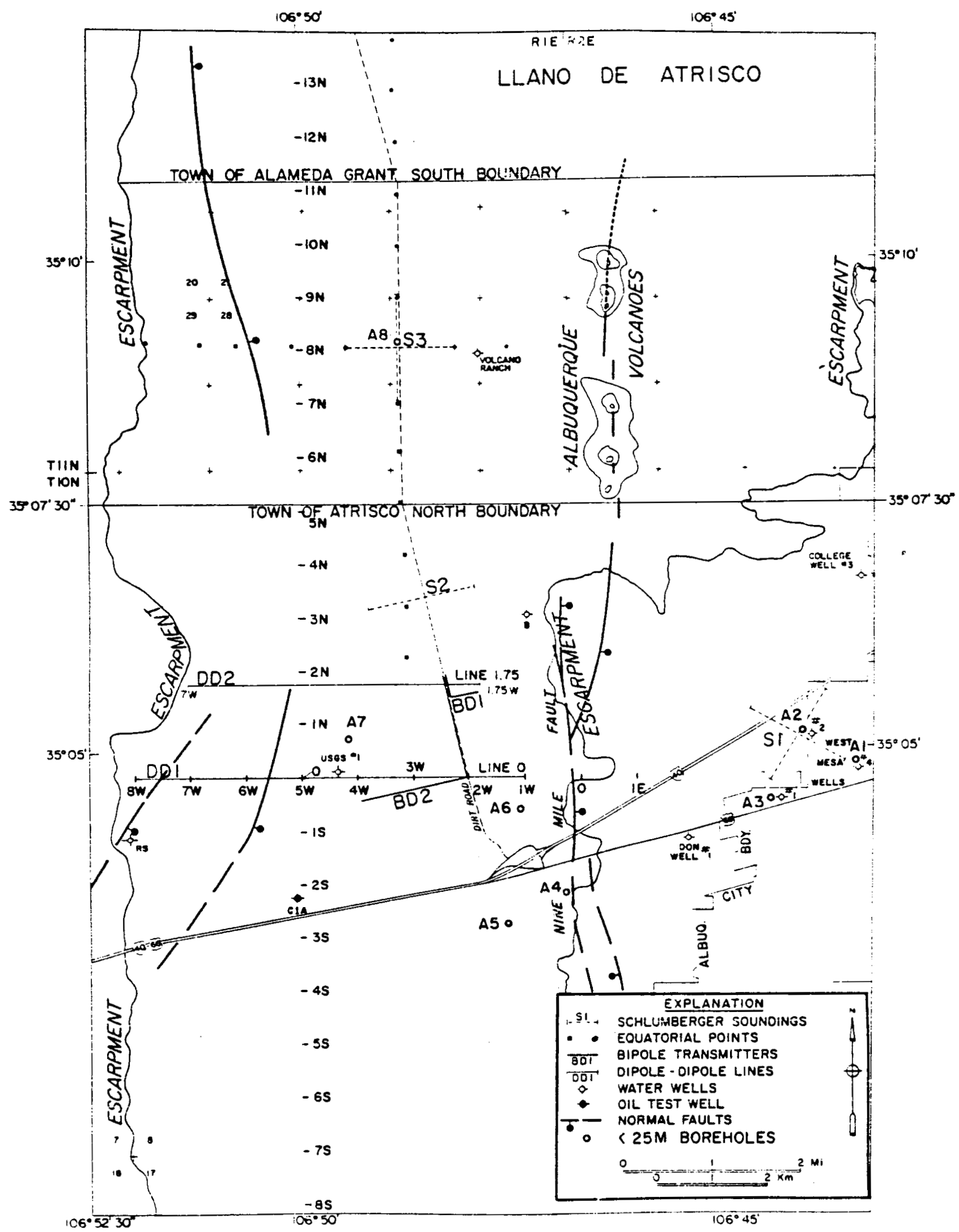

Figure 24. Location map of West mesa and Llano de Atrisco showing 8 holes (A1 - A8) drilled in 1978 by New Mexico State University. 
After concluding that the shallow temperature gradients provided useful data, an extensive shallow drilling program was initiated using commercial drillers. Most holes were drilled on the Atrisco land grant, a large ( 50,000 Ac), mostly undeveloped area near the West Mesa well field which extends beyond the Albuquerque volcanoes (Figure 24). Shallow gradient well A7, which measured the second highest gradient of the initial wells $\left(75^{\circ} \mathrm{C} / \mathrm{km}\right)$, is located in a very accessible area of the land grant which we subsequently named the Llano de Atrisco (Parker and Jiracek, 1980). The accessibility of this area allowed us to set up a 1 $\mathrm{km}$ by $1 \mathrm{~km}$ grid of gradient holes over much of the area (Figure 24). Some shallow gradient values well in excess of $100^{\circ} \mathrm{C} / \mathrm{km}$ were discovered during the drilling program. This and other factors previously mentioned precipitated a combined geophysical assessment of the Llano de Atrisco.

All boreholes drilled by commercial drillers were 4 inches in diameter and drilled to at least $25 \mathrm{~m}$ depth. Some cave-in of the holes resulted in reduced depths in some instances. Holes were fitted with $3 / 4$ inch water-filled polyethylene tubes which permitted rapid equilibrium temperature measurements from the surface to the capped bottom of the tubes. All boreholes were above the water table, in aerated alluvium or aeolian deposits.

All temperature measurements, including in some instances several remeasurements in the same hole, are shown by graphs in Appendix $A$. Besides the 53 holes drilled commercially on the Llano de Atrisco, eight additional holes were drilled at other sites (Figure 20) chosen for various reasons. Two holes each were drilled on property of the University of Albuquerque ( $U$ of $A \# 1$ and \#2) and the University of New 
Mexico (UNM \#1 and \#2). Both universities are interested in the possible usage of geothermal fluids (Kauffman and Houghton, 1979; 1980); however, it is evident from the data shown in Appendix A that the shallow gradients at these sites exhibit low temperature gradients (0 to $\left.55^{\circ} \mathrm{C} / \mathrm{km}\right)$. Two additional gradient holes were drilled in the vicinity of the City of Albuquerque's West Mesa well field, on Fortuna Road (F) and Los Volcanes (LV) Road (Figure 20). The gradients are 71 and $78^{\circ} \mathrm{C} / \mathrm{km}$ at these locations, respectively. Another well was drilled on the private property of $G$. Bennett (B) just below the eastern scarp of the lava flows of the Albuquerque volcanoes and well SW \#46 was located $1 \mathrm{~km}$ northwest of the Don municipal water well (Figure 20). Neither well exhibited unusual results (Appendix $A$ ).

The 53 commercial holes drilled on the Llano de Atrisco permitted gradient patterns to be contoured and two anomalously high $\left(>100^{\circ} \mathrm{C} / \mathrm{km}\right)$ zones to be identified. The temperature versus depth results from these measurements and a complete discussion of the area, including the application of other geophysical techniques, appear in the later section on the Llano de Atrisco Anomaly.

\section{Geothermometry}

The essence of geochemical methods in geothermal exploration and evaluation is that the solubility of various ions (or ratios of ions) is temperature dependent and that the dissolved concentrations become established within the geothermal reservoir and do not change as the water migrates to the surface sampling point. Thus by plotting the concentrations (or ratios) of ions against known reservoir temperature, 
empirical curves can be established which relate concentrations (or ratios) to reservoir temperature. This technique is known as geothermometry and is discussed in detail by Truesdell (1976). The two most commonly accepted geothermometers are the silica and the $\mathrm{NaKCa}$ geothermometers, and we will restrict our analysis herein to these geothermometers.

The most common use of geothermometers is to apply them to hot spring waters to estimate reservoir base temperature. However, Swanberg (1975) has shown that the geothermometers can al so be applied to non-thermal waters and the results used to detect the presence of a geothermal component in ground waters. While this method is not necessarily a quantitative way to estimate subsurface temperatures, it is a very rapid and inexpensive way to search for geothermal resources. The technique of using geothermometry in geothermal exploration is discussed by Swanberg and Alexander (1979) and using their results, we have established the following criteria for recognizing geothermal waters in the Albuquerque area: silica geotemperatures (SIT) must be in excess of $120^{\circ} \mathrm{C}$ and $\mathrm{NaKCa}$ geotemperatures (CHT) must be in excess of $100^{\circ} \mathrm{C}$.

Chemical analyses of 88 samples of ground water taken from the files of the City of Albuquerque Department of Water Resources (47 samples), the U. S. Geological Survey (23 samples), and our own field sampling (18 samples) were used in the geochemical study. Appendix B, Table 1 gives the geochemical temperatures predicted by the silica and $\mathrm{NaKCa}$ geothermometers and the Mg corrected version of the NaKCa geothermometer (Fournier and Potter, 1979), along with the sample locations and 
temperatures. The corresponding chemical data are given in Appendix $B$, Table 2. The sample locations are plotted in Figure 25 and those samples which are geochemically "hot" are designated. It is clear that the sample distribution is less than ideal. The samples from the city wells and from the U.S.G.S. WATSTORE file are concentrated in the eastern part of the map area. In the western part of the map area, where the geothermal resources are most likely located, the majority of samples had to be collected and analyzed as part of the present study and their geographic distribution reflects the paucity of available water wells in this area. Despite the small amount of geochemical data in the most critical part of the study area, we can still draw the following conclusions:

1) The most promising prospect area sampled is located between the Rio Grande and the Albuquerque volcanoes. Waters from these wells yield silica geotemperatures of $140^{\circ} \mathrm{C}$ and $\mathrm{NaKCa}$ and $\mathrm{NaKCa} \mathrm{Mg}$ geotemperatures as high as $190^{\circ} \mathrm{C}$. Unfortunately, the high geochemical temperatures as depicted by the two geothermometers do not represent the same sample so that the data must be regarded as contradictory.

2) In the Llano de Atriso area of high geothermal gradients $\left(>100^{\circ} \mathrm{C} / \mathrm{km}\right)$ as depicted by shallow test hole drilling (Appendix A) there were no water wells available for sampling so the existence of this anomaly cannot be confirmed geochemically.

3) There are several city wells located between the Rio Grande and Interstate 25, which give abnormally high silica geotemperatures (Figure 25). However, these same wells give normal values of $\mathrm{NaKCa}$ geotemperatures so that this area cannot be confirmed as a geothemal prospect.

4) There is no geochemical data to suggest any geothermal resources east of Interstate 25 (Figure 25). 


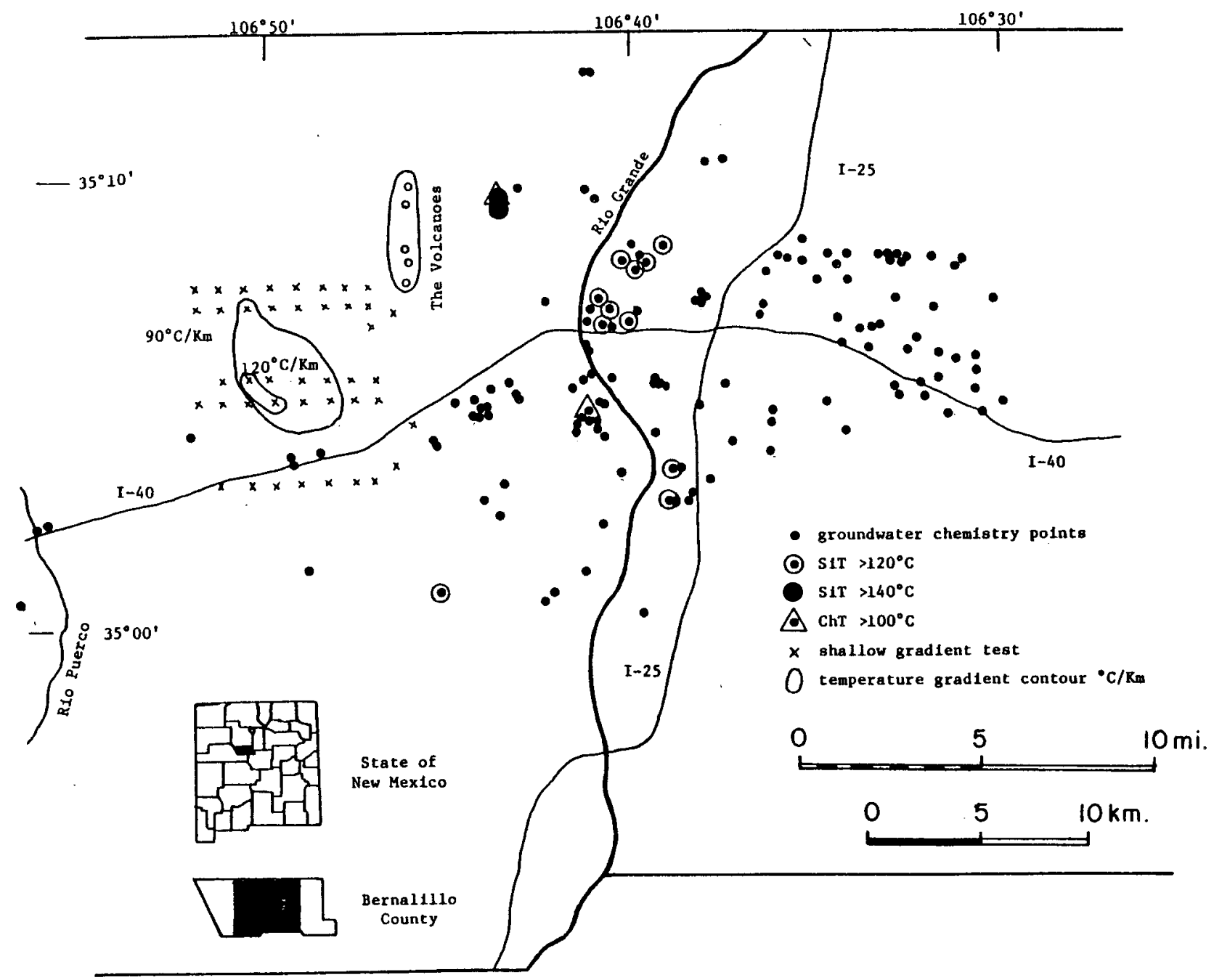

- Figure 25. Location map of Albuquerque area, Bernalillo County showing locations of ground waters used for geochemical analyses. 
Figure 26 shows the available heat flow data from Bernalillo County (Reiter et al., 1975). As discussed earlier, the mean value of the 14 points shown in Figure 26 is $84 \pm 25 \mathrm{~mW} / \mathrm{m}^{2}(2.0 \pm 0.6 \mathrm{HFU})$. However, there is a definite trend in the data. The six western heat flow values average $105 \pm 17 \mathrm{~mW} / \mathrm{m}^{2}(2.5 \pm 0.4 \mathrm{HFU})$, whereas the eight eastern values average only $63 \pm 13 \mathrm{~mW} / \mathrm{m}^{2}(1.5 \pm 0.3 \mathrm{HFU})$. Reiter et al. (1975) noted this trend along the entire length of the Rio Grande rift and contoured the zone of maximum heat flow to coincide with the western margin of the rift.

The silica heat flow method of Swanberg and Morgan (1980) has also been applied to the study area in the hope of providing a more uniform heat flow coverage than is provided by the 14 widely distributed traditional points (Figure 25). Unfortunately, the silica data are highly scattered and do not meet the statistical criteria necessary for application of this technique. Part of the scatter may result from the fact that the silica data were obtained from different sources. Values of silica heat flow obtained using the data from the municipal water wells average $138 \mathrm{~mW} / \mathrm{m}^{2}$ (3.3 HFU), a value which is not only unrealistically high, but which is also 50 percent higher than either of the other two data sets used in the study. Thus, these data are suspect. The scatter may also result from the fact that the area is hydrologically complex and a similar situation has been discussed by Swanberg and Morgan (1980) in the southern Rio Grande rift of New Mexico. 


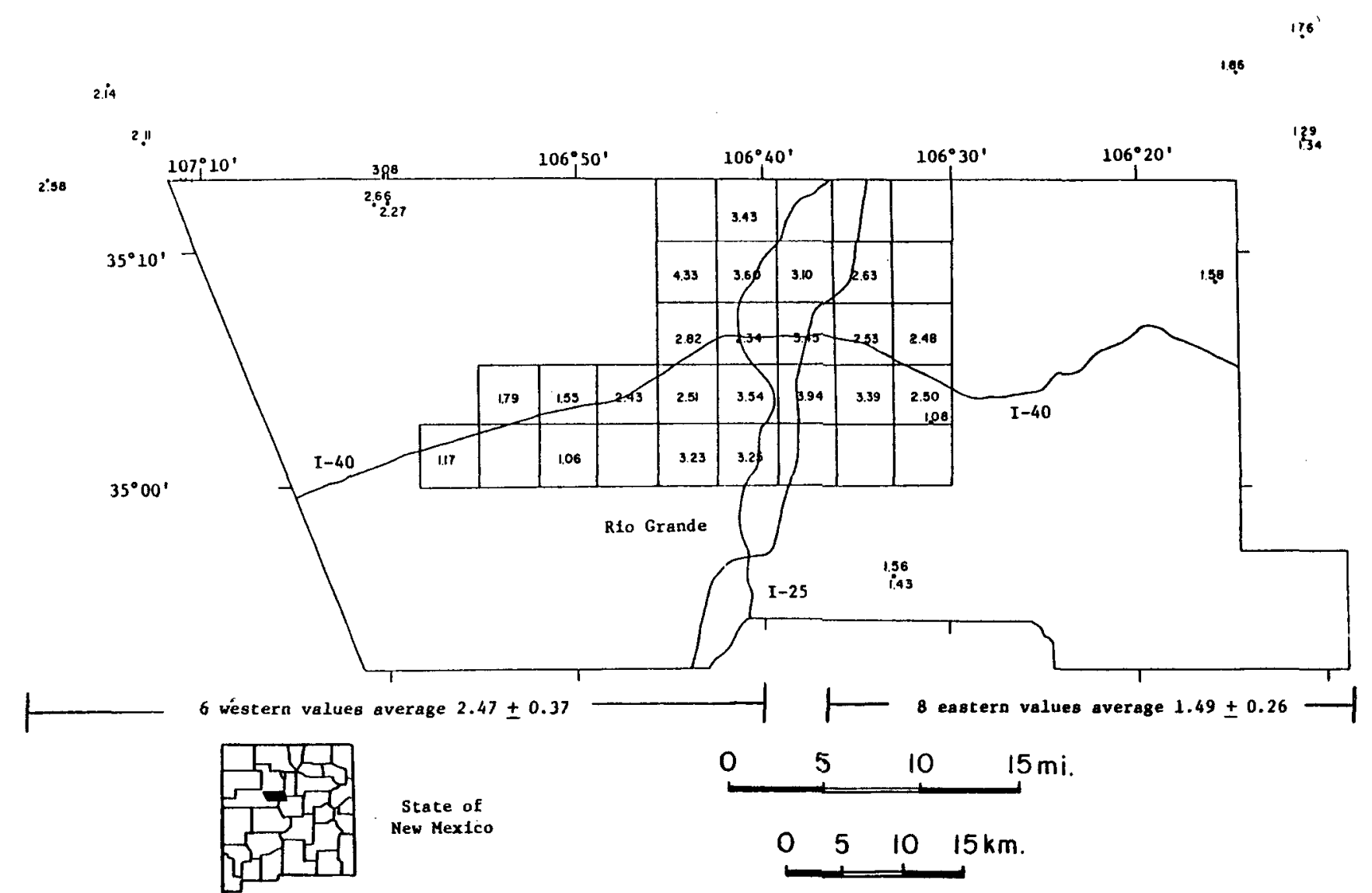

Figure 26. Location map of Albuquerque area, Bernalillo County showing heat flow data. Numbers near dots are traditional heat flow values (Reiter et al., 1975). Numbers in blocks are silica predicted heat flow values. Heat flow values in HFU. 
The silica heat flow values averaged over quarter townships are also shown in Figure 26. The highest values are located in the central map area and reflect the distribution of the municipal well data rather than a regional trend in silica content. The silica method does not appear to reflect the east-west trend observed in the traditional heat flow data although a much larger and more reliable data set is needed before this statement can be confirmed. Using all silica data listed in Appendix $B$, Table 1 the silica heat flow method predicts a regional heat flow of $122 \mathrm{~mW} / \mathrm{m}^{2}(2.9 \mathrm{HFU})$ for the Albuquerque basin. If the municipal well data are eliminated from the data set, then the silica method predicts a more reasonable value of $101 \mathrm{~mW} / \mathrm{m}^{2}$ (2.4 HFU) for the basin. This value must be considered as an estimate since the data set is too small to obtain a statistically reliable silica heat flow.

\section{RESISTIVITY METHODS IN GEOTHERMAL EXPLORATION}

Electrical resistivity methods were extensively used west of Albuquerque in a potential geothermal area called the Llano de Atrisco anomaly (discussed in the next section). This section provides an introduction to the basic aspects of using d.c. resistivity in the exploration for hydrothermal resources. There are several reasons why low electrical resistivity is expected in hydrothermal aquifers but the association is not without pitfalls. From the outset one should understand that the actual complex hydrogeological situation undergoes a simplifying transformation in the face of resolution and modeling capabilities in resistivity. Figure 27 illustrates a hydrothermal target which is a thermal aquifer perhaps first detected by a warm well. 


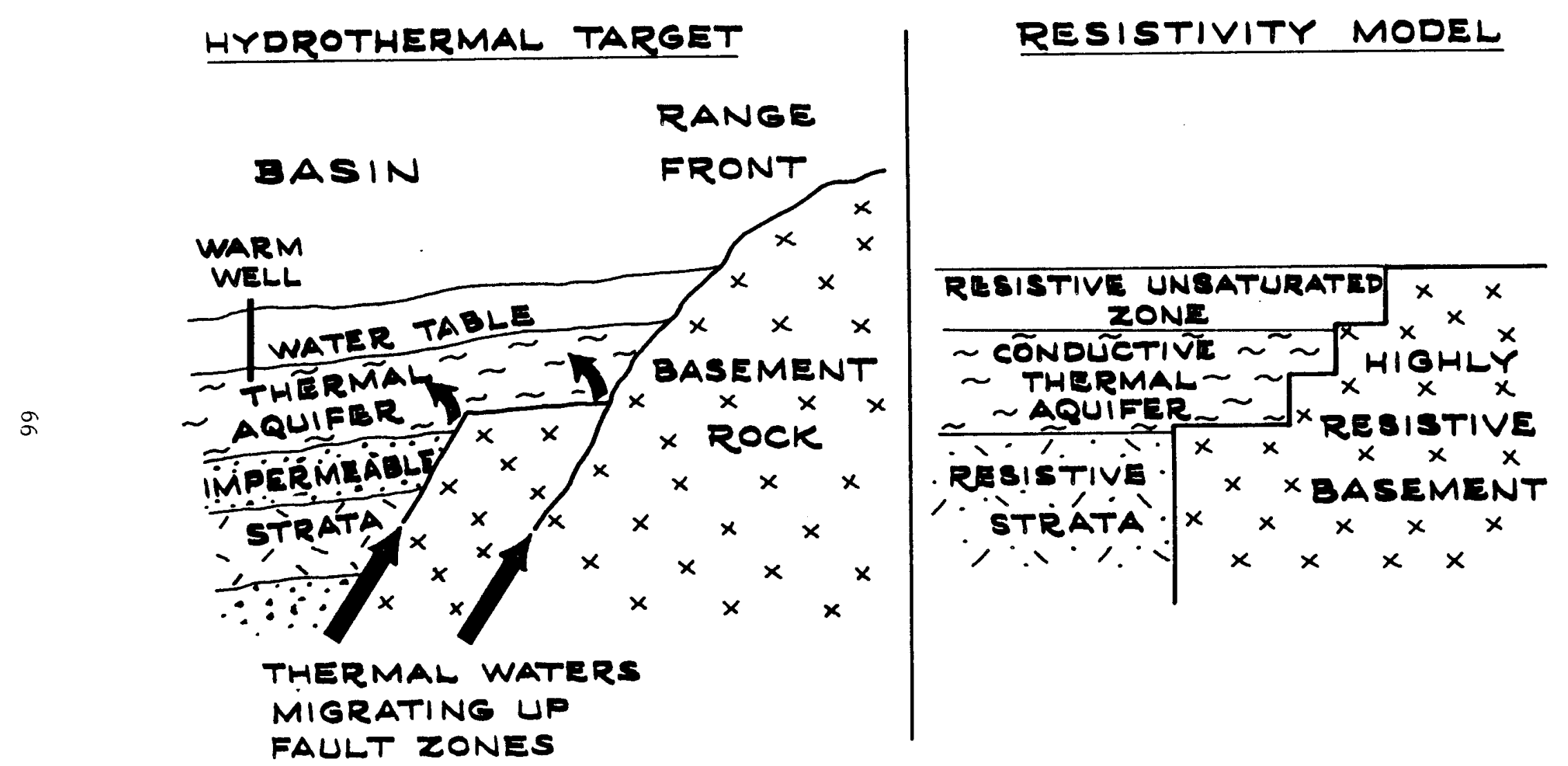

Figure 27. Schematic of possible hydrothermal target and corresponding resistivity model. 
The plumbing system may be some complicated migration of thermal waters up various fault zones. We visualize this situation as a resistivity model with a conductive slab approximating the aquifer which is surrounded by electrically resistive blocks. Rarely can the plumbing system be seen with resistivity and usually surface topography is not considered. Dipping fault contacts are usually modeled as stepped resistivity boundaries (Figure 27 )

The two major uses of resistivity measurements in hydrothermal exploration are outlined in Figure 28 as: 1) detection and delineation of aquifers and 2) estimation of aquifer temperature and water content. First, and foremost, is the detection and delineation of aquifers. Here, the key property is that hydrothermal aquifers have low resistivity. This is true because of the inherent effect of water itself coupled with the temperature-resistivity dependencies of ion mobility, salinity, and hydrothermal mineral alteration. Despite all of these factors favoring the association of low resistivity with hydrothermal resources we are cautioned (Figure 28) that nonthermal clay zones may have d.c. resistivities indistinguishable from hydrothermal aquifers. This warning cannot be overemphasized; it is the most serious limitation regarding the identification of a thermal aquifer with resistivity alone. High salinities common in nonthermal marine sediments and restricted basin systems may also falsely indicate a geothermal target. Thermal confirmation such as a warm well, a hot spring, or a high thermal gradient is necessary to connect low resistivity with a thermal anomaly. 


\section{USE OF RESISTIVITY IN HYDROTHERMAL EXPLORATION}

\section{DETECTION AND DELINEATION OF AQUIFERS}

\section{HYDROTHERMAL AQUIFERS HAVE LOW RESISTIVITY BECAUSE:}

1. Water Decreases Resistivity

2. Increased temperature Decreases Resistivity of Water (Increased Ion Mobility)

3. Increased Water Temperature Increases Salinity by Dissolving More Minerals Which Decreases Resistivity (Increased Number of Charge Carriers)

4. Hydrothermal Alternation Minerals Decrease Resistivity (e.g. Igneous Rocks into Clay and Zeolites)

WARNING: Nonthermal Clay Zones May Have Resistivities Indistinguishable from Hydrothermal Aquifers.

\section{ESTIMATION OF AQUIFER TEMPERATURE AND WATER CONTENT}

LOWER RESISTIVITY IMPLIES HIGHER TEMPERATURE POROSITY ESTIMATION BY ARCHIE'S LAW

$$
\begin{aligned}
& \frac{\rho_{\mathrm{R}}}{\rho_{w}} \simeq \Phi^{-2} \\
& \text { Pr: Resistivity of }
\end{aligned}
$$

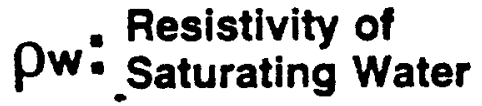

$$
\begin{aligned}
& \Phi \text { : Fractional Porosity }
\end{aligned}
$$

WARNING: Archie's "law" is Empirically True for Clay-Free Aquifers Only.

Figure 28. Use of resistivity in hydrothermal exploration. 
The second application of resistivity is in the estimation of aquifer temperature and water content. Simply stated, lower resistivity implies higher temperature; however, quantitative relationships between fluid resistivity and temperature often yield incorrect temperature estimates in practice. Again, the presence of clay in the hydrothermal aquifer will produce erroneous results. An estimate of the amount of water-filled porosity can be accomplished by using some form of Archie's law. The simplist form of the equation is given in Figure 26. Here, a surface measurement of the resistivity of the saturated aquifer $\left(\rho_{R}\right)$ is coupled with the resistivity value of the saturating fluid $(\rho, W)$, e.g. obtained from a spring or well, to compute the fractional porosity, . Clay is again the major problem in such a calculation since Archie's relationship is really not a "law" but is empirically true for clay-free aquifers only.

Resistivity techniques can be described by three categories as listed in Figure 29. These are: 1) vertical sounding accomplished by expanding an array and effectively sensing to greater depths, 2) horizontal profiling using a constant array spacing moved laterally along the surface, and 3 ) a combination of sounding and profiling to produce either a section or a map. Various electrode arrays are used to accomplish these purposes; the Wenner, Schlumberger, equatorial, dipole-dipole, and bipole-dipole arrays are the most common. The resistivity study of the Llano de Atrisco included in the next section of this report presents examples of one-dimensional (vertical) sounding, two-dimensional sounding-profiling producing a resistivity pseudosection, and bipole-dipole mapping allowing a three-dimensional interpretation. 
RESISTIVITY TECHNIQUES AND COMMON ARRAYS

1. VERTICAL SOUNDING (1-D) WENNER, SCHLUMBERGER, EQUATORIAL ARRAYS

2. HORIZONTAL PROFILING (LIMITED 2-D) WENNER, SCHLUMBERGER ARRAYS

3. COMBINED SOUNDING - PROFILING PSEUDOSECTION (2-D)

WENNER, SCHLUMBERGER, DIPOLE-DIPOLE ARRAYS

MAPPING (3-D)

BIPOLE-DIPOLE (ROVING DIPOLE) ARRAY

Figure 29. Resistivity techniques and common arrays.

\section{COMMON RESISTIVITY ARRAYS}

COLLINEAB

WENNER ARRAY

$M N=\frac{A B}{3}$
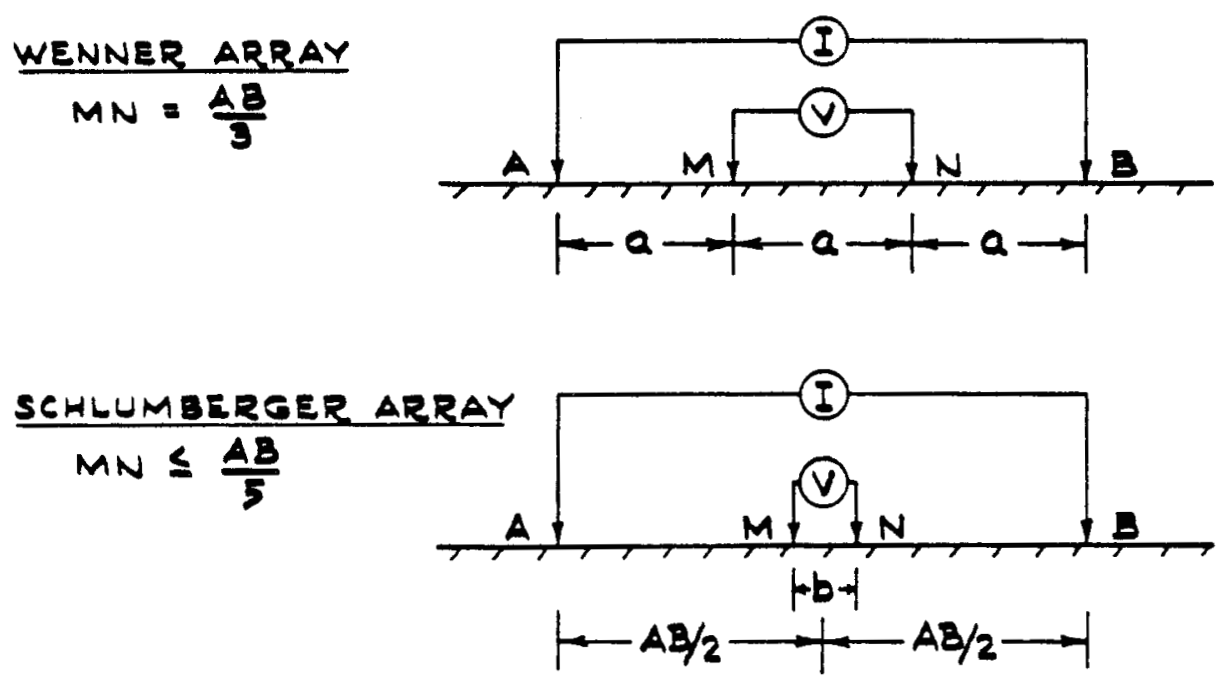

TRANSMITTER RECEIVER

DIPOLE - DIPOLE ARRAY $n=1,2,3, \cdots$

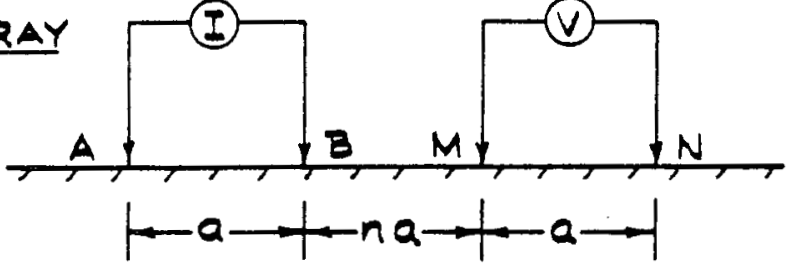

Figure 30. Common collinear resistivity arrays. 
The common arrays where the voltage and current electrodes are emplaced in a collinear fashion are the Wenner, Schlumberger, and dipole-dipole arrays (Figure 30 ). Probably the best-known array is the Wenner array which has four equally spaced contacts with the earth; current is usually passed through the two outer electrodes ( $A$ and $B$ ) and the resulting voltage drop is measured by the inner electrode pair ( $M$ and $N$ ). The Schlumberger array uses the MN electrodes much closer together, less than one-fifth the outer $(A B)$ spacing. The dipole-dipole array separates the current transmitting dipole (AB) from the voltage receiving dipole (MN) by integer multiples of the dipole spacing (a). The dipole-dipole technique is very sensitive to subsurface lateral resistivity boundaries and it was for this purpose that it was applied on the Liano de Atrisco.

There are two common areal resistivity arrays shown in plan views in Figure 31. In the equatorial array the voltage measuring $M N$ electrodes are maintained parallel to a fixed $A B$ current source but are, additionally, moved along the perpendicular bisector (or equator) of $A B$. It is obvious that the equatorial array is identical to the Schlumberger array (Figure 30) in the limiting case when $M N$ is between $A B$, providing $M N \leq A B / 5$. The bipole-dipole technique in Figure 31 employs a long, fixed $A B$ current source called a bipole to distinguish it from the much shorter MN voltage measuring dipoles. Usually two voltage dipoles (Figure 31) are used to calculate the gradient of the potential at each location which is the total vector electric field. The bipole-dipole method is also called roving dipole since voltage measurements are made by roving about the fixed current source. 


\section{AREAL}
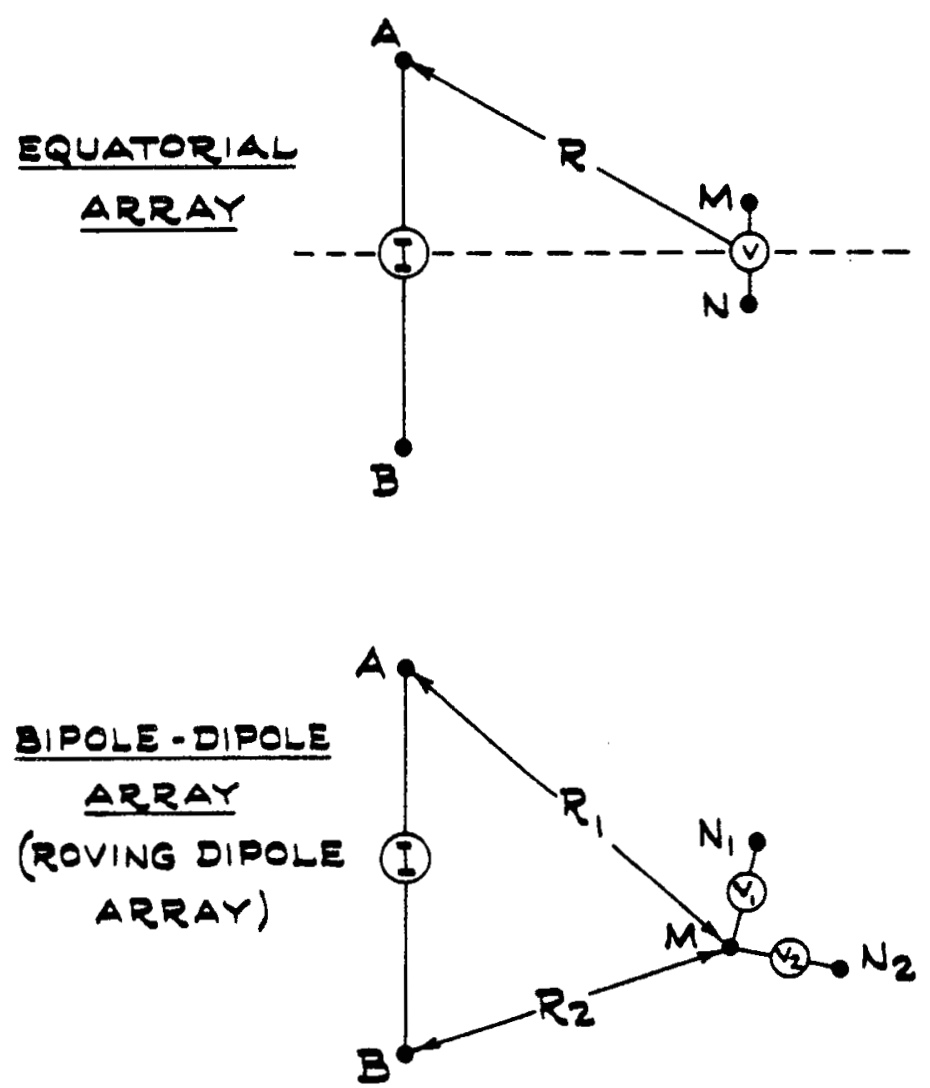

Figure 31. Common areal resistivity arrays.

\section{DIPOLE-DIPOLE PLOTTING METHOD}
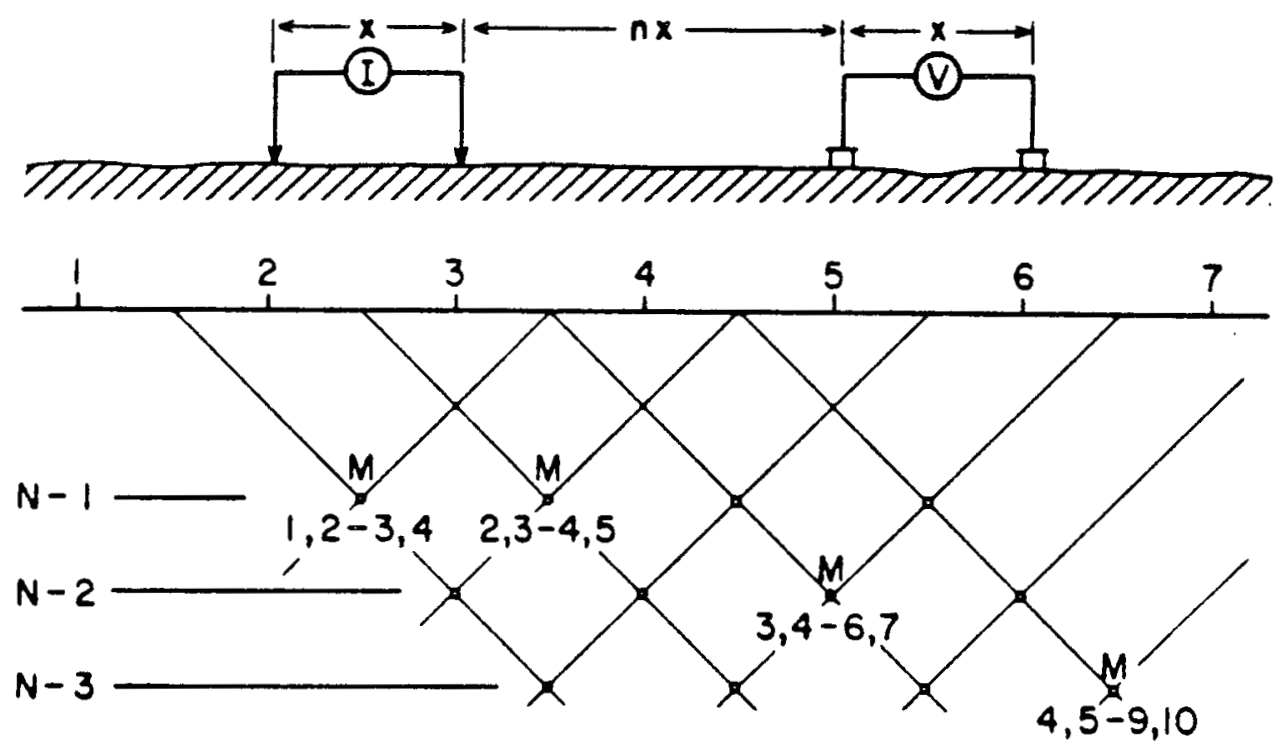

Figure 32. Pseudosection method of plotting dipole-dipole apparent resistivity results. 
Results of all resistivity arrays are presented as plots of apparent resistivity and geometrical spacing. The apparent resistivity is the resistivity of a fictitious homogeneous, isotropic half-space that would produce the same voltage measurement as the actual inhomogeneous earth when the given current and array geometry are used. Results from Wenner and Schlumberger soundings are presented as log-log plots of apparent resistivity versus a or $A B / 2$ spacing, respectively (Figure 30 ). Figure 32 illustrates the method of plotting dipole-dipole apparent resistivity results in so-called pseudosection form. The values are first plotted at depth points determined by the intersection of lines drawn at $45^{\circ}$ angles from the centers of the current and voltage dipoles. The combined results are then contoured to give the final pseudosection. Field results from equatorial soundings are plotted on $\log -\log$ plots identical to Schlumberger or Wenner plots except that the abscissa is the effective spacing, $R$ (Figure 31 ). It can be shown that equatorial sounding curves are identical to Schlumberger results over a layered earth provided $R$ and $A B / 2$ are used as effective spacings, respectively. The convention used in plotting bipole-dipole results is to assign the apparent resistivity to the point $M$ (Figure 31 ) on the map. Final results are contoured yielding a bipole-dipole total field apparent resistivity map. Further details concerning the application of resistivity methods may be found in Jiracek (1982). 
LLANO DE ATRISCO ANOMALY

Introduction

Geothermal exploration in the Albuquerque area concentrated on the western side of the city (Figure 33). This is an area of anticipated growth where the warmest municipal ground-water temperature $\left(32^{\circ} \mathrm{C}\right.$ in 360 $m$ deep West Mesa \#1, Figure 33) was reported by Bjorklund and Maxwell in 1961. The $32^{\circ} \mathrm{C}$ still represents the highest pumped water temperature of a city water well despite inany recent wells, some drilled near the Albuquerque volcanoes (Figure 33 ).

The Albuquerque volcanoes, as described earlier (Figure 4), are a group of fissure-controlled basaltic volcanoes and spatter cones which have been episodically active from about 200,000 to at least 120,000 years before present (Bachman et al., 1975; Kelley and Kudo, 1978; Machette, 1978). They appear to be related to the Nine Mile (County Dump) fault (Figure 33) described by Kelley (1977) and Machette (1978), respectively. The only other mapped faults in the area shown in figure 33 are the unnamed faults on the west side of the figure (Kelley, 1977). Machette (1978) detailed $17 \mathrm{~m}$ of vertical displacement on the County Dump fault (Nine Mile fault) in the past 400,000 years and only ten meters or so of offset was discussed by Kelley (1977) on the faults to the west. 


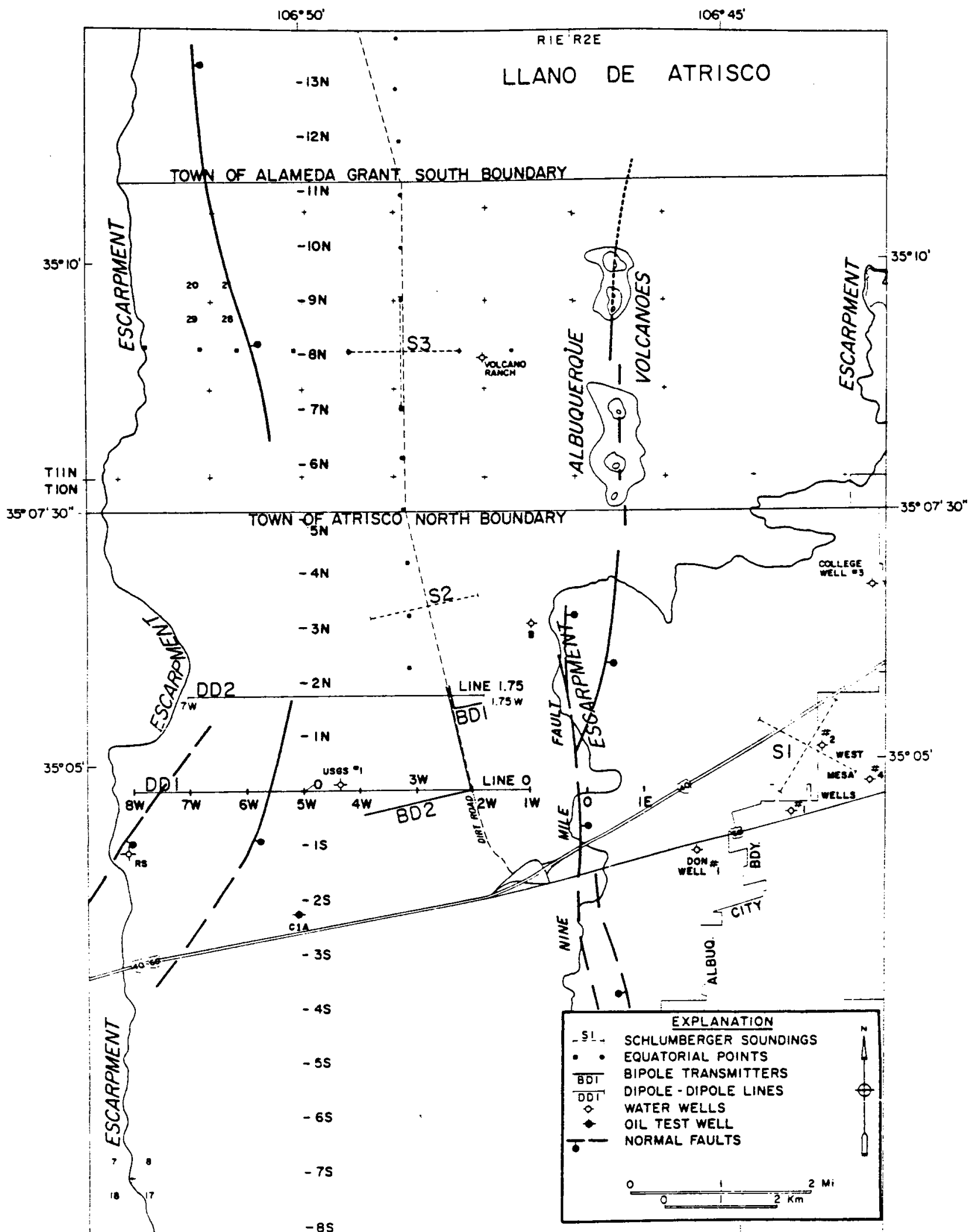

$106^{\circ} 52^{\prime} 30^{\prime \prime}$

$-85$

$106^{\circ} 45^{\circ}$

Figure 33. Base map of Llano de Atrisco area west of Albuquerque. RS and $B$ are radar site and Benavides water wells; C1A is Carpenter \#l Atrisco oil test well. Faults after Kelley (1977). 
The escarpments on the east and west of Figure 33 bound the Ceja Mesa of Kelley (1977) (also called the Llano de Albuquerque) which extends beyond the study area shown in Figure 33 for a total length of $110 \mathrm{~km}$. Parker and Jiracek (1980) have chosen the name Llano de Atrisco for the segment of the mesa encompassed in Figure 33. The northeastern portion of the Llano in Figure 33 is mantled by basaltic lava flows from the Albuquerque volcanoes (Figure 4). Scarps shown on the rest of the map are formed by resistant calichified soil of post-Santa Fe gravel and eolian sands. Underlying beds of youngest Santa Fe sands and gravel are exposed on the erosional scarps. An oil test well (the Carpenter \#1 Atrisco) drilled in 1948 just north of U.S. Highway 66 (Figure 33) in Sec. 28.440, T. $10 \mathrm{~N} .$, R. 1 E. reached $2,027 \mathrm{~m}$ depth before leaving the Santa Fe. Bjorklund and Maxwell (1961) described the bottom $168 \mathrm{~m}$ as having penetrated rocks of "Cretaceous (?) age". The well record on file with the New Mexico Oil Conservation Division is unclear in this regard. As pointed out by Kelley (1977), a projection of the base of exposed Santa $\mathrm{Fe}$ in the Rio Puerco valley only $10 \mathrm{~km}$ to the west of the well intersects the well at depths of about 450 to $600 \mathrm{~m}$ (Figure 2). Consequently, considerable unexposed faulting or increase in eastern dip must exist in the subcrop to the west of the Carpenter \#1 Atrisco well. Kelley (1977) has hypothesized that most of the vertical displacement (over $1,600 \mathrm{~m}$ ) is along the Sand $\mathrm{Hill}$ fault (Figure 2) about $7.5 \mathrm{~km}$ west of the Carpenter \#1 Atrisco well. A deeper $(5,902 \mathrm{~m})$ oil test well has been drilled in 1981 by Shell 0 il Company approximately $2 \mathrm{~km}$ west of the northernmost cone of the Albuquerque volcanoes (Figures 17 and 33). The lithology of the hole, Shell West Mesa Federal No.1-24A (Table 3), has not yet been released. 
Water-table depths in the area of Figure 33 vary from $55 \mathrm{~m}$ at West Mesa \#4 (our measurement) to $285 \mathrm{~m}$ at the former radar site well (Bjorklund and Maxwell, 1961) about $3 \mathrm{~km}$ west-northwest of the Carpenter \#1 Atrisco well (Figure 33). Probably the most significant aspect of the absolute elevation of the ground-water table beneath the area is a pronounced north-south trough 10-15 km wide approximately centered over the Llano de Atriso (Figure 6). The trough described by Bjorklund and Maxwell (1961) is about $10 \mathrm{~m}$ lower than the Rio Grande $10 \mathrm{~km}$ to the east and perhaps $35 \mathrm{~m}$ below the water level at the radar site well. These values are based on very few data (water wells); however, a more recent compilation by the U. S. Geological survey (D. Wilkins, personal communication, 1981) confirms a considerable hydraulic gradient on the west side of Figure 33 of approximately $10 \mathrm{~m} / \mathrm{km}$. This implies significant eastward water movement on the west side of the Llano de Atrisco.

Electrical resistivity investigations in the Albuquerque area consisted first in 1979 of Schlumberger and combined Schlumbergerequatorial soundings at three locations, S1, S2, and S3 (Figure 33). The soundings were followed in the same year by bipole-dipole mapping from two orthogonal bipole transmitter pairs BD1 and BD2, Figure 33. Two dipole-dipole lines DD1 and DD2 (Figure 33) were measured in 1980. Surface magnetic profiles totaling $171 \mathrm{~km}$ were occupied in 1980. These followed initial measurements of less than $10 \mathrm{~km}$ length made earlier, in 1979.

Shallow $(<30 \mathrm{~m})$ temperature gradient measurements (described earlier) were made on the Llano de Atrisco during 1979-80. Some 
anomalously high values $\left(>100^{\circ} \mathrm{C} / \mathrm{km}\right)$ measured in the shallow drillholes in 1980 exposed the need for deep gradient values, particularly below the water table. One such measurement has been made in a $364 \mathrm{~m}$ deep borehole. Data from this U. S. Geological Survey water monitor well \#1 (Figure 33), drilled in the summer of 1981 by the Survey and the City of Albuquerque with our cooperation, are plotted in Figure 23.

\section{Temperature Gradient Survey}

Following the discovery of high shallow temperature gradients $\left(>75^{\circ} \mathrm{C} / \mathrm{km}\right.$ in the upper $\left.25 \mathrm{~m}\right)$ on the Llano de Atrisco in 1979 by eight drillholes, 53 additional holes were drilled in 1979-80 in the area. All but one of the holes were positioned on a grid of $1 \mathrm{~km}$ spaced lines and stations, e.g., Lines $0,1 N, 2 N, \ldots, 1 S, 2 S, \ldots$; Stations $0,1 W$, $2 W, 3 W, \ldots$ (Figures 33 and 34 ). Most wells were drilled to $25 \mathrm{~m}$ to penetrate below the effect of the annual temperature wave $(<10-15 \mathrm{~m})$. Initial results from the holes were presented by Parker and Jiracek (1980); Figure 34 contains contours of these shallow thermal gradient values after reoccupation of most sites and least squares fitting of the temperature curves (Jiracek et al., 1982). Most significant (Figure 34) is the high gradient anomaly, reaching $140^{\circ} \mathrm{C} / \mathrm{km}$, centered over Line 0 , Station 5W. Figure 35 shows examples of the measured shallow, temperature gradient data from multiple reoccupations of Stations $5 \mathrm{~W}$ and $6 \mathrm{~W}$ on line 0 . Measured temperature gradient data from all shallow gradient holes on the Llano de Atrisco are reproduced in Appendix A. Variations in temperature gradients in the upper $10 \mathrm{~m}$ or so (Figure 35 ; Appendix A) are due to the annual wave caused by seasonal surface 


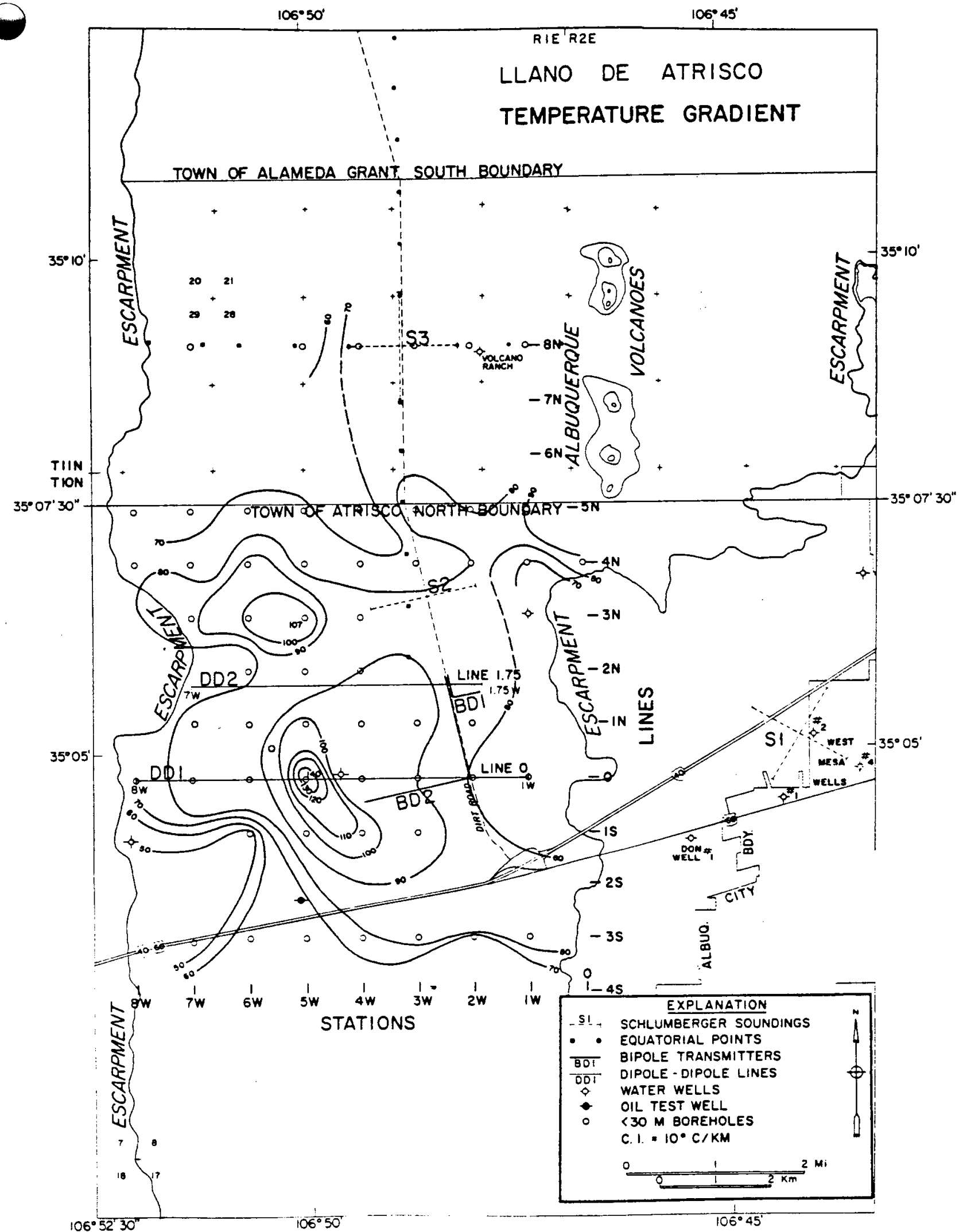

Figure 34. Shallow temperature gradient mag of Llano de Atrisco in Al buquerque area. Contours in $\mathrm{C} / \mathrm{km}$. 

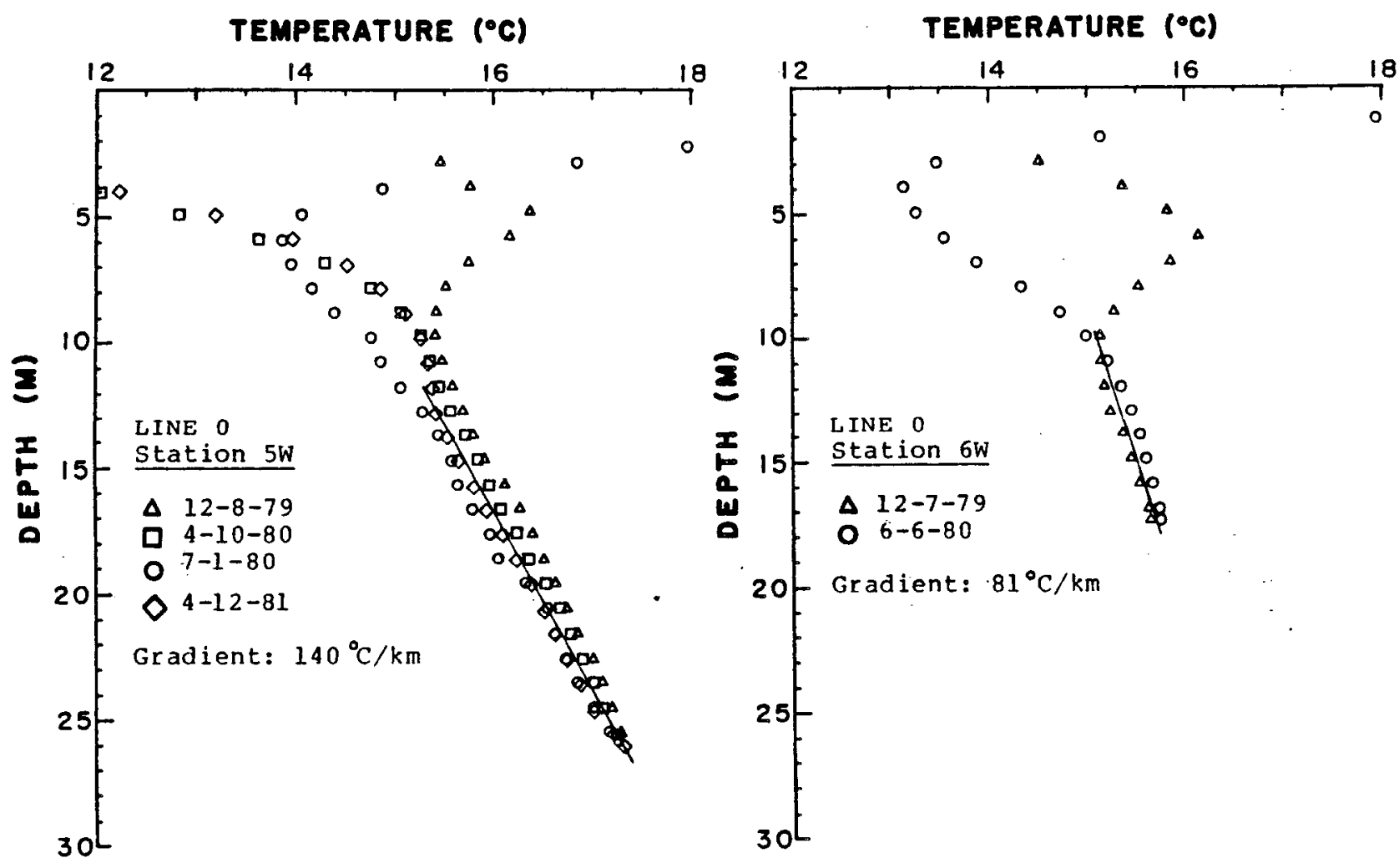

Figure 35. Shallow temperatures measured in test holes located on Line 0 , Stations $5 \mathrm{~W}$ and $6 \mathrm{~W}$ of Llano de Atrisco. 
temperature variations. Both the $140^{\circ} \mathrm{C} / \mathrm{km}$ anomaly and a lesser one of $107^{\circ} \mathrm{C} / \mathrm{km}$ to the north have small area (Figure 34 ) indicating shallow sources of ,limited extent.

\section{Resistivity Measurements}

Schlumberger soundings (Figure 30 ) were made on the Llano de Atrisco at two sites, S2 and S3 (Figure 33), to evaluate the ability of resistivity to detect and characterize deep ground-water aquifers. The sites are near the Benavides and Volcano Ranch stock wells where the water-table depths are precisely known. Our downhole measurements in the abandoned Benavides well, less than $2 \mathrm{~km}$ east of site $\mathrm{S2}$, probed the water table at a depth of $271 \mathrm{~m}$. This corresponds with a resistivity interface at $299 \mathrm{~m}$ between 33 and 16 ohm-m layers interpreted using the Zohdy (1973) inversion method on the observed S2 Schlumberger results (Figure 36). Such an approximate magnitude of resistivity change has been noted to occur (Jiracek, 1982) at the water table on geophysical logs recorded in the municipal West Mesa well field (Figure 33). The change in interpreted resistivity from 16 to $8 \mathrm{ohm}-\mathrm{m}$ at $609 \mathrm{~m}$ depth at S2 is due to increased water salinity as a function of depth.

A $16 \mathrm{ohm}-\mathrm{m}$ layer is obtained from inversion of the $53-90^{\circ}$ results at a depth of $271 \mathrm{~m}$ (Figure 37) near Volcano Ranch. This agrees well with the water-table depth of $266 \mathrm{~m}$ reported by Bjorklund and Maxwell (1961) at the ranch. The Schlumberger soundings at $\$ 3$ were extended to effective spacings of over $5 \mathrm{~km}$ using equatorial soundings (Figure 31 ). The zone, from 271 to $4,303 \mathrm{~m}$ depth, is interpreted as nearly the entire water-saturated sedimentary section above the Precambrian basement 


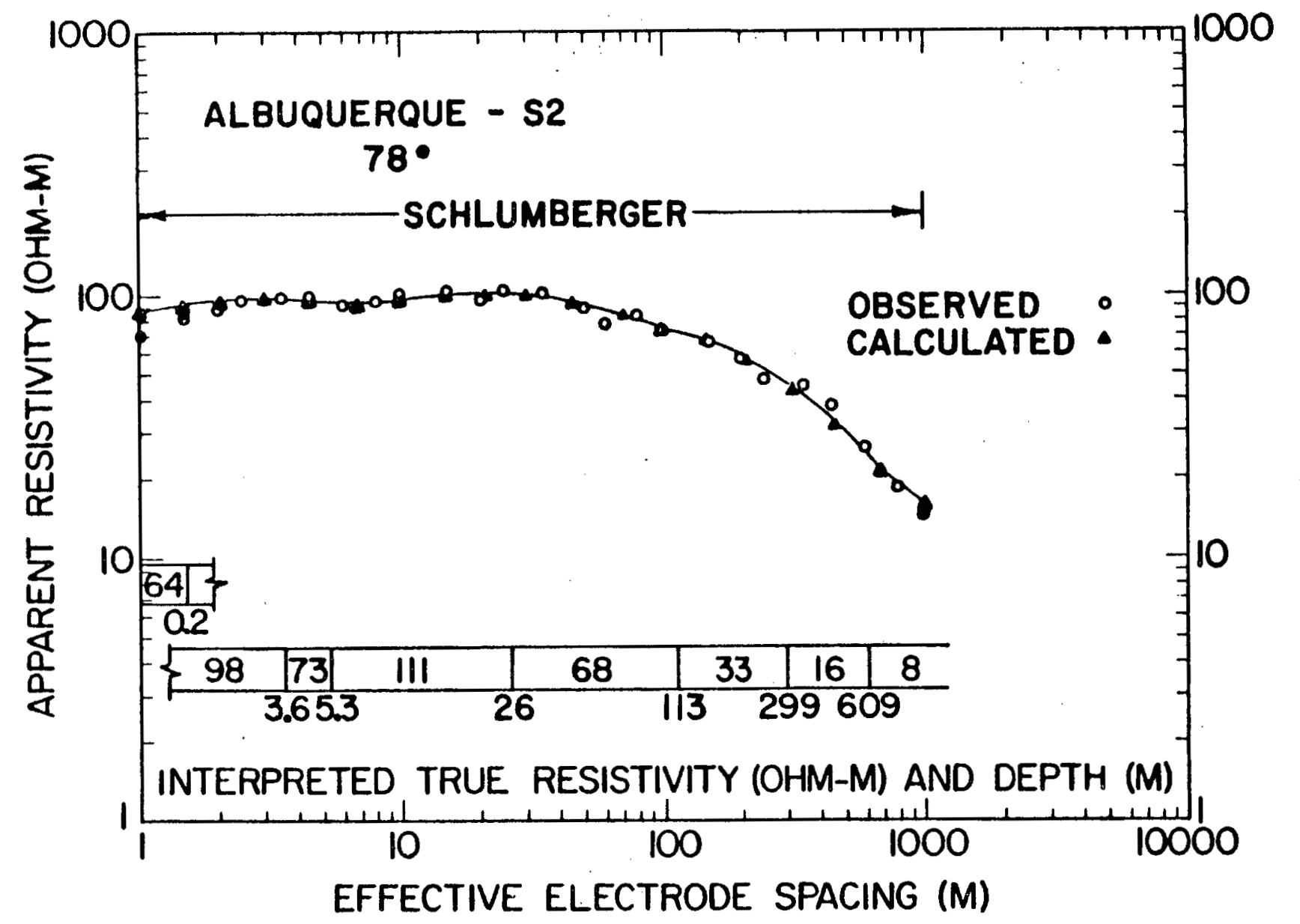

Figure 36. Observed and calculated Schlumberger sounding $S 2-78^{\circ}$ on Llano de Atrisco in Albuquerque area and interpreted eight-layer resistivity model. 


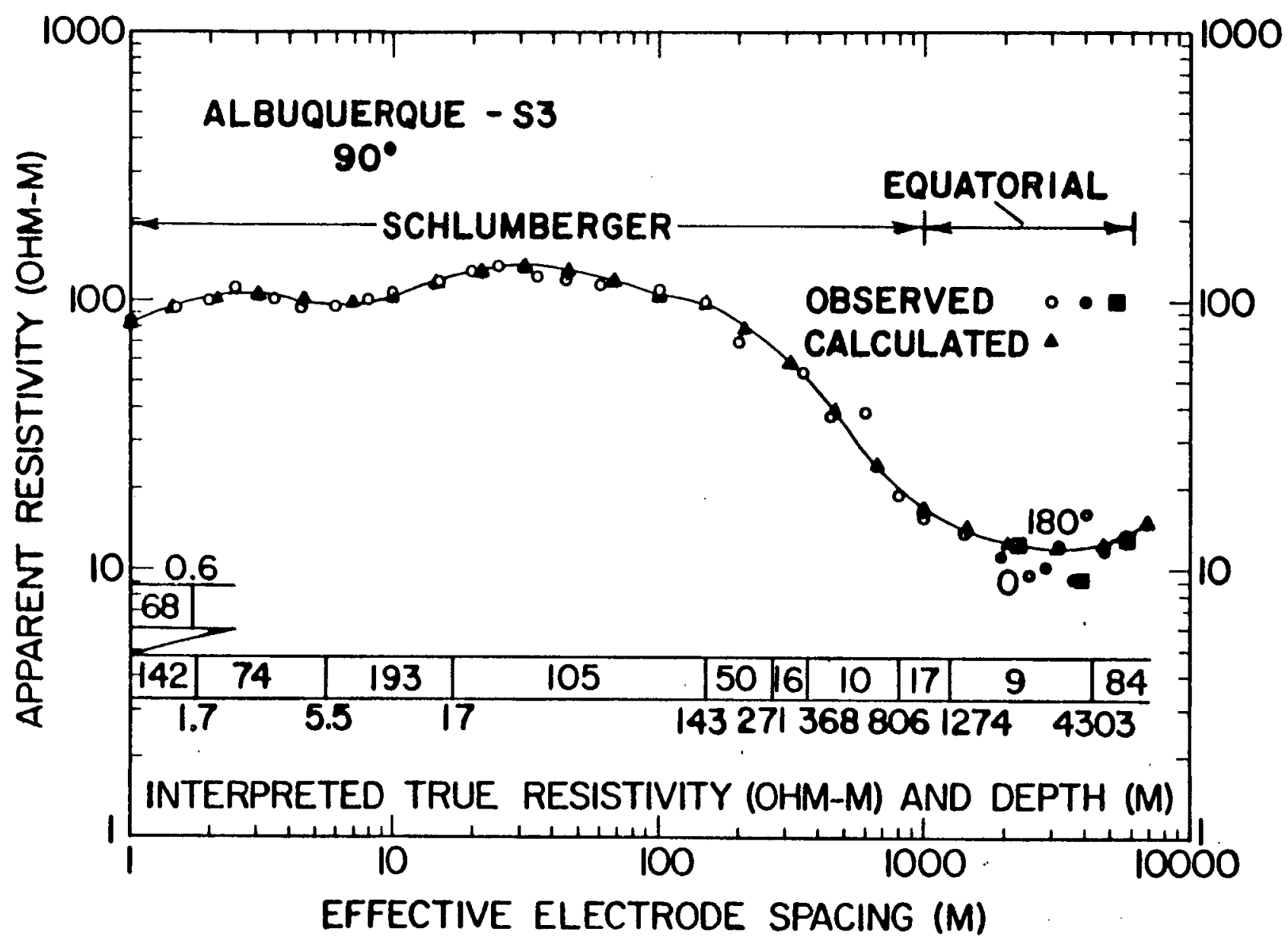

Figure 37. Observed and calculated Schlumberger sounding $S 3-90^{\circ}$ on Llano de Atrisco in Albuquerque area and interpreted eleven-layer resistivity model. 
(Table 1). The Precambrian interface is estimated to be at a depth of about $4,800 \mathrm{~m}$ here from gravity modeling (Birch, 1980; 1982). However, the nearby Shell West Mesa Federal oil test well (Figure 17) reportedly bottomed at $5,902 \mathrm{~m}$ in Morrison Formation of Mesozoic age (K. Hatton, personal communication, 1982). Our data are not sufficiently precise to resolve the existence of the fresher water zone modeled from 806 to $1,274 \mathrm{~m}$ depth at S3 (Figure 37). However, resistivity soundings shown in Figures 36 and 37 clearly detect and correctly measure the depth to the water table on the Llano de Atrisco.

For reconnaissance detection of lateral resistivity variations in the Llano de Atrisco test area we employed two bipole (Figure 31) transmitter pairs (BD1 and BD2) as shown in Figure 33. Results from the $\sim N S 500 \mathrm{~m}$ bipole of BD1 are contoured in values of total field apparent resistivity in Figure 38. The results were obtained from 75 roving dipole stations surrounding the bipoles.

The near-symmetry of the contours around the bipole sources indicates comparative lateral homogeneity in the area sensed by the bipoles. An indication of the agreement or disagreement between BD1 bipole-dipole mapping and nearby $S 2$ and $\$ 3$ soundings is facilitated by the theoretical bipole-dipole results (Zohdy and Stanley, 1974) presented in Figure 39. The total field apparent resistivity contours are those appropriate to a $500 \mathrm{~m}$ bipole source over a layered earth indicated by the S2 Schlumberger curve extended using the $53-90^{\circ}$ equatorial results (Figures 36 and 37 ). Contours in Figure 39 illustrate the characteristic peanut-shape of such maps over horizontally layered media as discussed by Zohdy (1978). The general 


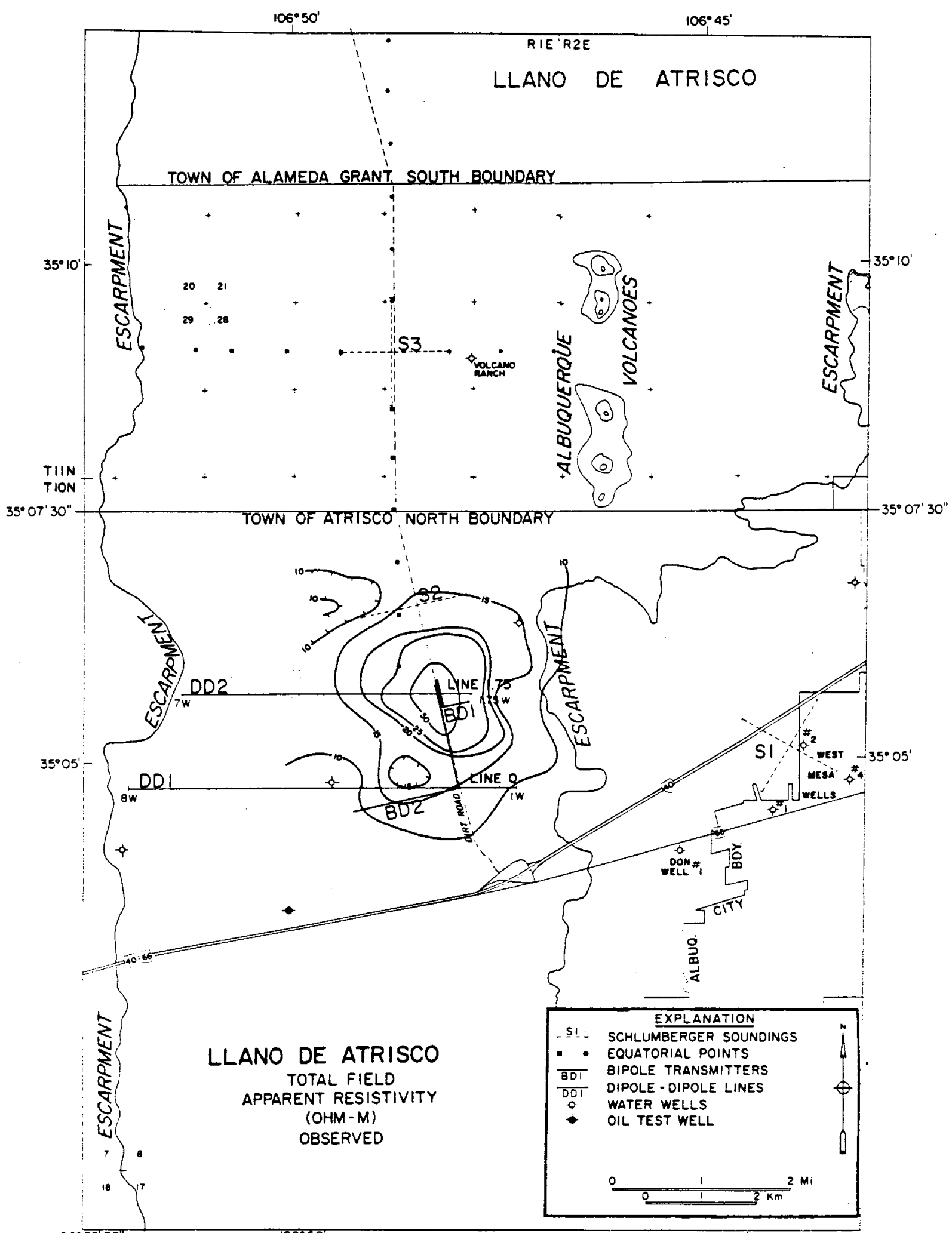

$106^{\circ} 52^{\prime} 30^{\prime \prime}$

$106^{\circ} \cdot 45^{\prime}$

Figure 38. Observed total field apparent resistivity map derived from $\sim$ NS BDI transmitter on Llano de Atrisco in Albuquerque area. 


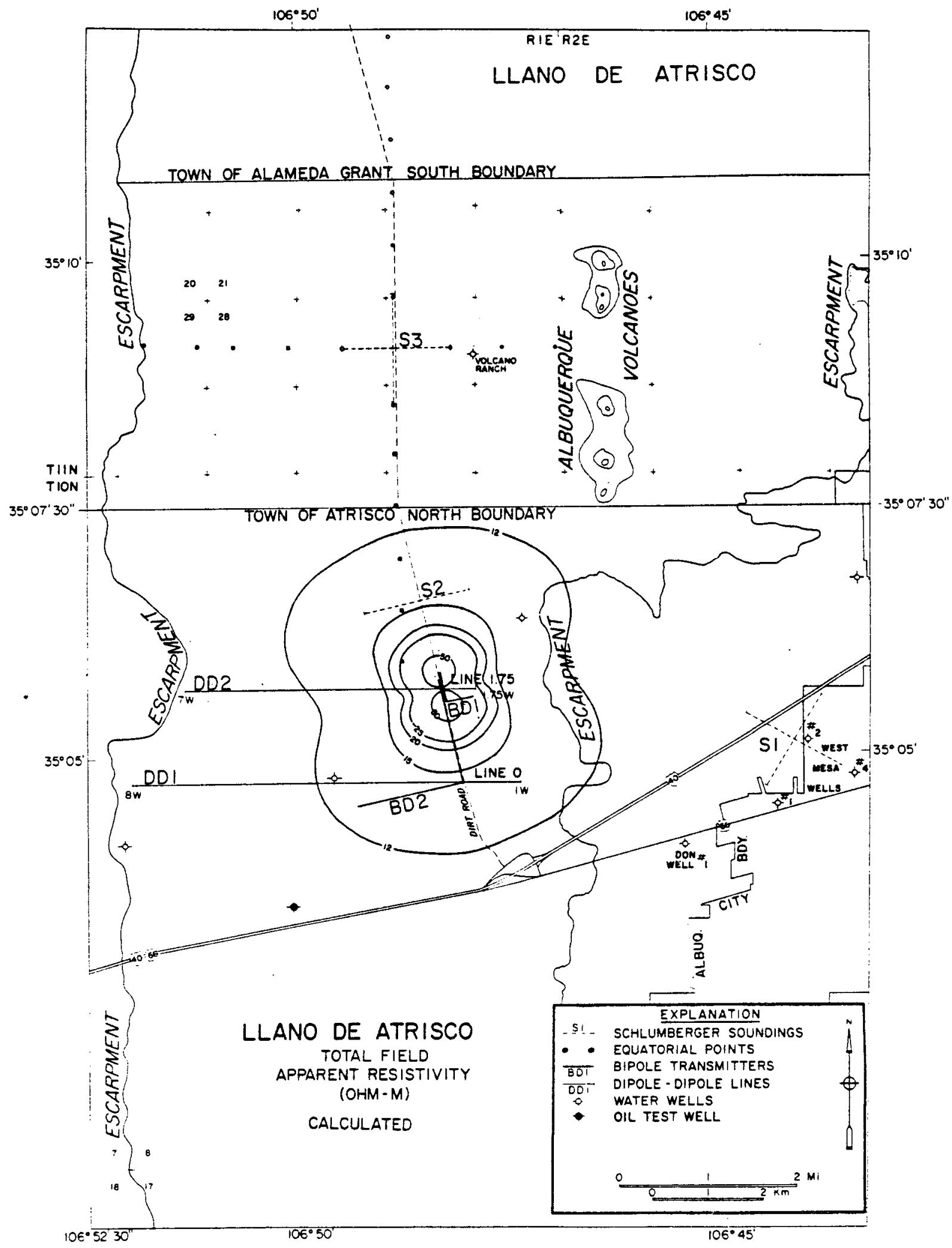

Figure 39. Calculated BDI total field apparent resistivity map derived from layered earth estimated from Schlumberger $\mathrm{S} 2$ and equatorial $53-90^{\circ}$ results. 
shape and area enclosed by the contours, e.g., $15 \mathrm{ohm}-\mathrm{m}$ in Figures 38 and 39 illustrates a compatibility with the S2 and S3 layered sections (Figures 36 and 37 ).

The desire to extend the resistivity mapping over a larger area than obtainable from BDl dictated using larger bipole sources; the observed results from the $2 \mathrm{~km} \sim N S$ transmitter of BD2 are shown in Figure 40. Again about 75 receiver stations were occupied but at spacings averaging nearly $1 \mathrm{~km}$ apart compared to the approximately $0.5 \mathrm{~km}$ separations used with BD1. The area covered by the mapping results in Figure 40 is about $85 \mathrm{~km}^{2}$. Figure 41 is the theoretical bipole-dipole map constructed in the same fashion as in Figure 39 but now using a $2 \mathrm{~km}$ bipole current source. A very striking lateral resistivity anomaly is revealed by the comparison of Figures 40 and 41 . The resistivity ridge clearly manifested on the west side of Figure 40 is defined by several roving dipole points and maps a significant subsurface feature. Understanding this feature and its relation to the geothermal hydrology of the Llano de Atrisco requires the integration of several geophysical measurements including additional, detailed resistivity measurements.

The uncovering of the near-coincidence of the resistivity ridge in Figure 40 and the maximum subsurface temperature gradient on the Llano de Atrisco (Figure 34) led us to a more detailed resistivity survey. This dipole-dipole survey (Figure 30) was directed at detecting lateral resistivity variations which might explain the association of the resistivity high and the shallow thermal anomaly.

Two dipole-dipole lines were traversed across the Llano de Atrisco during the summer of 1980. One line (DD1 in Figure 33) was run across the temperature gradient peak seen on survey Line 0 (Figure 34 ). The 


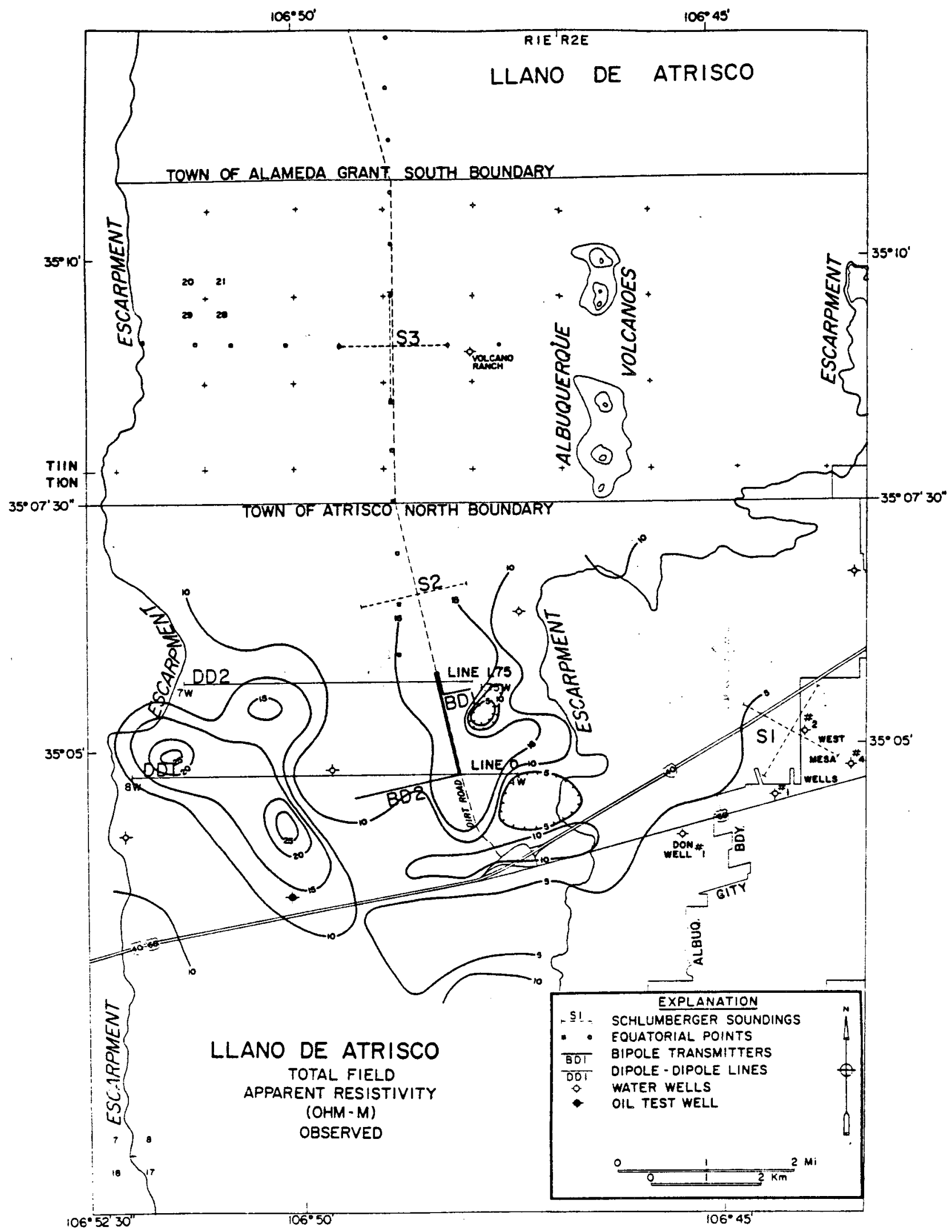

Figure 40. Observed total field apparent resistivity map derived from NS BD2 transmitter on Llano de Atrisco in Albuquerque area. 


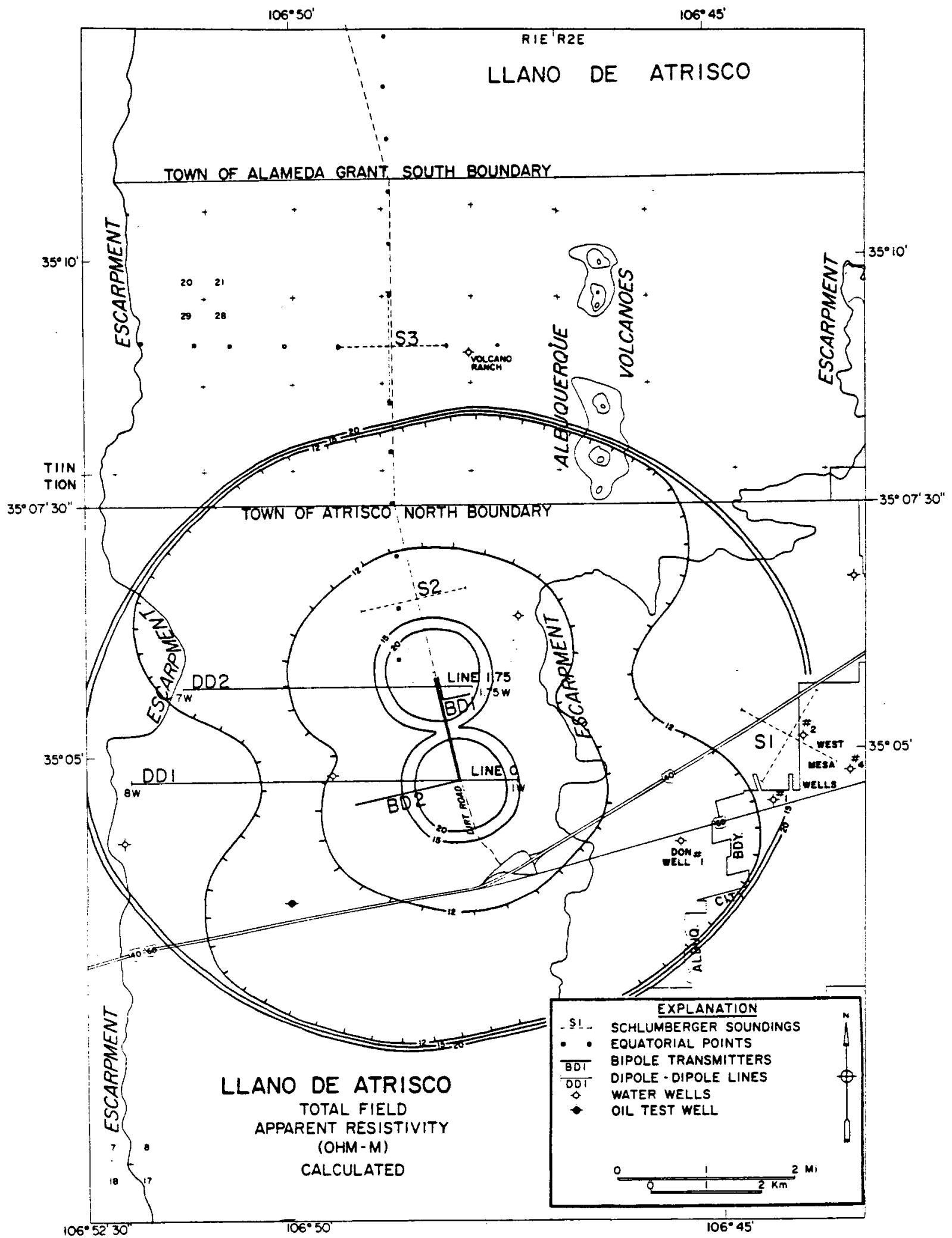

Figure 41. Calculated BD2 total field apparent resistivity map derived from layered earth estimated from Schlumberger S2 and equatorial $53-90^{\circ}$ results. 
traverse was $8 \mathrm{~km}$ long, used dipoles of $250 \mathrm{~m}$, and dipole expansions were increased from $n=1$ to 7 . Another shorter line, $5 \mathrm{~km}$ 1 ong DD2, was positioned $1.75 \mathrm{~km}$ north (Figure 33 ) to cross a magnetic anomaly discovered during the initial field tests (Parker and Jiracek, 1980).

Figure 42 shows the observed DD1 dipole-dipole results in pseudosection form (Figure 32) and the calculated model results using the finite difference routine developed by Dey (1976). Although the observed and calculated results show a reasonably high degree of match, one is cautioned regarding the nonuniqueness of the corresponding resistivity model. In the model, the 80 and $20 \mathrm{ohm}-\mathrm{m}$ layers above $500 \mathrm{~m}$ represent the surficial layers and upper water-saturated zones, respectively, seen in Schlumberger soundings S2 and S3 (Figures 36 and 37). The $8 \mathrm{ohm}-\mathrm{m}$ zone (Figure 42) corresponds to the more conductive, saline waters probed by the soundings. The most significant feature of the $\mathrm{DD} 1$ results is a highly resistive zone detected and modeled between surface locations $5 W$ and $7 W$ (Figure 42 ). The modeling suggests a resistive $(60 \mathrm{ohm}-\mathrm{m})$ projection into the shallow sequence and a possible draping of the $8 \mathrm{ohm}-\mathrm{m}$ zone over it. Modeling of the DD2 results in Figure 43 produced a similar feature which is displaced approximately one kilometer to the west.

Resistive electrical basement rock, such as the $60 \mathrm{ohm}-\mathrm{m}$ blocks modeled in Figures 42 and 43, has not been detected by our measurements el sewhere on the Llano de Atrisco at such shallow depths. As discussed earlier, resistive basement ( 84 ohm-m) modeled at S3 (Figure 37) at about 4,300 $\mathrm{m}$ depth possibly represents Precambrian rock in agreement with recent gravity modeling. The resistive (60 ohm-m) bedrock modeled on the dipole-dipole lines in Figures 42 and 43 is not expected to be 

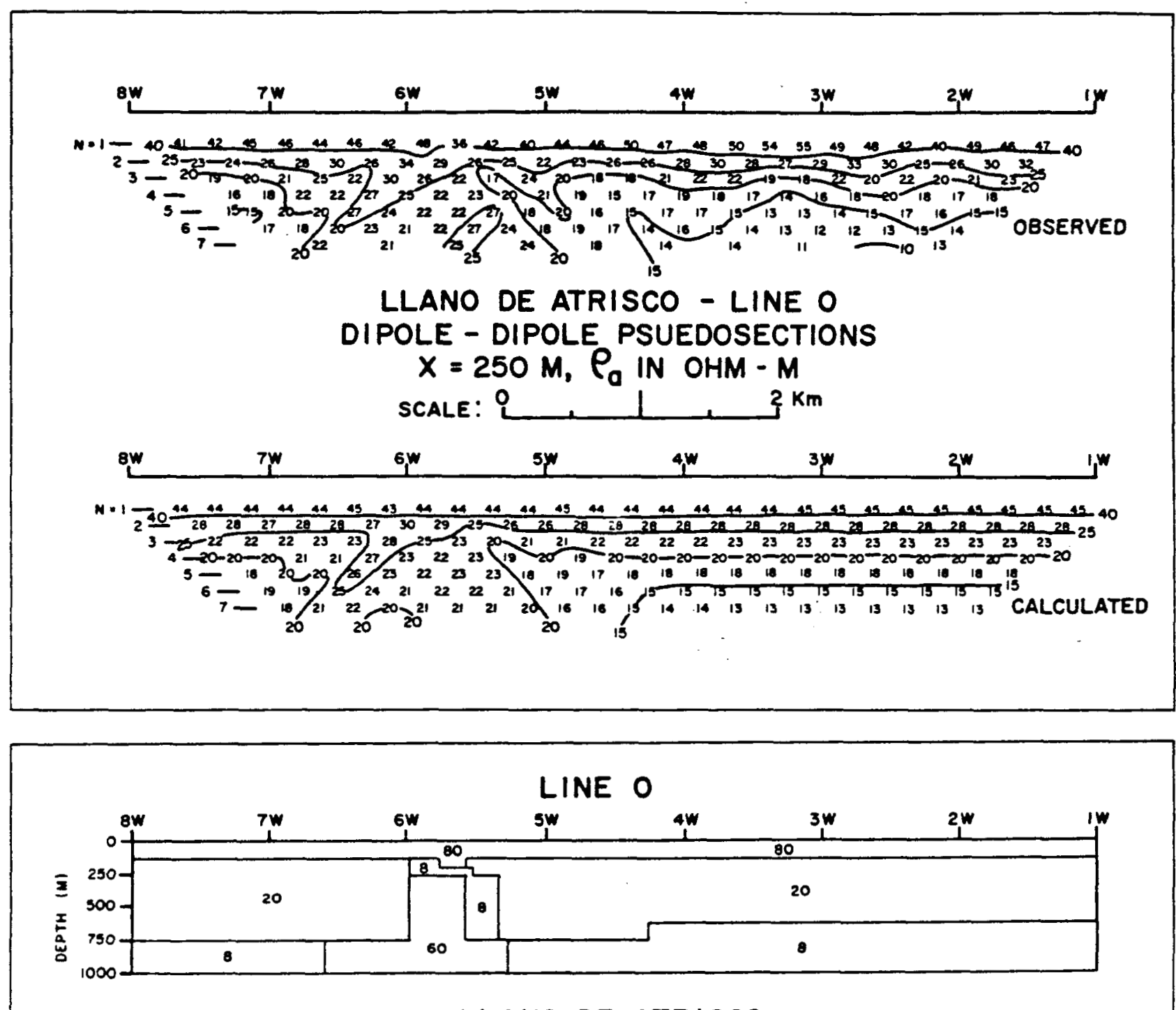

\section{LLANO DE ATRISCO \\ CALCULATED RESISTIVITY MODEL \\ RESISTIVITY IN OHM - M}

SCALE: O $2 \mathrm{Km}$

Figure 42. Observed and calculated dipole-dipole 001 pseudosections and calculated two-dimensional resistivity model along Line 0 of Llano de Atrisco in Albuquerque area. 


\section{LINE 1.75}

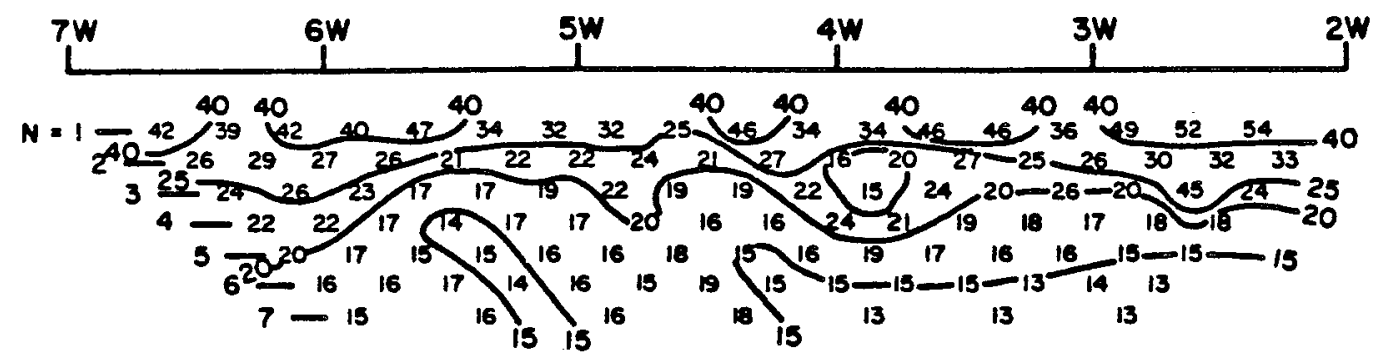

\section{LLANO DE ATRISCO}

DIPOLE - DIPOLE PSUEDOSECTIONS

\section{$X=250 \mathrm{M}$, PO IN OHM - M}

SCALE:
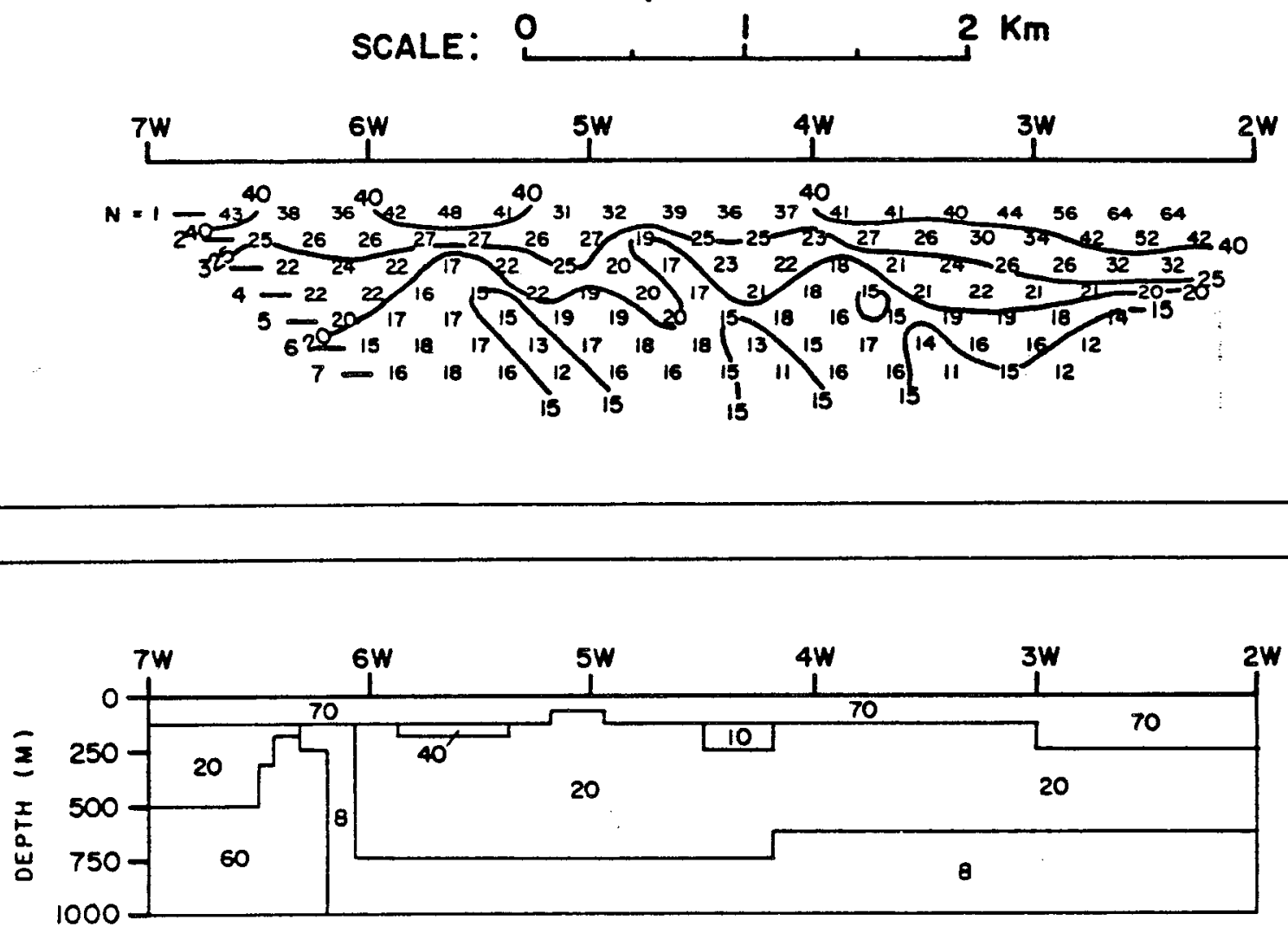

LLANO DE ATRISCO - LINE 1.75

CALCULATED RESISTIVITY MODEL

RESISTIVITY IN OHM - M

SCALE: $2 \mathrm{Km}$

Figure 43. Observed and calculated dipole-dipole DD2 pseudosections and calculated two-dimensional resistivity model along Line $1.75 \mathrm{~N}$ of Llano de Atrisco in Albuquerque area. 
Precambrian basement but is more likely impermeable Mesozoic strata as described later.

\section{Magnetic Survey}

A total field magnetic map of the Llano de Atrisco is presented in Figure 44. An areal coverage of $175 \mathrm{~km}^{2}$ was obtained using Geometrics G-806 and G-816 proton precession magnetometers. Magnetic measurements were made $100 \mathrm{~m}$ apart on the survey lines indicated in Figure 33. Shorter east-west survey lines and some north-south lines were positioned closer than $1 \mathrm{~km}$ when deemed necessary for detail. Readings over the surface lava flows of the Albuquerque volcanoes were too erratic for meaningful results.

The two temperature gradient highs (Figure 34 ) and nearby magnetic anomalies (Figure 44) disclosed by the initial 1979 ground survey were thought to have a causative relationship (Parker and Jiracek, 1980). Though this may be the case, the very extensive magnetic survey of the Llano during 1980 (Figure 44) has clearly shown that the resistive anomaly in Figures 40,42 , and 43 is nonmagnetic. Furthermore, the dipole-dipole results of DD2 (Figure 43) which cross the highest magnetic anomaly in the entire survey area between Stations $3 W$ and $4 \mathrm{~W}$ on Line $1.75 \mathrm{~N}$ do not measure a corresponding large resistivity high. The highest dipole-dipole resistivity at depth is measured between Stations $5 \mathrm{~W}$ and $6 \mathrm{~W}$ on DD1 (Figure 42) where the magnetic field is relatively flat (Figure 44).

Three-dimensional modeling of the magnetic patterns in Figure 44 suggests sill-like bodies at approximately $300 \mathrm{~m}$ depth. This estimate 


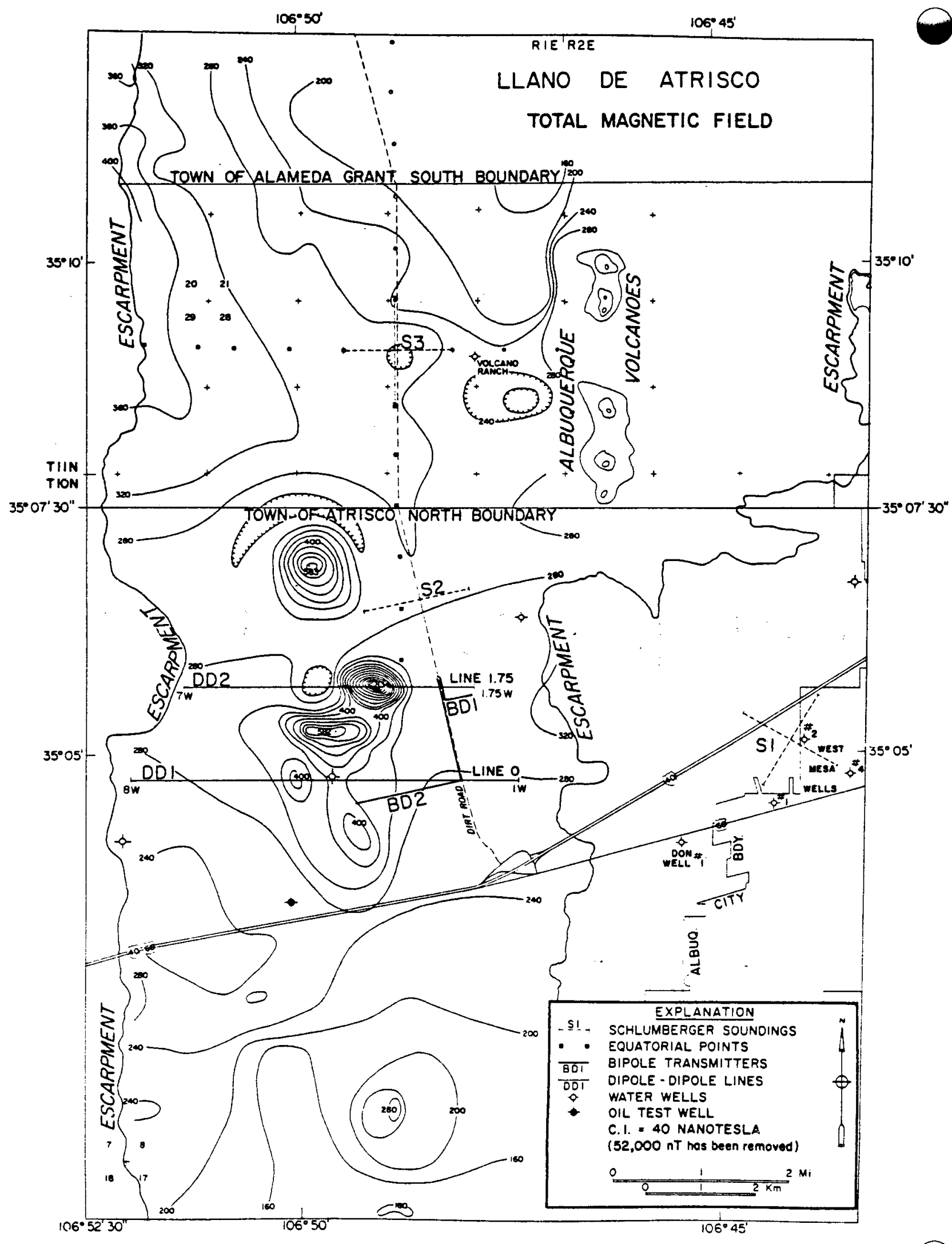

Figure 44. Total magnetic field map of Llano de Atrisco in Albuquerque area. Contours in nanoteslas. 
is very close to where a basaltic layer was intersected at the bottom (364 $\mathrm{m}$ ) of the recent U. S. Geological Survey water monitor well (G. Hammock, personal communication, 1981) drilled at Line 0, Station 4.3W (Figure 33). Modeling was accomplished using a computer program written following the formulation of Bhattacharyya (1964). The program calculates the total field magnetic anomaly over a prism-shaped body with vertical sides and flat top and bottom (Figure 45). Any angle of magnetic polarization vector can be chosen relative to the geomagnetic field direction, thus allowing for both remanent and induced magnetism.

The relative contributions and directions of remanent and induced magnetism are unknown in the causative bodies producing the anomalies in Figure 44. An igneous body that cooled through the Curie temperature in the last 700,000 years would be expected to have normal remanent polarization. Our modeling has assumed this. More precisely, the total polarization direction has been assumed to be in the direction of thecurrent geomagnetic field in the area, i.e., inclination (I) of $63^{\circ}$ and declination (D) of $12.5^{\circ} \mathrm{E}$ (Figure 45 ).

The choice of the susceptibility contrast $(K)$ of the anomalous magnetic bodies and the surrounding sedimentary sequence has been made after several considerations. The method of Vacquier et al. (1951) gave estimates of $K=2,000 \times 10^{-6}$ and $K=10,000 \times 10^{-6} \mathrm{cgs}$ for the anomalies intersected by survey 1 ines $4 \mathrm{~N}$ and $1.75 \mathrm{~N}$, respectively (Figure 44). However, drillhole cuttings from lava flows of the Albuquerque volcanoes produced susceptibility values of less than $700 \times 10^{-6} \mathrm{cgs}$. Our laboratory measurements do not reflect any remanent component to the magnetic polarization so the difference between the laboratory measurements and the calculations using the field anomalies may 


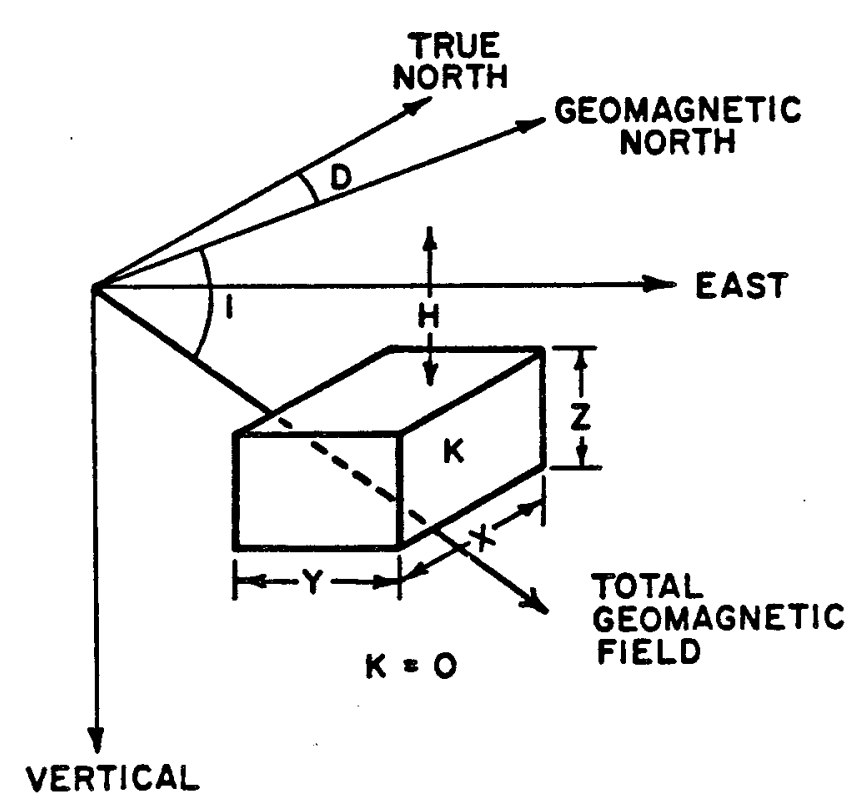

\section{MAGNETIC PRISM MODEL}

Figure 45. Magnetic prism model.

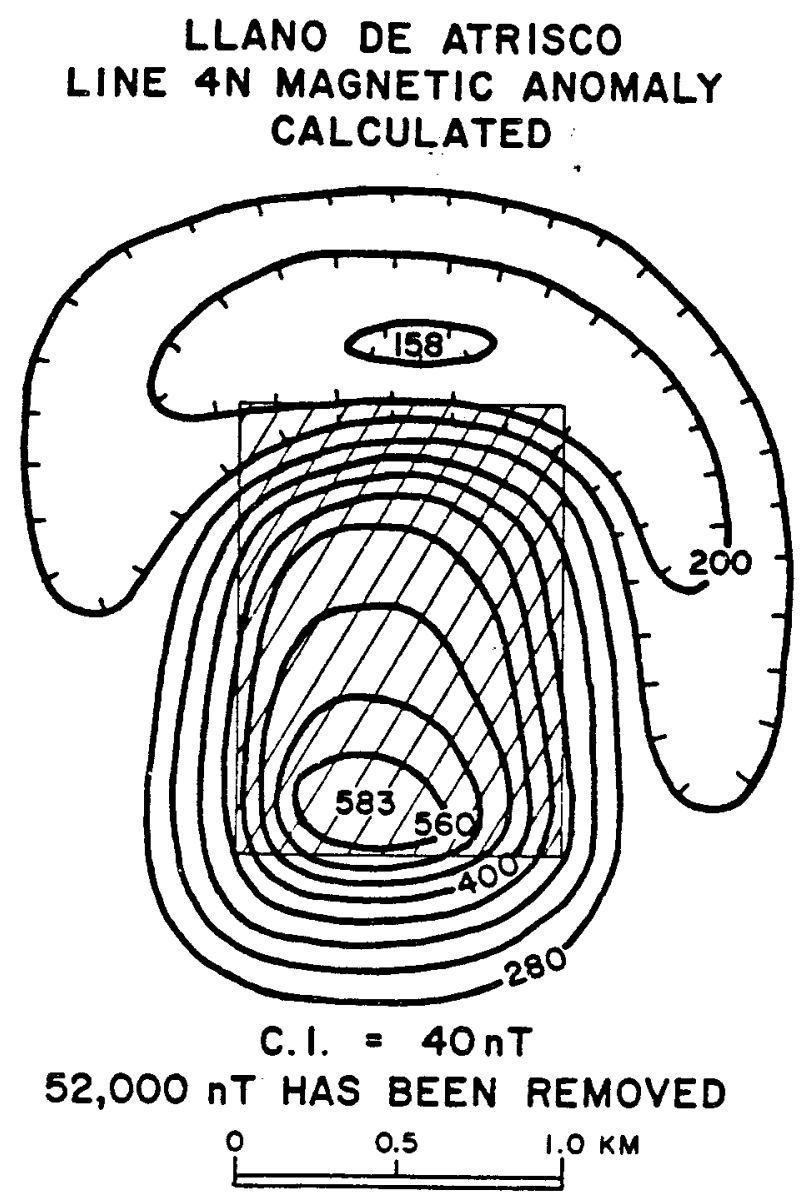

Figure 46. Calculated magnetic anomaly crossed on Line $4 \mathrm{~N}$ of Llano de Atrisco in Albuquerque area. Hatchured area is plan view of prism body. 
approximate the degree of remanence. Consequently, the ratio of remanent to induced magnetization may be a minimum of two and perhaps over thirteen. Basalt samples from near Santa Fe, New Mexico were measured to have ratios between 3.3 and 14.2 (Spiegel and Baldwin, 1963). The highest effective susceptibility measured in these samples was reported to be $9,600 \times 10^{-6} \mathrm{cgs}$. This value has been assumed in our modeling as an effective susceptibility, i.e., one that includes combined remanent and induced components in polarization.

An example of the magnetic modeling appears in Figure 46 where the isolated anomaly centered on Line $4 N$ (Figures 33 and 44 ) has been closely matched. The prism body modeled in this case is $1.4 \mathrm{~km}$ in north-south extent and $1.0 \mathrm{~km}$ east-west. It is at a depth of $275 \mathrm{~m}$ and is $87.5 \mathrm{~m}$ thick. This is certainly not a unique model; however, the results are consistent with a body that is thin with its top very near the water-table depth. The sharper anomaly on Line $1.75 \mathrm{~N}$ (Figures 33 and 44) is likely shallower, possibly nearer to $200 \mathrm{~m}$ depth.

There are at least ten volcanic layers listed in the $2,027 \mathrm{~m}$ well record from the nearby Carpenter \#1 Atrisco (Figure 33); the thickest layer, however, is only $27 \mathrm{~m}$. Resistivity logs of this wildcat oil test record resistivities in excess of $1,000 \mathrm{ohm}-\mathrm{m}$ in some volcanic layers and surface resistivity measurements on flows of the Albuquerque volcanoes by Brandwein (1974) yielded values of 2,850 ohm-m. Such highly resistive layers at $\leqslant 300 \mathrm{~m}$ depth would be easily detected by surface resistivity measurements unless they are thin $(<50 \mathrm{~m})$ or contain appreciable interconnected water. All of the above considerations lead us to the conclusion that the resistive ridge detected by bipole-dipole mapping and dipole-dipole sounding-profiling is not due to subsurface volcanics. 


\section{Conclusions}

A possible explanation of the resistive ridge and its relation to the thermal anomaly can be gleaned from a consideration of the gravity patterns (Birch, 1980; 1982) over the test area (Figure 47 ). It is quite obvious from the contours on the west side of the map that a residual gravity anomaly is present. Removal of a reasonable regional gradient yields an approximately $6 \mathrm{mGal}$ north-northwest trending residual centered roughly over Station 5 W, Line 0 . Birch $(1980,1982)$ computer modeled an east-west gravity profile passing directly through the Carpenter \#1 Atrisco well (Figure 12); He modeled $2.4 \mathrm{~g} / \mathrm{cm}^{3}$ (Mesozoic) strata to be upfaulted to within $300 \mathrm{~m}$ of the surface only $2.5 \mathrm{~km}$ west of the well. This is not nearly as far west (Figure 2) as suggested by Kelley (1977). A closed residual gravity anomaly produced by removing the regional trend in Figure 47 would suggest an additional ridge or knob on the upthrown block identified by Birch. Thus, the resistivity ridge in conjunction with the residual gravity anomaly is consistent with a shallow horst-like structure on the west side of the Llano de Atrisco. Additional detailed gravity measurements would better outline the structure. It is interesting to note that the driller's log of the water. well at the radar site (Bjorklund and Maxwell, 1961) terminates with the last entry from 418 to $422 \mathrm{~m}$ described as "rock, hard; cut bit".

It is enlightening to compare the various geophysical measurements over the maximum thermal gradient high on the Llano de Atrisco. These are shown in Figure 48 for the therma? gradient, dipole-dipole 


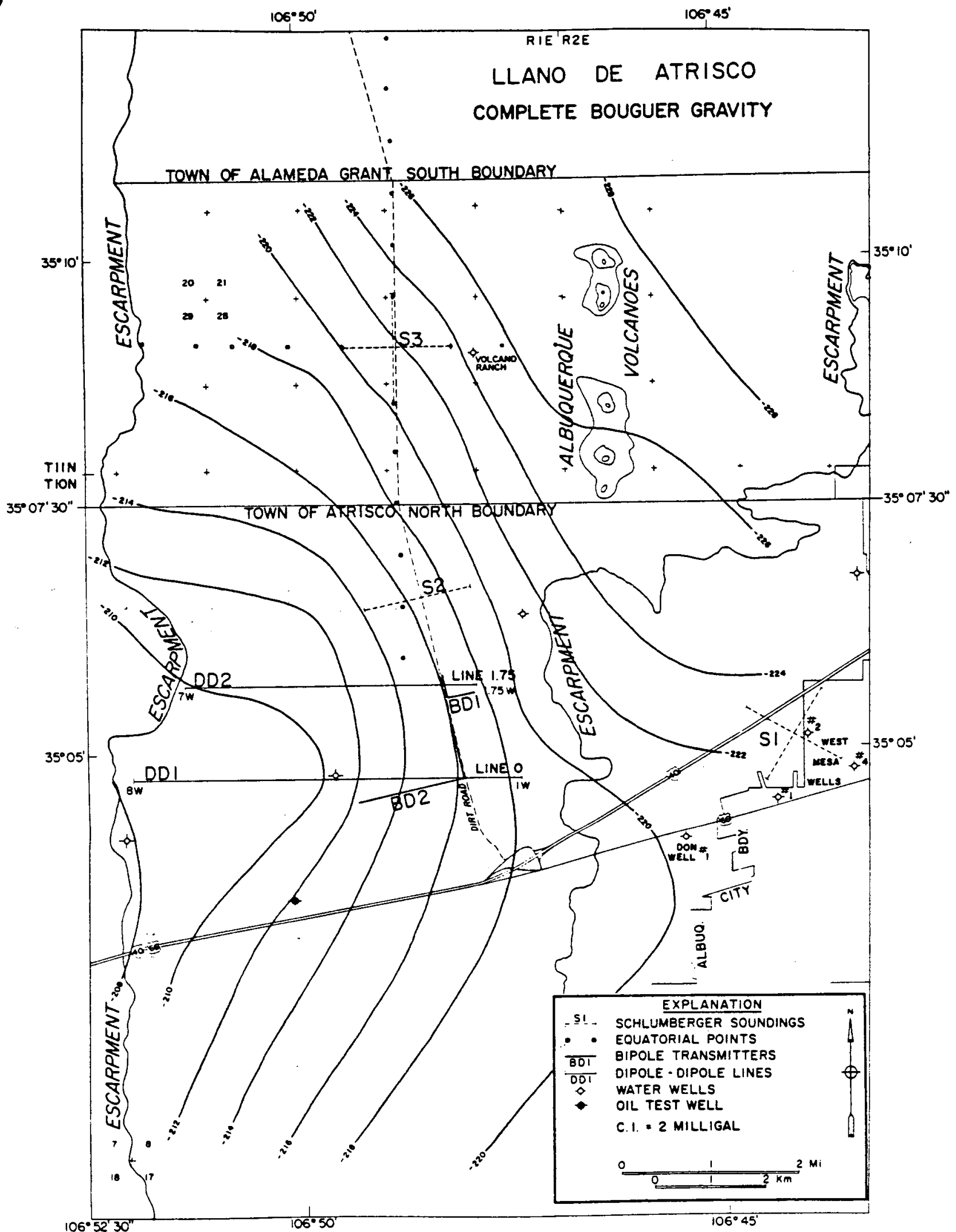

Figure 47. Complete Bouguer gravity map of Llano de Atrisco in Albuquerque area. Contours in milligals (after Birch, 1980; 1982 ). 

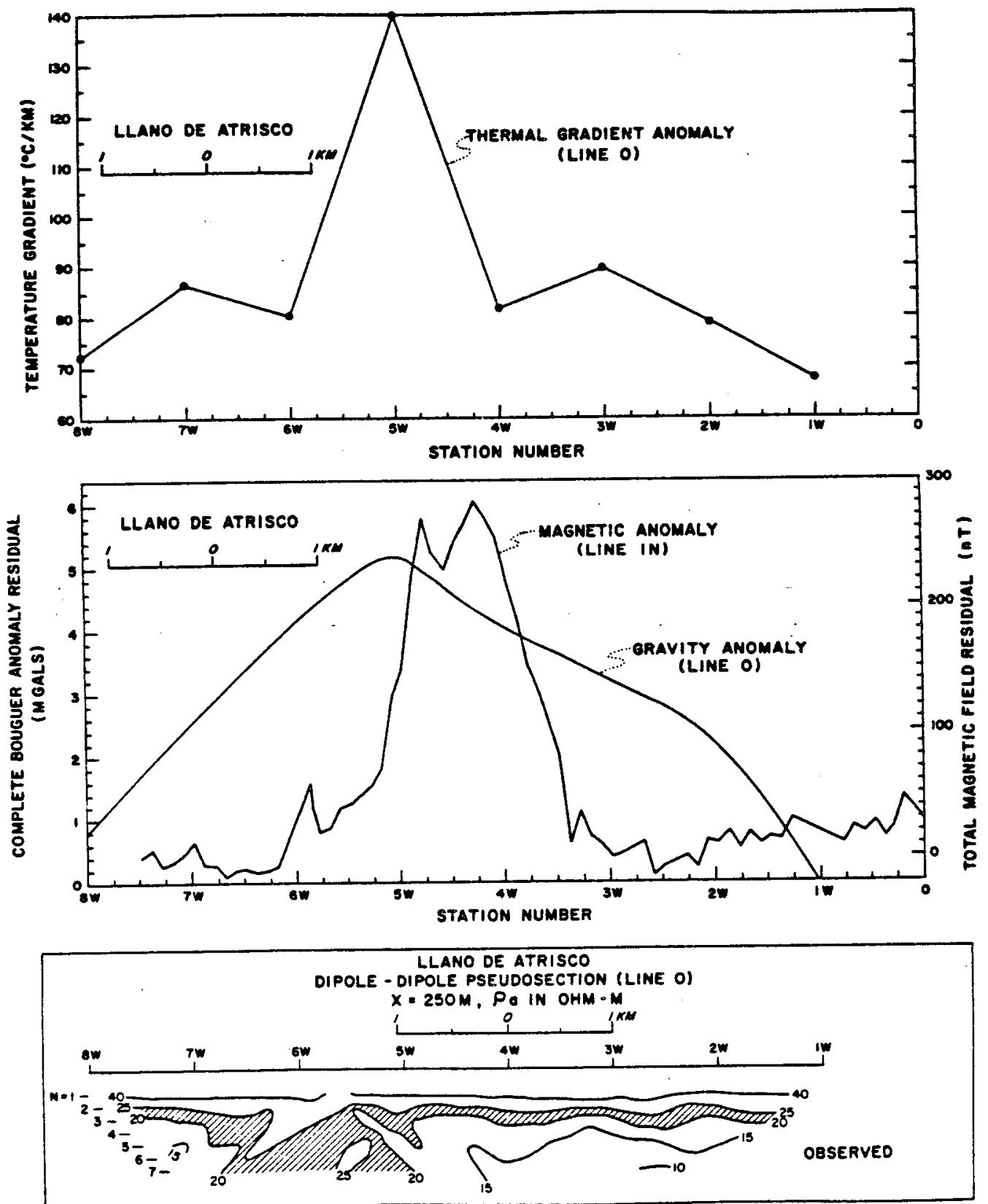

Figure 48. Profiles of shallow thermal gradient, magnetic, gravity, and resistivity surveys on Llano de Atrisco in Albuquerque area. 
pseudosection, and residual gravity profiles along Line 0 . The magnetic profile along Line $1 \mathrm{~N}, 1 \mathrm{~km}$ away, is also included. Here, it is again evident that the high resistivity anomaly between Stations $5 \mathrm{~W}$ and $7 \mathrm{~W}$ is related to the gravity anomaly and is not detecting the magnetic body. This leads to the conclusion that the causative magnetic bodies (probably lava flows) are permeable to water flow and do not act as flow barriers. Furthermore, the gravity and resistivity highs are probably sensing an upthrown block of Cretaceous basement which is relatively impermeable compared to the overlying Santa Fe beds. Minimum depth to the contact may be $200-250 \mathrm{~m}$ based on dipole-dipole modeling (Figure 42 and 43 ).

The possibility that a buried ridge rises to about $250 \mathrm{~m}$ of the surface on the west side of the Llano de Atrisco suggests an explanation for the thermal anomaly there; i.e., the forced ground-water convection model described by Morgan and Daggett (1981) and Morgan et al. (1981). In this model, heated ground water from depth is brought closer to the surface by flow over subsurface constrictions or barriers as discussed in the section on Geothermal Occurrences (Figure 8). The proposed buried ridge would be such a barrier. The large west to east hydraulic gradient discussed earlier in this area could be the driving mechanism for this heat transfer hypothesis. Since this area of the Llano de Atrisco has mapped faults (Figures 2 and 33) which are presumably deep-seated (Figure 2), we cannot rule out that all or a portion of the temperature anomaly is due to deep thermal convection. The alternate explanation of forced convection suggests a lower maximum temperature at depth, limited by the maximum depth of water circulation (Morgan et al., 1981). 
An alternative explanation for the high shallow temperature gradient anomalies mapped in Figure 34 is that they do not reflect deep conditions but are reflecting only shallow material variations. One of us (Parker) has found strong statistical correlations between temperature gradients, surface temperatures, and thermal diffusivity which measures the ability of a material to transmit heat. Consequently, varying amounts of aeolian sand, caliche, and gravels may result in varying depths of penetration of the annual temperature wave. The effect is to alter the temperature gradient predicted by least squares regression in an area of constant heat flow. Deep drilling by the U. S. Geological Survey in the area suggests that the high gradients found near-surface may not reflect a particularly high temperature source at depth.

Temperature measurements (Figure 23) of the U. S. Geological Survey water monitoring well \#1 near Line 0 , Station $4.3 W^{\circ}$ (Figure 33 ) yielded a bottom hole temperature of $32.8^{\circ} \mathrm{C}$ at $364 \mathrm{~m}$ depth. The temperature gradient below the water table $(268 \mathrm{~m}$ ) was measured (Figure 23 ) to be a linear $35^{\circ} \mathrm{C} / \mathrm{km}$. Although these temperature measurements exceed those at similar depths elsewhere in the Albuquerque area (Figures 22 and 23) they are not highly encouraging for geothermal exploitation. Our measurements of ten deep water wells on the west side of Albuquerque with depths from $110 \mathrm{~m}$ to over $440 \mathrm{~m}$ (Figure 23) have yielded only two other locations where temperatures over $30^{\circ} \mathrm{C}$ were encountered. The College \#3 well (Figure 33) has a temperature at $364 \mathrm{~m}$ depth (Figure 23) very nearly equal to that measured at the U. S. Geological Survey hole. 
A gradient of approximately $33^{\circ} \mathrm{C} / \mathrm{km}$ was measured to a total depth of 445 m. Almost $32^{\circ} \mathrm{C}$ was measured at just, $20 \mathrm{~m}$ depth in the only West Mesa well accessible for our measurements (West Mesa \#4, Figure 23). This anomalous temperature was due to distortion from active pumping of the well prior to our measurements. Here, warm water pumped from depth greatly enhanced the temperature in the upper portion of the well. We were unable to obtain an equilibrium gradient in this well but obviously deep temperatures are greater than or equal to $32^{\circ} \mathrm{C}$. The well was drilled to $436 \mathrm{~m}$.

The U. S. Geological Survey water monitoring well was postioned in the vicinity of our Line 0 , Station $4.3 \mathrm{~W}$ because of the possible geothermal significance. Positioning of the hole to the west of Station $5 W$ (at about Line 0, Station 5.5W) appeared to be a better geothermal choice based on resistivity modeling (Figure 42 ). However, the site drilled was more readily accessible.

It is interesting to note that the well record of the nearby Carpenter \#1 Atrisco well (Figures 33 and 34) lists zones of "large volumes of water" at depths of 671,899 , and 1,003 $\mathrm{m}$. Extrapolation of the temperature gradient from the U. S. Geological Survey well leads to expected temperatures of 44,51 , and $55^{\circ} \mathrm{C}$ at these depths, respectively. Thus, the possibility of a low temperature $\left(>50^{\circ} \mathrm{C}\right)$ geothermal resource does exist at reasonable depths $(<1 \mathrm{~km})$ west of Albuquerque. 


\section{REFERENCES}

Bachman, G. 0., Marvin, R. F., Mehnert, H. H., and Merritt, V., 1975, $\mathrm{K}-\mathrm{Ar}$ ages of the basalt flows at Los Lunas and Albuquerque, central New Mexico: Isochron/West, no. 13, p. 3-4.

Bachman, G. 0., and Mehnert, H. H., 1978, New K-Ar dates and the late Pliocene to Holocene geomorphic history of the central Rio Grande region, New Mexico: Geol. Soc. America Bul1., v. 89, p. 283-292. Bhattacharyya, B. K., 1964, Magnetic anomalies due to prism-shaped bodies with arbitrary polarization: Geophysics, v. 29, no. 4, p. $517-531$.

Birch, F. S., 1980, Geophysical evaluation of basin hydrologic characteristics in the central Rio Grande, Part I, Gravity models of the Albuquerque-Belen basin: Final Rept. on U. S. Geol. Survèy Contract No. 14-08-00001-17879, $30 \mathrm{p}$.

Birch, F. S., 1982, Gravity models of the Albuquerque basin, Rio Grande rift, New Mexico: Geophysics, v. 47, no. 8, p. 1185-1197. Bjorklund, L. J., and Maxwell, B. W., 1961, Availability of ground water in the Albuquerque area, Bernalillo and Sandoval Counties, New Mexico: New Mexico State Engineer Tech. Rept. 21, 117 p. Blackwell, D. D., and Chapman, D. S., 1977, Interpretation of geothermal gradient and heat flow data for Basin and Range geothermal systems: Geothermal Resources Council, Trans., v. 1, p. 19-20.

Blackwel1, D. D., Steele, J. L., and Brott, C. A., 1980, The terrain effect on terrestrial heat flow: Jour. Geophys. Res., v. 85, no. B9, p. $4757-4772$. 
Brandwein, S. S. 1974, Selected shallow electrical resistivity surveys at Volcano Cliffs, Bernalillo County, and Warm Springs, Sandoval County, New Mexico: Univ. New Mexico, Albuquerque, unpub. M. S. thesis, $139 \mathrm{p}$.

Brown, L. D., Chapin, C. E., Sanford, A. R., Kaufman, S., and 01 iver, J., 1980, Deep structure of the Rio Grande rift from seismic reflection profiling: Jour. Geophys. Res., v. 85 , no. 89 ; p. 4773-4800.

Callender, J. F., and Zilinski, R. E., 1976, Kinematics of Tertiary and Quaternary deformation along the eastern edge of the Lucero Uplift, central New Mexico: New Mexico Geol. Soc. Spec. Pub. 6, p. 53-61.

Chapin, C. E., Chamberlin, R. M., Osburn, G. R., Sanford, A. R., and White, D. W., 1978, Exploration framework of the Socorro geothermal area, New Mexico, in Field guide to selected cauldrons of the Datil-Mogollon volcanic field New Mexico: New Mexico Geol. Soc. Spec. Pub. 7, p. 115-129.

Cordell, L., Keller, G. R., and Hildenbrand, T. G., 1978, Complete Bouguer gravity anomaly map of the Rio Grande rift: U. S. Geol. Survey open-file map 78-958.

Dey, A., 1976, Resistivity modeling for arbitrarily shaped two-dimensional structures, Part II: User's guide to the FORTRAN algorithm RESIS2D: Lawrence Berkeley Laboratory, Report LBL-5283, University of California, Berkeley.

Fournier, R. 0., and Potter, R. W., II, 1979, Magnesium correction to the $\mathrm{Na}-\mathrm{K}-\mathrm{Ca}$ chemical geothermometer: Geochem. Cosmochim. Acta, v. 43, p. $1543-1550$. 
Harder, V. Morgan, P., and Swanberg, C. A., 1980, Geothermal resources

in the Rio Grande rift: origins and potential: Geothermal

Resources Counci1, Trans., v. 4, p. 61-64.

Hiss, W. L., Trainer, F. W., Black, B. A., and Posson, D. R., 1975,

Chemical quality of ground water in the northern part of the

Albuquerque-Belen basin, Bernalillo and Sandoval Counties, New

Mexico, in Guidebook to Las Cruces country: New Mexico Geo1. Soc.,

26th Field Conf., p. 219-236.

Jaksha, L. H., Locke, J., and Gebhart, H. T., 1981, Microearthquakes

near the Albuquerque volcanoes, New Mexico: Geol. Soc. America

Bu11., pt. 1, v. 92, p. 31-36.

Jiracek, G. R., 1982, Geophysical evaluation of basin hydrological

characteristics in the central Rio Grande rift, Part III, Electrical

resistivity investigations: Final Rept. on U. S. Geol. Survey

Contract No. 14-08-0001-17879, 109 p.

Jiracek, G. R., Gustafson, E. P., and Parker, M. D., 1982, Geophysical

exploration for geothermal prospects west of Albuquerque, New

Mexico: in Guidebook to Albuquerque Country II: New Mexico Geol.

Soc., 33rd Field Conf., p. 333-342.

Kasten, J. A., 1977, Petrology and geochemistry of calc-alkaline

andesites within the Albuquerque basin, Valencia County, New Mexico:

Univ. New Mexico, Albuquerque, unpub. M. S. thesis, 79 p.

Kauffman, D., and Houghton, A. V., 1979, Low temperature geothermal

energy applications in the Albuquerque, New Mexico area: New Mexico

Energy and Minerals Dept. EMD-78-2122, 180 p. 
Kauffman, D., and Houghton, A. V., 1980, Engineering and economic evaluation of direct hot-water geothermal energy applications on the University of New Mexico campus: Bureau of Engineering Res., Univ. New Mexico, Final Rept. on DOE/ID/12048-4, 245 p.

Kelly, T. E., 1982, History of water use in the greater Albuquerque area: in Guidebook to Albuquerque Country II, New Mexico Geol. Soc., 33rd Field Conf., p. 351-355.

Kelly, T. E., Myers, B. N., and Hershey, L. A., 1974, Reconnaissance investigation of ground water in the Rio Grande drainage basin with special emphasis on saline ground-water resources: U. S. Geol. Survey Hydrol. Inv. Atlas HA-150.

Kelley, V. C., 1977, Geology of Albuquerque basin, New Mexico: New Mexico Bur. Mines and Mineral Resources Mem. 33, $60 \mathrm{p}$. Kelley, V. C., 1982, The right-relayed Rio Grande rift, Taos to Hatch, New Mexico: in Guidebook to Albuquerque Country II, New Mexico Geol. Soc., 33rd Field Conf., p. 147-151.

Kelley, V. C., and Kudo, A. M., 1978, Volcanoes and related basalts of the Albuquerque basin, New Mexico: New Mexico Bur. Mines and Min. Res. Circ. 156, 30 p.

Kudo, A. M., 1982, Rift volcanics of the Albuquerque basin, Overview with some new data: in Guidebook to Albuquerque Country II, New Mexico Geol. Soc., 33rd Field Conf., p. 285-289.

Lange, A. L., Pilkington, H. D., and Deymonaz, J., 1982, Comparative studies of geothermal surveys in 3-meter and temperature-gradient holes: Geothermal Resources Council, Trans., v. 6, p. 133-136. Machette, M. N., 1978, Bernalillo County dump fault, in New Mexico Bur. Mines and Mineral Resources Cir. 163: p. 153-155. 
Morgan, P., and Daggett, P. H., 1981, Active and passive seismic studies of geothermal resources in New Mexico and investigations of earthquake hazards to geothermal development: New Mexico Energy Research and Development Programs, Final Tech. Rept., EMD 77-2203, $50 \mathrm{p}$.

Morgan, P., Harder, V., Swanberg, C. A., and Daggett, P. H., 1981, A groundwater convection model for Rio Grande rift geothermal resources: Geothermal Resources Council, Trans., v. 5, p. 193-196. Parker, M. D., and Jiracek, G. R., 1980, Progress toward evaluating the geothermal resource in the Albuquerque, New Mexico area: Geothermal Resources Council, Trans., v. 4, p. 229-232.

Reeder, H. 0., Bjorklund, L. J., and Dinwiddie, G. A., 1967, Quantitative analysis of water resources in the Albuquerque area, New Mexico, computed effects on the Rio Grande of pumpage of ground water, 1960-2000: New Mexico State Engineer Tech. Rept. 33, 34 p. Reilinger, R., Oliver, J., Brown, L., Sanford, A., and Balazs, E., 1980, New measurements of crustal doming over the Socorro magma body, New Mexico: Geology, v. 8, p. 291-295.

Reiter, M. A., Edwards, C. L., Hartman, H., and Weidman, C., 1975, Terrestrial heat flow along the Rio Grande rift, New Mexico and Southern Colorado: Geol. Soc. America Bul1., v. 86, no. 6, p. 811-818.

Reiter, M., and Smith, R., 1977, Subsurface temperature data in the Socorro Peak KGRA, New Mexico: Geothermal Energy, v. 5, no. 10, p. $37-42$.

Reiter, M., Shearer, C., and Edwards, C. L., 1978, Geothermal anomalies along the Rio Grande rift in New Mexico: Geology, v. 6, p. 85-88. 
Reiter, M., Mansure, A. J., and Shearer, C., 1979, Geothermal characteristics of the Rio Grande rift within the southern Rocky Mountain complex, in Riecker, R. E., ed., Rio Grande rift:

Tectonics and magmatism: Washington, D. C., American Geophysical Union, p. 253-265.

Riddle, L., and Grant, B., 1981, Geothermal studies at Kirtland Air

Forces Base, Albuquerque, New Mexico: Sandia National Laboratories Rept. SAND81-0852, $50 \mathrm{p}$.

Roy, R. F., Blackwe11, D. D., and Decker, E. R., 1972, Continental heat flow, in Robertson, E. C., ed., Nature of the solid earth: McGraw-Hi11, New York, p. 506-543.

Russell, L., Structural style of the Rio Grande rift in the vicinity of the COCORP survey with comparison to Basin and Range structure in northeast Nevada: paper presented at International Sym. on the Rio Grande rift, Inter-Union Comm. on Geodyn., Santa Fe, New Mexico, 1978.

Sanford, A. R., Mott, R. P., Jr., Shuleski, P. J., Rinehart, E. J., Caravella, F. J., Ward, R. M., and Wallace, T. C., 1977, Geophysical evidence for a magma body in the crust in the vicinity of Socorro, N. M., in Heacock, J. G., ed., The Earth's crust, Geophys Monogr. Series, v. 20, Washington, D. C., American Geophysical Union, p. 385-403.

Sanford, A. R., 01 sen, K. H., and Jaksha, L. H., 1979, Seismicity of the Rio Grande rift, in Riecker, R. E., ed., Rio Grande rift: Tectonics and magmatism: Washington, D. C., American Geophysical Union, p. $145-168$. 
Spiege1, Z. E., 1955, Geology and groundwater resources of northwestern Socorro County, New Mexico: New Mexico Bur. Mines and Mineral Resources Ground-Water Rept. 4, 99 p.

Spiegel, Z., and Baldwin, B., 1963, Geology and water resources of the Santa Fe area, New Mexico: U. S. Geol. Survey Water-Supply Paper $1525,258 p$.

Stone, W. J., and Mizel1, N. H., 1977, Geothermal resources of New Mexico - a survey of work to date: New Mexico Bur. Mines and Mineral Resources, Open-file Rept. 73, 19 p.

Summers, W. K., 1976, Catalog of thermal waters in New Mexico: New Mexico Bur. Mines and Mineral Resources, Hydrologic Rept. 4, 80 p.

Swanberg, C. A., 1975, Detection of geothermal components in groundwaters of Dona Ana County, southern Rio Grande rift, New Mexico: in Guidebook to Las Cruces Country, New Mexico Geol. Soc., 26th Field Conf., p. 175-180.

Swanberg, C. A., and Alexander, S., 1979, The use of the water quality file WATSTORE in geothermal exploration: an example from the Imperial Valley, California, Geology, v. 7, p. 108-111.

Swanberg, C. A., and Morgan, P., 1980, The silica heat flow interpretation technique: assumptions and applications: Jour. Geophys. Res., v. 85, p. 7206-7214.

Titus, F. B., Jr., 1963, Geology and ground-water conditions in eastern Valencia County, New Mexico: New Mexico Bur. Mines and Mineral Resources Ground-Water Rept. 7, $113 \mathrm{p}$.

Trainer, F. W., and Lyford, F. P., Geothermal hydrology in the Rio Grande rift, north-central New Mexico: in Guidebook to Santa Fe County: New Mexico Geol. Soc., 30th Field Conf., p. 299-306. 
Truesdell, A. H., 1976, Summary of section III, Geochemical techniques in exploration: Proc. 2nd United Nations Symp. on devel. and use of geothermal resources, San Francisco, California, v. 1, Washington, D. C., p. liii-1xxix.

Vacquier, V., Steenland, N. C., Henderson, R. G., and Zietz, I., 1951, Interpretation of aeromagnetic maps: Geol Soc. of Amer. Mem. 47, $151 \mathrm{p}$.

Wright, A. F., 1978, Bibliography of the geology and hydrology of the Albuquerque greater urban area, Bernalillo and parts of Sandoval, Santa Fe, Socorro, Torrance, and Valencia Counties, New Mexico: U. S. Geol. Survey Bu11. 1458, $31 \mathrm{p}$.

Zilinski, R. E., Jr., 1976, Geology of the central part of the Lucero uplift, Valencia County, New Mexico: Univ. New Mexico, Albuquerque, unpub. M. S. thesis, $69 \mathrm{p}$.

Zohdy, A. A. R., 1973, A computer program for the automatic interpretation of Schlumberger sounding curves over horizontally stratified media: Nat. Tech. Inform. Serv. (Springfield, Virginia 22151), no. PB-232 703, $25 \mathrm{p}$.

Zohdy, A. A. R., 1978, Total field resistivity mapping and sounding over horizontally layered media: Geophysics, v. 43, p. 748-766. Zohdy, A. A. R., and Stanley, W. D., 1974, A computer program for the calculation of bipole-dipole apparent resistivity maps over horizontally stratified media: Nat. Tech. Inform. Serv. (Springfield, Virginia 22151), PB-232 727/AS, $10 \mathrm{p}$. 


\section{APPENDIX A}

\section{Shallow Temperature Gradient Measurements}

in the Albuquerque Area

(Locations of drillholes shown in Figures 20, 24, and 34 of text.) 

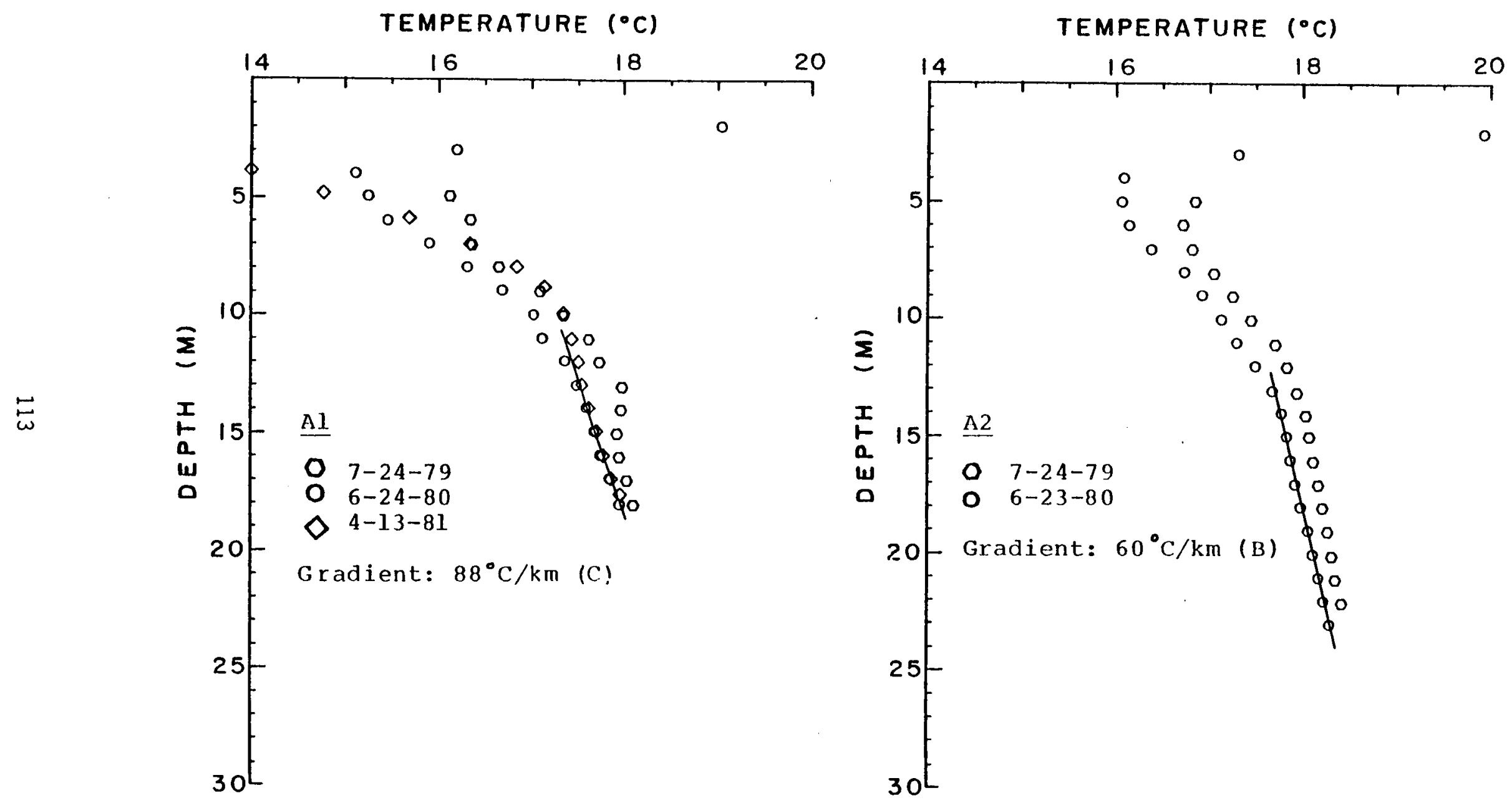


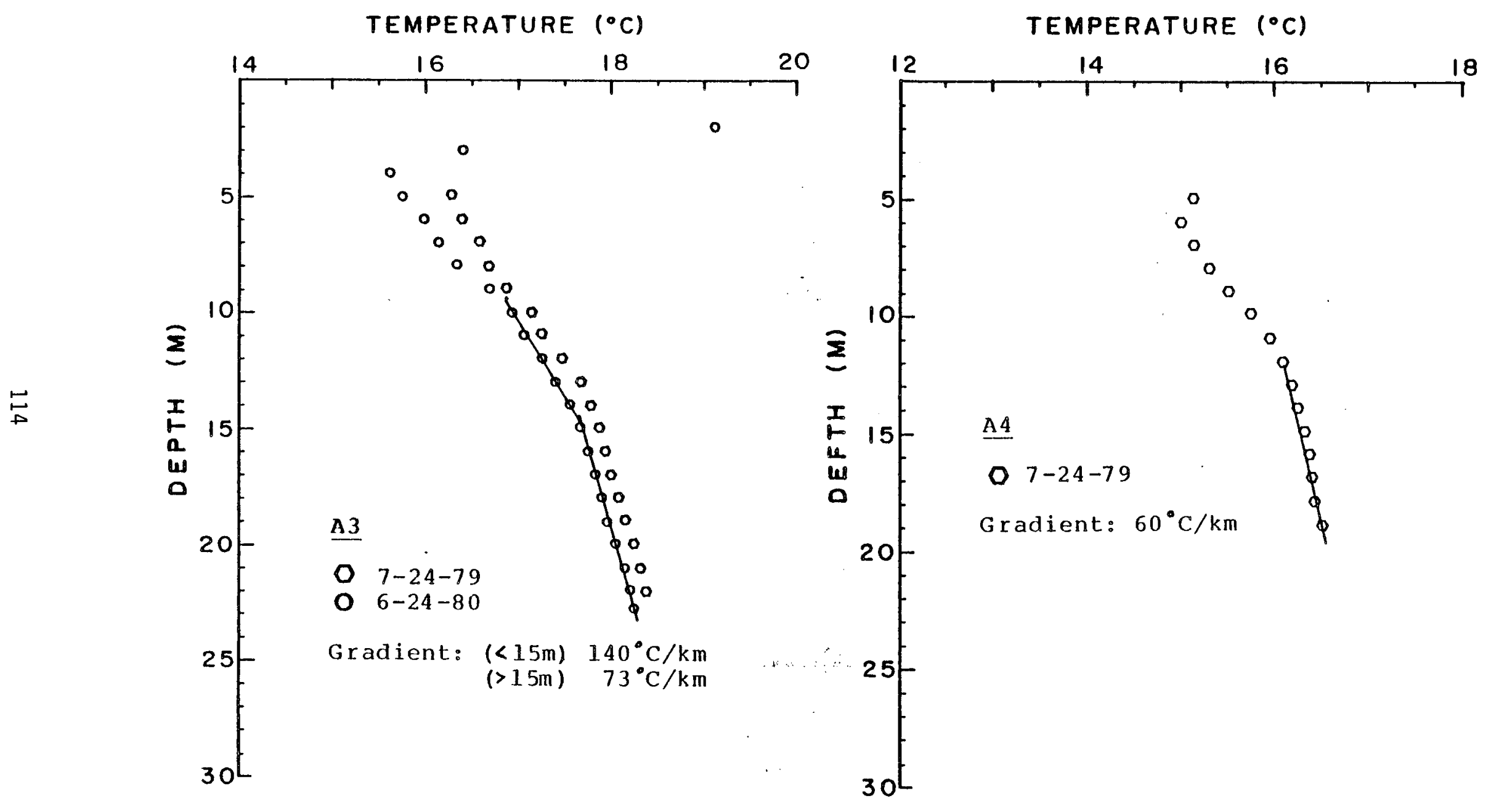



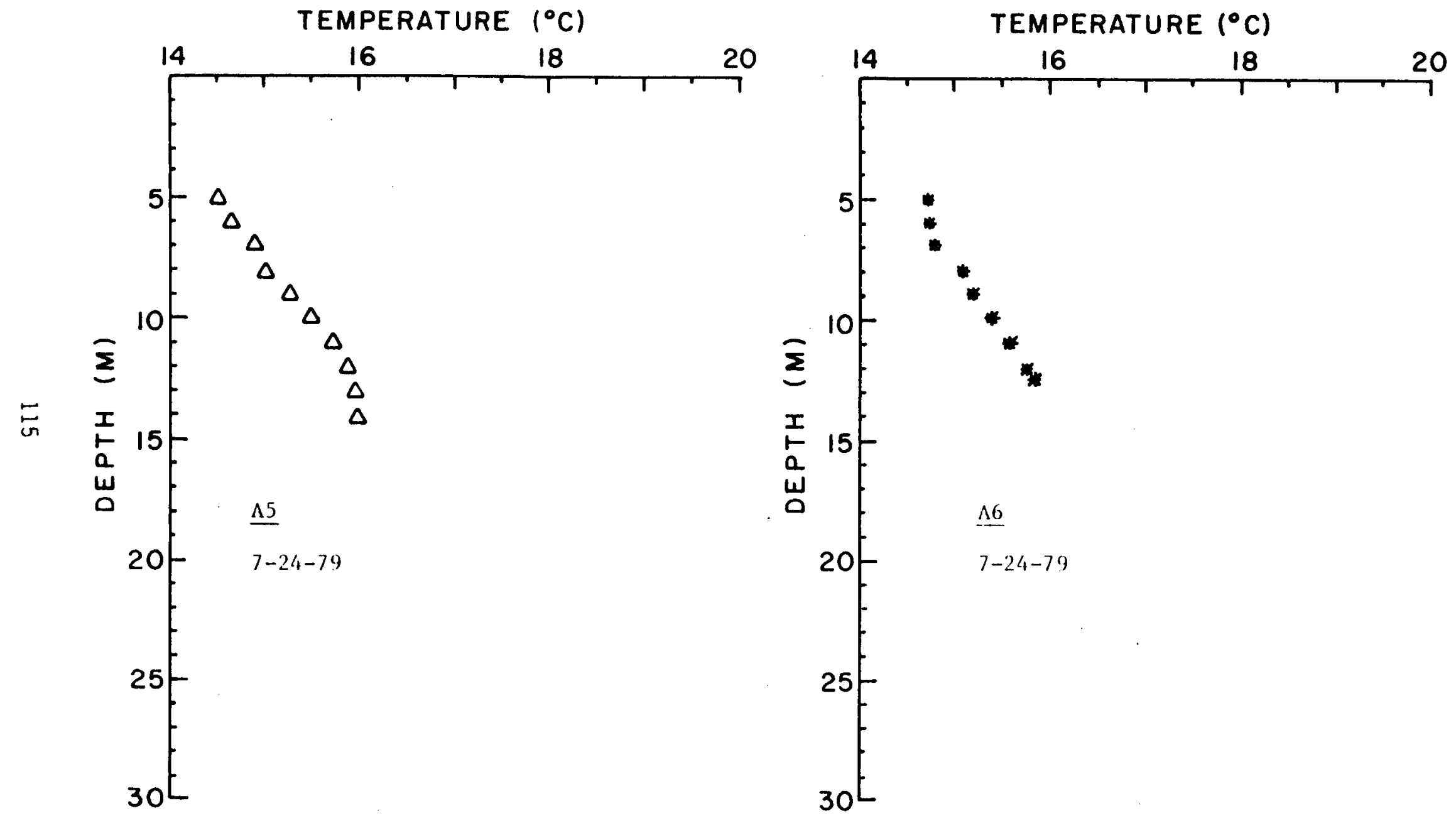

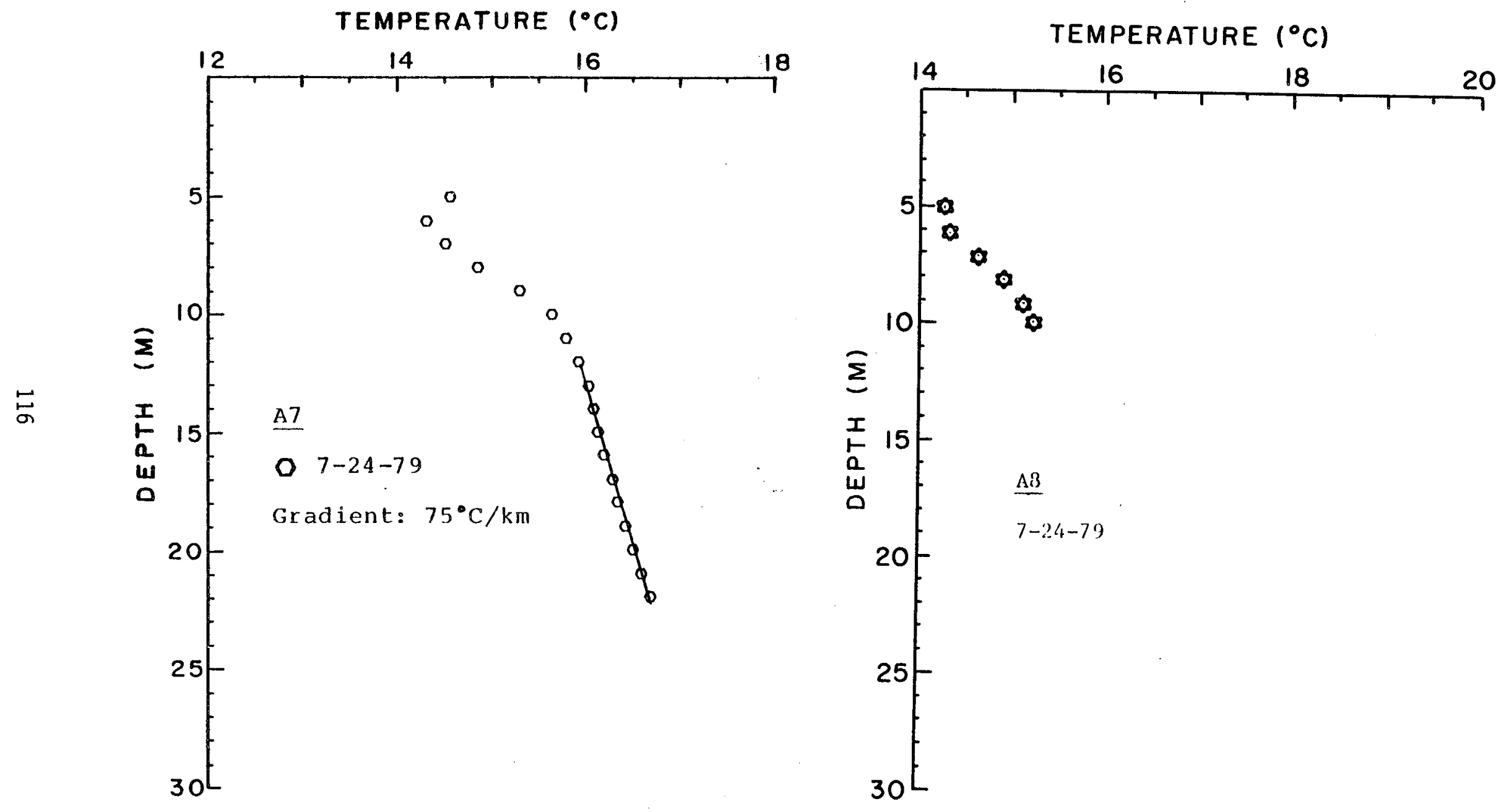

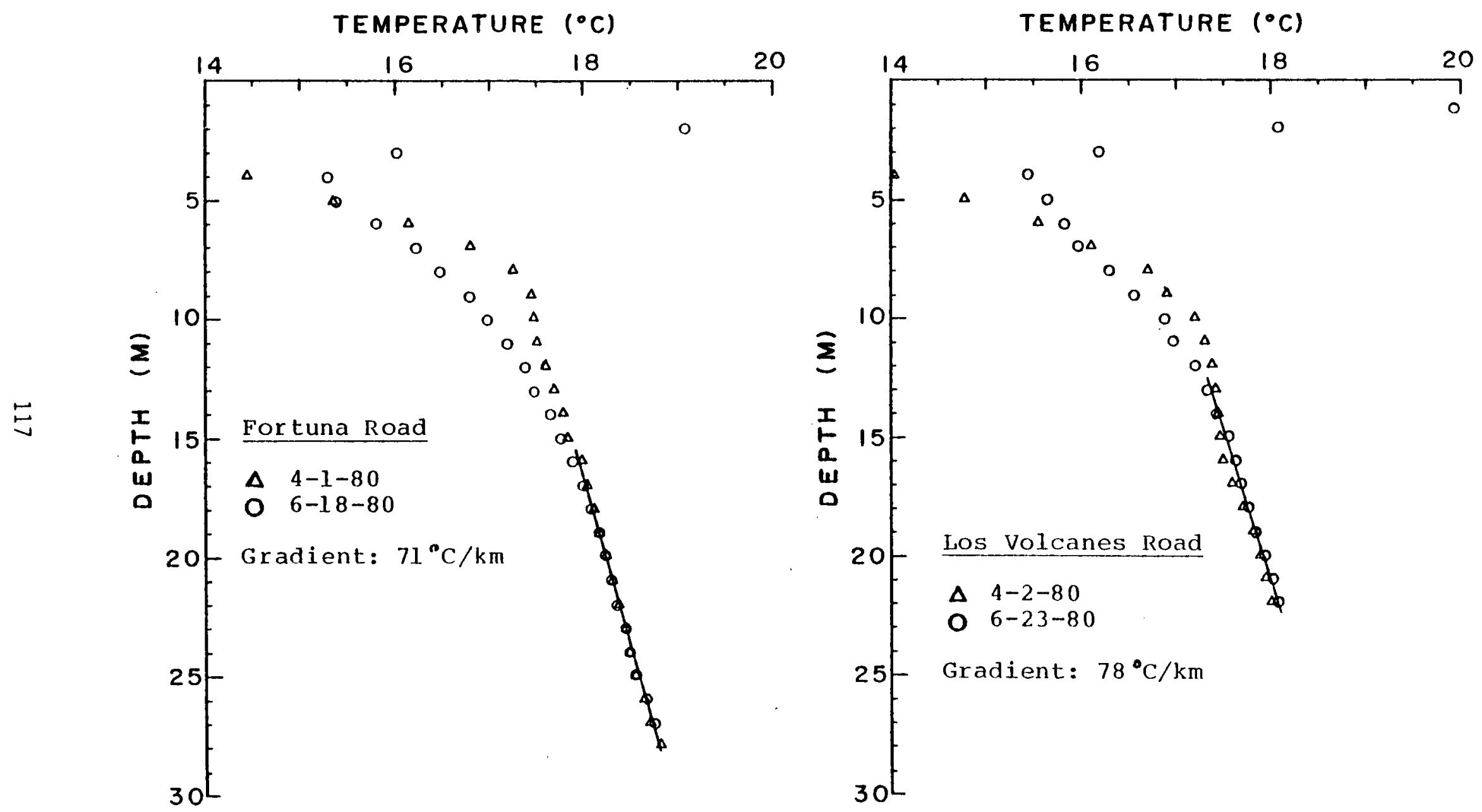


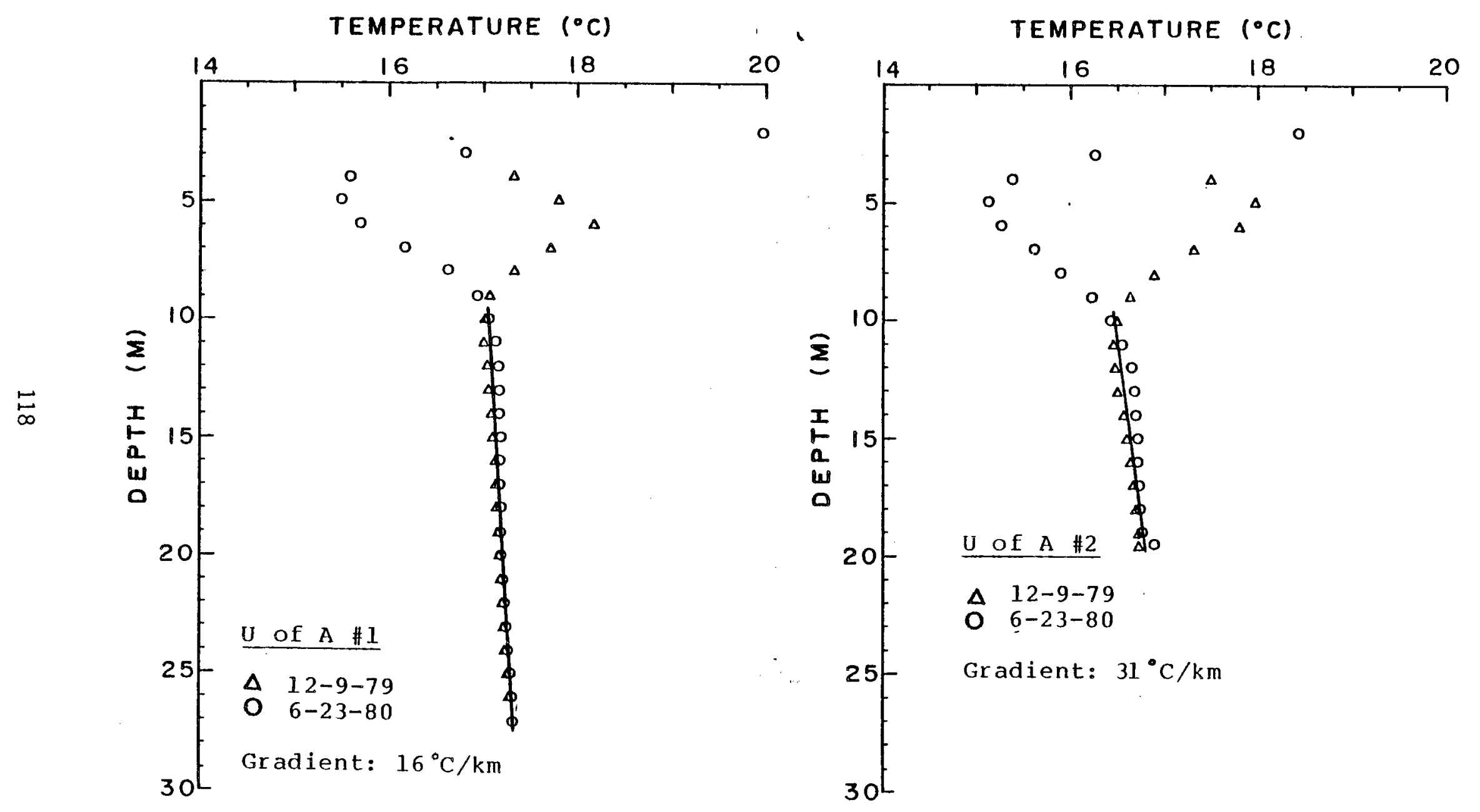



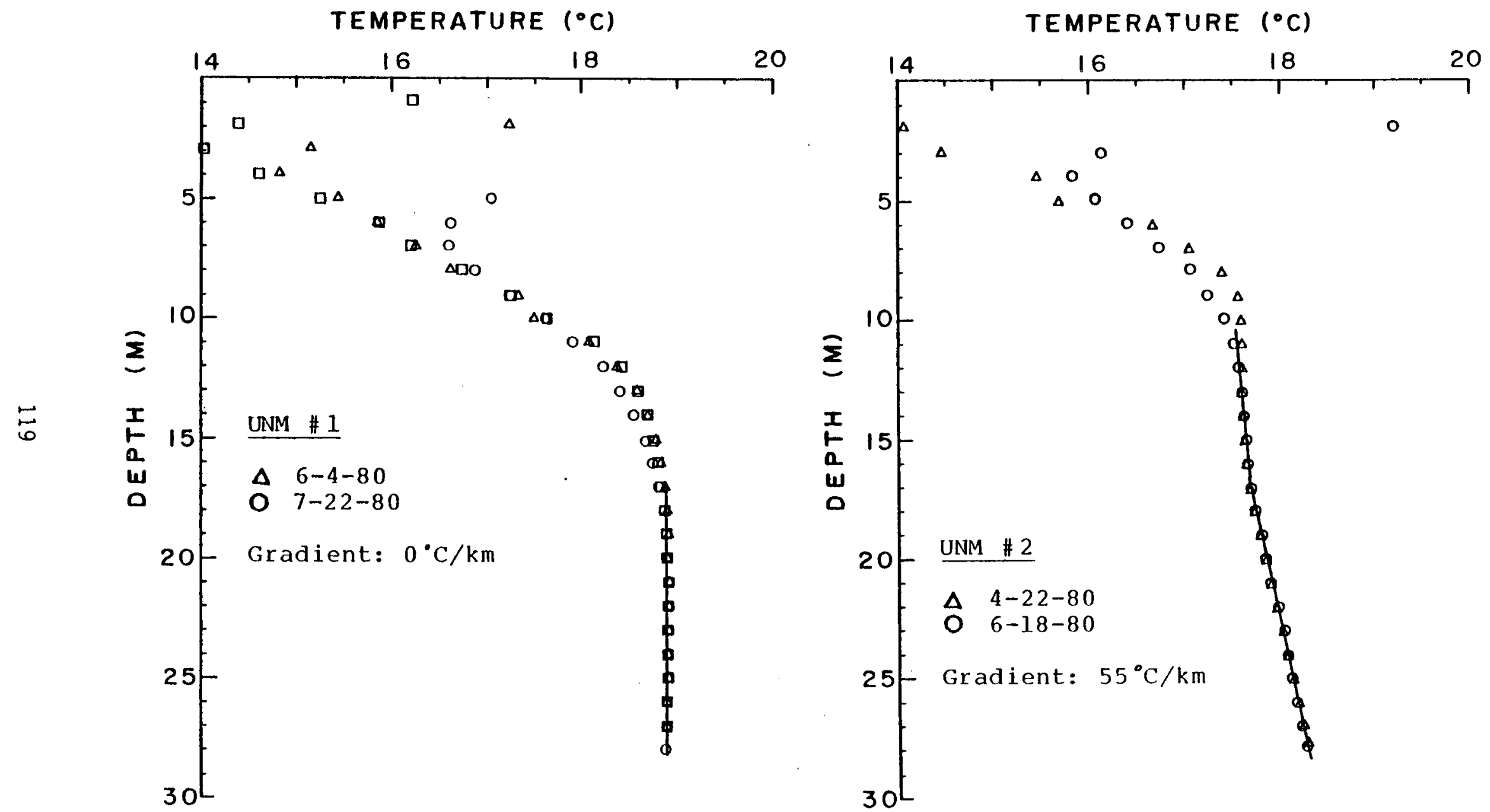
TEMPERATURE $\left({ }^{\circ} \mathrm{C}\right)$

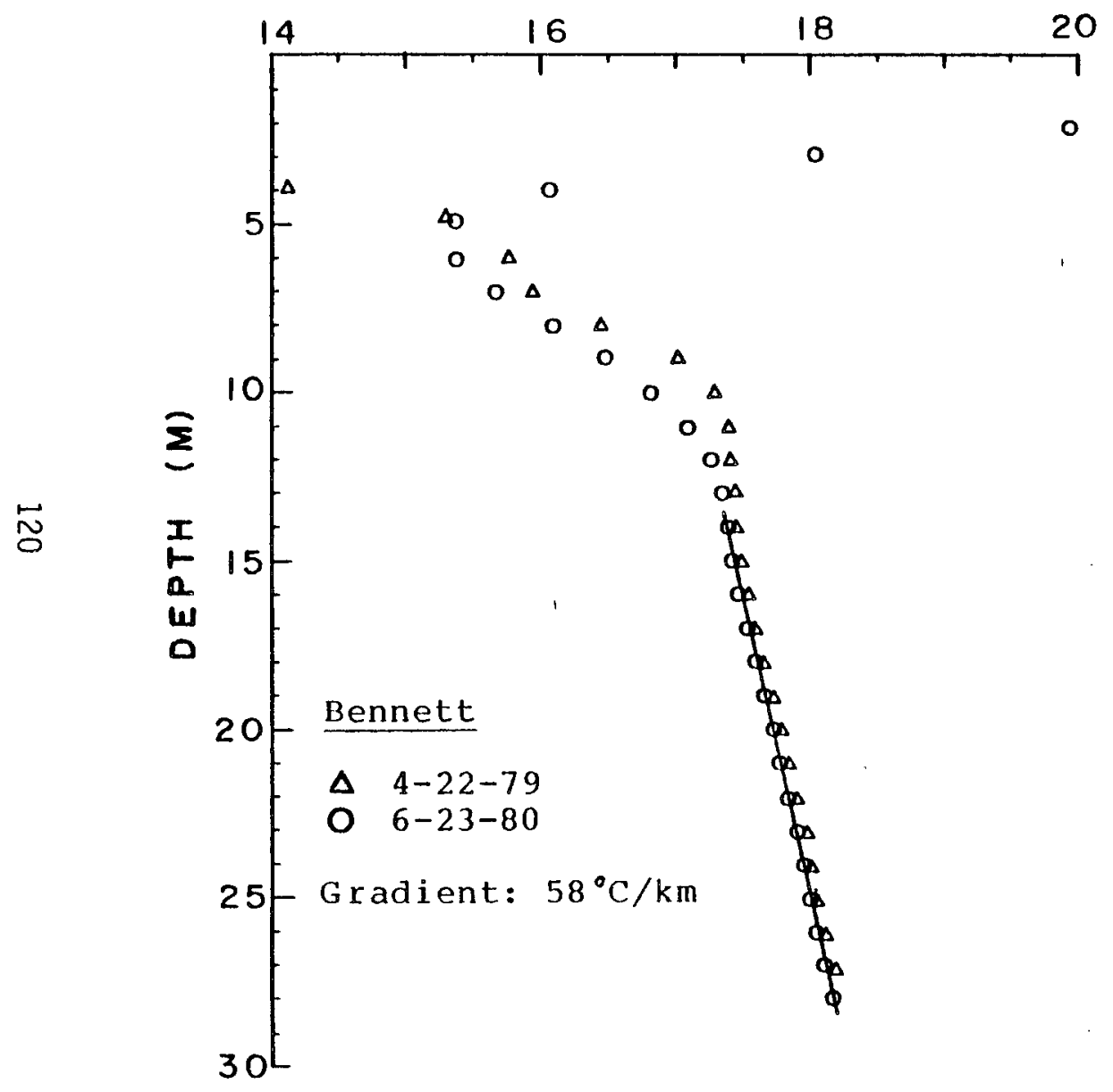

TEMPERATURE $\left({ }^{\circ} \mathrm{C}\right)$

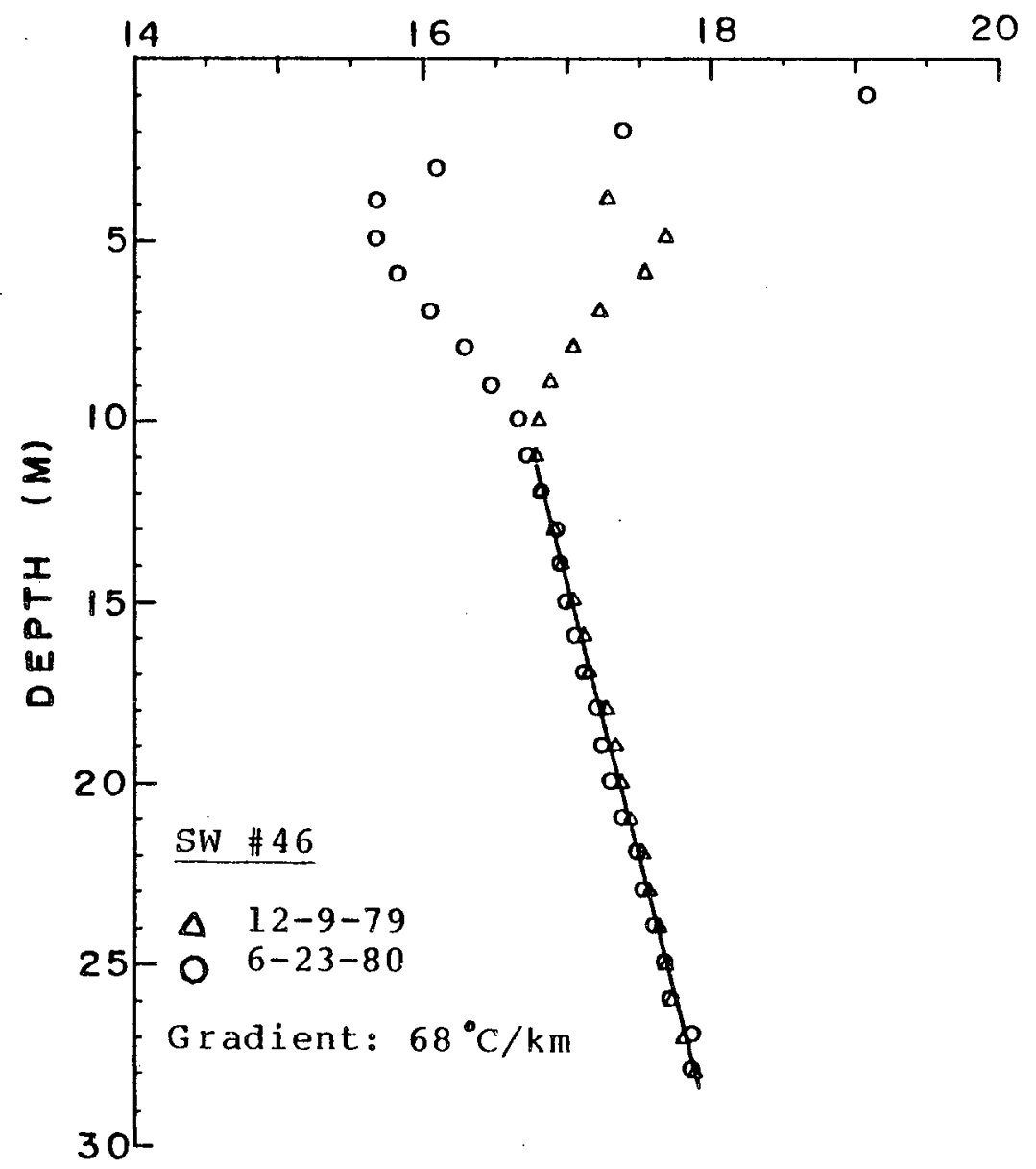


TEMPERATURE $\left({ }^{\circ} \mathrm{C}\right)$

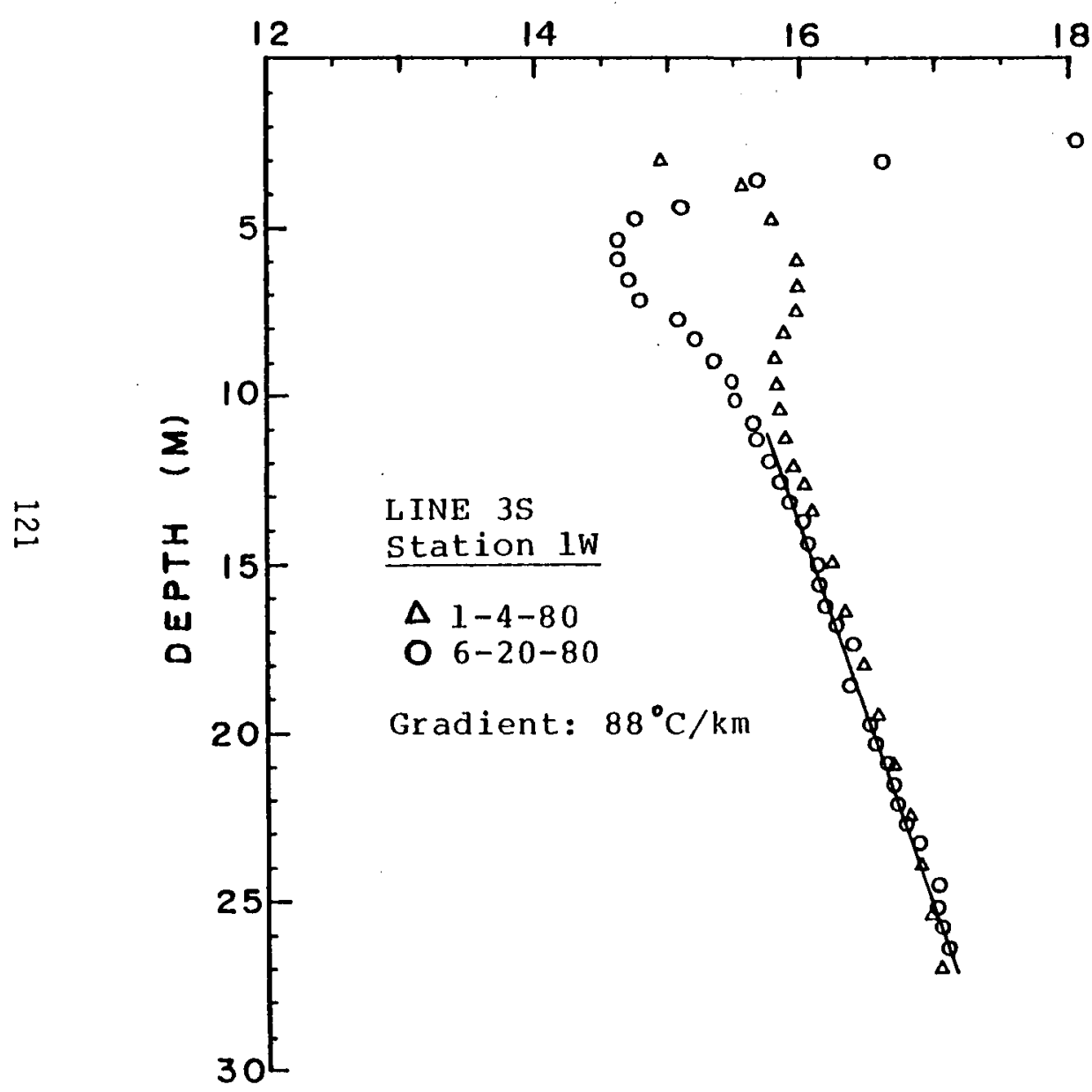

TEMPERATURE $\left({ }^{\circ} \mathrm{C}\right)$

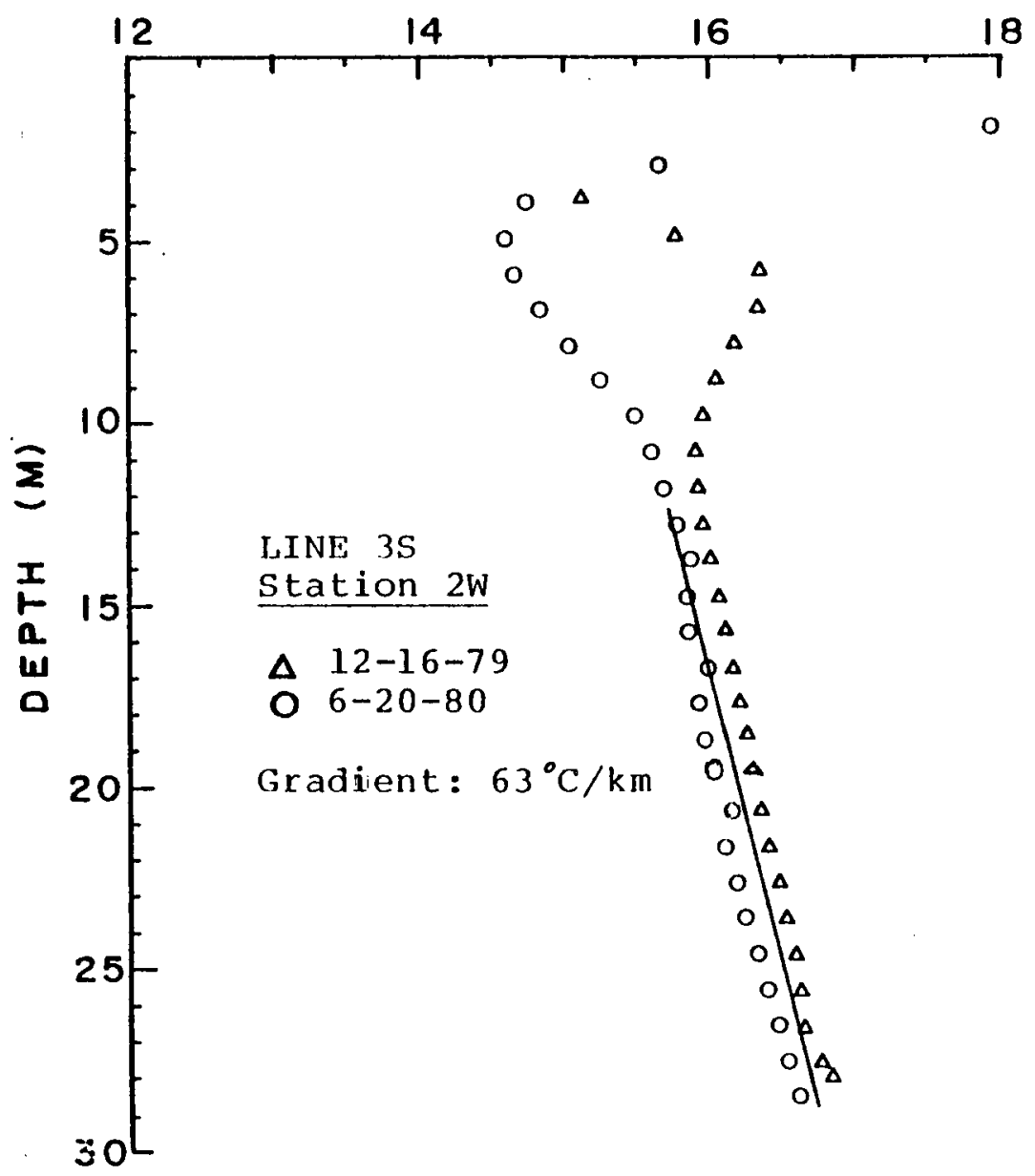




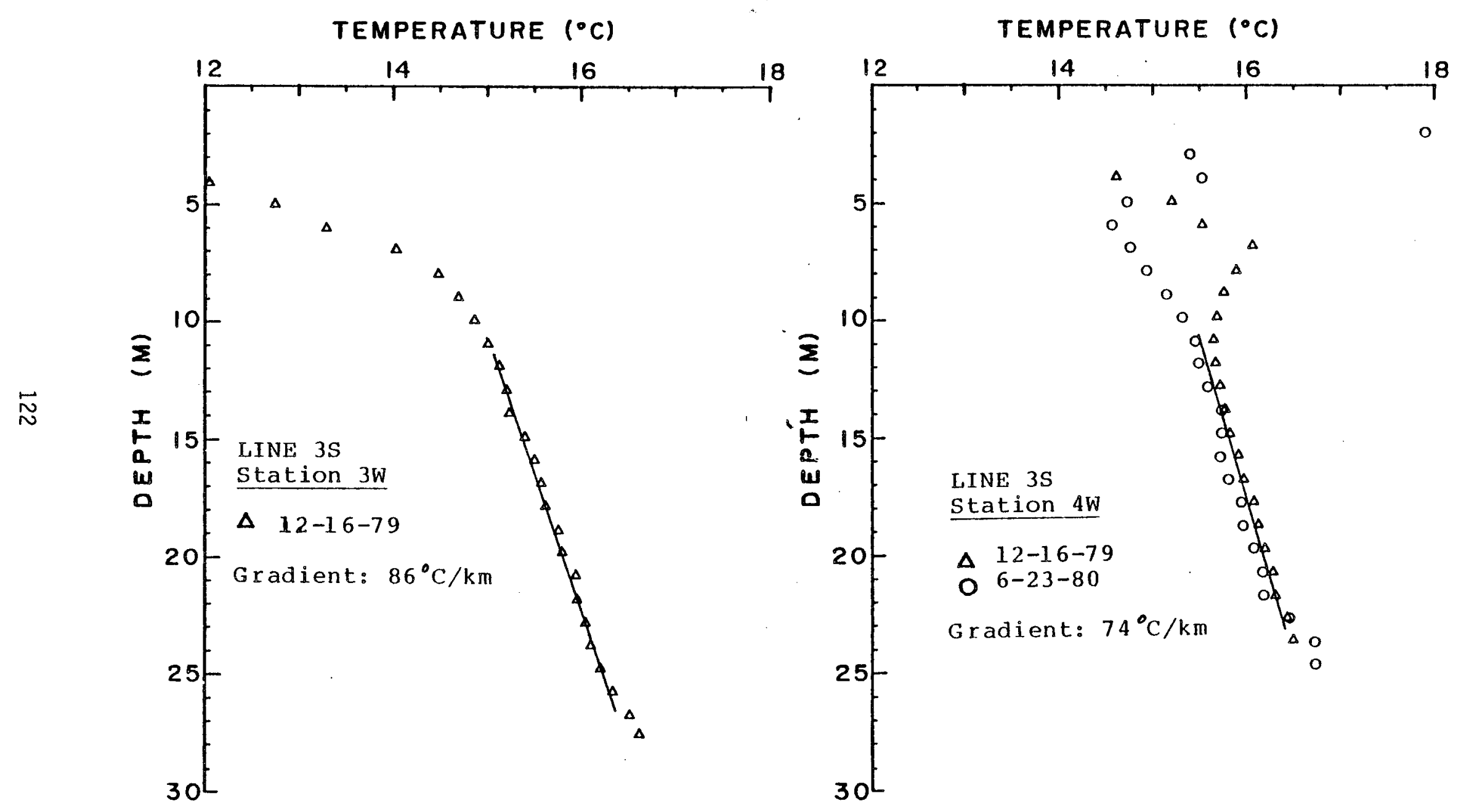



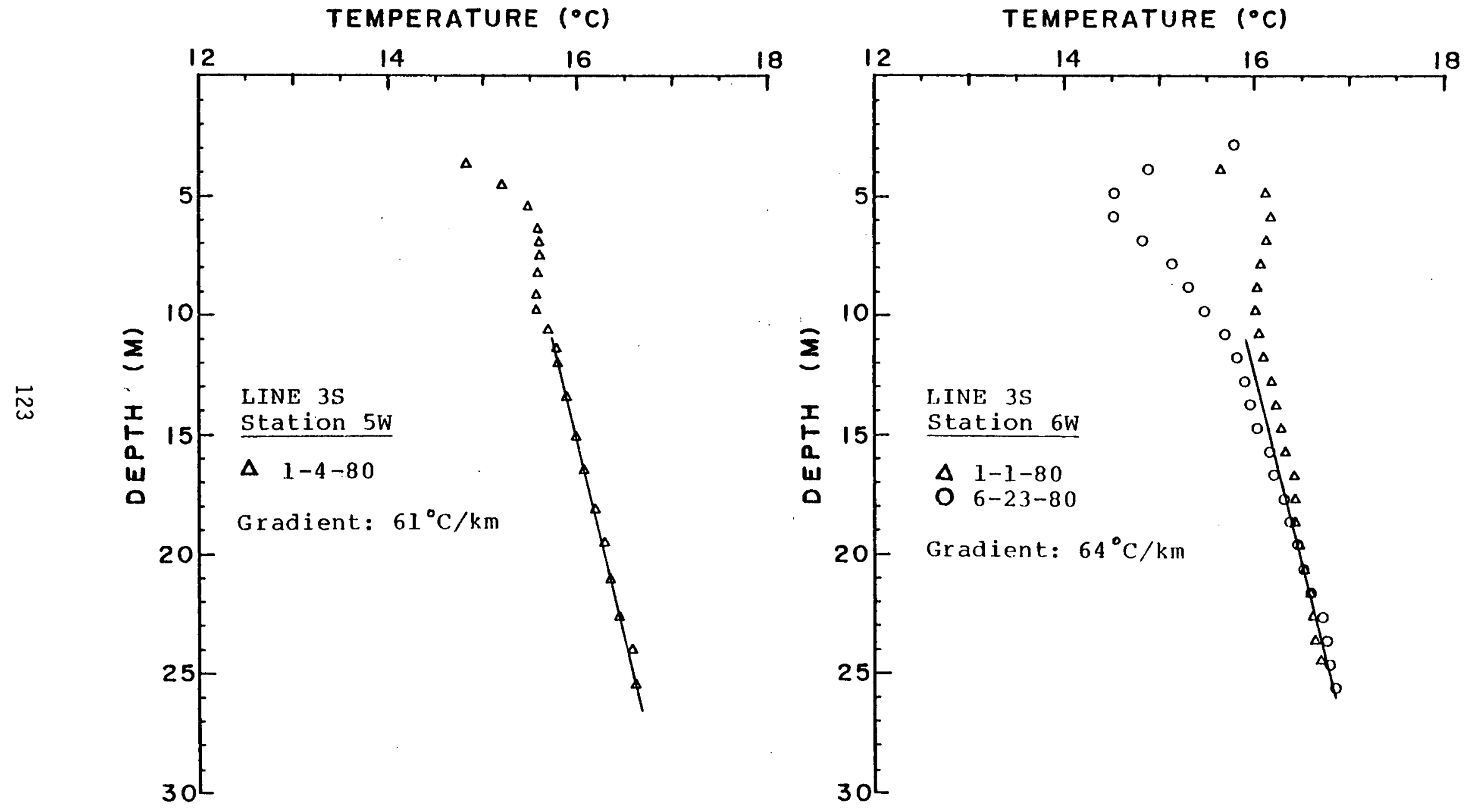


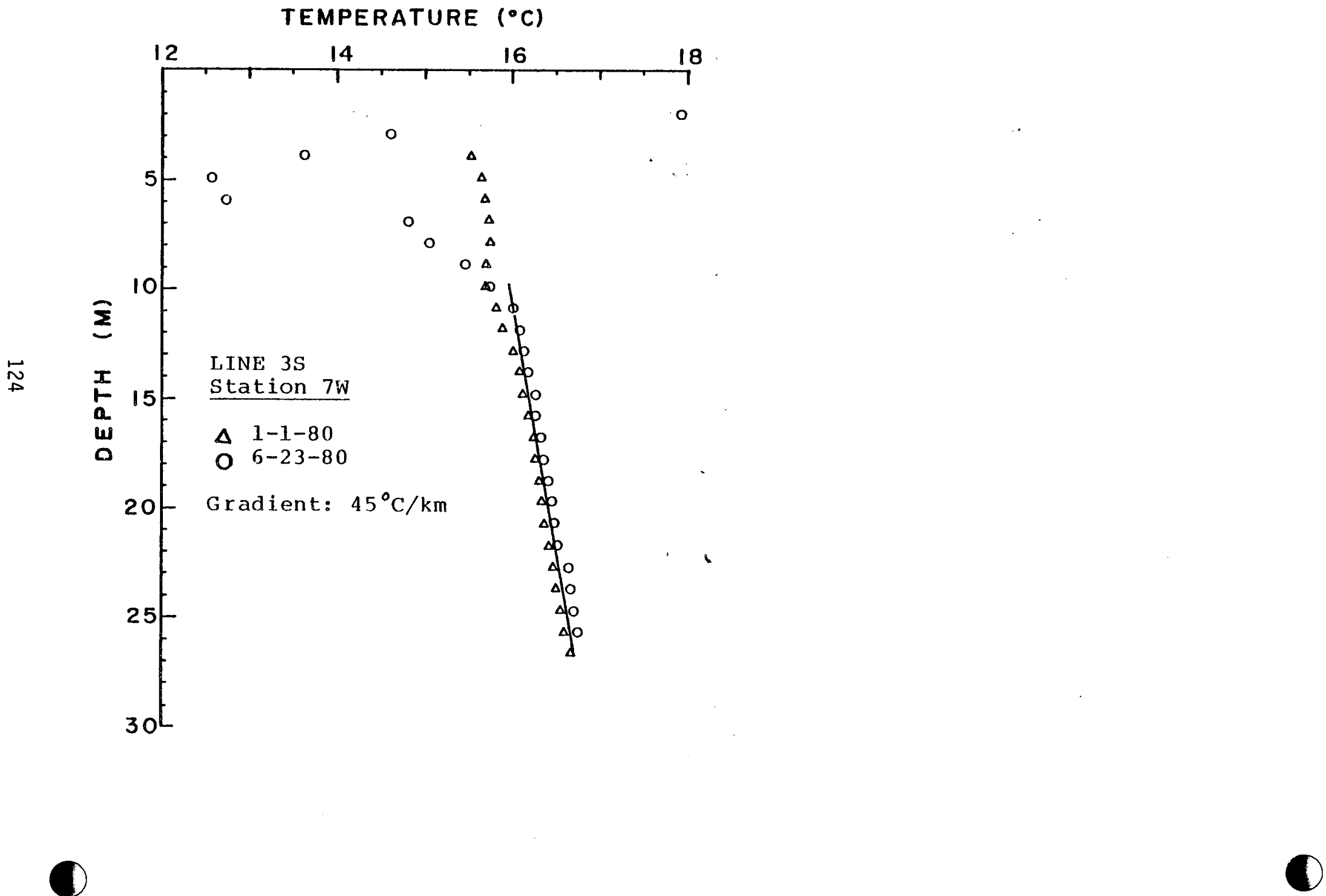



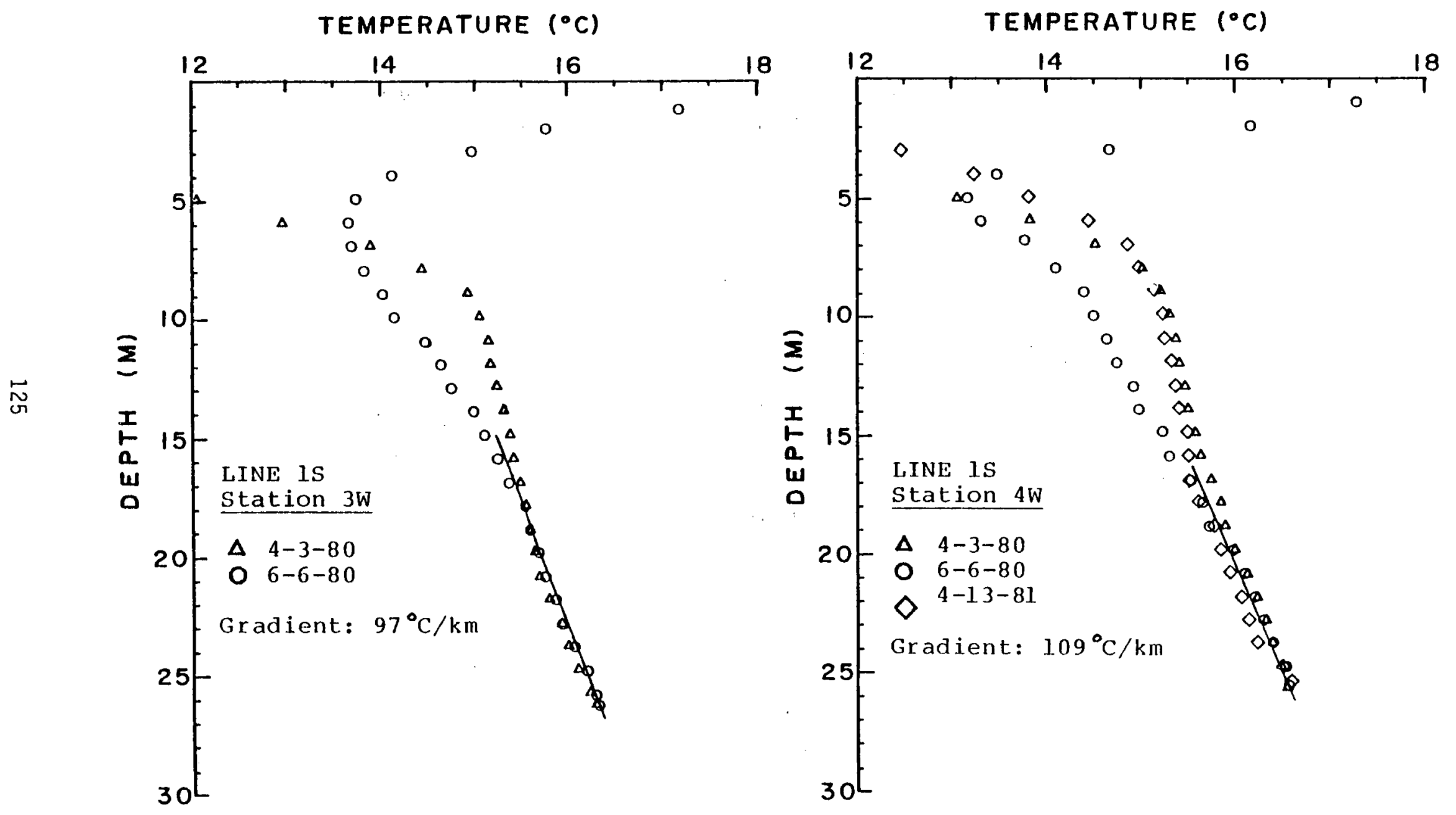


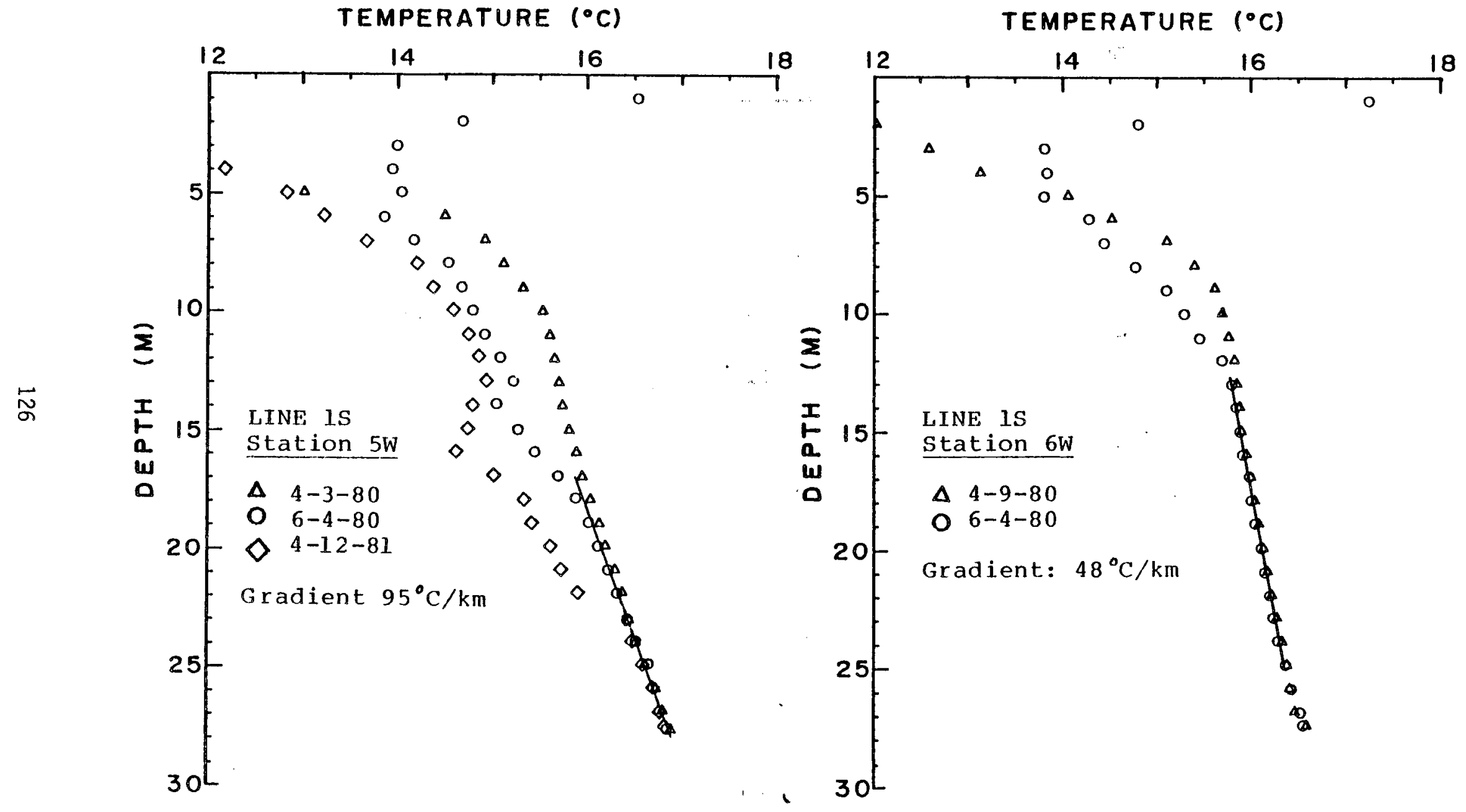




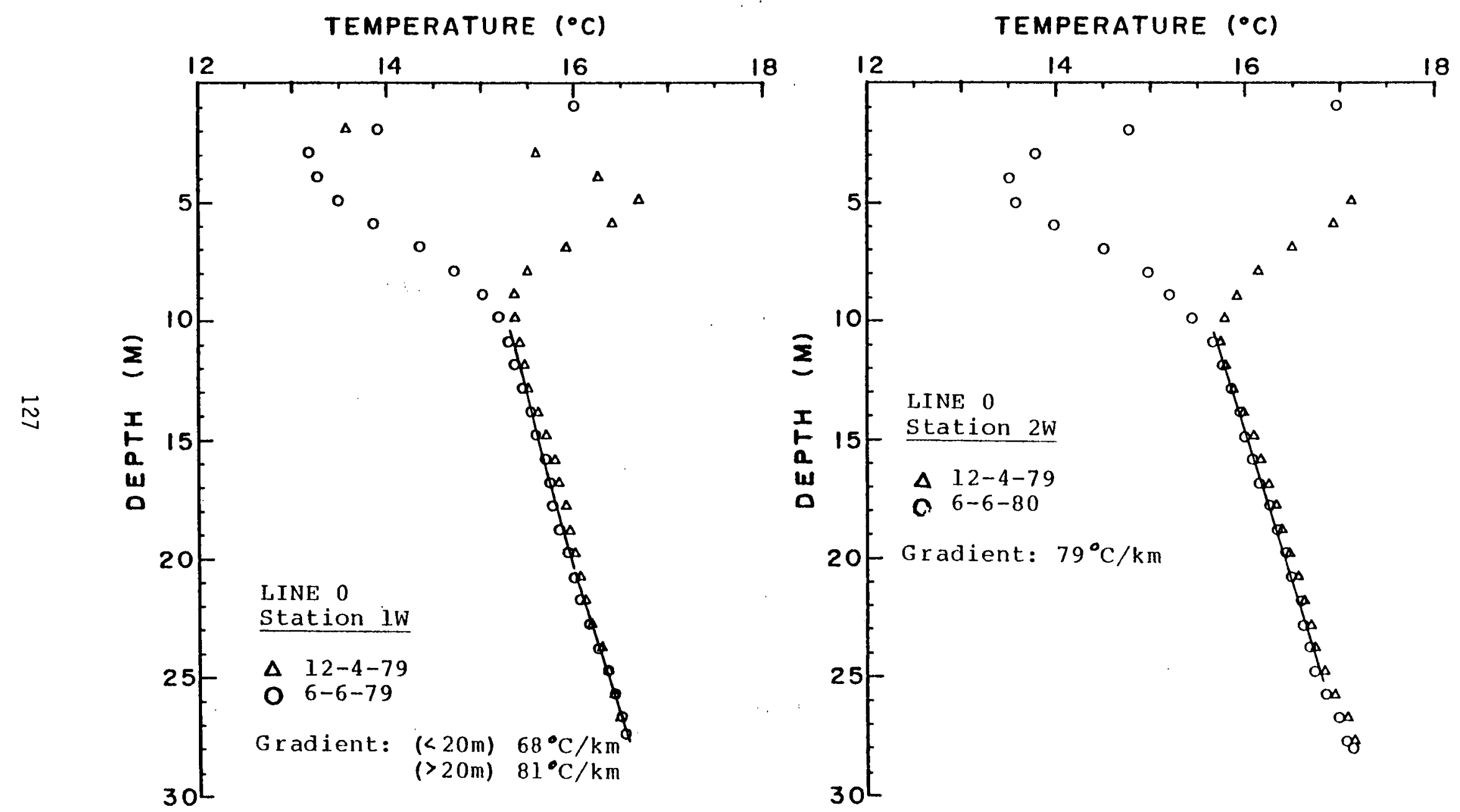




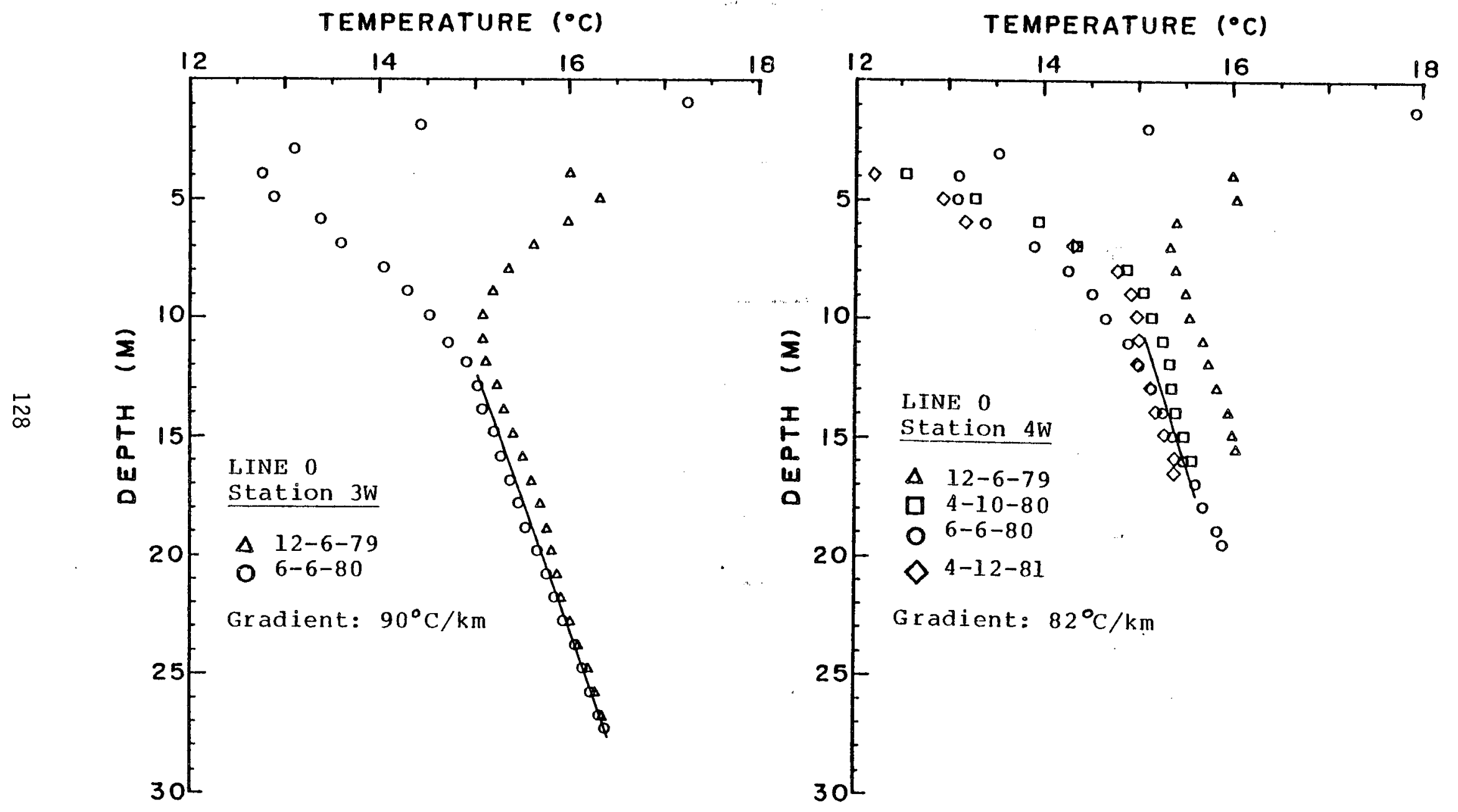


TEMPERATURE $\left({ }^{\circ} \mathrm{C}\right)$

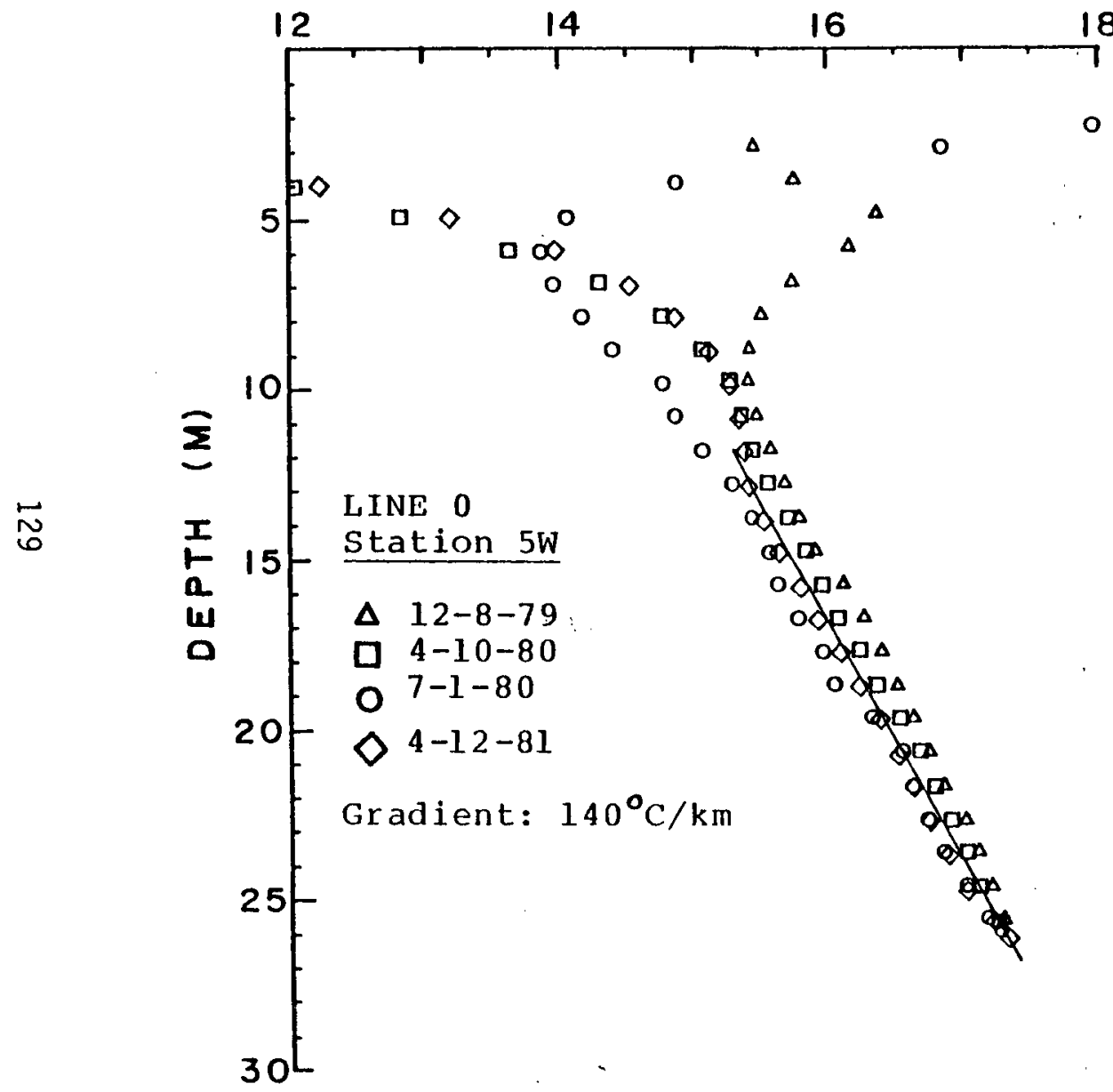

TEMPERATURE $\left({ }^{\circ} \mathrm{C}\right)$

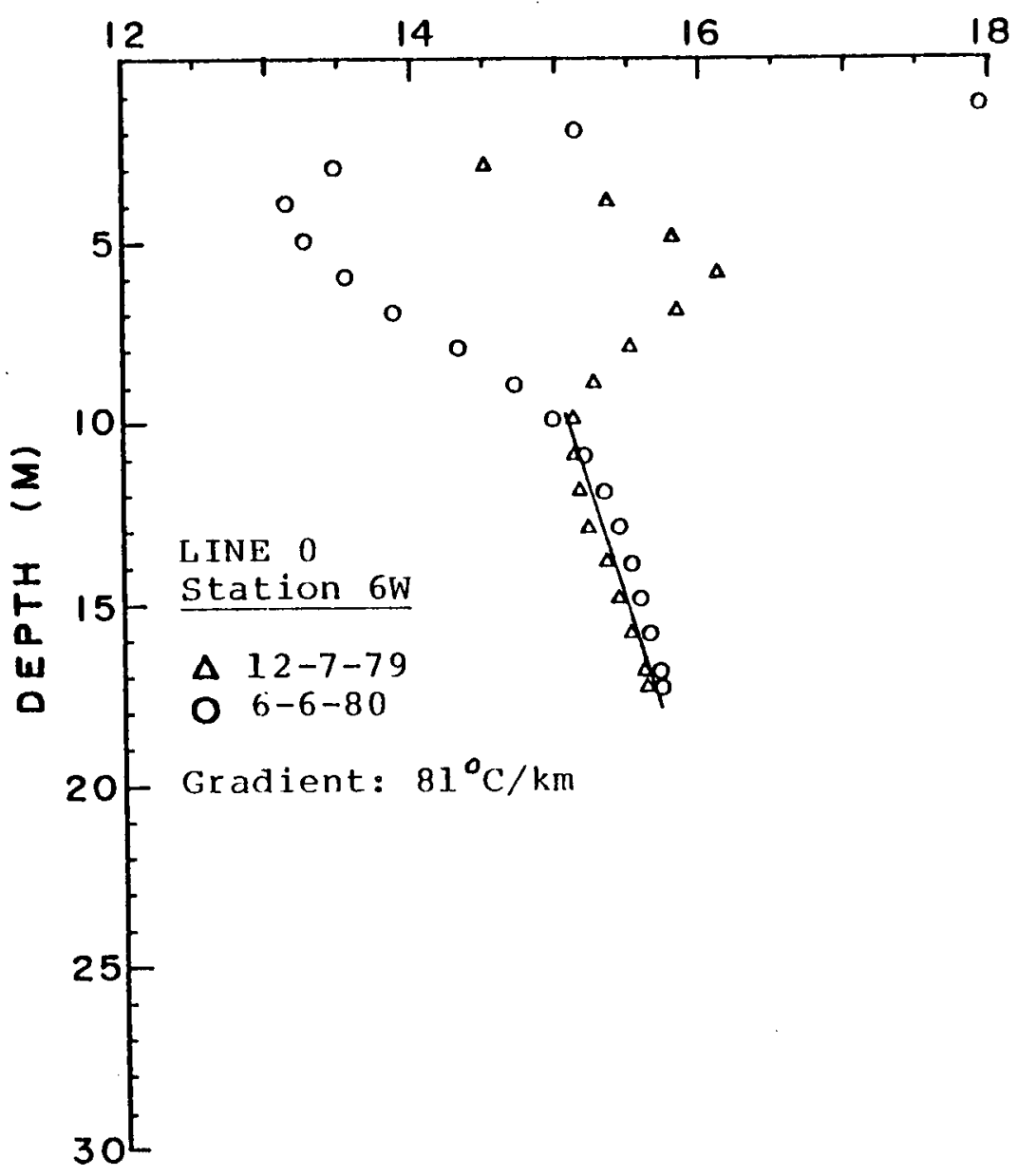




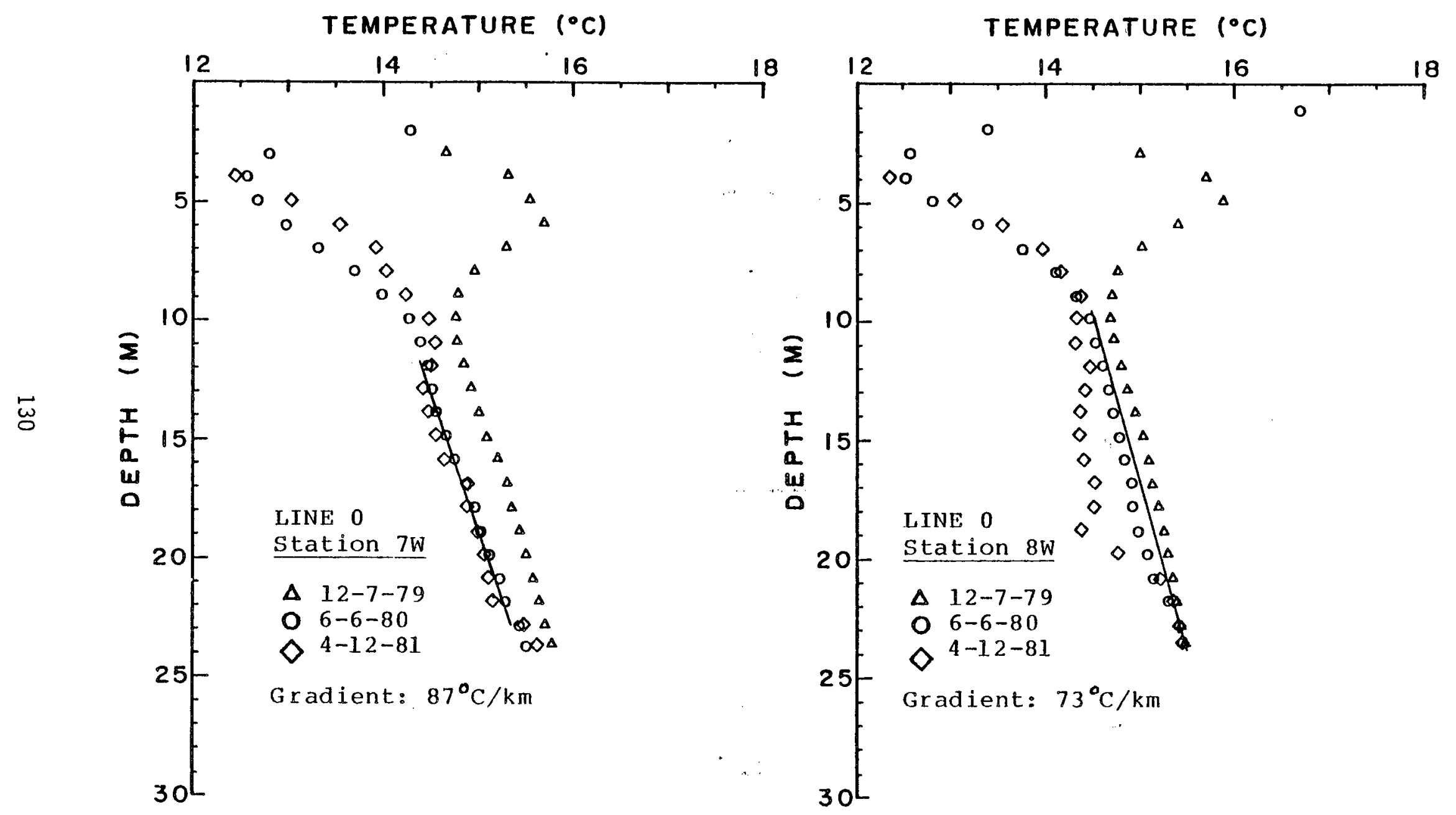




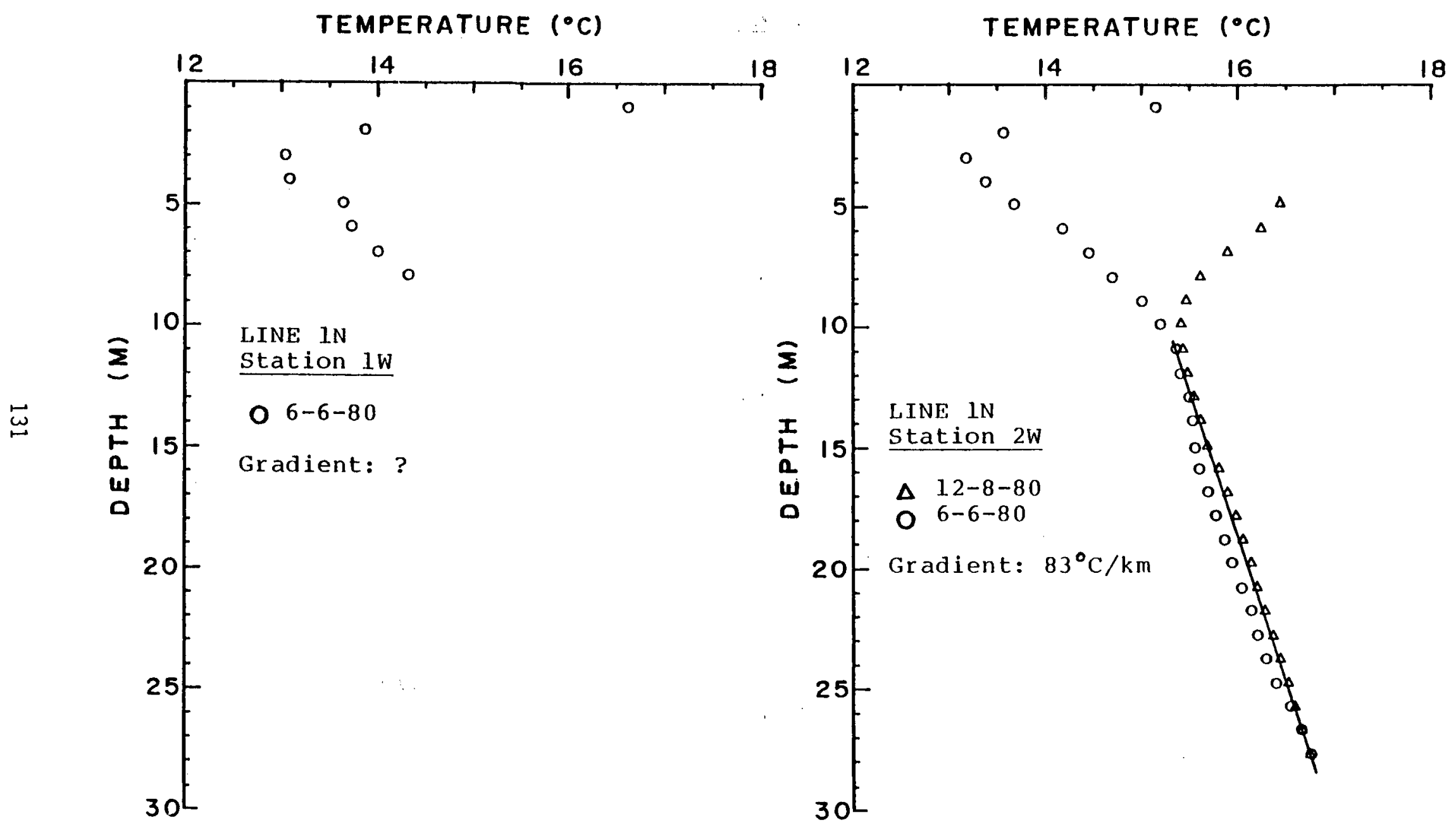


TEMPERATURE $\left({ }^{\circ} \mathrm{C}\right)$

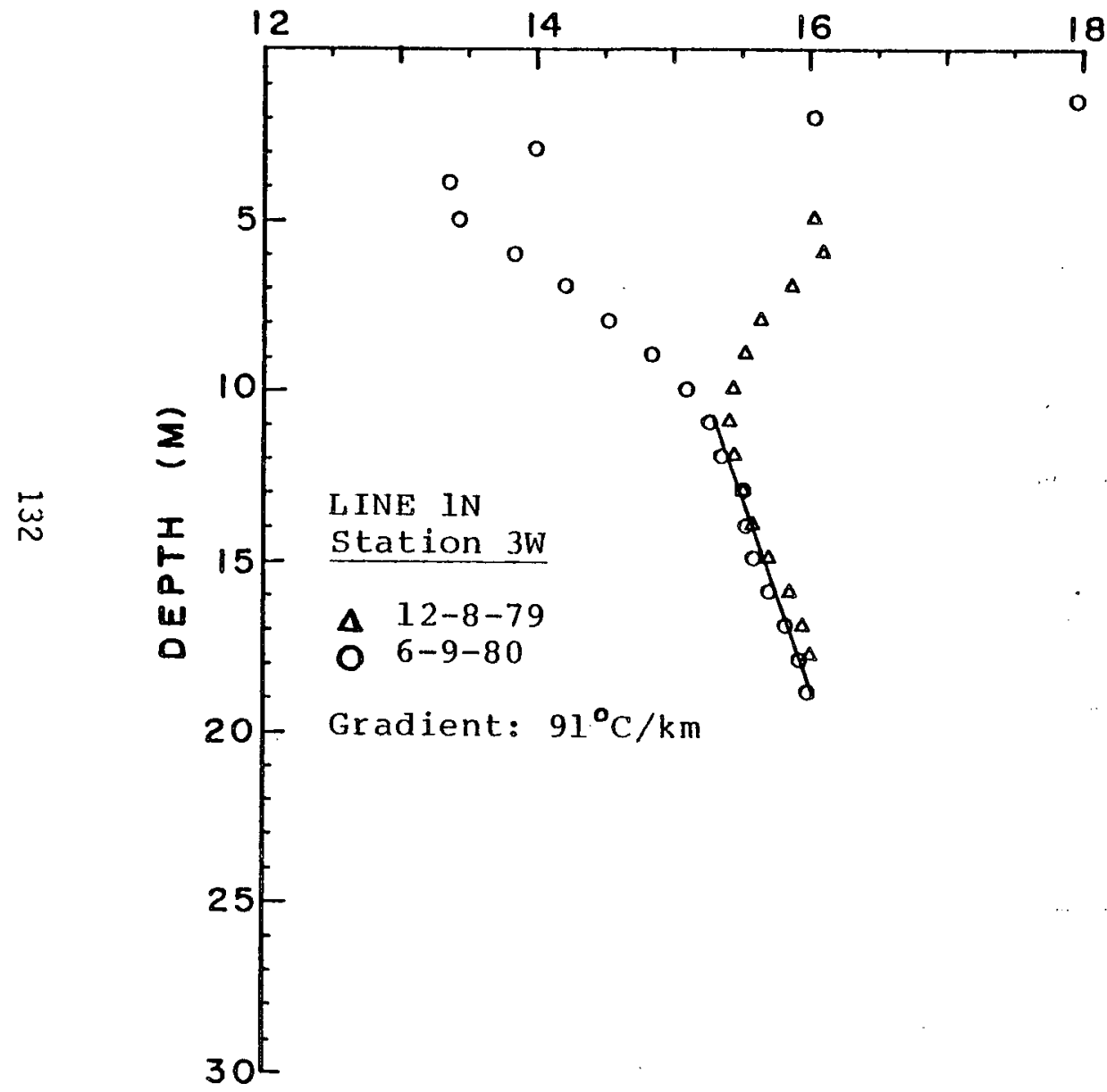

TEMPERATURE $\left({ }^{\circ} \mathrm{C}\right)$

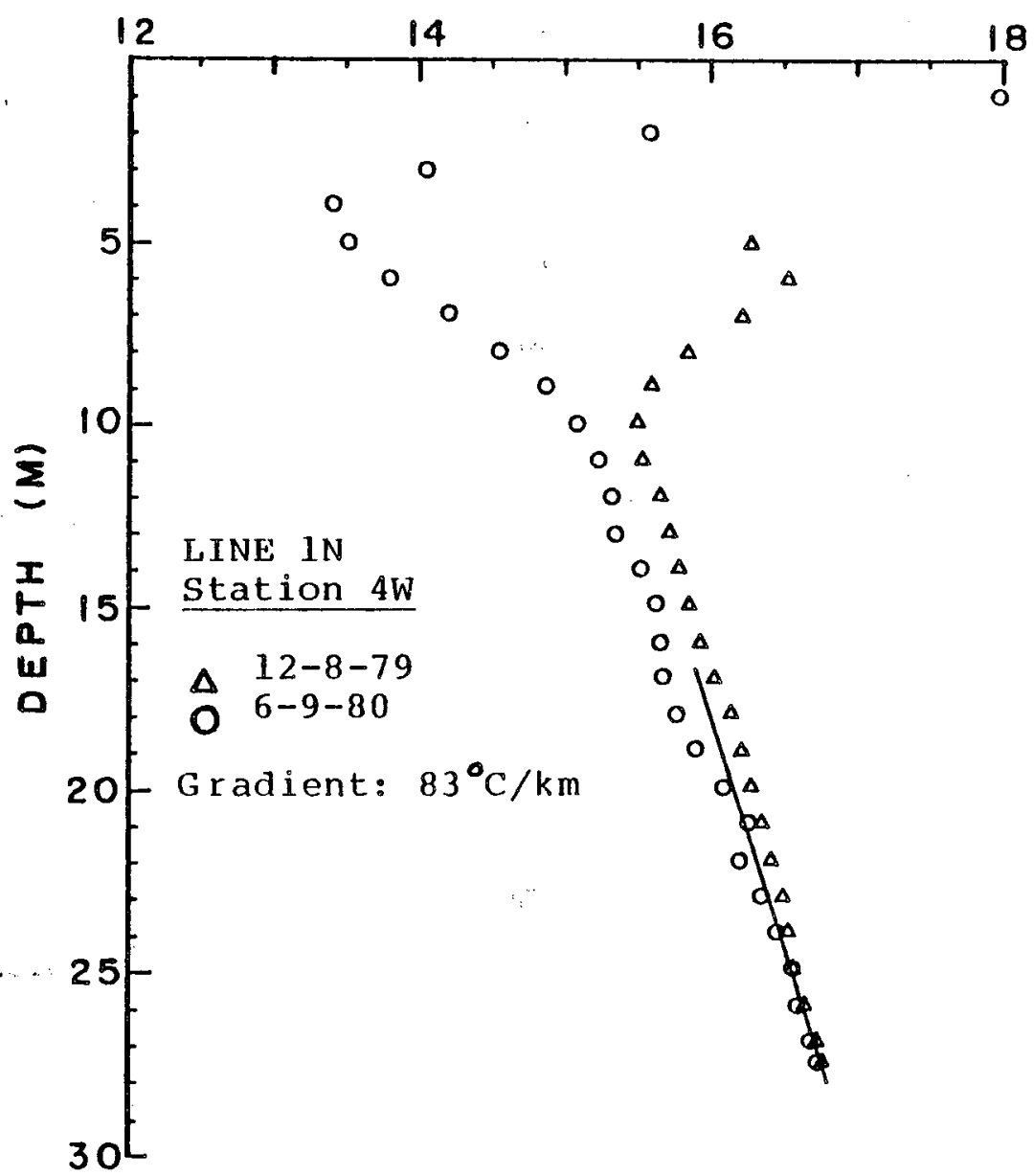




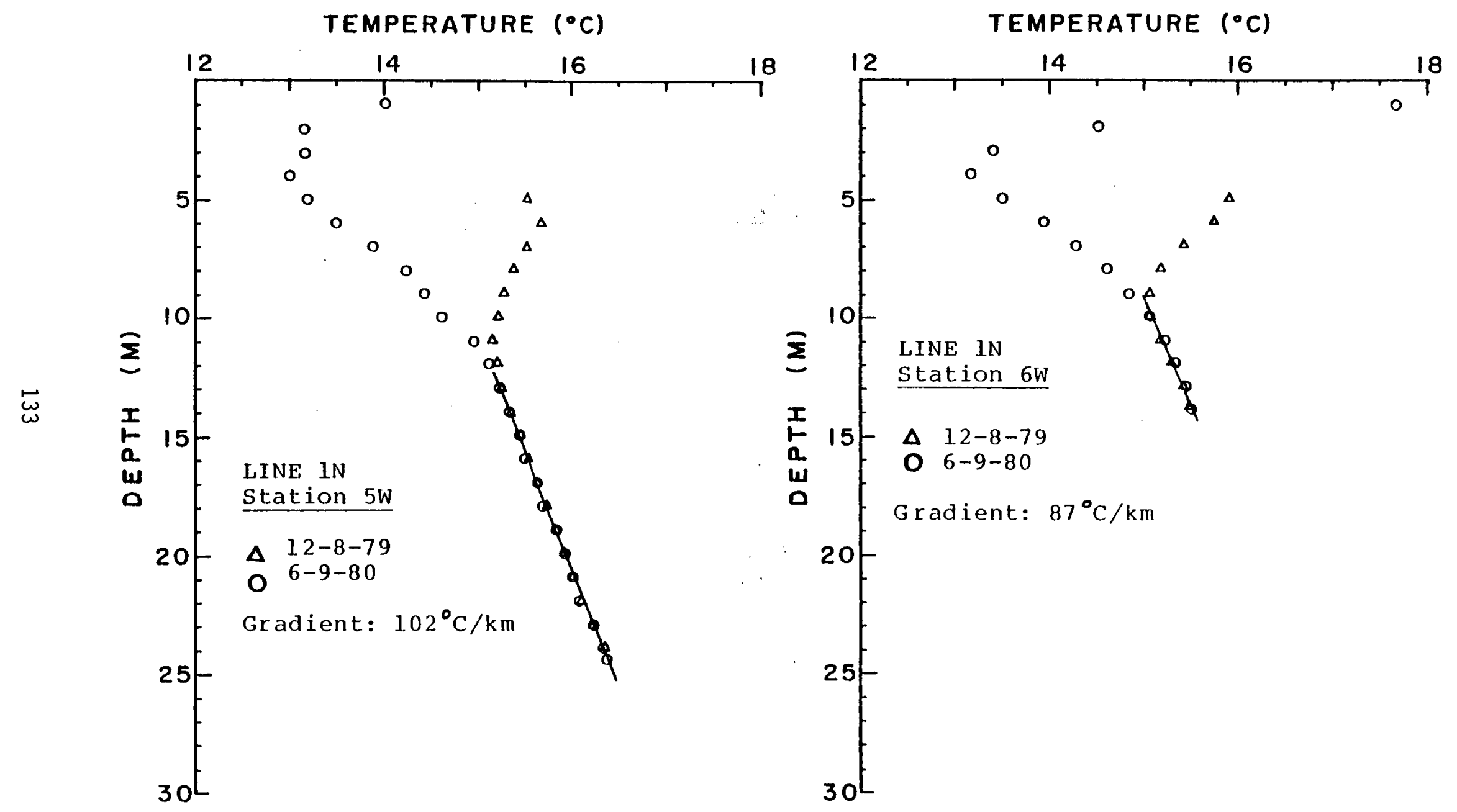



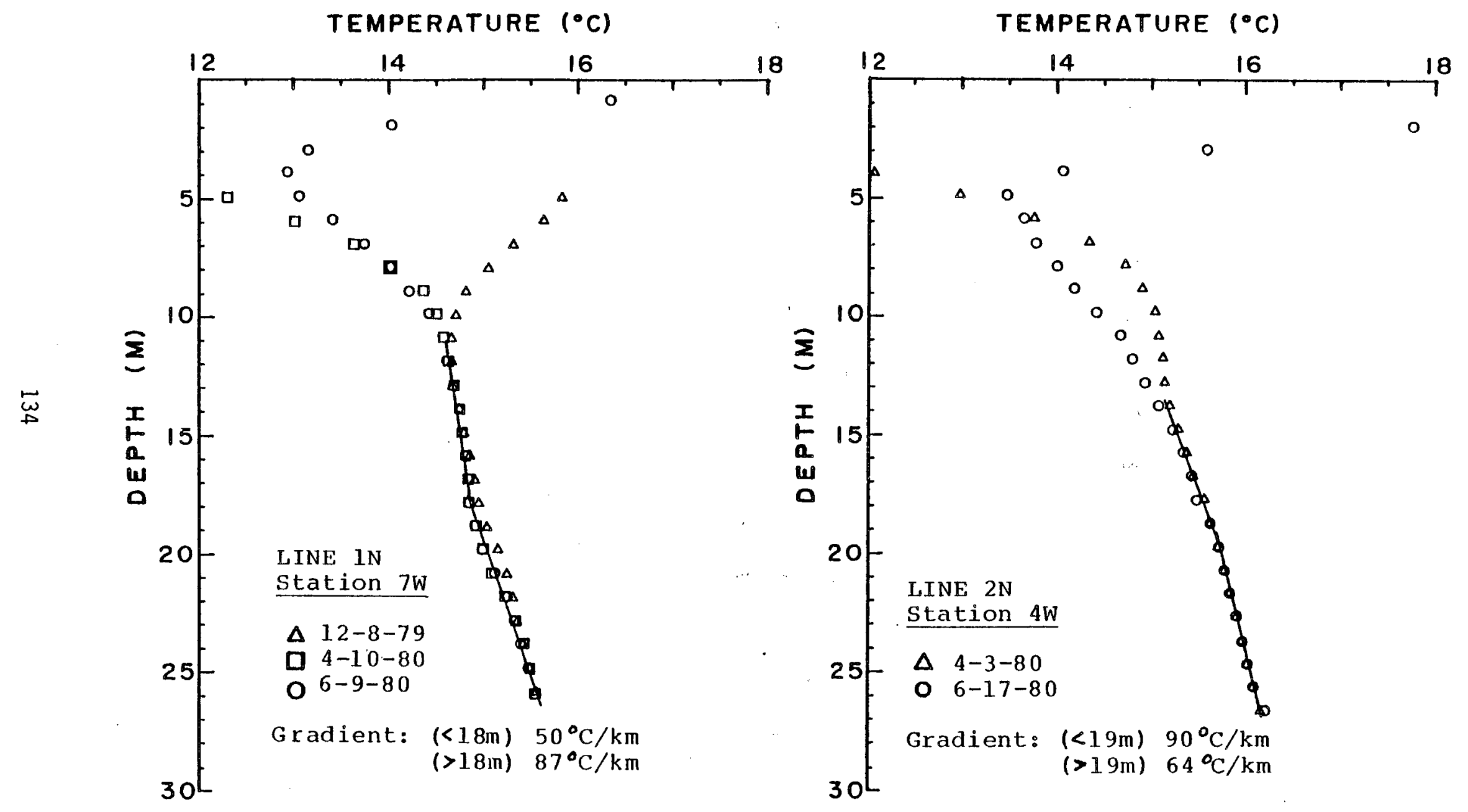


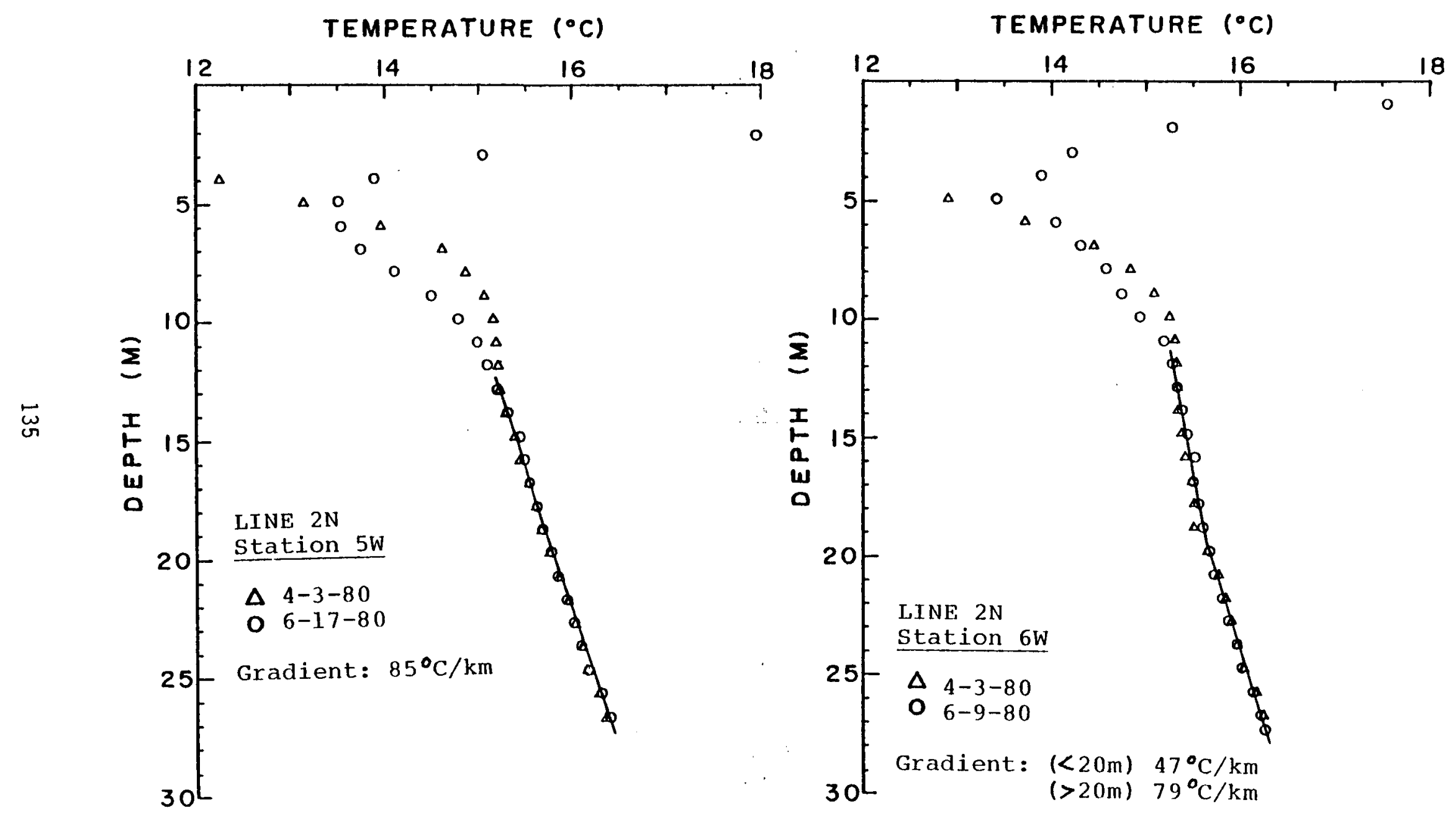



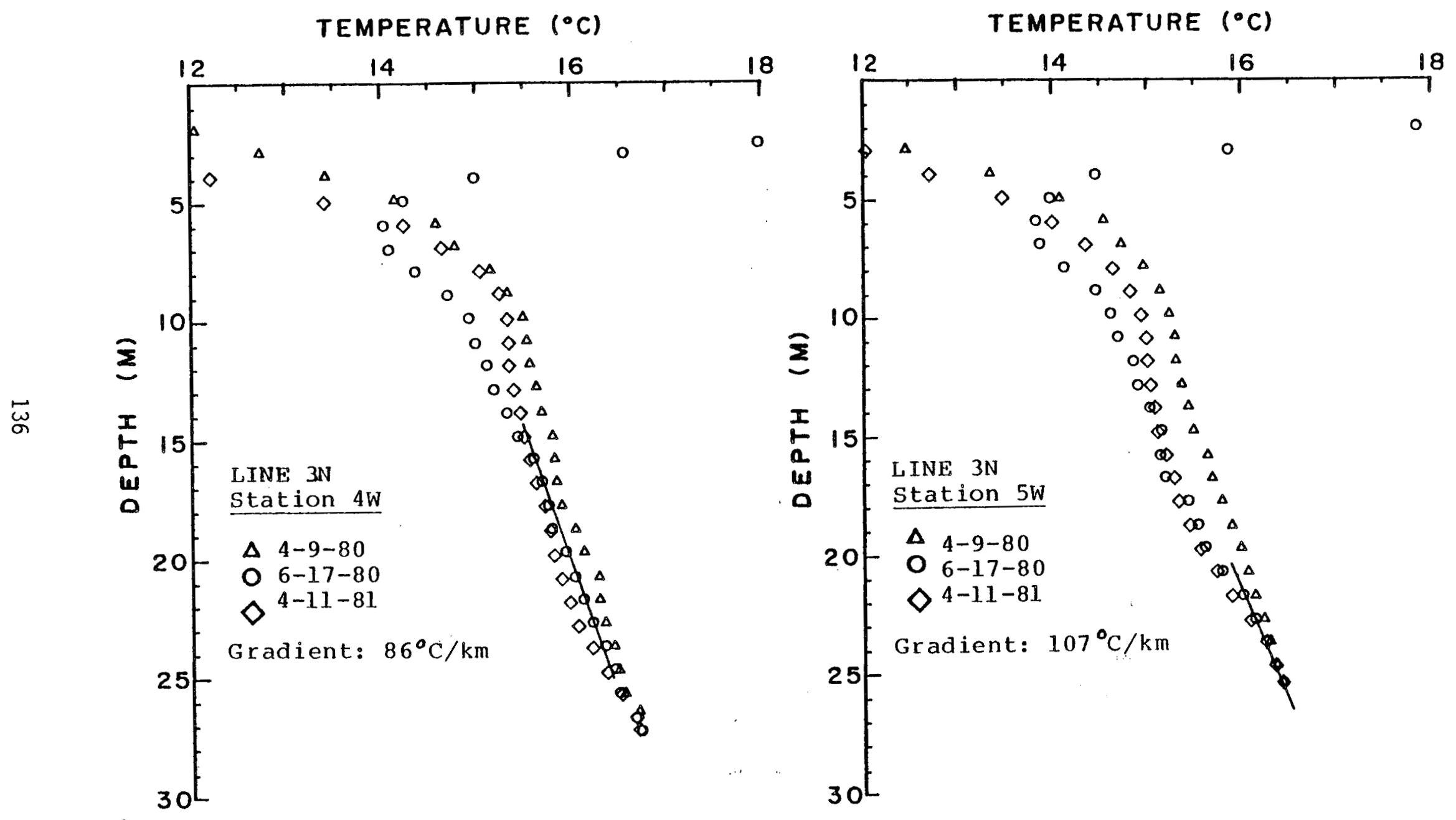

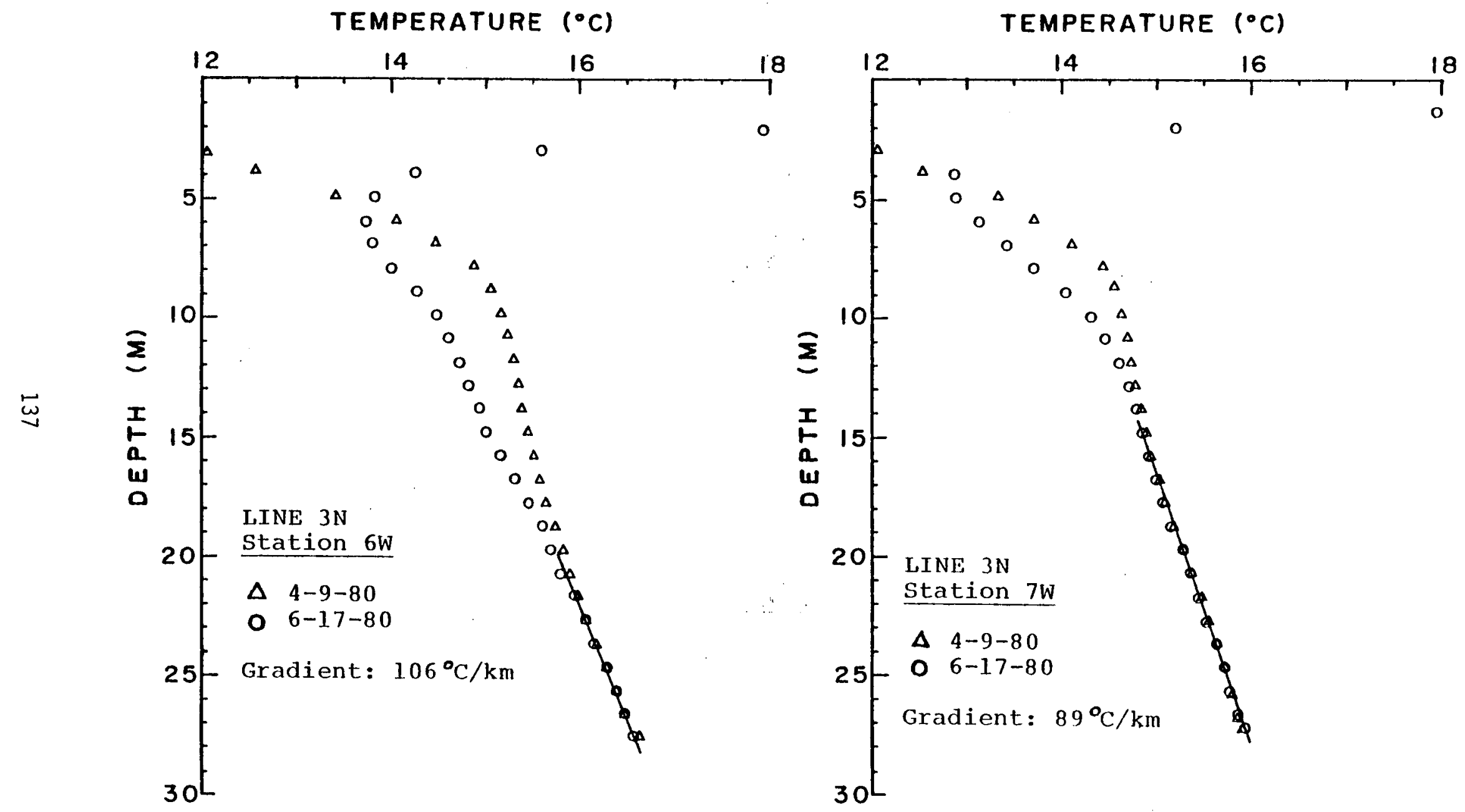
TEMPERATURE $\left({ }^{\circ} \mathrm{C}\right)$

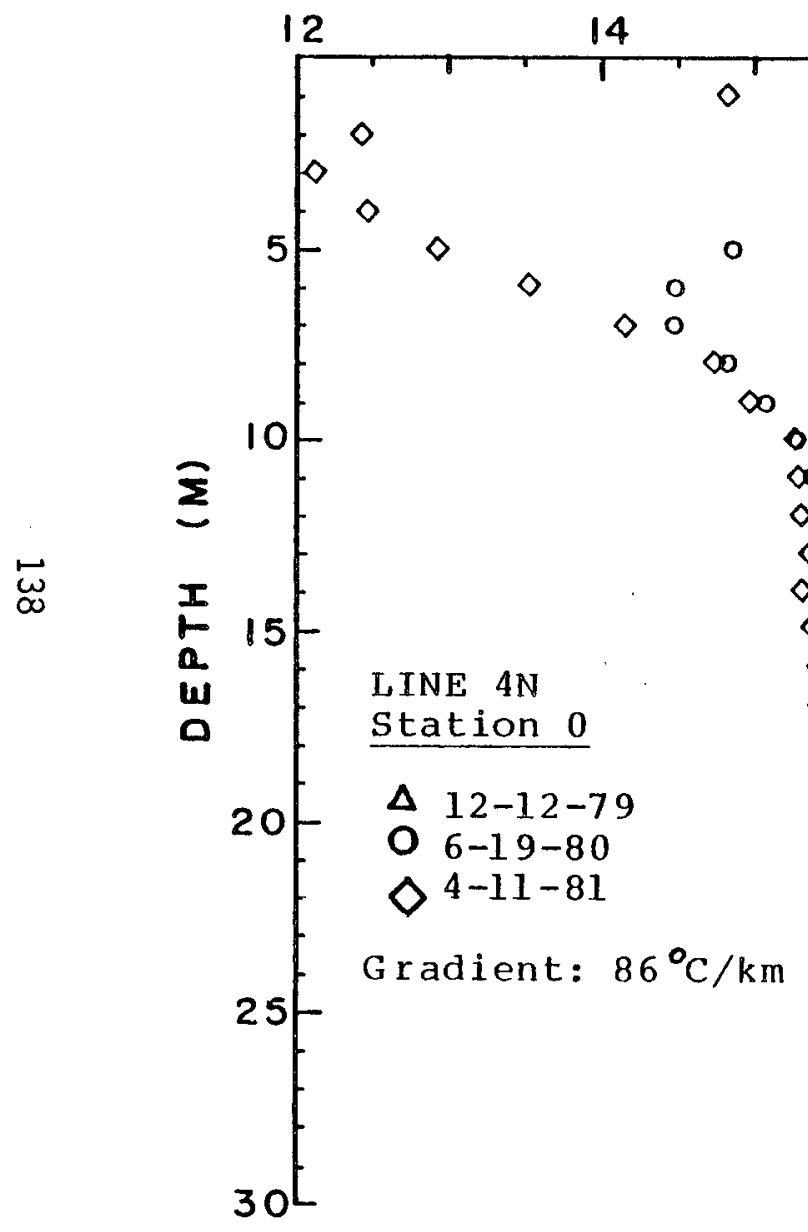

TEMPERATURE $\left({ }^{\circ} \mathrm{C}\right)$

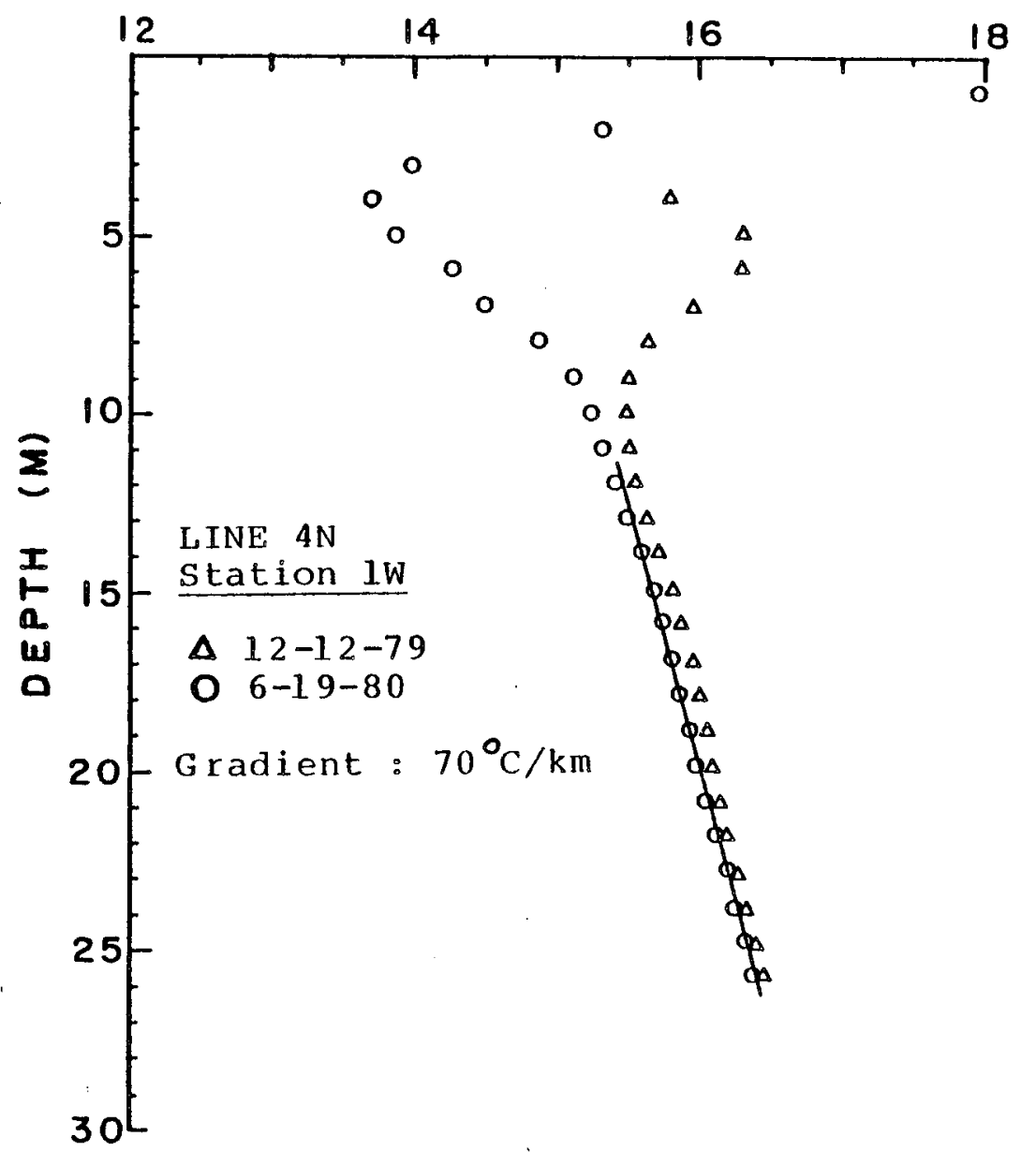




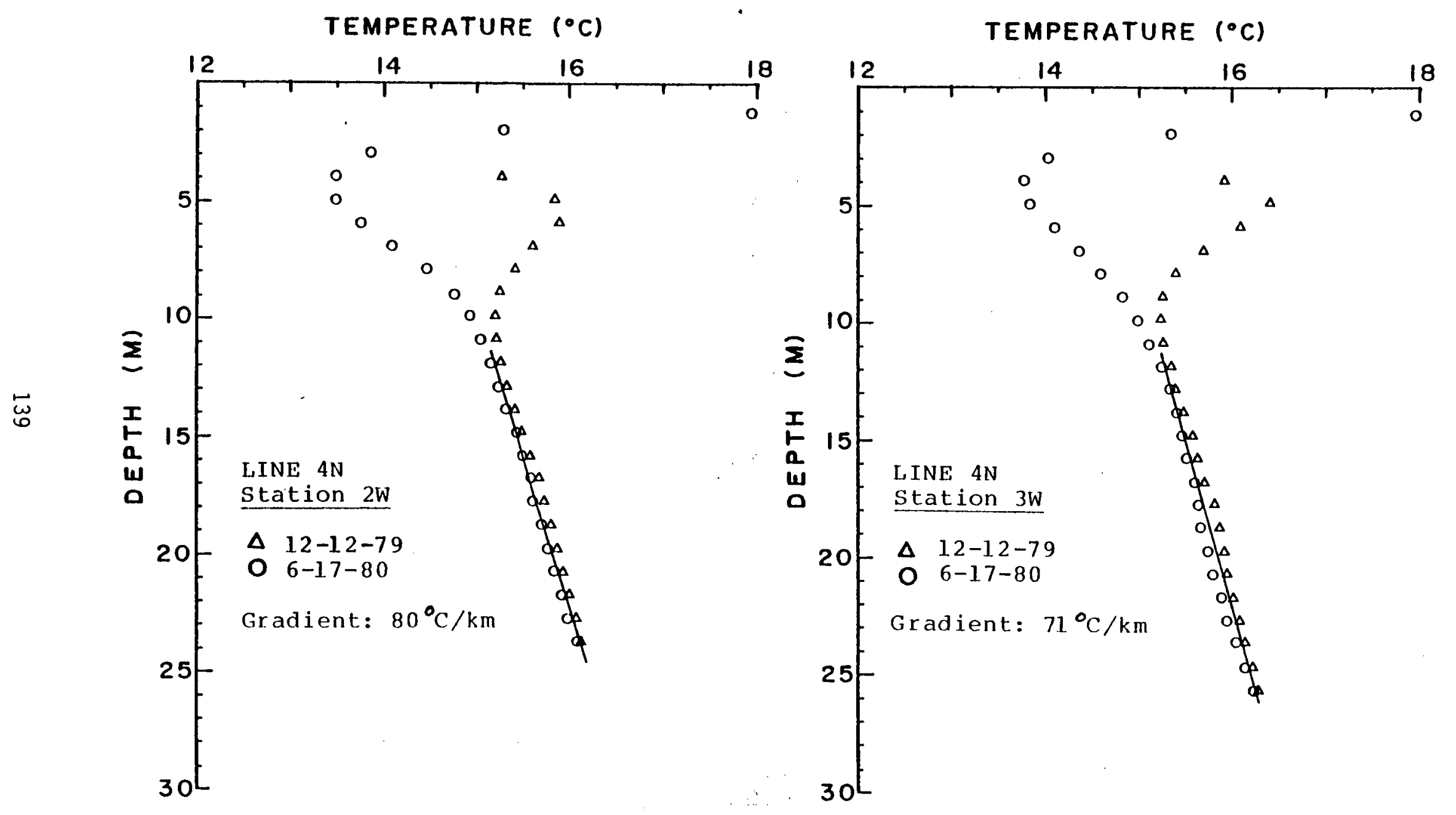



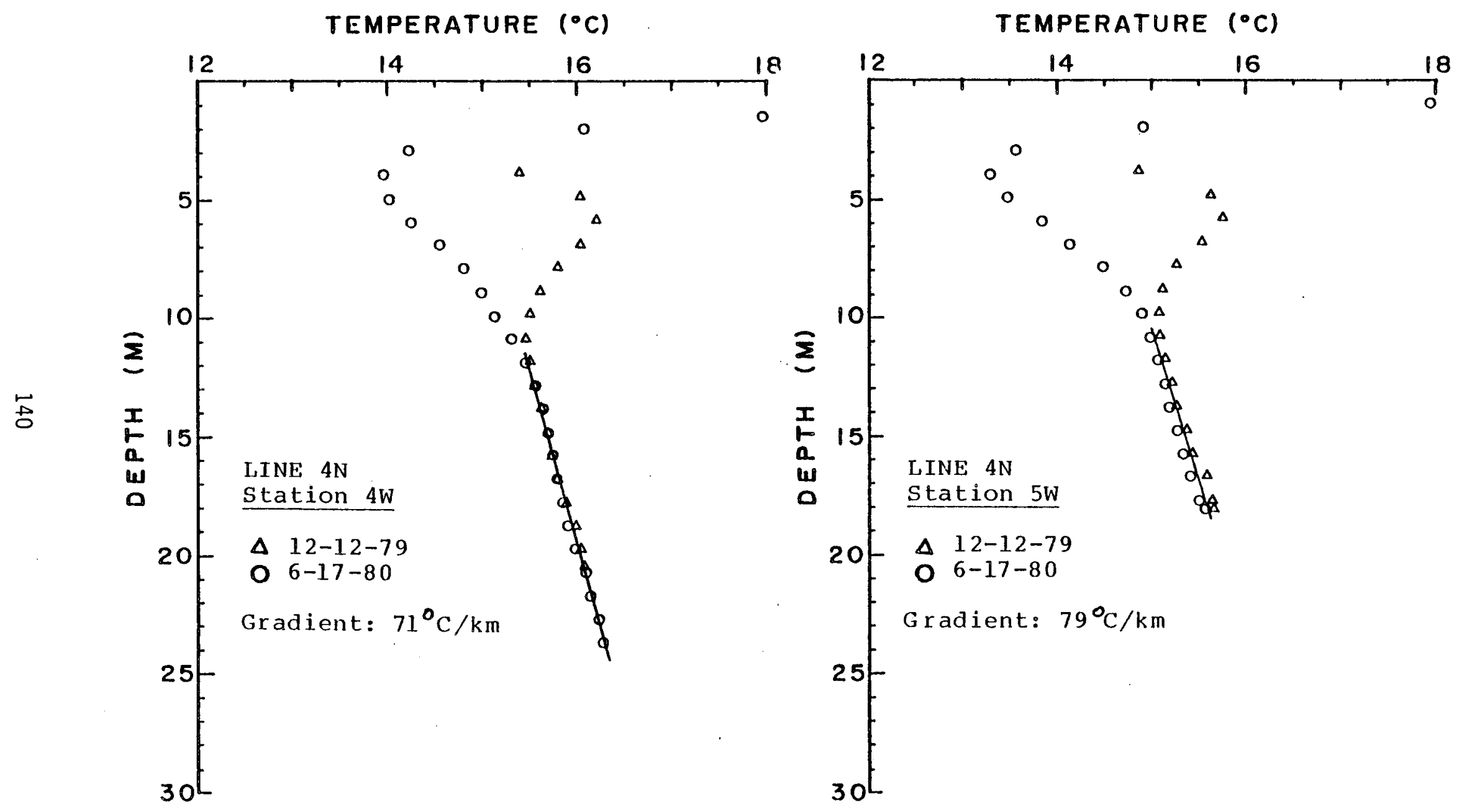
TEMPERATURE $\left({ }^{\circ} \mathrm{C}\right)$

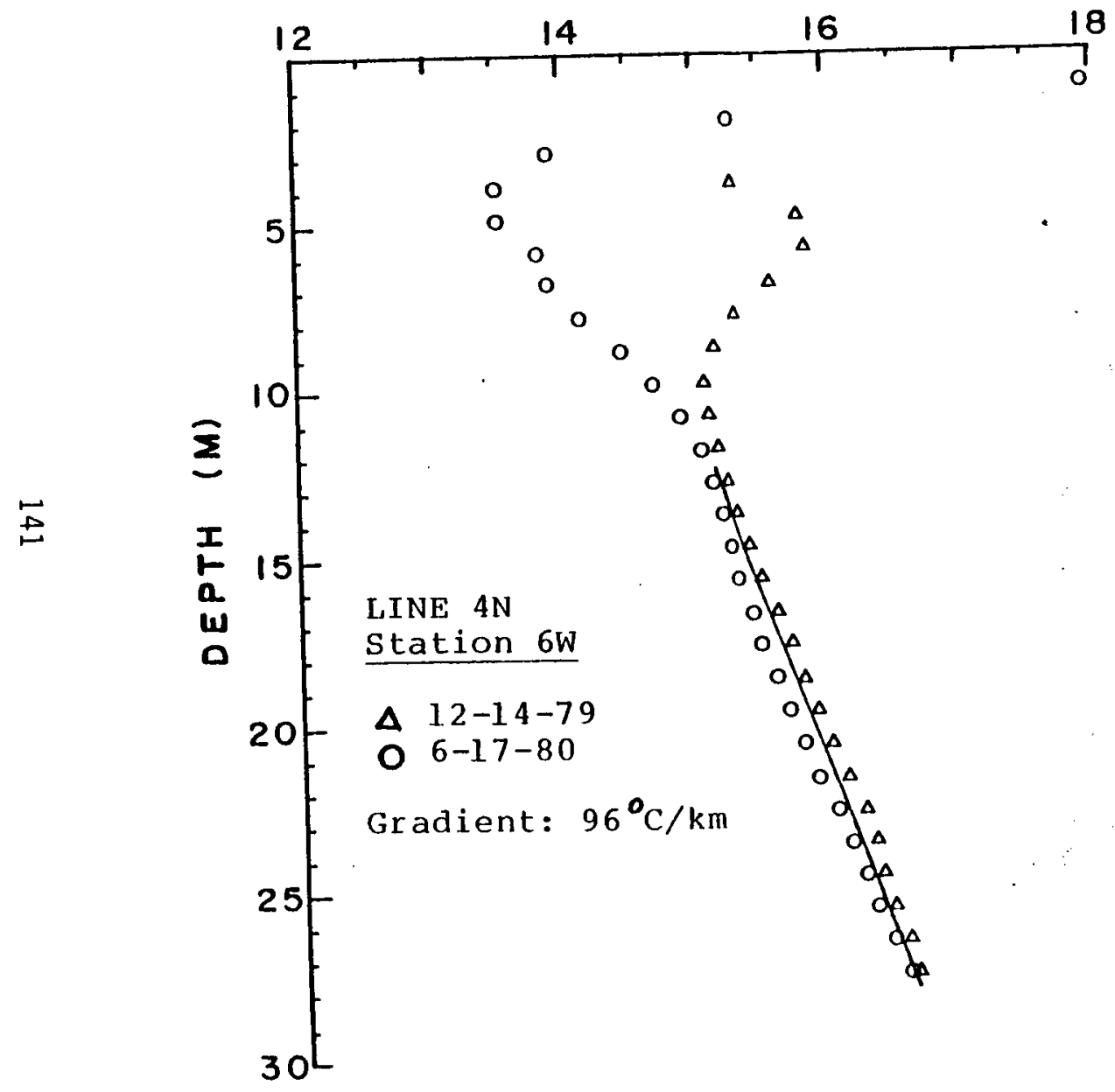

TEMPERATURE $\left({ }^{\circ} \mathrm{C}\right)$

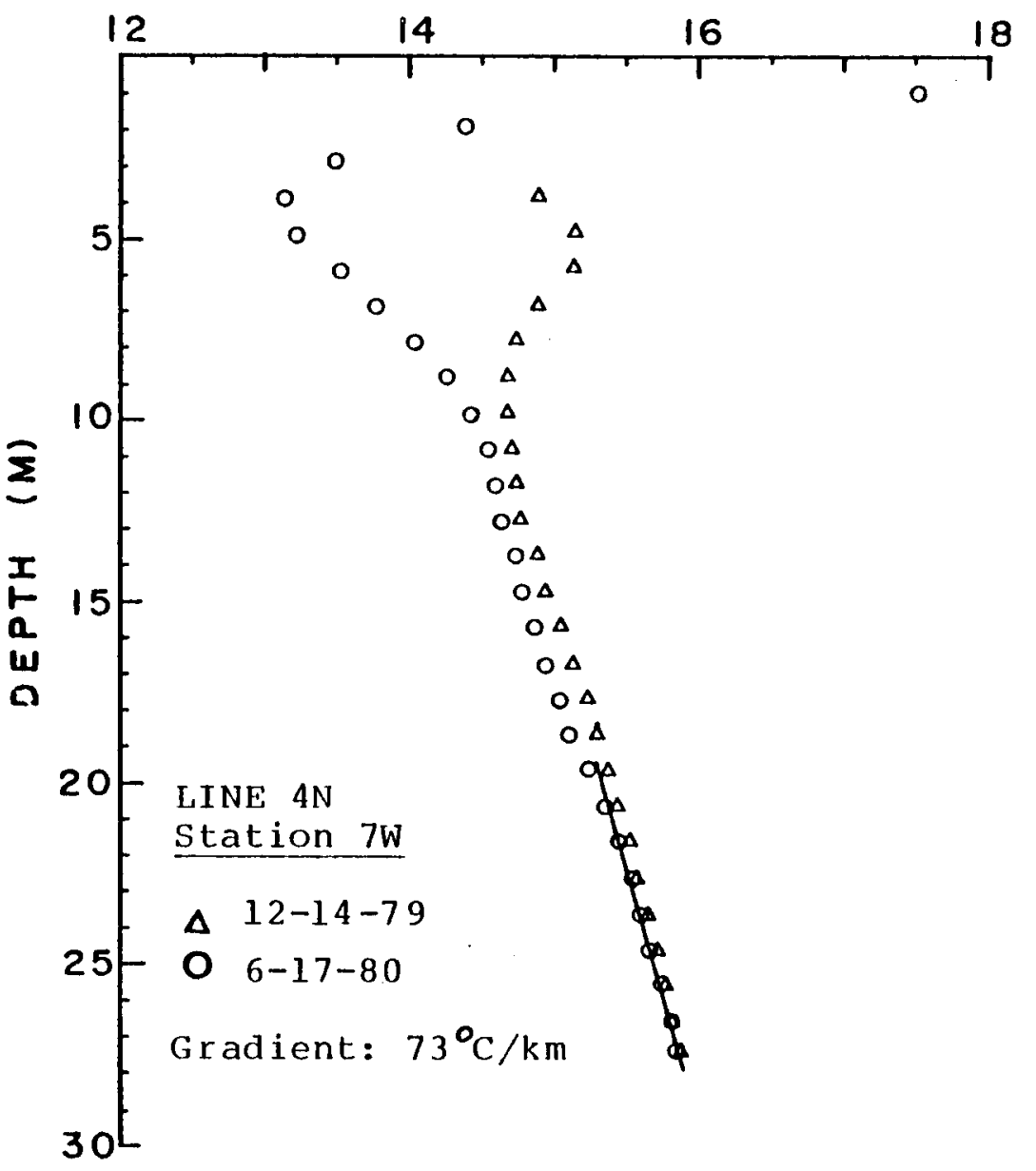




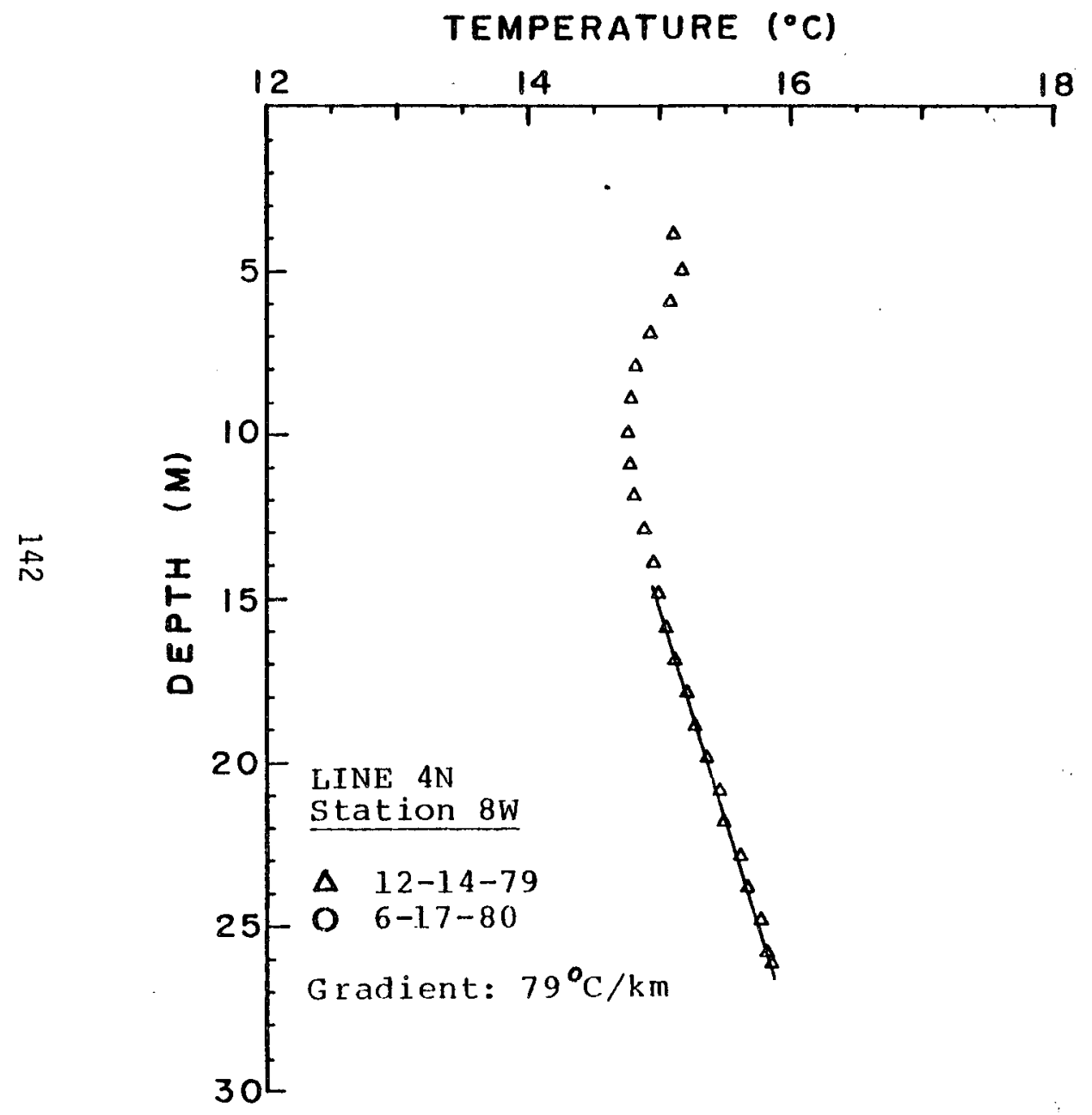


TEMPERATURE $\left({ }^{\circ} \mathrm{C}\right)$

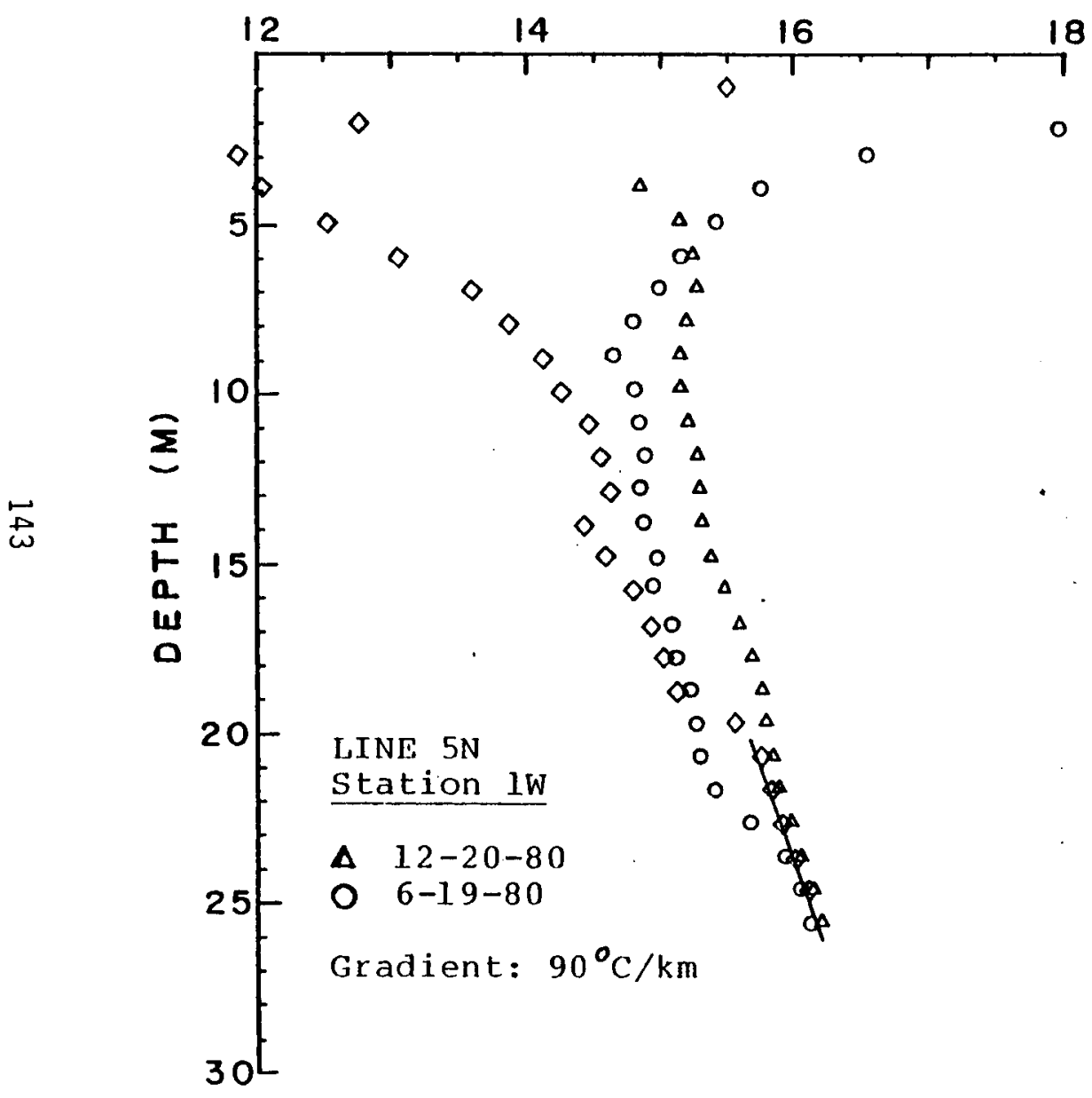

TEMPERATURE $\left({ }^{\circ} \mathrm{C}\right)$

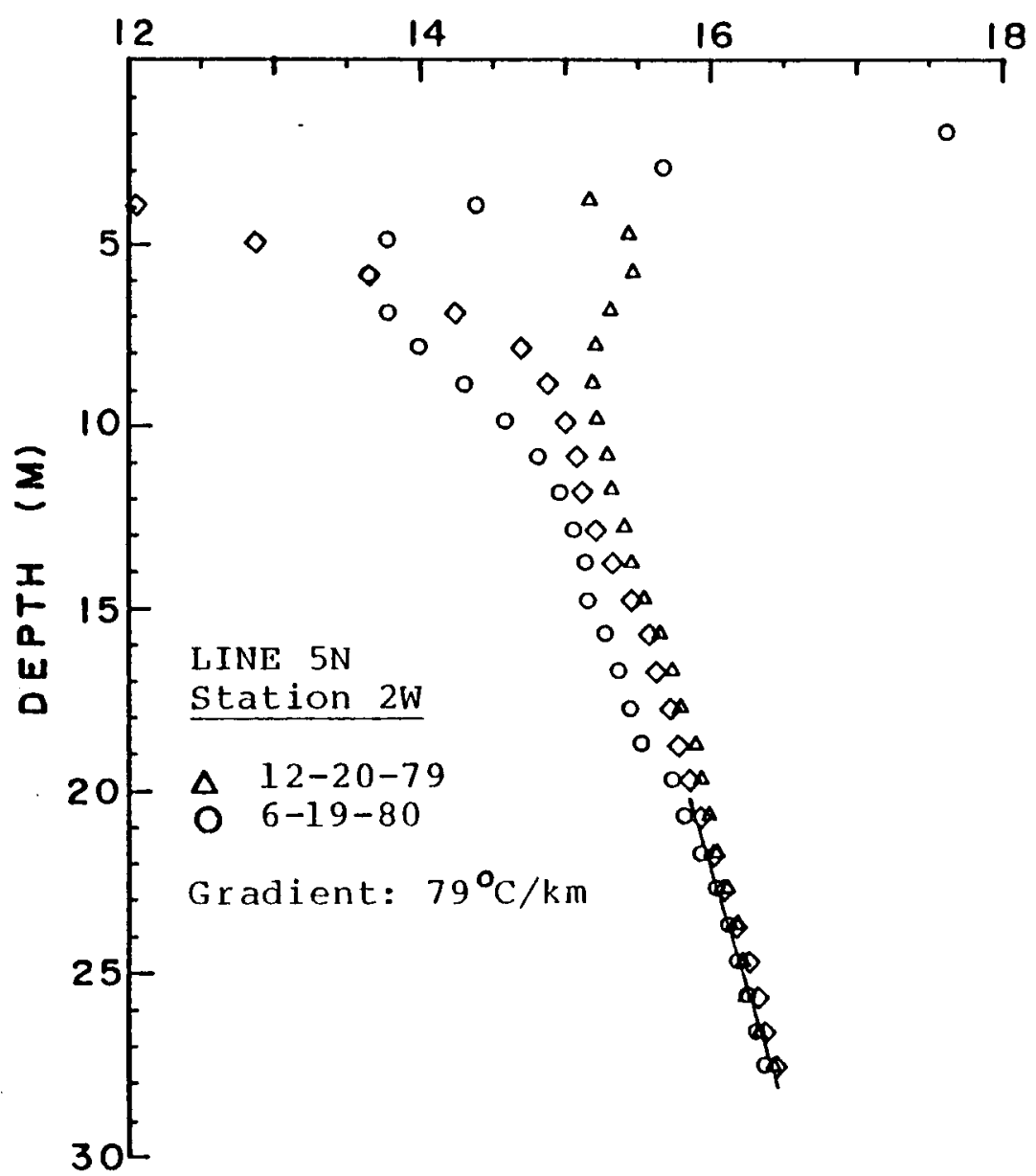



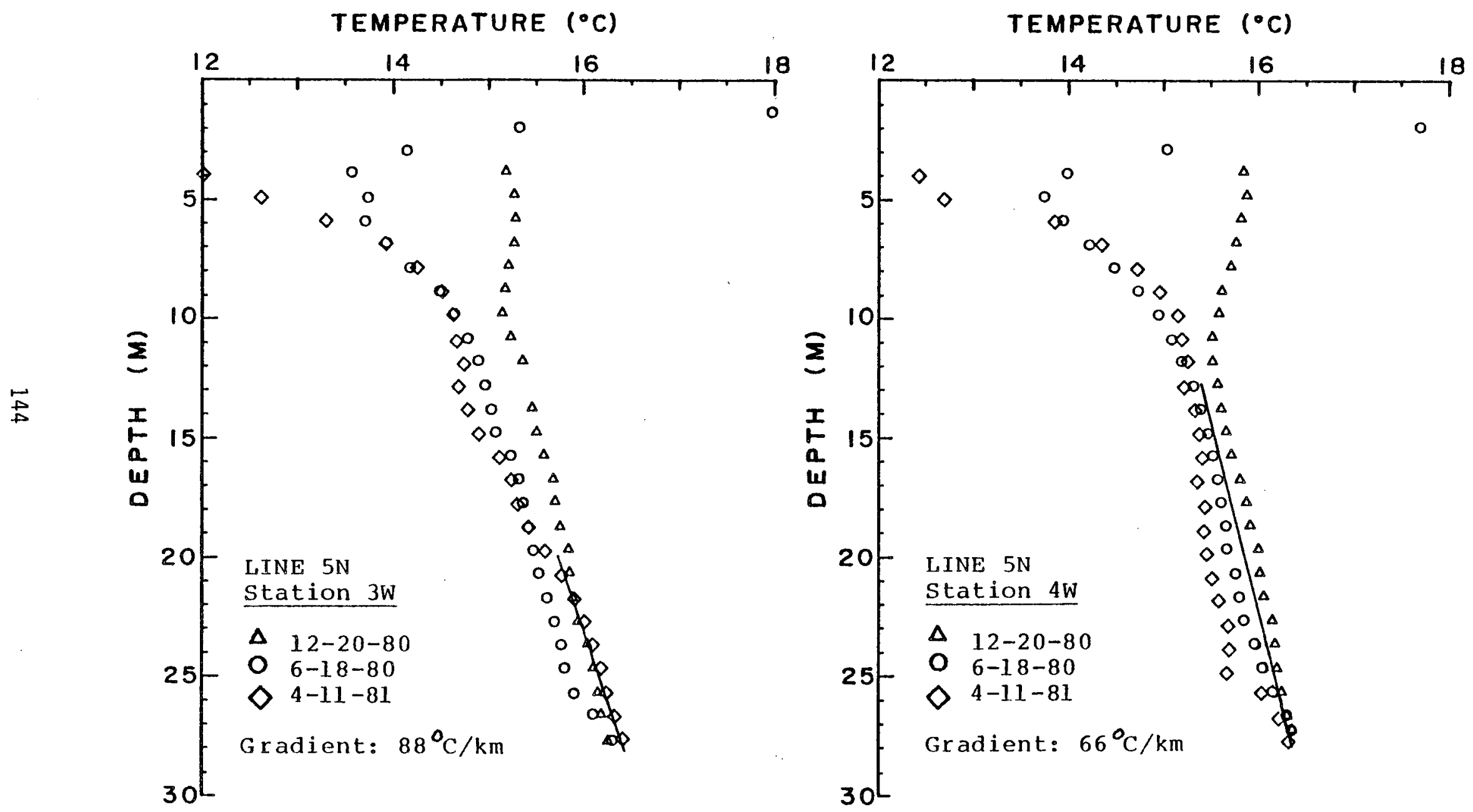
TEMPERATURE $\left({ }^{\circ} \mathrm{C}\right)$

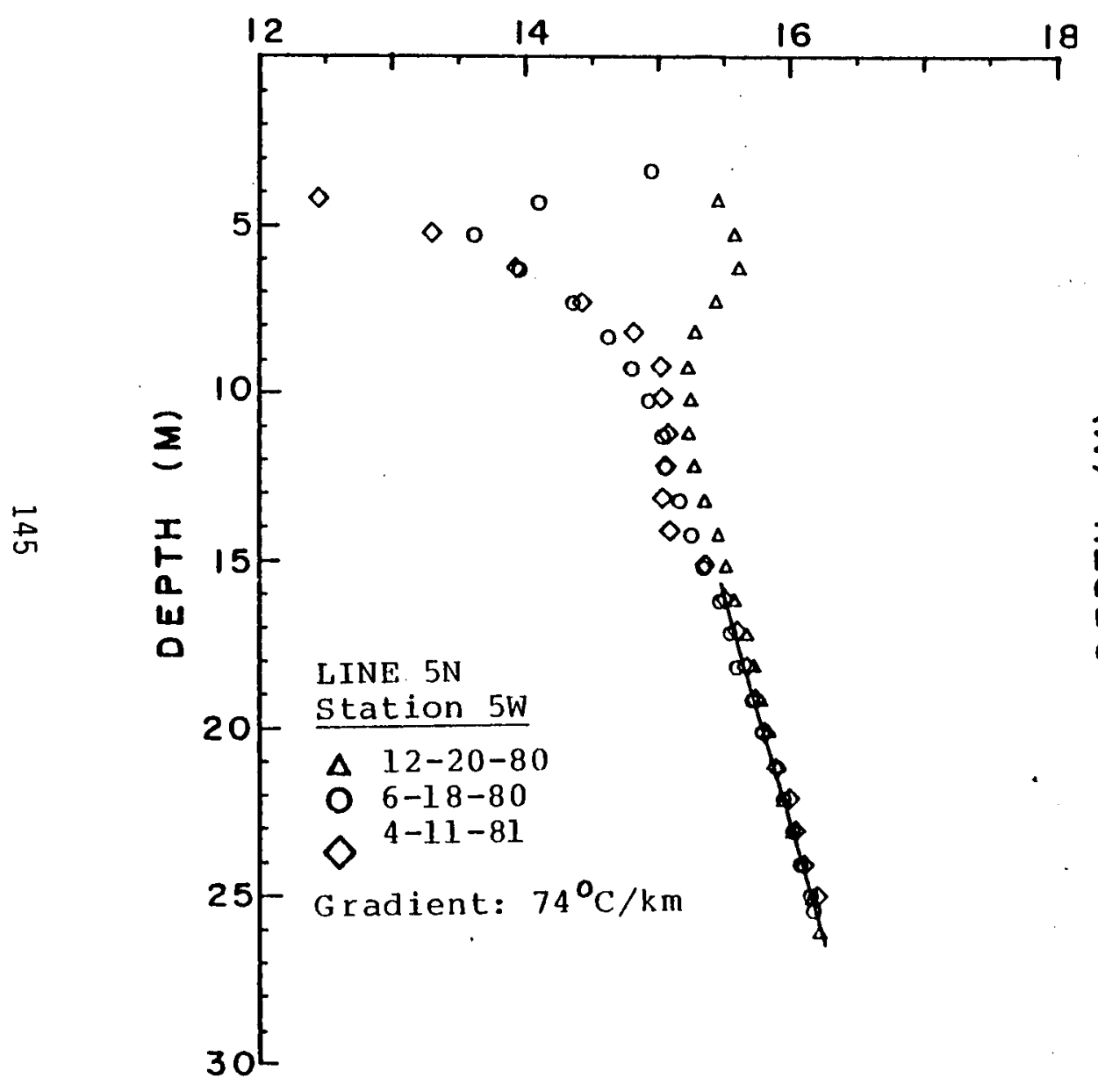

TEMPERATURE $\left({ }^{\circ} \mathrm{C}\right)$

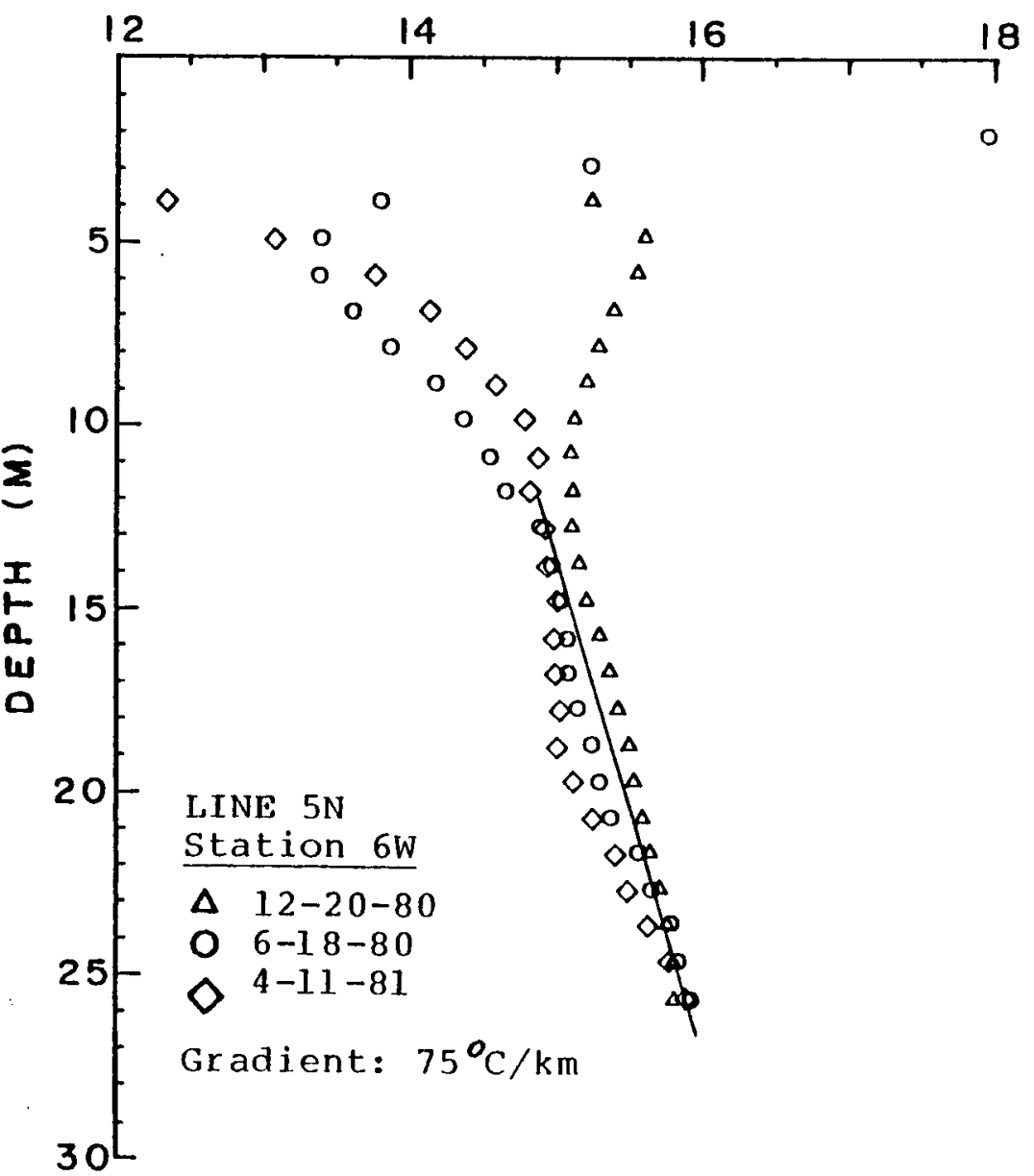



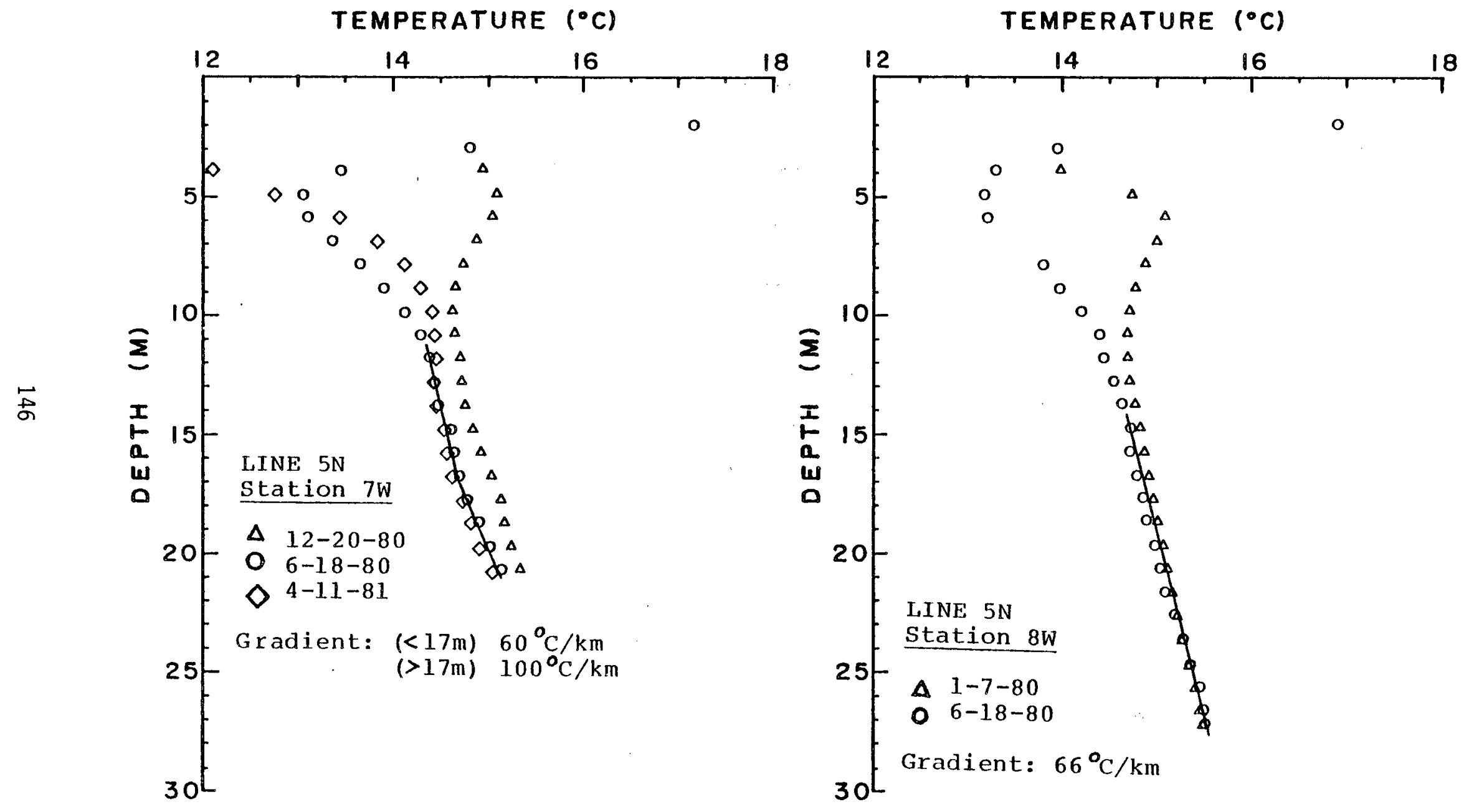
TEMPERATURE $\left({ }^{\circ} \mathrm{C}\right)$

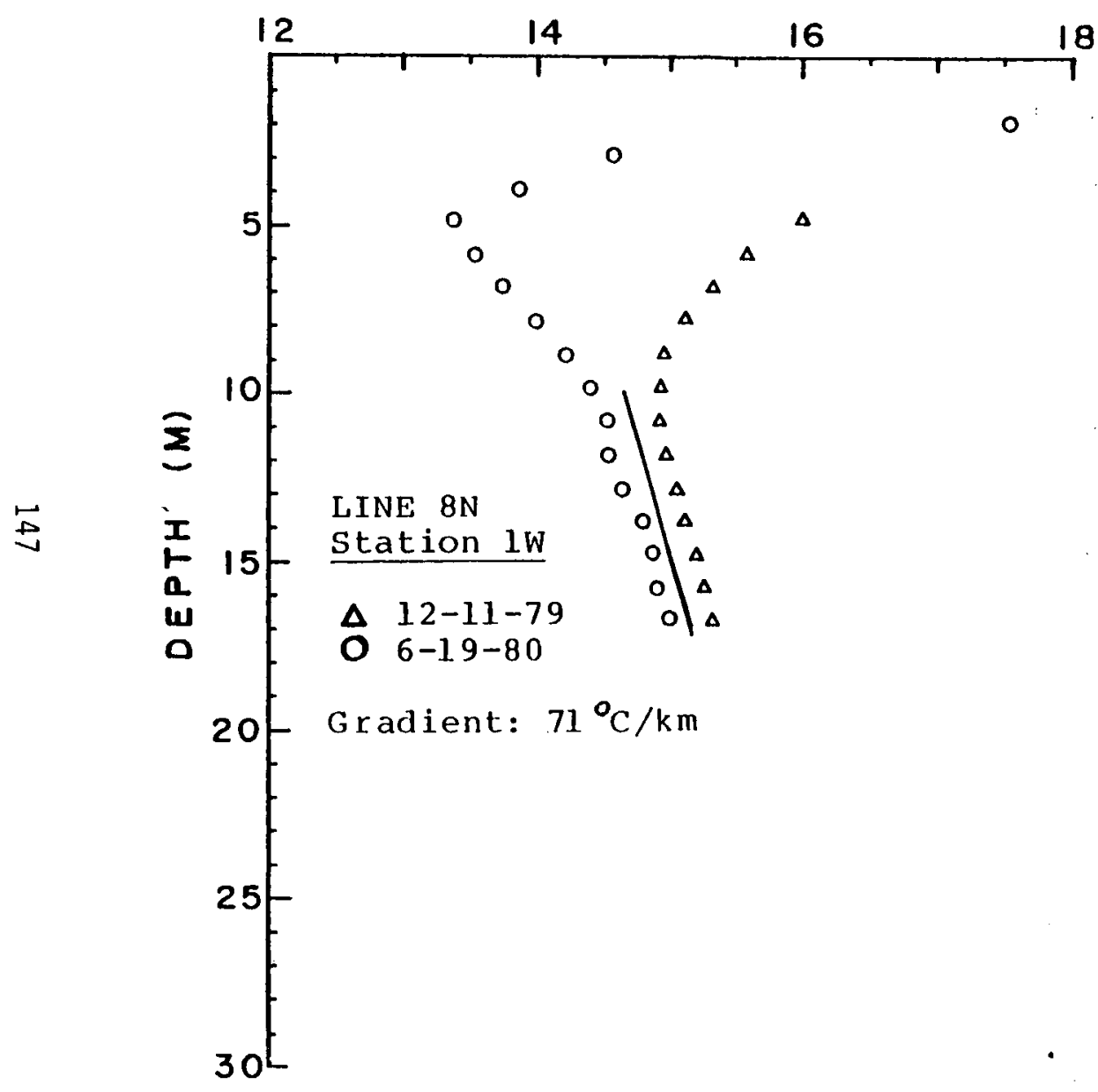

TEMPERATURE $\left({ }^{\circ} \mathrm{C}\right)$

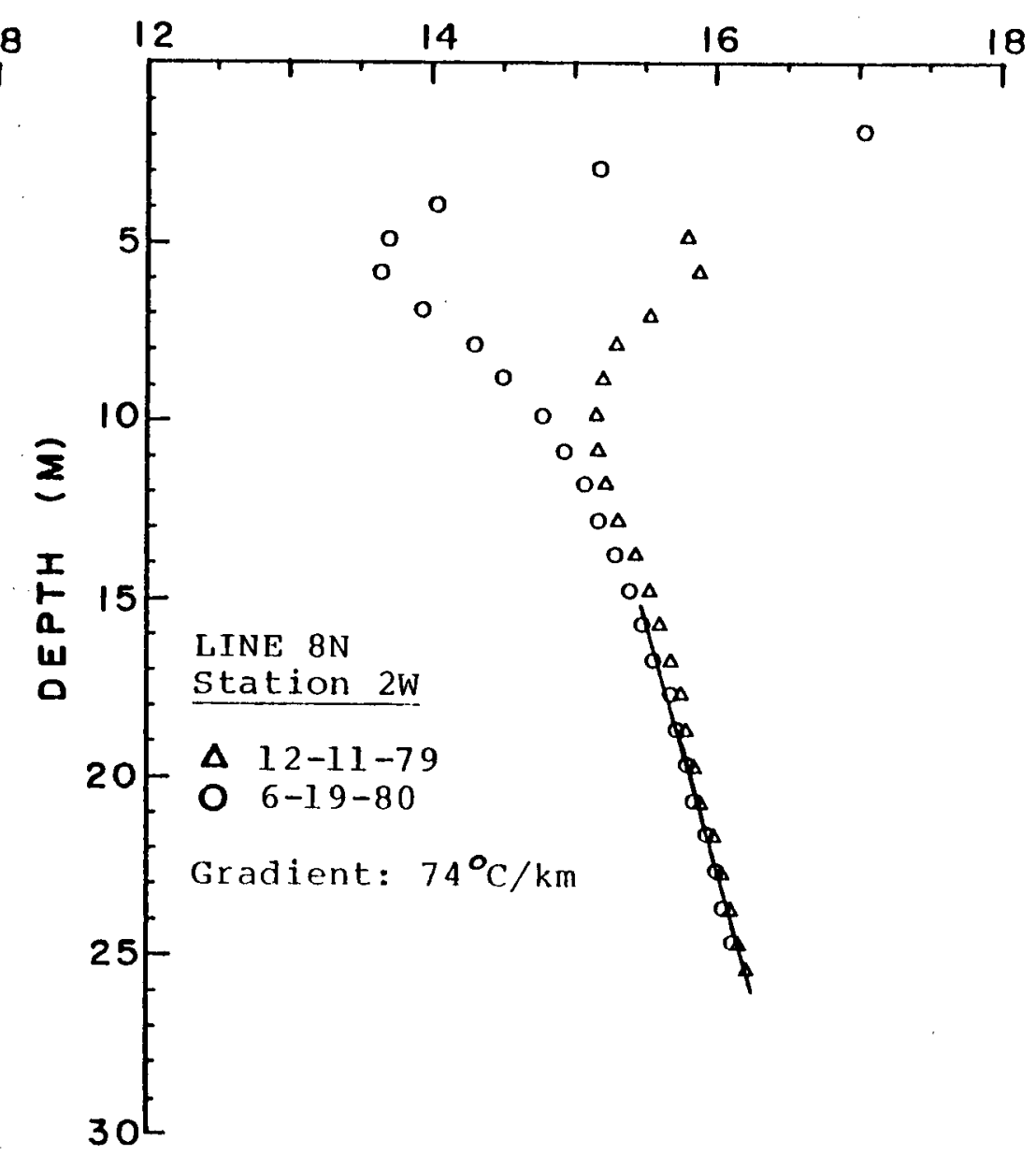




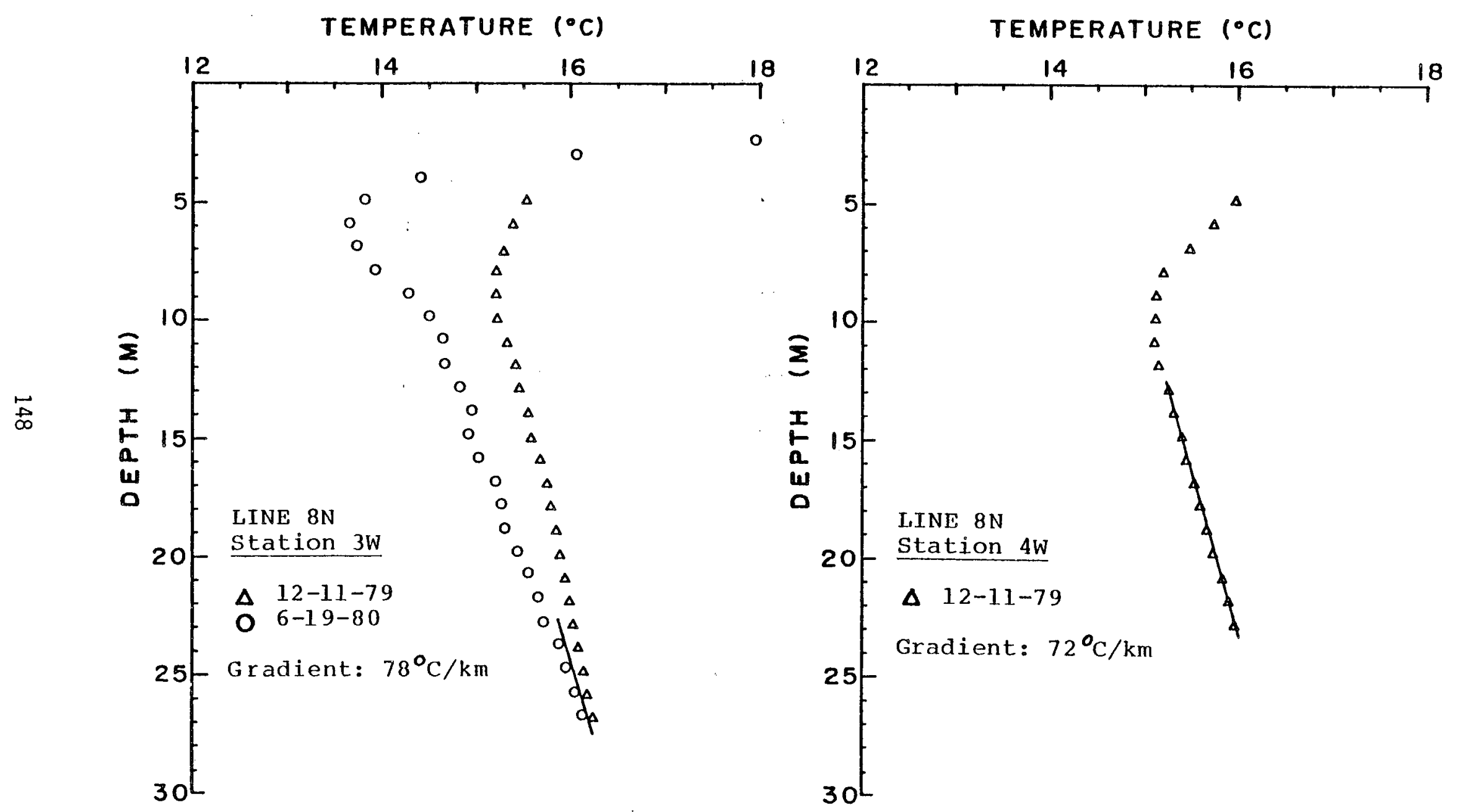



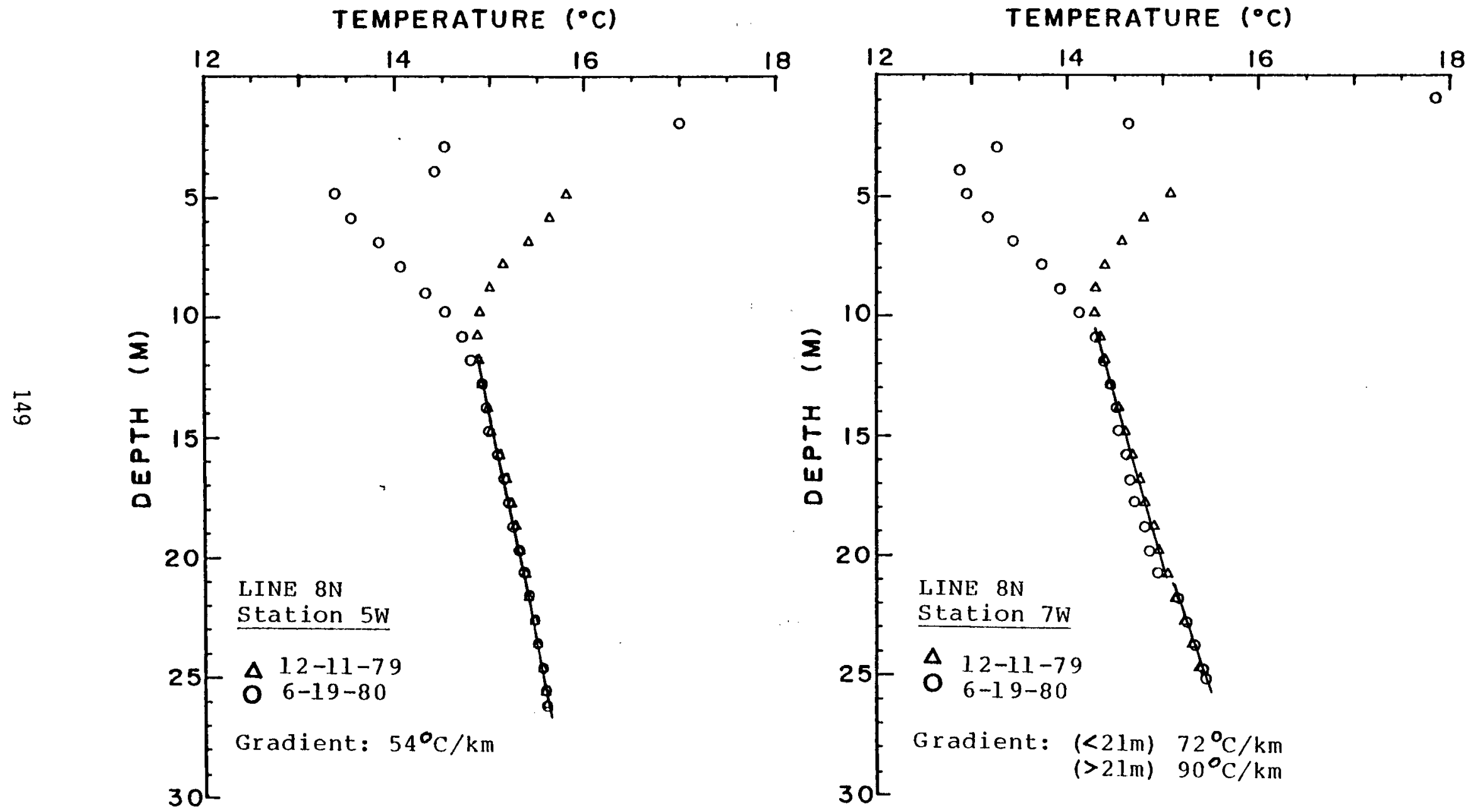


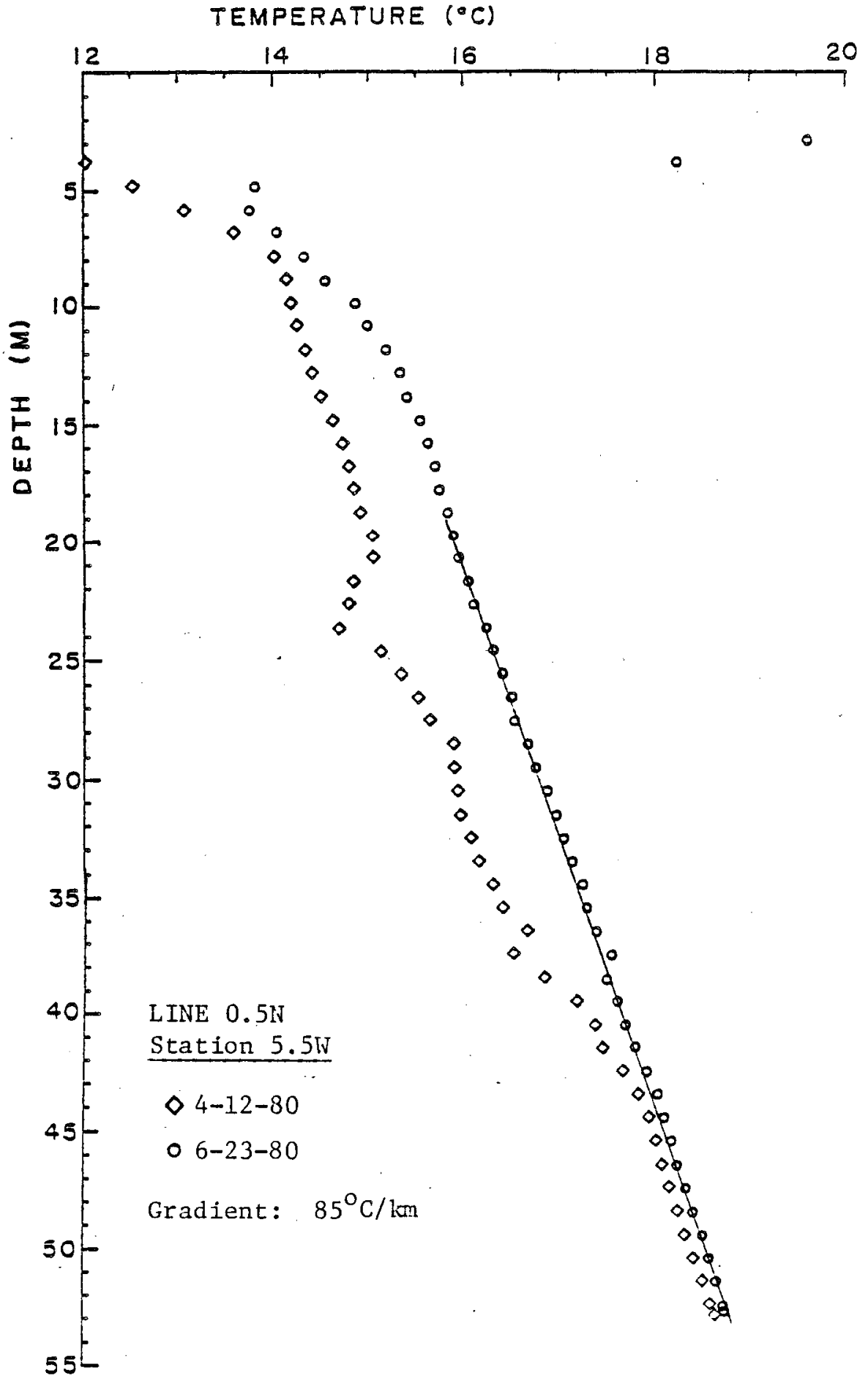


APPENDIX B

Geochemical Temperatures and Chemical

Data for Groundwaters in the Albuquerque Area. 
Table la

Geochemical Temperatures for Groundwaters in the Albuquerque Area

Data from this report

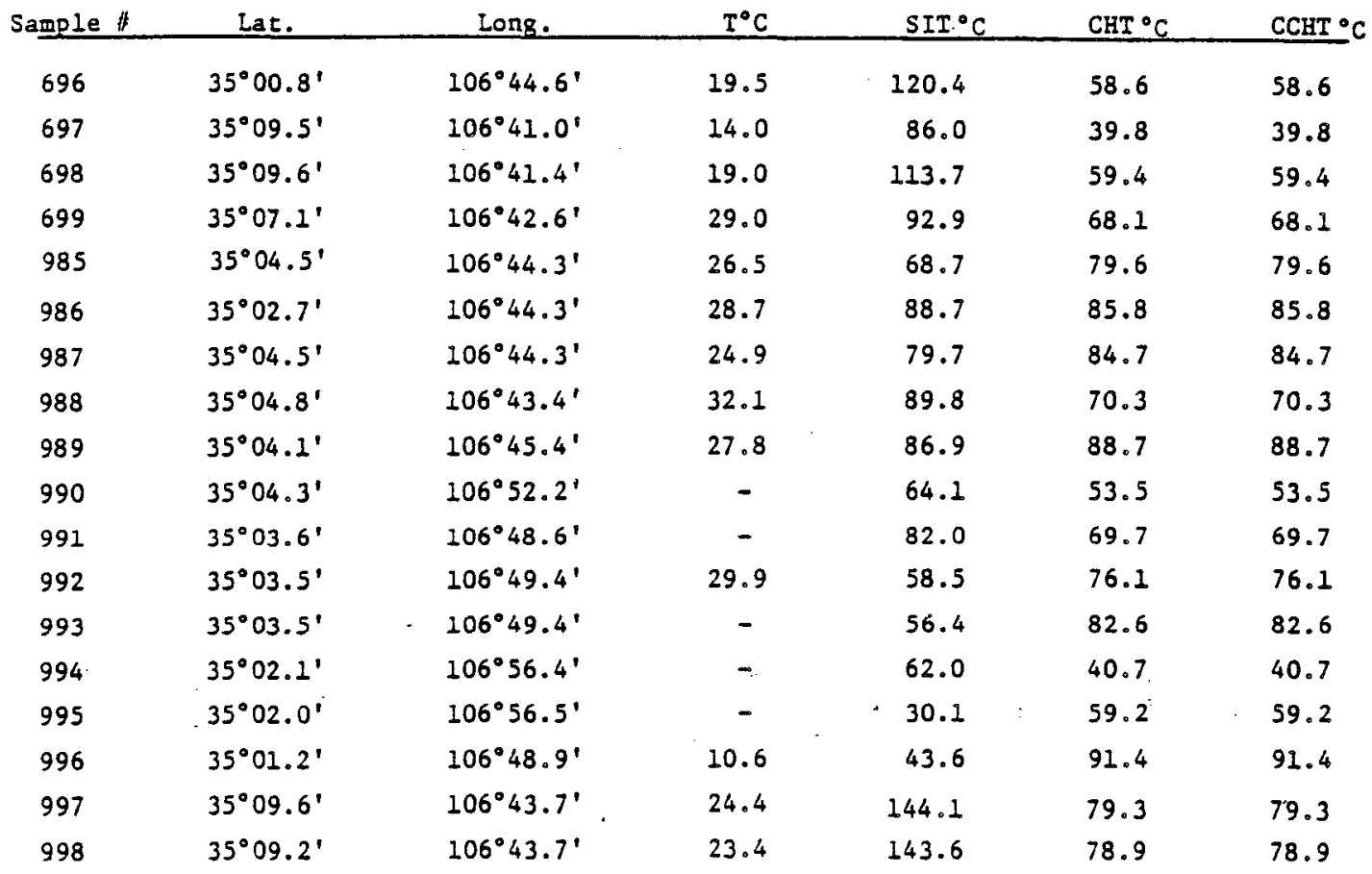


Tabie $1 b$

Geochemical Temperatures for Groundwaters in the Albuquerque Area Data from the USGS WATSTORE File

\begin{tabular}{|c|c|c|c|c|c|}
\hline Lat. & Long. & $\mathrm{I}^{\circ} \mathrm{C}$ & SII ${ }^{\circ} \mathrm{C}$ & $\mathrm{CHT}{ }^{\circ} \mathrm{C}$ & $\mathrm{CCHT}^{\circ} \mathrm{C}$ \\
\hline $35^{\circ} 00.1^{\prime}$ & $106^{\circ} 39.8^{\prime}$ & - & 108.9 & - & - \\
\hline $35^{\circ} 01.1^{\prime}$ & $106^{\circ} 41.5^{\prime}$ & - & 93.8 & - & - \\
\hline $35^{\circ} 01.9^{\prime}$ & $106^{\circ} 56.6^{\prime}$ & - & 48.0 & 95.5 & 44.1 \\
\hline $35^{\circ} 02.3^{\prime}$ & $106^{\circ} 43.6^{\prime}$ & 28.5 & 88.3 & 62.3 & 62.3 \\
\hline $35^{\circ} 02.8^{\prime}$ & $106^{\circ} 40.9^{\prime}$ & - & 99.0 & - & - \\
\hline $35^{\circ} 02.9^{\prime}$ & $106^{\circ} 39.1^{\prime}$ & 20.5 & 121.7 & 86.8 & 63.0 \\
\hline $35^{\circ} 03.1^{\prime}$ & $106^{\circ} 43.6^{\prime}$ & - & 90.6 & 63.1 & 63.1 \\
\hline $35^{\circ} 03.1^{\prime}$ & $106^{\circ} 43.6^{\prime}$ & 30.0 & 91.7 & 73.0 & 73.0 \\
\hline $35^{\circ} 03.1^{\prime}$ & $106^{\circ} 43.6^{\prime}$ & 19.5 & - & - & - \\
\hline $35^{\circ} 03.1^{\prime}$ & $106^{\circ} 43.6^{\prime}$ & 22.0 & - & - & - \\
\hline $35^{\circ} 03.1^{\prime}$ & $106^{\circ} 43.6^{\prime}$ & 21.5 & - & - & - \\
\hline $35^{\circ} 03.1^{\prime}$ & $106^{\circ} 43.6^{\prime}$ & 21.0 & - & - & - \\
\hline $35^{\circ} 04.7^{\prime}$ & $106^{\circ} 43.9^{\prime}$ & 34.5 & - & - & - \\
\hline $35^{\circ} 04.7^{\prime}$ & $106^{\circ} 43.9^{\prime}$ & 26.0 & - & - & - \\
\hline $35^{\circ} 04.8^{\prime}$ & $106^{\circ} 43.3^{\prime}$ & 40.5 & - & - & - \\
\hline $35^{\circ} 04.8^{\prime}$ & $106^{\circ} 43.3^{\prime}$ & 23.0 & - & - & - \\
\hline $35^{\circ} 04.9^{\prime}$ & $106^{\circ} 44.9^{\prime}$ & 30.0 & - & - & - \\
\hline $35^{\circ} 04.9^{\prime}$ & $106^{\circ} 44^{\prime} 9^{\prime}$ & 30.0 & - & - & - \\
\hline $35^{\circ} 05.0^{\prime}$ & $106^{\circ} 44.3^{\prime}$ & 31.1 & 93.8 & - & - \\
\hline $35^{\circ} 05 . I^{\prime}$ & $106^{\circ} 43.4^{\prime}$ & 30.0 & - & - & - \\
\hline $35^{\circ} 05.4^{\prime}$ & $106^{\circ} 40.6^{\prime}$ & 21.0 & 70.4 & 41.4 & 41.4 \\
\hline $35^{\circ} 06.0^{\prime}$ & $106^{\circ} 41.2^{\prime}$ & 16.0 & 65.3 & 36.8 & 36.8 \\
\hline $35^{\circ} 06.0^{\prime}$ & $106^{\circ} 41.2^{\prime}$ & 17.0 & 65.3 & 37.2 & 37.2 \\
\hline $35^{\circ} 06.0^{\prime}$ & $106^{\circ} 41.2^{\prime}$ & - & 20.0 & 42.0 & 42.0 \\
\hline $35^{\circ} 06.0^{\prime}$ & $106^{\circ} 41.2^{\prime}$ & - & 25.0 & 30.4 & 30.4 \\
\hline $35^{\circ} 06.0^{\prime}$ & $106^{\circ} 41.2^{\prime}$ & - & 48.0 & 49.7 & 49.7 \\
\hline $35^{\circ} 06.0^{\prime}$ & $106^{\circ} 41.2^{\prime}$ & - & 48.0 & 60.0 & 60.0 \\
\hline $35^{\circ} 06.0^{\prime}$ & $106^{\circ} 41.2^{\prime}$ & - & 29.8 & 58.8 & 58.8 \\
\hline $35^{\circ} 06.0^{\prime}$ & $106^{\circ} 41.2^{\prime}$ & - & 31.0 & 285.3 & 61.4 \\
\hline $35^{\circ} 09.6$ & $106^{\circ} 43.2$ & 23.5 & - & - & - \\
\hline $35^{\circ} 09.6^{\prime}$ & $106^{\circ} 43.2^{\prime}$ & 23.5 & - & - & - \\
\hline $35^{\circ} 10.2^{\prime}$ & $106^{\circ} 38.1^{\prime}$ & - & 79.4 & - & - \\
\hline $35^{\circ} 12.3^{\prime}$ & $106^{\circ} 42.2^{\prime}$ & - & 111.3 & - & - \\
\hline $35^{\circ} 12.3^{\prime}$ & $106^{\circ} 42.3^{\prime}$ & 21.0 & - & - & - \\
\hline $35^{\circ} 13.5^{\prime}$ & $106^{\circ} 40.2^{\prime}$ & - & 103.6 & - & - \\
\hline $35^{\circ} 14.2^{\prime}$ & $106^{\circ} 59.6^{\prime}$ & 26.0 & - & - & - \\
\hline
\end{tabular}


Table Ib

cont.

\begin{tabular}{cccccc} 
Lat. & Long. & $\mathrm{T}^{\circ} \mathrm{C}$ & SIT $^{\circ} \mathrm{C}$ & $\mathrm{CHT}^{\circ} \mathrm{C}$ & $\mathrm{CCHT}^{\circ} \mathrm{C}$ \\
\hline $35^{\circ} 14.4^{\prime}$ & $106^{\circ} 40.7^{\prime}$ & 13.0 & 118.2 & 71.3 & 71.3 \\
$35^{\circ} 14.6^{\prime}$ & $106^{\circ} 40.6^{\prime}$ & 21.0 & - & - & - \\
$35^{\circ} 14.8^{\prime}$ & $106^{\circ} 40.1^{\prime}$ & 16.0 & 110.5 & 62.1 & 62.1 \\
$35^{\circ} 14.8^{\prime}$ & $106^{\circ} 40.2^{\prime}$ & 19.0 & - & - & -
\end{tabular}


Table 1c

Geochemical Temperatures for Groundwaters in the Albuquerque Area

Data from the city of Albuquerque

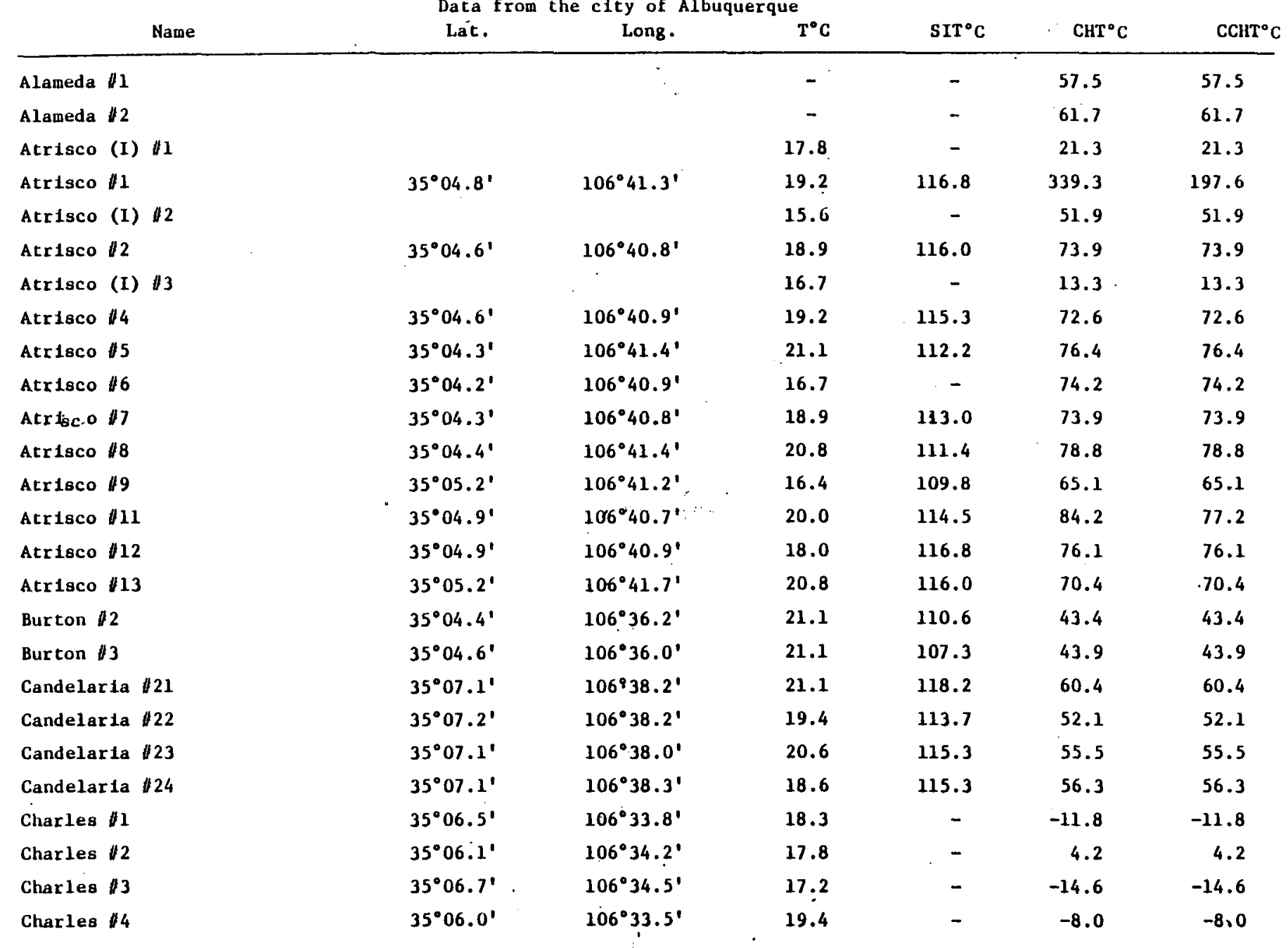


Table lc

cont.

\begin{tabular}{|c|c|c|c|c|c|c|}
\hline Name & Lat. & Long. & $\mathrm{T}^{\circ} \mathrm{C}$ & $\operatorname{SIT}{ }^{\circ} \mathrm{C}$ & $\operatorname{CHT}{ }^{\circ} \mathrm{C}$ & ccit ${ }^{\circ}$ \\
\hline Don $\| 1$ & $35^{\circ} 04.1^{\prime}$ & $106^{\circ} 45.4^{\prime}$ & 31.4 & 82.3 & 90.0 & 68.4 \\
\hline Duranes \#1 & $35^{\circ} 06.7^{\prime}$ & $106^{\circ} 40.1^{\prime}$ & 20.8 & 122.4 & 79.4 & 67.3 \\
\hline Duranes $\not 2$ & $35^{\circ} 07.2^{\prime}$ & $106^{\circ} 40.8^{\prime}$ & 19.4 . & 122.4 & 73.0 & 73.0 \\
\hline Duranes \#3 & $35^{\circ} 06.5^{\prime}$ & $106^{\circ} 40.7^{\prime}$ & 20.6 & 120.4 & 69.9 & 69.9 \\
\hline Duranes $\$ 4$ & $35^{\circ} 06.5^{\prime}$ & $106^{\circ} 41: 3^{\prime}$ & 22.2 & 118.2 & 81.0 & 81.0 \\
\hline Duranes $\| 5$ & $35^{\circ} 06.1^{\prime}$ & $106^{\circ} 41.3^{\prime}$ & 21.7 & 118.9 & 74.0 & 74.0 \\
\hline Duranes $\# 6$ & $35^{\circ} 06.9^{\prime}$ & $106^{\circ} 40.5^{\prime}$ & 20.6 & 121.1 & 69.7 & 69.7 \\
\hline Duranes $\# 7$ & $35^{\circ} 06.9^{\prime}$ & $106^{\circ} 41.2^{\prime}$ & 18.6 & 116.0 & 68.6 & 68.6 \\
\hline Griegos $\# 1$ & $35^{\circ} 08.4^{\prime}$ & $106^{\circ} 39.8^{\prime}$ & 18.9 & 120.4 & 61.6 & 61.6 \\
\hline Griegos $/ 2$ & $35^{\circ} 07.8^{\prime}$ & $106^{\circ} 40.1^{\prime}$ & 20.0 & 126.4 & 65.3 & 65.3 \\
\hline Griegos \#3 & $35^{\circ} 08.1^{\prime}$ & $106^{\circ} 40.4^{\prime}$ & 18.9 & 182.4 & 67.0 & 67.0 \\
\hline Griegos \#4 & $35^{\circ} 08.4^{\prime}$ & $106^{\circ} 39.0^{\prime}$ & 19.4 & 122.4 & 72.1 & 68.6 \\
\hline Griegos $\# 5$ & $35^{\circ} 08.1$ & $106^{\circ} 39.4^{\circ}$ & 19.4 & 120.4 & 70.7 & 69.1 \\
\hline Leavitt $\# 1$ & & & 21.1 & - & 20.7 & 20.7 \\
\hline Leavitt $\| 2$ & & $\ldots$ & 30.0 & - & - & - \\
\hline Leyendecker $\| 1$ & $35^{\circ} 07.9^{\prime}$ & $106^{\circ} 34.4^{\prime}$ & 19.7 & 84.8 & 24.7 & 24.7 \\
\hline Leyendecker \#2 & $35^{\circ} 07.5^{\prime}$ & $106^{\circ} 34.1^{\prime}$ & 20.0 & 84.8 & 35.3 & 35.3 \\
\hline Leyendecker \#3 & $35^{\circ} 08.3^{\prime}$ & $106^{\circ} 34.6^{\prime}$ & 16.7 & - & - & - \\
\hline Leyendecker \#4 & $35^{\circ} 08.2^{\prime}$ & $106^{\circ} 34.1^{\prime}$ & 20.6 & 90.7 & 25.3 & 25.3 \\
\hline Lomas $\# 1$ & $35^{\circ} 04.5^{\prime}$ & $106^{\circ} 30.4^{\prime}$ & 20.6 & 72.3 & 36.5 & 36.5 \\
\hline Lomas \#2 & $35^{\circ} 05.0^{\prime}$ & $106^{\circ} 30.8^{\prime}$ & 22.8 & - & $-10: 0$ & -10.0 \\
\hline Lomas \#3 & $35^{\circ} 05.5^{\prime}$ & $106^{\circ} 30.6^{\prime}$ & 22.8 & - & -14.5 & -14.5 \\
\hline Lomas 14 & $35^{\circ} 05.8^{\prime}$ & $106^{\circ} 31.1^{\prime}$ & 22.8 & - & -8.6 & -8.6 \\
\hline Love $\| 1$ & $35^{\circ} 05.3^{\prime}$ & $106^{\circ} 31.7^{\prime}$ & 24.4 & 83.6 & 40.7 & 40.7 \\
\hline Love $\sharp 2$ & $35^{\circ} 04.8^{\prime}$ & $106^{\circ} 32.0^{\prime}$ & 23.9 & 83.6 & 37.5 & 37.5 \\
\hline Love $\# 3$ & $35^{\circ} 05.2^{\prime}$ & $106^{\circ} 32.3^{\prime}$ & 23.9 & 84.8 & 36.5 & 36.5 \\
\hline
\end{tabular}


Table 1c

cont.

\begin{tabular}{|c|c|c|c|c|c|c|}
\hline Name & l.at. & Long. & $\mathrm{T}^{\circ} \mathrm{C}$ & $\operatorname{sIT}^{\circ} \mathrm{C}$ & $\operatorname{CHT}^{\circ} \mathrm{C}$ & Сснт ${ }^{\circ} \mathrm{C}$ \\
\hline Love 114 & $35^{\circ} 05.2^{\prime}$ & $106^{\circ} 33.0^{\prime}$ & 23.3 & 89.6 & 34.7 & 34.7 \\
\hline Love $\| 5$ & $35^{\circ} 04.8^{\prime}$ & $106^{\circ} 32.7^{\prime}$ & 23.3 & 82.3 & 41.8 & 41.8 \\
\hline Love 16 & $35^{\circ} 05.9^{\prime}$ & $.106^{\circ} 31.6^{\prime}$ & 20.6 & - & -9.8 & -9.8 \\
\hline Love $\| 7$ & $35^{\circ} 06.1^{\prime}$ & $106^{\circ} 32.2^{\circ}$ & 22.2 & - & -4.8 & -4.8 \\
\hline Miles \#I & $35^{\circ} 03.1^{\prime}$ & $106^{\circ} 37: 8^{\prime}$ & - & - & 4.8 & 4.8 \\
\hline Ponderosa \|1 & $35^{\circ} 07.8^{\prime}$ & $106^{\circ} 31.2^{\prime}$ & 25.0 & - & 21.1 & 21.1 \\
\hline Ponderosa $\| 2$ & $35^{\circ} 03.0^{\prime}$ & $106^{\circ} 31,9^{\prime}$ & 24.4 & - & -32.7 & -32.7 \\
\hline Ponderosa & & . & 25.6 & - & 15.1 & 15.1 \\
\hline Ponderosa $\| 7$ & & . & 25.8 & - & - & - \\
\hline Sta. Barbara \#1 & $35^{\circ} 06.8^{\prime}$ & $106^{\circ} 36.4^{\prime}$ & 18.9 & 90.7 & 36.6 & 36.6 \\
\hline San Jose $\| 1$ & $35^{\circ} 03.3^{\prime}$ & $106^{\circ} 38.7^{\prime}$ & 13.9 & - & 5.6 & 5.6 \\
\hline San Jose $/ 2$ & $35^{\circ} 03.2^{\prime}$ & $106^{\circ} 39.0^{\prime}$ & 26.1 & 127.0 & 84.5 & 81.2 \\
\hline San Jose \#3 & $35^{\circ} 03.0^{\prime}$ & $106^{\circ} 38.6^{\prime}$ & 26.1 & - & 77.7 & 66.3 \\
\hline San Jose \#4 & & & 24.4 & - & 34.2 & 34.2 \\
\hline San Jose $\forall 7$ & & & 26.1 & - & 74.3 & 72.5 \\
\hline San Jose $\$ 5$ & & & 23.3 & - & 28.3 & 28.3 \\
\hline San Jose $\# 6$ & & & 22.8 & - & 18.2 & 18.2 \\
\hline San Jose \#8 & & & 25.8 & - & 82.7 & 66.4 \\
\hline San Jose 10 & $35^{\circ} 02.9^{\prime}$ & $106: 38.7^{\prime}$ & 26.1 & - & 73.8 & 73.8 \\
\hline Thomas \#1 & $35^{\circ} 07.9^{\prime}$ & $106^{\circ} 32.9^{\circ}$ & 23.3 & - & 32.6 & 32.6 \\
\hline Thomas $\| 2$ & $35^{\circ} 07.8^{\prime}$ & $106^{\circ} 32.6^{\prime}$ & 25.6 & - & 32.2 & 32.2 \\
\hline Thomas \#3 & $35^{\circ} 08.3^{\prime}$ & $106^{\circ} 33.2^{\prime}$ & 22.2 & - & 31.8 & 31.8 \\
\hline Thomas $\# 4$ & $35^{\circ} 08.2^{\prime}$ & $106^{\circ} 32.7^{\prime}$ & 25.0 & - & 35.8 & 35.8 \\
\hline Valley Gardens A & $35^{\circ} 00.5^{\prime}$ & $106^{\circ} 42.4^{\prime}$ & 23.3 & 112.2 & 70.0 & 70.0 \\
\hline Volandia $\| 1$ & $35^{\circ} 08.1^{\prime}$ & $106^{\circ} 35.8^{\prime}$ & 17.8 & - & 28.6 & 28.6 \\
\hline Voland $1 \mathrm{a} \| 2$ & $35^{\circ} 07.5^{\prime}$ & $106^{\circ} 35.0^{\prime}$ & 18.3 & - & 27.2 & 27.2 \\
\hline
\end{tabular}


Table Ic

cont.

\begin{tabular}{|c|c|c|c|c|c|c|}
\hline Name & Lat. & Long. & $\mathrm{T}^{\circ} \mathrm{C}$ & $\operatorname{sIT}{ }^{\circ} \mathrm{C}$ & $\operatorname{cHT}^{\circ} \mathrm{C}$ & $\mathrm{CCHT}^{\circ} \mathrm{C}$ \\
\hline Voland 1a $\| 3$ & $35^{\circ} 07.7^{\prime}$ & $106^{\circ} 36.3^{\prime}$ & 19.1 & - & 31.5 & 31.5 \\
\hline Volandia $\| 4$ & $35^{\circ} 08.0^{\prime}$ & $106^{\circ} 35.2^{\circ}$ & 18.6 & - & 26.3 & 26.3 \\
\hline Volandia / 5 & $35^{\circ} 08.1^{\prime}$ & $106^{\circ} 36.1^{\prime}$ & - & - & 31.6 & 31.6 \\
\hline Voland Ia $\| 6$ & $35^{\circ} 08.4^{\prime}$ & $106^{\circ} 35.4^{\prime}$ & 15.6 & - & -38.6 & -38.6 \\
\hline Volcano cliffs \#1 & $35^{\circ} 09.6^{\prime}$ & $106^{\circ} 43: 7^{\prime}$ & 25.8 & 118.2 & 192.4 & 192.4 \\
\hline Volcano cliffs & $35^{\circ} 09.2^{\prime}$ & $106^{\circ} 43.7^{\prime}$ & 21.7 & - & 27.5 & 27.5 \\
\hline West Mesa \#1 & $35^{\circ} 04.5^{\prime}$ & $106^{\circ} 44.2^{\prime}$ & 32.2 & 69.0 & 74.8 & 51.5 \\
\hline West Mesa $\# 2$ & $35^{\circ} 05.1^{\prime}$ & $106^{\circ} 43.9^{\prime}$ & 30.6 & 87.3 & 81.1 & 79.3 \\
\hline West Mesa $\| 3$ & $35^{\circ} 04.7^{\prime}$ & $106^{\circ} 43.9^{\prime}$ & 22.8 & - & 24.3 & 24.3 \\
\hline West Mesa $\# 4$ & $35^{\circ} 04.8^{\prime}$ & $106^{\circ} 43.4^{\prime}$ & 31.7 & - & 8.8 & 8.8 \\
\hline Yale \#1 & & & - & - & 49.7 & 49.7 \\
\hline Yale \#2 & & & 18.3 & - & -7.1 & -7.1 \\
\hline Yale 3 & $35^{\circ} 04.0^{\prime}$ & $106^{\circ} 37.5^{\prime}$ & - & - & 1.1 & 1.1 \\
\hline & & , & - & - & 14.6 & 14.6 \\
\hline Valley Gardens B \#1 & $35^{\circ} 00.7^{\prime}$ & $106^{\circ} 42.2^{\prime}$ & - & - & - & - \\
\hline Plant $\| 2 \mathrm{Lab}$ & & & 23.9 & 123.1 & 79.9 & 73.3 \\
\hline Sunset Gardens \& Atrisco & & & 15.0 & - & 47.1 & 47.1 \\
\hline Second \& Ranchitos & & & 10.0 & - & 26.3 & 26.3 \\
\hline 4600 Rio Grande & & . & 16.1 & - & 13.4 & 13.4 \\
\hline Rice \& Zickert & & & 18.9 & - & 32.1 & 32.1 \\
\hline City Hall & & & 17.8 & - & 72.7 & 72.7 \\
\hline Woodward at G. E. & & & 22.2 & - & 76.3 & 52.0 \\
\hline Vall \& Hermosa & & & 20.0 & - & 34.8 & 34.8 \\
\hline Sigma Chi \& Universify & & & 21.1 & - & 53.5 & 53.5 \\
\hline Amherst \& Candelaria & & & 11.1 & - & 26.0 & 26.0 \\
\hline City Yards & & & 13.9 & - & 27.1 & 27.1 \\
\hline Wyom Ing \& Osuna & & & 20.0 & - & 28.1 & 28.1 \\
\hline
\end{tabular}


Table Ic

\begin{tabular}{|c|c|c|c|c|c|}
\hline Name & Long. & $\mathrm{T}^{\circ} \mathrm{C}$ & $\operatorname{SIT}^{\circ} \mathrm{C}$ & $\mathrm{CHTr}^{\circ} \mathrm{C}$ & $\mathrm{CCHT}^{\circ} \mathrm{C}$ \\
\hline General Stillwell \& Shoshone & & 19.4 & - & 28.9 & 28.9 \\
\hline Kentucky \& Southern & & 18.9 & - & 31.0 & 31.0 \\
\hline Morris \& Huerfana & & 22.2 & - & 33.7 & 33.7 \\
\hline Moon \& Hannett & & 18.9 & - & 32.0 & 32.0 \\
\hline Juan Tabo Nassau & & 21.1 & - & 27.1 & 27.1 \\
\hline Montgomery \& Sunset Canyon & & 18.9 & - & 26.8 & 26.8 \\
\hline Blackhills Ct. Blackh1lls Rd. & & 17.8 & - & 24.6 & 24.6 \\
\hline Kirby \& PIneridge & & 18.9 & - & 31.1 & 31.1 \\
\hline Tramway \& Copper & & 17.8 & - & 32.8 & 32.8 \\
\hline Stagecoach \& Stagecoach & & 18.9 & - & 36.0 & 36.0 \\
\hline Well "2 Plant $/ 2$ & & 18.3 & 118.2 & 70.3 & 44.7 \\
\hline 1403 Isleta SW & $\cdot$ & - & - & - & - \\
\hline 2605 San Isidro & & - & - & 65.8 & 65.8 \\
\hline East Drain \& Barelas Bridge & & - & - & 41.7 & 41.7 \\
\hline Rio Grande River \& Isleta Diversion & $\because$ & - & - & 54.6 & 54.6 \\
\hline 841 Palamosa SE & & - & - & 45.9 & 45.9 \\
\hline 841 Palamosa SE w/carbon filter & . & - & - & 55.5 & 55.5 \\
\hline 841 Palamosa SE w/ mixed bed cartridge & & - & - & - & - \\
\hline Plant 1 Eff. Comp. & & - & - & 191.1 & 35.5 \\
\hline Plant \| 2 Eff. Comp. & & - & - & 182.8 & 37.8 \\
\hline Conchas Ranch & & - & - & 32.7 & 32.7 \\
\hline 717 Coal SE & & - & - & - & - \\
\hline Public Library Fifth \& Copper & & - & - & - & - \\
\hline 210 Cagua NE & . & - & - & - & - \\
\hline Hydrant Fifth \& Copper & & $\because$ & - & - & - \\
\hline Lomas Reservoir & & 18.9 & - & 2.9 & $2 \ldots 9$ \\
\hline Yale Reservolr & & 18.3 & - & 40.7 & 40.7 \\
\hline
\end{tabular}


Table 1c

cont.

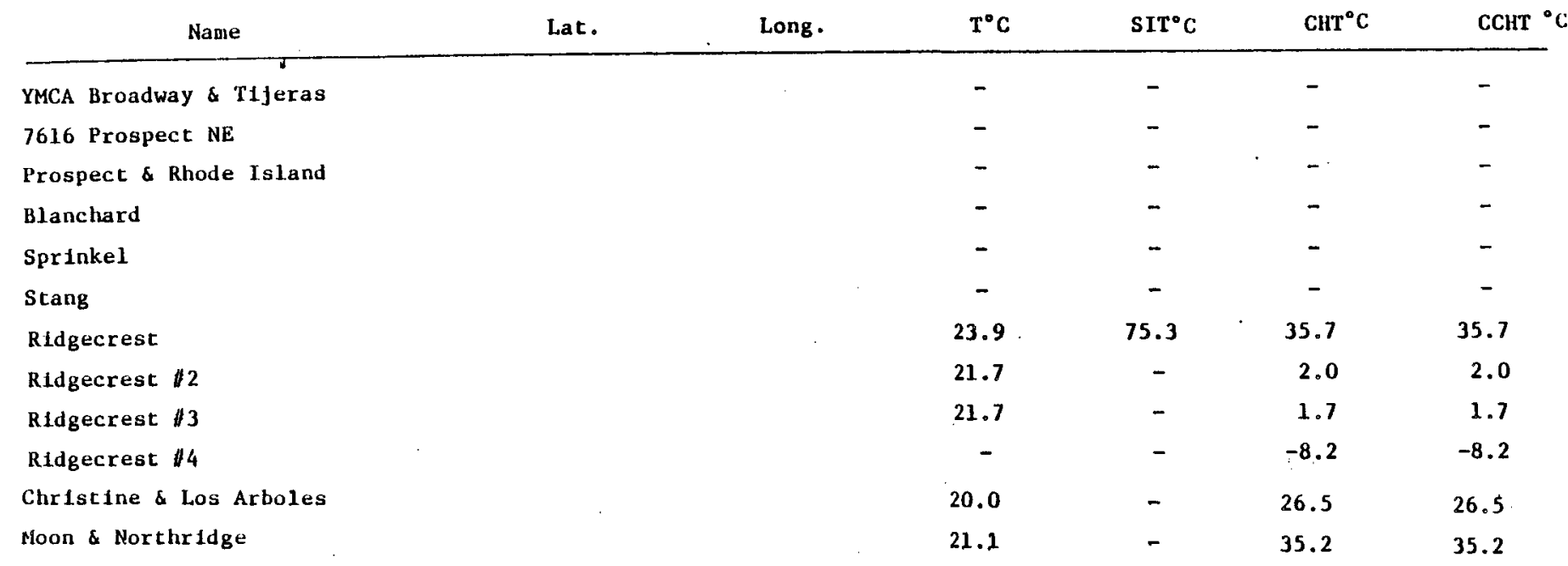


Table $2 a$

Chemlcal Daca for Groundwaters in the Albuquerque Area

Data from this report

\begin{tabular}{|c|c|c|c|c|c|c|c|c|}
\hline Sample & $\#$ & $\mathrm{Na}$ & $\mathrm{K}$ & $\mathrm{Ca}$ & $\mathrm{Mg}$ & $\mathrm{S} \mathrm{O}_{2}$ & $F$ & TDS \\
\hline 696 & & 46.0 & 5.9 & 40.5 & 10.3 & 73.0 & 0.56 & 312 \\
\hline 697 & & 41.6 & 3.9 & 58.1 & 7.5 & 35.0 & 0.26 & 316 \\
\hline 698 & & 40.0 & 9.0 & 68.3 & 12.0 & 64.0 & 0.29 & 400 \\
\hline 699 & & 106.0 & 1.6 & 5.4 & 0.8 & 41.0 & 1.25 & 288 \\
\hline 985 & & 124.1 & 1.2 & 2.2 & 0.1 & 22.8 & 1.20 & - \\
\hline 986 & & 145.3 & 1.2 & 1.8 & 0.1 & 37.2 & 1.13 & - \\
\hline 987 & & 104.6 & 1.9 & 3.2 & 0.4 & 30.1 & 1.32 & - \\
\hline 988 & & 117.0 & 0.8 & 1.8 & 0.2 & 38.3 & 0.83 & - \\
\hline 989 & & 117.5 & 1.6 & 2.2 & 0.1 & 35.7 & 0.91 & - \\
\hline 990 & & 200.0 & 4.7 & 78.3 & 14.6 & 20.3 & 0.70 & - \\
\hline 991 & & 101.8 & 3.1 & 13.2 & 1.2 & 31.9 & 0.66 & - \\
\hline 992 & & 103.4 & 3.1 & 9.8 & 0.7 & 17.5 & 0.66 & - \\
\hline 993 & & 100.2 & 3.5 & 8.6 & 0.7 & 16.4 & 0.65 & - \\
\hline 994 & 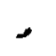 & $219.8^{\circ}$ & 5.9 & 235.5 & 68.7 & 19.1 & 0.54 & - \\
\hline 995 & & 387.8 & 5.5 & 102.8 & 24.4 & 7.5 & 0.82 & - \\
\hline 996 & & 98.6 & 3.5 & 5.8 & 0.8 & 11.3 & 0.68 & - \\
\hline 997 & & 54.0 & 6.6 & 19.0 & 4.0 & 113.0 & 0.87 & - \\
\hline 998 & & 48.7 & 7.0 & 20.0 & 4.2 & 112.0 & 0.86 & - \\
\hline
\end{tabular}


Table 2b

Chemical Data for Groundwaters in the Albuquerque Area

Data from USGS WATSTORE File

\begin{tabular}{|c|c|c|c|c|c|c|c|c|c|}
\hline Lat. & Location & Long. & $\mathrm{Na}$ & K & $\mathrm{Ca}$ & $\mathrm{Mg}$ & $\mathrm{S} \mathrm{O}_{2}$ & $\mathbf{F}$ & TDS \\
\hline $35^{\circ} 00.1^{\prime}$ & & $106^{\circ} 39.8^{\prime}$ & 19.0 & - & 42.0 & 6.1 & 58.0 & 0.5 & $24 !$ \\
\hline $35^{\circ} 01.1^{\prime}$ & & $106^{\circ} 41.5^{\prime}$ & 54.0 & - & 102.0 & 15.0 & 42.0 & 0.4 & 546 \\
\hline $35^{\circ} 01.9^{\prime}$ & & $106^{\circ} 56.6^{\prime}$ & 1000.0 & 7.1 & 45.0 & 13.0 & 13.0 & 3.4 & 3030 \\
\hline $35^{\circ} 02.3^{\prime}$ & & $106^{\circ} 43.6^{\prime}$ & 140.0 & 0.9 & 3.5 & 0.3 & 37.0 & 1.2 & 424 \\
\hline $35^{\circ} 02.8^{\prime}$ & . & $106^{\circ} 40.9^{\prime}$ & 65.0 & - & 39.0 & 11.0 & 47.0 & 0.5 & 372 \\
\hline $35^{\circ} 02.9^{\prime}$ & & $106^{\circ} 39.1^{\prime}$ & 77.0 & 8.3 & 23.0 & 5.4 & 75.0 & 0.8 & 376 \\
\hline $35^{\circ} 03.1^{\prime}$ & & $106^{\circ} 43.6^{\prime}$ & 110.0 & 1.0 & 3.5 & 0.5 & 39.0 & 0.9 & 337 \\
\hline $35^{\circ} 03.1^{\prime}$ & & $106^{\circ} 43.6^{\prime}$ & 110.0 & 2.0 & 6.1 & 0.4 & 40.0 & 1.1 & 351 \\
\hline $35^{\circ} 03.1^{\prime}$ & & $106^{\circ} 43.6^{\prime}$ & - & - & $=$ & 8.0 & - & - & - \\
\hline $35^{\circ} 03.1^{\prime}$ & & $106^{\circ} 43.6^{\prime}$ & - & - & - & 0.6 & - & - & - \\
\hline $35^{\circ} 03.1^{\prime}$ & & $106^{\circ} 43.6^{\prime}$ & - & - & - & 4.0 & - & - & - \\
\hline $35^{\circ} 03.1^{\circ}$ & $\cdot$ & $106^{\circ} 43.6^{\circ}$ & - & - & - & 1.4 & - & - & - \\
\hline $35^{\circ} 04.7^{\circ}$ & & $106^{\circ} 43.9^{\prime}$ & - & - & - & - & - & - & - \\
\hline $35^{\circ} 04.7^{\prime}$ & & $106^{\circ} 43.9^{\prime}$ & - & - & - & - & - & - & - \\
\hline $35^{\circ} 04.8^{\circ}$ & & $106^{\circ} 43.3^{\prime}$ & - & - & - & - & - & - & - \\
\hline $35^{\circ} 04.8^{\prime}$ & & $106^{\circ} 43.3^{\prime}$ & - & - & - & - & - & - & - \\
\hline $35^{\circ} 04.9^{\prime}$ & & $106^{\circ} 44.9^{\prime}$ & - & - & - & - & - & 1.8 & - \\
\hline $35^{\circ} 04.9^{\prime}$ & & $106^{\circ} 44.9^{\prime}$ & - & - & - & - & - & 2.2 & - \\
\hline $35^{\circ} 05.0^{\prime}$ & & $106^{\circ} 44.3^{\prime}$ & 112.0 & - & 1.1 & 0.6 & 42.0 & 1.0 & 336 \\
\hline $35^{\circ} 05.1^{\prime}$ & & $106^{\circ} 43.4^{\circ}$ & - & - & - & - & - & $\because \quad 1.2$ & - \\
\hline $35^{\circ} 05.4^{\prime}$ & & $106^{\circ} 40.6^{\prime}$ & 34.0 & 4.0 & 50.0 & 14.0 & 24.0 & 0.5 & 325 \\
\hline $35^{\circ} 06.0^{\prime}$ & & $106^{\circ} 41.2^{\circ}$ & 30.0 & . $\quad 3.4$ & 48.0 & 11.0 & 21.0 & 0.5 & 286 \\
\hline $35^{\circ} 06.0^{\prime}$ & & $106^{\circ} 41.2^{\prime}$ & 30.0 & 3.6 & 51.0 & 11.0 & 21.0 & 0.5 & 295 \\
\hline $35^{\circ} 06.0^{\circ}$ & & $106^{\circ} 41.2^{\prime}$ & 17.0 & 5.1 & 49.0 & 11.0 & 5.3 & 1.1 & 244 \\
\hline $35^{\circ} 06.0^{\prime}$ & & $106^{\circ} 41.2^{\prime}$ & 17.0 & 2.0 & 24.0 & 7.0 & 6.3 & 1.0 & 154 \\
\hline
\end{tabular}


Table 2b

cont.

\begin{tabular}{|c|c|c|c|c|c|c|c|c|}
\hline Lat. & Location & $\mathrm{Na}$ & $\mathbf{K}$ & $\mathrm{Ca}$ & $\mathrm{Mg}_{\mathbf{g}}$ & $\mathrm{S} \mathrm{O}_{2}$ & F & TDS \\
\hline $35^{\circ} 06.0^{\prime}$ & $106^{\circ} 41.2^{\prime \prime}$ & 12.0 & 4.2 & 20.0 & 3.4 & 13.0 & 1.1 & 125 \\
\hline $35^{\circ} 06.0^{\prime}$ & $106^{\circ} 41.2^{\prime}$ & 25.0 & 9.7 & 59.0 & 11.0 & 13.0 & 1.0 & 312 \\
\hline $35^{\circ} 06.0^{\prime}$ & $106^{\circ} 41.2^{\prime}$ & 25.0 & 3.4 & 13.0 & 2.0 & 7.4 & 1.4 & 126 \\
\hline $35^{\circ} 06.0^{\prime}$ & $106^{\circ} 41.2^{\prime}$ & 120.0 & 14.0 & 15.0 & 4.5 & 7.7 & 0.9 & 417 \\
\hline $35^{\circ} 09.6^{\prime}$ & $106^{\circ} 43.2^{\prime}$ & - & - & 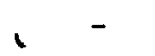 & - & - & 1.0 & - \\
\hline $35^{\circ} 09.6^{\prime}$ & $106^{\circ} 43.2^{\prime}$ & - & - & - & - & - & 1.0 & - \\
\hline $35^{\circ} 12.3^{\prime}$ & $106^{\circ} 42.2^{\prime}$ & 32.0 & - & 34.0 & 7.5 & 61.0 & 0.5 & 262 \\
\hline $35^{\circ} 12.3^{\prime}$ & $106^{\circ} 42.3^{\prime}$ & - & - & - & - & - & 0.8 & - \\
\hline $35^{\circ} 13.5^{\circ}$ & $106^{\circ} 40.2^{\prime}$ & 29.0 & 0 & 57.0 & 10.0 & 52.0 & 0.5 & 327 \\
\hline $35^{\circ} 14.2^{\prime}$ & $106^{\circ} 59.6^{\prime}$ & 3200.0 & 10.0 & - & - & - & - & - \\
\hline $35^{\circ} 14.4^{\circ}$ & $106^{\circ} 40.7^{\prime}$ & 36.0 & 7.6 & 28.0 & 5.0 & 70.0 & 0.3 & 267 \\
\hline $35^{\circ} 14.6^{\prime}$ & $106^{\circ} 40.6^{\prime}$ & - & - & - & - & - & 1.0 & - \\
\hline $35^{\circ} 14.8^{\prime}$ & $106^{\circ} 40.1^{\prime}$ & 30.0 & 6.4 & 31.0 & 5.9 & 60.0 & 0.4 & 255 \\
\hline $35^{\circ} 14.8^{\circ}$ & $106^{\circ} 40.2^{\prime}$ & - & - & - & - & - & 0.5 & - \\
\hline
\end{tabular}


Table 2c

Chemical Data for Groundwaters in the Albuquerque Area

Data from the city of Albuquerque

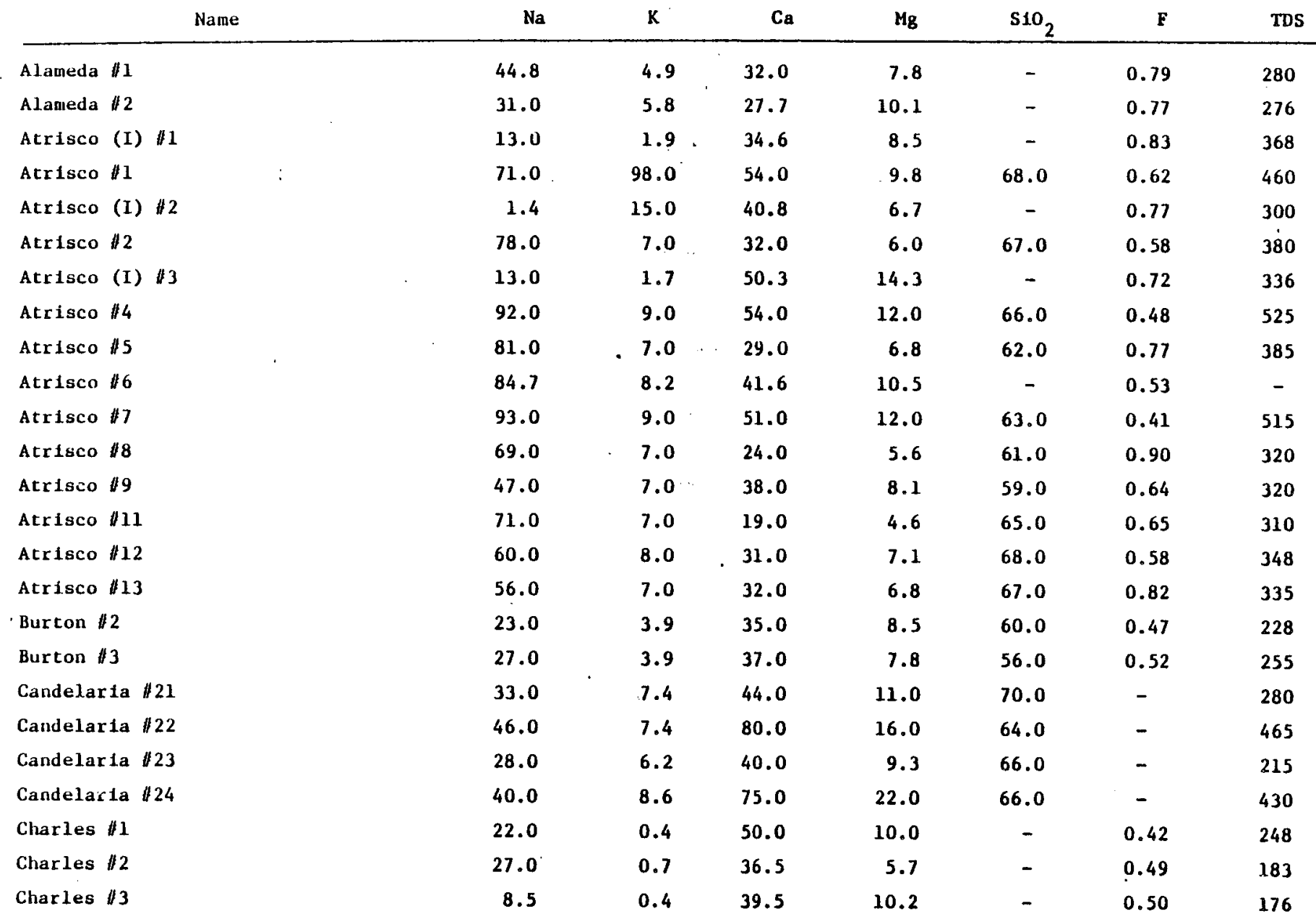


Table 2c

cont.

\begin{tabular}{|c|c|c|c|c|c|c|c|}
\hline Name & $\mathrm{Na}$ & $\mathbf{k}$ & $\mathbf{C a}$ & Mg & $\mathrm{SHO}_{2}$ & $\cdot \mathbf{F}$ & TDS \\
\hline Charles & 30.0 & 0.5 & 59.7 & 5.6 & - & 0.33 & 308 \\
\hline Don $\| 1$ & 143.0 & 2.0 & 3.2 & 1.0 & 32.0 & 1.55 & 420 \\
\hline Duranes $\#$ & 62.0 & 8.2 & 28.0 & 8.5 & 76.0 & 0.68 & 325 \\
\hline Duranes $\| 2$ & 51.0 & 7.0 & 27.0 & 7.2 & 76.0 & 0.57 & 278 \\
\hline Duranes \#3 & 60.0 & 7.8 & 40.0 & 10.0 & 73.0 & 0.52 & 353 \\
\hline Duranes $\| 4$ & 76.0 & 6.2 & 19.0 & 4.1 & 70.0 & 1.00 & 310 \\
\hline Duranes 15 & 62.0 & 6.6 & 26.0 & 5.5 & 71.0 & 0.94 & 280 \\
\hline Duranes $\$ 6$ & 44.0 & 8.6 & 40.0 & 9.9 & 74.0 & 0.42 & 303 \\
\hline Duranes $\$ 7$ & 53.0 & 7.0 & 34.0 & 8.0 & 67.0 & 0.70 & 330 \\
\hline Griegos $\| 1$ & 21.0 & 7.4 & 33.0 & 10.0 & 73.0 & 0.43 & 210 \\
\hline Griegos $\| 2$ & 33.0 & 9.0 & 46.0 & 13.0 & 82.0 & 0.37 & 320 \\
\hline Criegos $\| 3$ & 44.0 & 6.2 & +28.0 & 7.6 & 76.0 & 0.46 & $25 \dot{5}$ \\
\hline Grlegos & 37.0 & 7.0 & 24.0 & 7.6 & 76.0 & 0.65 & 235 \\
\hline Griegos $\$ 5$ & 46.0 & 8.6 & 39.0 & 12.0 & 73.0 & 0.59 & 295 \\
\hline Leavitt $\| 1$ & 43.0 & 0.4 & 6.3 & 5.7 & - & 1.28 & 290 \\
\hline Leavitc $\| 2$ & 105.8 & 1.5 & 4.8 & - & - & 1.52 & 305 \\
\hline Leyendecker \#1 & 21.0 & 2.0 & 38.0 & 4.4 & 34.0 & 0.49 & 200 \\
\hline Leyendecker & 23.0 & 3.0 & 38.0 & 4.0 & 34.0 & 0.48 & 210 \\
\hline Leyendecker \#3 & - & 0.4 & 36.5 & 7.6 & - & 0.52 & 176 \\
\hline Leyendecker $\$ 4$ & 25.0 & 2.0 & 40.0 & 5.0 & 39.0 & 0.51 & 223 \\
\hline Lomas 1 & 28.0 & 4.0 & 60.0 & 10.0 & 25.0 & 0.49 & 305 \\
\hline Lomas \#2 & 12.0 & 0.5 & 44.4 & 4.7 & - & 0.53 & 213 \\
\hline Lomas & 12.5 & 0.7 & 110.0 & 6.7 & - & 0.55 & 263 \\
\hline Lomas $\# 4$ & 12.0 & 0.5 & 39.6 & 7.3 & - & 0.52 & 200 \\
\hline Love $\| 1$ & 35.0 & 2.7 & 29.0 & 3.5 & 33.0 & 0.74 & 145 \\
\hline
\end{tabular}


Table 2c

cont.

\begin{tabular}{|c|c|c|c|c|c|c|c|}
\hline Name & $\mathrm{Na}$ & $\mathrm{K}^{*}$ & $\mathrm{Ca}$ & $\mathbf{M g}_{\mathbf{g}}$ & $\mathrm{SiO}_{2}$ & $\mathbf{F}$ & TDS \\
\hline Love $\# 2$ & 33.0 & 2.7 & 34.0 & 4.8 & 33.0 & 0.74 & 173 \\
\hline Love $\# 3$ & 26.0 & 2.7 & 32.0 & 3.2 & 34.0 & 0.67 & 143 \\
\hline Love \#4 & 26.0 & 3.1 & 44.0 & 4.6 & 38.0 & 0.50 & 198 \\
\hline Love $\# 5$ & 25.0 & 3,5 & 34.0 & 4.4 & 32.0 & 0.59 & 163 \\
\hline Love $\| 6$ & 9.0 & 0.5 & 38.0 & 6.1 & - & 0.51 & 246 \\
\hline Love $\# 7$ & 15.0 & 0.5 & 32.9 & 14.8 & - & 0.63 & 180 \\
\hline Miles \#1 & 8.0 & 1.1 & 37.7 & 15.2 & - & 0.53 & 220 \\
\hline Ponderosa $\# 1$ & 23.0 & 1,6 & 36.0 & 4.4 & - & 0.80 & 170 \\
\hline Ponderosa \#2 & 8.0 & 0.1 & 25.0 & 4.7 & - & 0.95 & 172 \\
\hline Ponderosa \#3 & 43.0 & 1.4 & 60.3 & 11.4 & - & 0.50 & 376 \\
\hline Ponderosa \#7 & - & - & 33.3 & 13.4 & - & 0.90 & 196 \\
\hline Ridgecrest & 31.0 & 3.0 & 43.0 & 7.1 & 27.0 & 0.70 & 250 \\
\hline Ridgecrest $\| 2$ & 16.0 & 0.7 & 33.3 & 7.6 & $=$ & 0.66 & 252 \\
\hline RIdgrcrest \#3 & 21.0 & 0.6 & 31.0 & 26.0 & - & 0.63 & 212 \\
\hline Ridgecrest $\# 4$ & 13.0 & 0.5 & 40.0 & 2.0 & - & 0.43 & 216 \\
\hline Sta. Barbara \|1 & 18.0 & 3.0 & 31.0 & 5.0 & 39.0 & 0.44 & 178 \\
\hline San Jose $\sharp 1$ & 14.0 & 2.2 & 133.0 & 30.5 & - & 0.30 & 803 \\
\hline San Jose $\not 2$ & 65.0 & 7.0 & 18.0 & 4.0 & 83.0 & 0.77 & 298 \\
\hline San Jose \#3 & 46.0 & 8.6 & 28.0 & 8.9 & - & 0.63 & 318 \\
\hline San Jose $\# 4$ & 15.0 & 2.3 & 22.0 & 9.5 & - & 0.59 & 280 \\
\hline San Jose $\# 7$ & 45.0 & 7.8 & 28.0 & 7.9 & - & 0.58 & 298 \\
\hline San Jose $\sharp 5$ & 18.0 & 1.6 & 20.0 & 12.2 & - & 0.85 & 649 \\
\hline San Jose $\# 6$ & 14.5 & 2.1 & 52.0 & 9.7 & - & 0.63 & 703 \\
\hline San Jose \#8 & 66.0 & 6.6 & 18.0 & 5.6 & - & 0.87 & 288 \\
\hline San Jose \#10 & 49.0 & 7.8 & 30.0 & 8.2 & - & 0.76 & 353 \\
\hline
\end{tabular}


Table 2c

cont.

\begin{tabular}{|c|c|c|c|c|c|c|c|}
\hline Name & $\mathrm{Na}$ & $\mathbf{k}$ & $\mathrm{Ca}$ & $\mathrm{Mg}$ & $\mathrm{S}_{2} \mathrm{O}_{2}$ & $\mathbf{F}$ & TDS \\
\hline Thomas \#1 & 44.0 & 2.7 & 53.0 & 5.5 & - & 0.41 & 298 \\
\hline Thomas $\# 2$ & 49.0 & 2.7 & 57.0 & 5.5 & - & 0.46 & 335 \\
\hline Thomas $\# 3$ & 45.0 & 2.7 & 56.0 & 5.9 & - & 0.50 & 318 \\
\hline Thomas \#4 & 59.0 & 3.1 & 62.0 & 5.7 & - & 0.48 & 390 \\
\hline Valley Gardens A & 52.0 & 6.0 & 25.0 & 8.1 & 62.0 & 0.99 & 305 \\
\hline Volandia \#1 & 18.0 & 2.3 & 34.0 & 6.2 & - & 0.41 & 195 \\
\hline Volandia \#2 & 17.0 & 2.3 & 36.0 & 9.0 & - & 0.42 & 170 \\
\hline Volandia \#3 & 18.0 & 2.7 & 36.0 & 5.6 & - & 0.41 & 195 \\
\hline Volandia $\| 4$ & 17.0 & 2.3 & 38.0 & 4.5 & - & 0.41 & 218 \\
\hline Volandia $\| 5$ & 17.0 & 2.7 & 35.0 & 5.2 & - & 0.41 & 203 \\
\hline Volandia $\# 6$ & 5.0 & 0.1 & 36.1 & 6.6 & - & 0.38 & 192 \\
\hline Volcano Cliffs & 44.0 & 7.0 & 6.0 & 18.0 & 70.0 & 0.87 & 268 \\
\hline Volcano cliffs $\# 2$ & 10.0 & 1.8 & 18.8 & 7.7 & - & 0.96 & 272 \\
\hline West Mesa \#1 & 114.0 & 1.0 & 2.0 & 1.0 & 23.0 & 0.96 & 348 \\
\hline West Mesa \|2 & 102.0 & 2.0 & 4.0 & 1.0 & 36.0 & 1.10 & 330 \\
\hline West Mesa \#3 & 35.0 & 0.5 & 6.3 & 2.8 & - & 1.38 & 316 \\
\hline West Mesa \#4 & 37.0 & 0.2 & 4.7 & 1.0 & - & 0.96 & 356 \\
\hline Yale \#1 & 23.7 & 4.8 & 34.2 & 6.5 & - & 0.49 & - \\
\hline Yale \#2 & 7.5 & 0.6 & 36.5 & 12.4 & - & 0.48 & 224 \\
\hline Yale \#3 & 6.0 & 0.9 & 31.7 & 6.7 & $=$ & 0.51 & 224 \\
\hline & 11.0 & 1.5 & 34.9 & 7.6 & - & 0.54 & 304 \\
\hline Valley Gardens B \|l & 54.1 & 6.1 & - & - & - & - & - \\
\hline Plant \#2 Lab & 43.0 & 8.0 & 22.0 & 6.0 & 77.0 & 0.58 & 305 \\
\hline Sunset Gardens $\varangle$ Atrisco & 31.7 & 4.0 & 36.0 & 5.1 & - & 1.05 & 270 \\
\hline Second \& Ranchitos & 15.0 & 2.3 & 35.7 & 4.3 & - & 0.57 & 808 \\
\hline
\end{tabular}


Table 2c

cont.

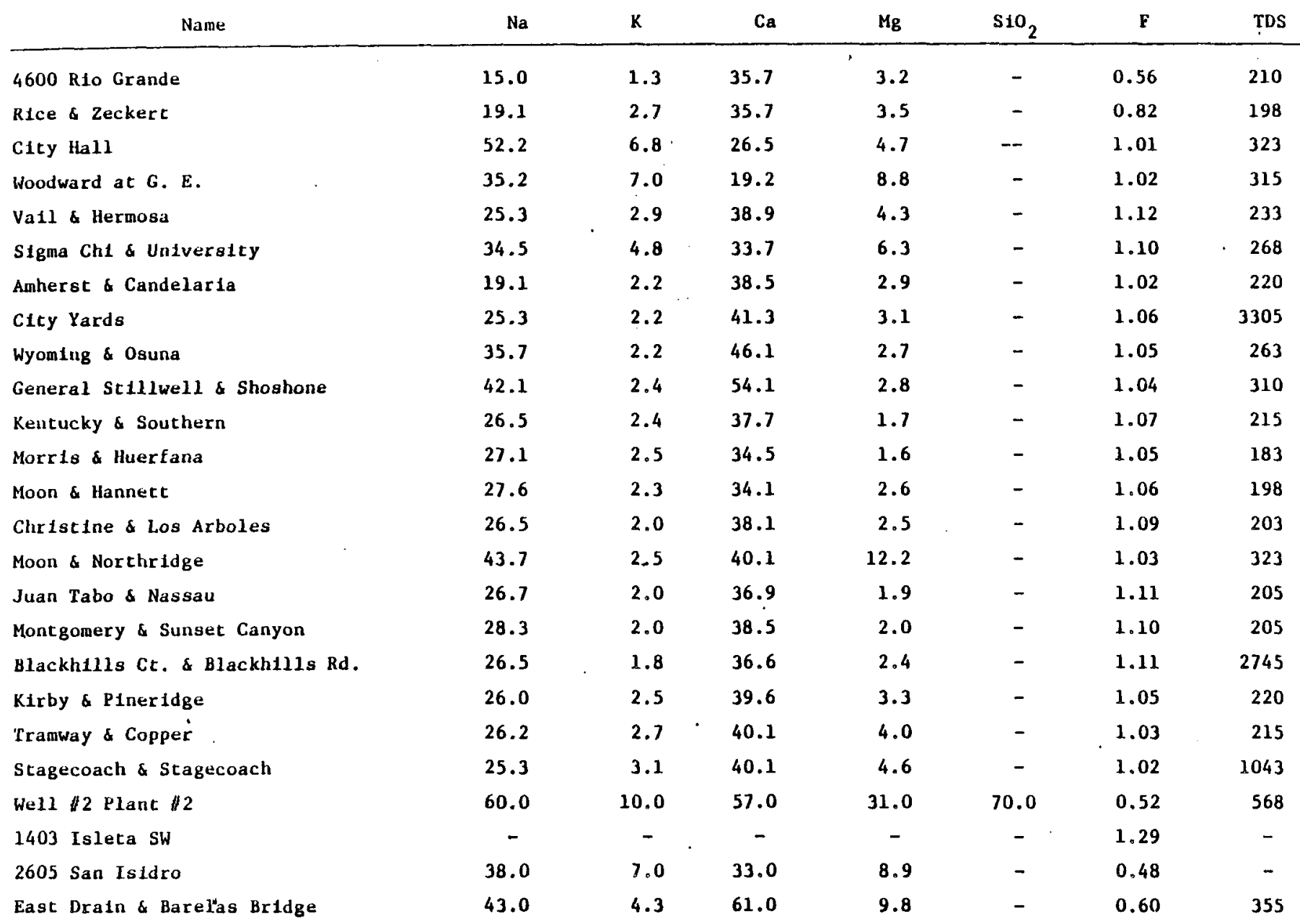


Table 2c

cont.

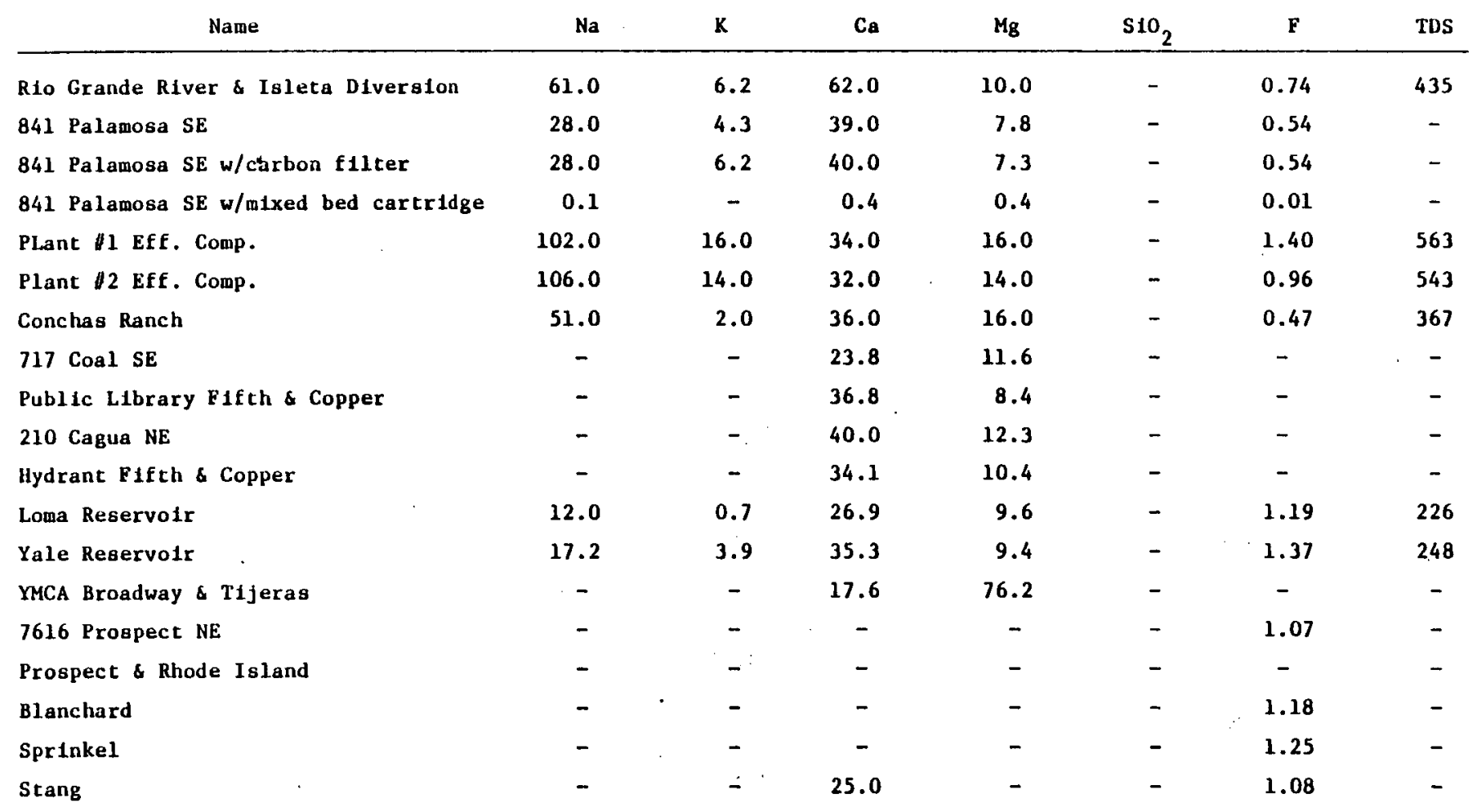


$\theta$

$\theta$ 